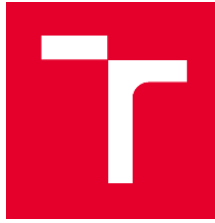

VYSOKÉ UČENÍ FAKULTA ELEKTROTECHNIKY

TECHNICKÉ A KOMUNIKAČNÍCH

V BRNĚ TECHNOLOGIÍ

\title{
Stabilita \\ elektrizační soustavy
}

Autor textu:

doc. Ing. Karel Máslo, CSc.

Únor 2021 


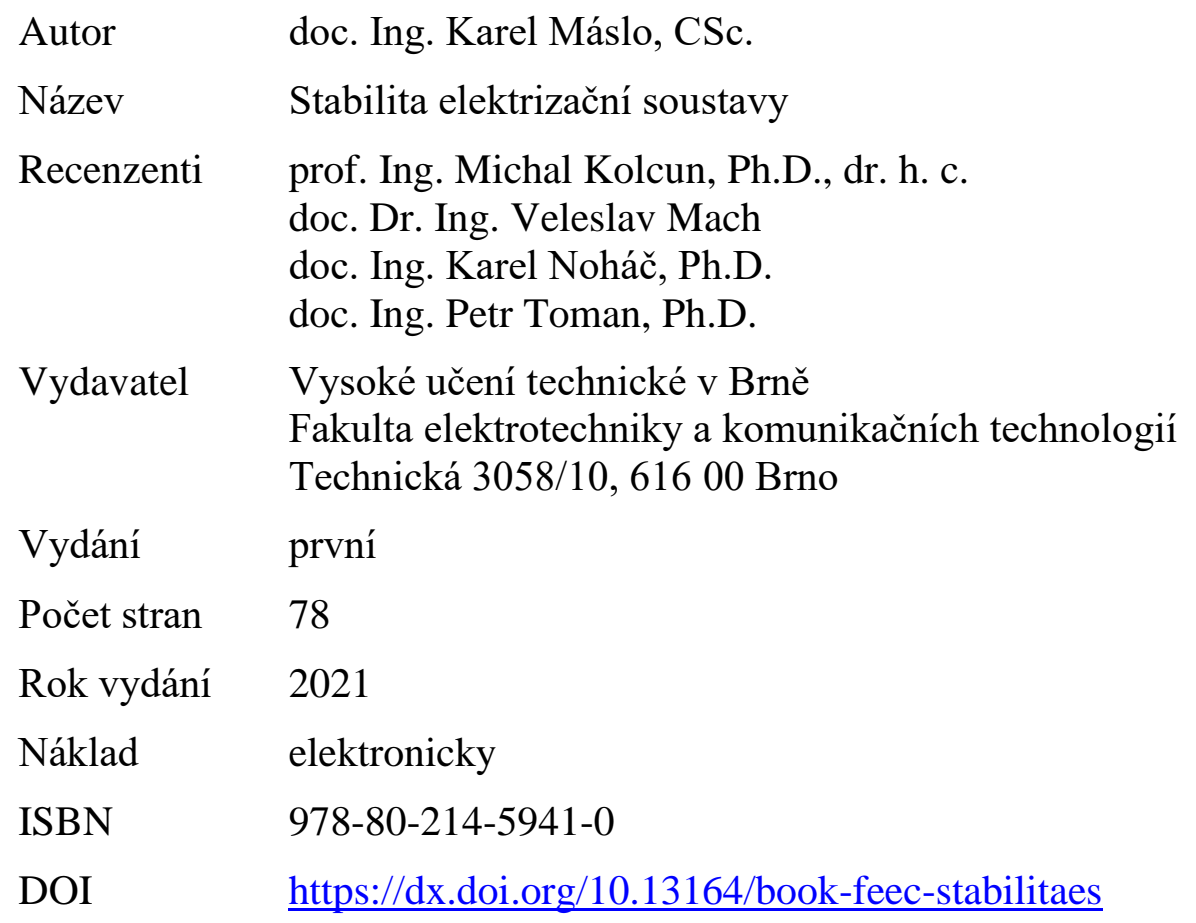

Publikace neprošla redakční úpravou. 


\section{Obsah}

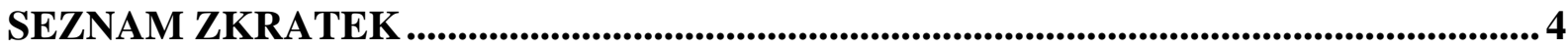

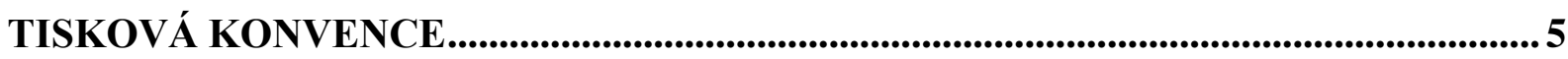

PǨEDPOKLADY PRO PRÁCI SE SKRIPTEM ........................................................6

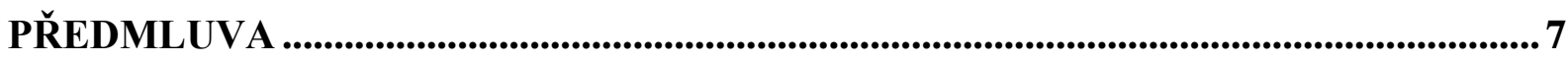

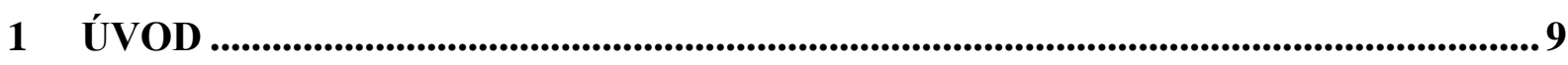

2 STABILITA ELEKTRIZAČNÍ SOUSTAVY ................................................................. 11

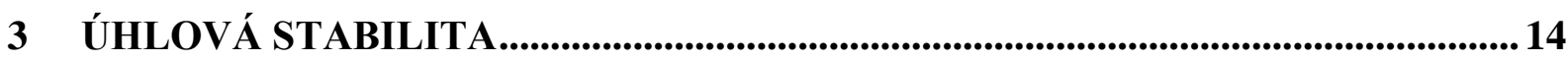

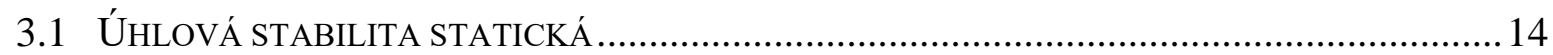

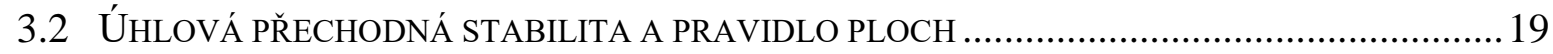

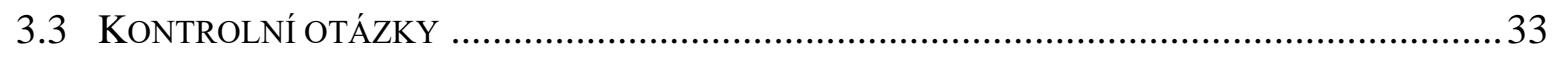

4 FREKVENČNÍ STABILITA ...................................................................................... 34

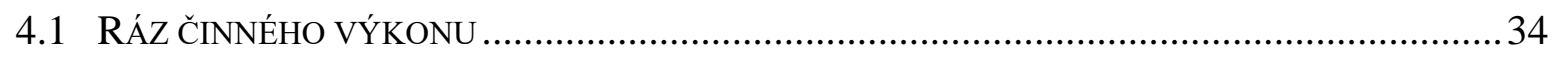

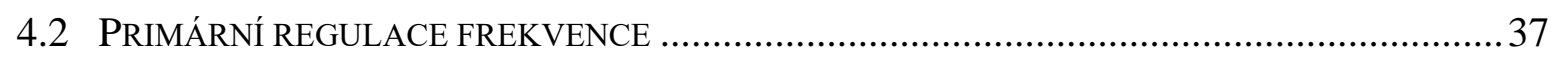

4.3 SEKUNDÁRNÍ REGULACE FREKVENCE A PŘEDÁVANÝCH VÝKONU゚ (F A P) .......................42

4.4 FREKVENČNÍ ODLEHČOVÁNÍ ZÁTĚŽE ................................................................ 45

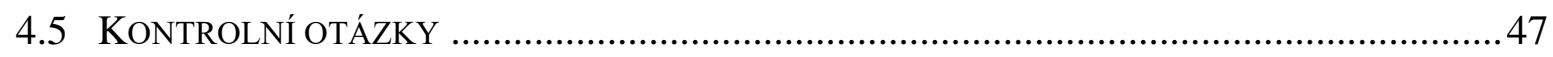

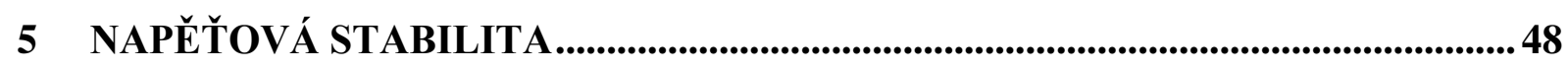

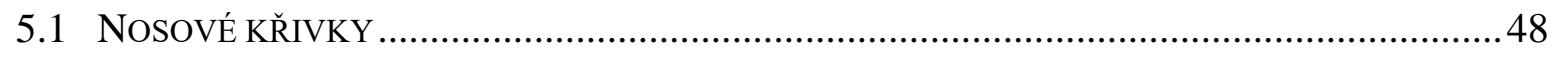

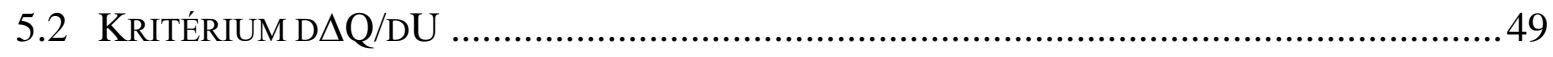

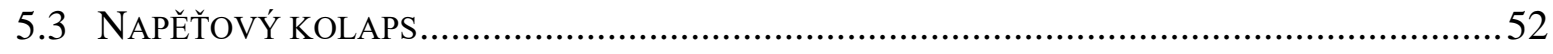

6 P̌̌ÍKLADY NARUŠENÍ STABILITY ES ................................................................5 57

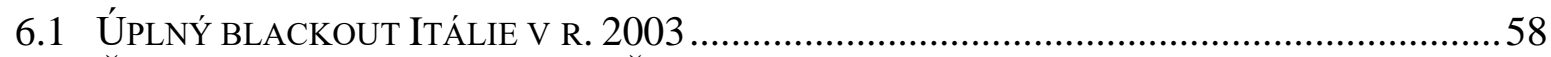

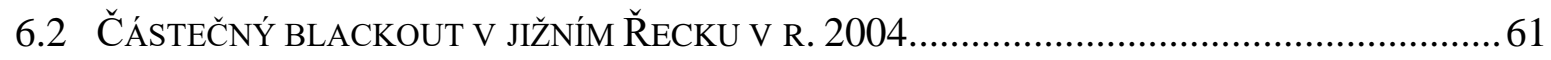

6.3 PŮSOBENÍ FREKVENČNÍHO ODLEHČOVÁNÍ V ANGLII V R. 2019 ..................................... 66

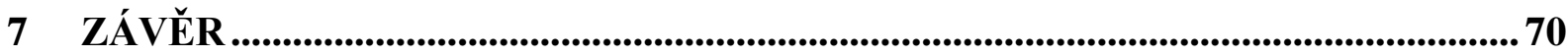

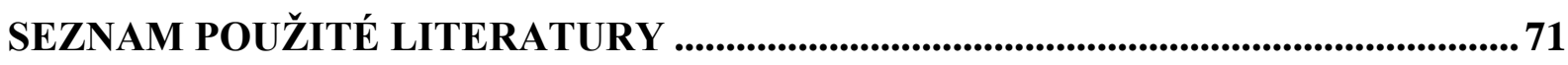

PŘÍLOHA 1: ZÁKLADY PRÁCE S PROGRAMEM MODES .......................................... 73

PŘÍLOHA 2: TřÍROZMĚRNÝ MODEL VSTUPNÍCH DAT ............................................ 77 


\section{Seznam zkratek}

\begin{tabular}{|c|c|}
\hline $\mathrm{ACE}$ & Area Control Error \\
\hline $\mathrm{CCT}$ & Critical Clearing Time \\
\hline $\mathrm{ES}$ & elektrizační soustava \\
\hline EU & Evropská unie \\
\hline $\mathrm{f} / \mathrm{P}$ & frekvence sítě a činné výkony \\
\hline FvE & fotovoltaické elektrárny \\
\hline HRT & hladinový regulátor transformátoru \\
\hline HVDC & High Voltage Direct Current - přenos stejnosměrným proudem \\
\hline IEC & International Electrotechnical Commission \\
\hline LFC & Load Frequency Control \\
\hline $\mathrm{NN}$ & nízké napětí \\
\hline OZE & obnovitelné zdroje energie \\
\hline PPC & paroplynový cyklus \\
\hline PS & přenosová soustava \\
\hline $\mathrm{U} / \mathrm{Q}$ & napětí ${ }^{1}$ a jalové výkony \\
\hline UPFC & Unified Power Flow Controller \\
\hline $\mathrm{VN}$ & vysoké napětí \\
\hline $\mathrm{VtE}$ & větrné elektrárny \\
\hline VUT & Vysoké učení technické v Brně \\
\hline VVN & velmi vysoké napětí \\
\hline WSCC & Western System Coordinating Council \\
\hline ZČU & Západočeská univerzita v Plzni \\
\hline
\end{tabular}

${ }^{1}$ Pojem napětí se bude používat zjednodušeně pro jeho amplitudu (u stř́davé síti má napětí i frekvenci) 


\section{Tisková konvence}

Pro poměrné hodnoty je v textu použita kurzíva $X$ nebo malá písmena $\mathrm{x}$.

Pro fázory a komplexní čísla je použito podtržení $\underline{X}$.

Pro proměnnou v Laplaceově transformaci malé písmeno $\mathrm{p}$.

Výpisy souborů jsou ve fontu Courier New a ohraničeny rámečkem.

Jména typových parametrů dynamických modelů a objektů modelu jsou ve fontu Courier New. Č́slem na žlutém pozadí (1.1) jsou uvedeny odkazy do Př́ílohy $1 \mathrm{~s}$ popisem pracovního postupu. Jako oddělovač desetinného místa se v textu i grafech používá desetinná tečka. 


\section{Předpoklady pro práci se skriptem}

Předpokladem pro využívání tohoto skripta jsou znalosti:

- principů operátorového počtu (Laplaceova transformace),

- základů přechodných dějů v ES,

- základního přehledu o modelování zařízení ES (elektrárny) a přenosových sítí,

- regulačních pochodů (základy primární a sekundární regulace U/Q a f/P),

- složkových soustav pro modelování nesymetrických zkratů,

- pro simulaci dynamických průběhů základní dovednosti s programem MODES (viz [1]) jako je ukládání variant parametrů výpočtu, variací chodů sítě a modifikací dynamických modelů bloků a uzlů, rovněž ukládání nově vzniklých př́ípadů a nakonec i uložení projektů pod novými jmény; potřebné pracovní postupy jsou v Příloze 1 a datový model je blíže popsán v Př́íloze 2. 


\section{Předmluva}

Predložené skriptá Stabilita elektrizačnej sústavy sú venované hlavne riešeným príkladom z oblasti uhlovej, frekvenčnej a napätovej stability s využitím programu MODES, ktorého autorom je samotný autor skrípt doc. Maslo. Riešené príklady sú vhodne navrhnuté pre pochopenie zložitej problematiky - stability elektrizačných sústav. Výsledky riešených príkladov v programe MODES sú prezentované v grafickej podobe, čo potvrdzujú správnost' riešenia. Vhodným doplnkom skrípt je kapitola č. 6 - príklady narušenia stability elektrizačnej sústavy, kde na konkrétnych situáciách úplných alebo čiastočných blackoutov v Európe sú analyzované jednotlivé poruchy. Skriptá sú vhodné ako doplnková literatúra pre inžinierske štúdium v odbore Elektroenergetika, prípadne v iných príbuzných odboroch. Skriptá môžu byt' vhodnou študijnou literatúrou aj pre doktorandské štúdium a odborníkov z praxe pracujúcich v elektroenergetike.

V Košiciach 08. 12. 2020

prof. Michal Kolcun

Autor je dlouholetý pracovník venergetice a má bohaté zkušenosti s provozem přenosových soustav. Kromě celé řady publikací vtělil své znalosti i do návrhu sítového simulátoru MODES. Data v něm obsažená vycházela $\mathrm{z}$ bývalé československé energetiky a jsou dále doplňována např. o alternativní zdroje energie. Program MODES tak umožnil nejen autorovi, ale i celé řadě pracovníků firem a univerzit provádět rychleji a efektivně různé analýzy přechodných dějů v elektrizační soustavě.

Předložený učební text je snaha autora, jako nově jmenovaného docenta, předat své zkušenosti a znalosti budoucí generaci energetiků, kteří nyní studují na fakultách. Rozsah a hloubka sdílených poznatků je značná, byt’ se věnuje ,pouze“ stabilitě elektrizační soustavy.

Studenti se mohou dozvědět, co se skrývá pod pojmem stabilita, uvědomit si, co vše zahrnují přechodné děje v elektrotechnice a na konkrétních př́íladech si pomoci simulací představit, jak se různé scénáře událostí projeví v elektrizační soustavě.

Kapitola Frekvenční stabilita třeba na příkladech ukazuje funkci primární a sekundární regulace. Závěrečná kapitola pak analyzuje reálné ztráty stability ve světě v letech 2003 až 2019. Vše je pak doplněno celou řadou citovaných publikací, což umožní další studium.

Přesto, že publikace má jen 70 stran, není to čtení na jeden večer. Každou stránku, každý př́klad je nutno dlouho promýšlet a pomocí programu MODES analyzovat.

Nebojím se říci, že díky autorovi tady zůstane kvalitní materiál, ze kterého budou moci čerpat poznatky ještě další generace elektroenergetiků.

V Ostravě 24. 12. 2020

Veleslav Mach 
Je zřejmé, že autor dokázal zcela plnohodnotně využít své celoživotní zkušenosti v specifické úzké odborné oblasti, kterou se intenzivně zabýval. To má za důsledek nesmírně precizní propracování tématu jak do hloubky, tak do všech souvislostí, které navíc důsledně dokumentuje potřebnými studijními odkazy. Př́nos skripta je umocněn tím, že touto specifickou úzkou problematikou se v poslední době učební podklady věnovaly spíše částečně, nebo jen okrajově.

Autor vždy plynule přechází od zjednodušených teoretických matematických a modelových popisů $\mathrm{k}$ plnohodnotným praktickým konceptům a připravuje tak čtenáře na obvyklé reálné technické problémy. Publikace tak je nejen vhodným rozšiřujícím materiálem pro oborové studenty, ale i prostředkem pro pracovní adaptaci v tomto oboru a taktéž může být osvěžujícím teoretickým doplňkem pro čtenáře s rozsáhlými praktickými zkušenostmi. Za př́kladný lze považovat i přístup k postupnému vysvětlování stále komplikovanějších variant systémových topologií $\mathrm{s}$ postupným přidáváním komponent a variant sekvencí reakcí subsystémů v časovém sledu.

Skriptum obsahuje i některé dosud ve studijních pramenech nezveřejněné postupy, kde jako nejvýraznější se ukazuje autorova vlastní metodika určení mezního času vypínání poruchy lineární aproximací pouze ze dvou reprezentativních simulačních řešení, tedy bez nutnosti postup iteračně mnohokráte opakovat. Pro praktického čtenáře je skriptum možné vnímat i jako soubor demonstračních př́kladů aplikovatelnosti autorova komplexního analytického simulačního nástroje MODES.

V Plzni 15. 1. 2021

Karel Noháč

Skriptum vzniklo jako učební text předmětu "Přechodné jevy" pro studenty magisterských studijních programů "Elektroenergetika" a "Elektroenergetika a komunikační technologie" vyučovaných na Fakultě elektrotechniky a komunikačních technologií VUT v Brně.

Skriptum významně rozšiřuje dostupné texty vysvětlující základy problematiky stability elektrizační soustavy z druhé poloviny minulého století a dává tak studentům aktuální pohled na možnosti výpočtu stability, přidává nové postupy a vše doplňuje praktickými př́klady. Zajímavé bezesporu jsou také př́íklady reálných událostí narušení stability ES.

V dané oblasti se v rámci České republiky jedná o poměrně unikátní počin, nebot' takto aktuálně a prakticky nebyla problematika stability elektrizační soustavy $\mathrm{v}$ tomto století publikována.

Jsem přesvědčen, že tento studijní materiál nalezne uplatnění ve výuce přechodných jevů nejen v rámci České republiky.

V Brně 31. 1. 2021

Petr Toman 


\section{1 Úvod}

Podle definice uvedené v Kodexu přenosové soustavy (PS) [2] tvoří elektrizační soustava (ES) vzájemně propojený soubor zařízení pro výrobu, přenos, transformaci a distribuci elektřiny, včetně elektrických přípojek a přímých vedení, a systémů měřicí, ochranné, rrídicí, zabezpečovací, informační a telekomunikační techniky.

V Kodexu PS je také definována stabilita provozu jako schopnost soustavy udržet rovnovážný stav během normálního provozu i po přechodných dějích způsobených vnějšími vlivy, dispečerským ř́zením i poruchovými výpadky zařízení.

Společná pracovní skupina IEEE a CIGRE [3] definovala stabilitu ES zhruba takto: jestliže dojde $\mathrm{v}$ soustavě k rozruchu, musí se soustava vrátit do rovnovážného stavu s veličinami $\mathrm{v}$ dovolených mezích a soustava jako celek zůstane nedotčena.

Podle příciny můžeme rozruchy specifikovat takto:

- změny provozního charakteru - proměnlivost odebíraného nebo dodávaného výkonu, plánované změny topologie sítě (např. vypínání nebo zapínání vedení),

- poruchy zařízení způsobené skrytými vadami nebo zrychleným stárnutím (výpadky elektrárenských bloků a vedení),

- poruchy způsobené klimatickými vlivy jako údery blesku, silným větrem, vysokou teplotou (zkraty),

- poruchy způsobené lidskou neúmyslnou chybou,

- vlivy fungování trhu s elektřinou,

- záměrné útoky na zařízení ES,

- geomagnetické bouře.

Běžné změny odebíraného výkonu podle denního diagramu zatížení nezpůsobí narušení stability ES, protože provozovatelé přenosových soustav udržují výkonovou rovnováhu $\mathrm{v}$ reálném čase (podrobněji viz [4] str. 1). Rovněž běžné změny dodávaného výkonu v rámci plánovaného provozu i náhodné poruchové výpadky zdrojů obvykle neohrožují stabilitu, protože na pokrytí výpadků výkonu slouží rezerva primární regulace frekvence. Určité riziko může představovat změna výkonu fotovoltaických elektráren na velkém území (způsobená např̀. zatměním slunce v r. 2015 - podrobnosti jsou v článku [5]) nebo změna výkonu větrných elektráren při přechodu větrné fronty. Provozovatelé soustav proto sledují predikce výrob z těchto obnovitelných zdrojů energie a mají připravena nápravná opatření. S decentralizovanými zdroji je spojeno další riziko, tzv. problém $50.2 \mathrm{~Hz}$. Zdroje připojované podle starých norem měly frekvenční ochrany, které je vypínaly již při frekvenci 49.8 a $50.2 \mathrm{~Hz}$. Při náhodném vybočení frekvence sítě z těchto mezí a velké výrobě na úrovni celého synchronního propojení kontinentální Evropy by mohl vzniknout výkonový defícit přesahující velikost sumární rezervy pro primární regulaci frekvence (podrobněji viz [6]). Následný nekontrolovaný pokles frekvence způsobí frekvenční odlehčování zátěže a v nejhorším případě blackout tím, že se odpojí i zdroje.

Výpadky zařízení a zkraty představují nejtěžší poruchy v soustavě a jejich vliv je proto pečlivě analyzován z několika hledisek. U výpadků zařízení se kontrolují přetížení a dodržení napět'ových poměrů. Jako metoda se používá statický výpočet chodů sítě a proces se nazývá také kontingenční analýzou, která je základním prostředkem pro kontrolu dodržování bezpečnostního kritéria N-1. Toto kritérium je podle [7] definováno jako pravidlo, podle něhož jsou prvky, které $\mathrm{v}$ regulační oblasti provozovatele přenosové soustavy zůstanou $\mathrm{v}$ provozu po vzniku kontingence, schopny zvládnout novou provozní situaci bez překročení limitů provozní bezpečnosti. 
Mezi tyto limity lze zahrnout přinejmenším:

a) napětové limity, které jsou jasně stanoveny dovoleným rozsahem napětí,

b) limity minimálního zkratového proudu pro řádný provoz ochran,

c) limity maximálního zkratového proudu pro nepřekročení zkratové odolnosti zařízení ${ }^{1}$,

d) limity proudu z hlediska zatížitelnosti neboli ampacity.

Ampacita (proudová zatížitelnost) přitom není konstantní parametr, ale je omezena maximální dovolenou provozní teplotou vodiče a je tudíž závislá na klimatických vlivech (teplotě okolí, rychlosti větru a slunečním záření - podobněji viz např. [8]).

Velikost zkratových proudů se kontroluje statickým výpočtem zpravidla podle norem (např. [9]). Zkraty ale také tvoří těžiště výpočtů úhlové stability, kdy se dynamickým výpočtem kontroluje, jestli mezní doba trvání zkratu není kratší než skutečná doba vypnutí zkratu (daná činností ochran a časem vypínače). Posuzováním úhlové stability se zabývá kapitola 3.

Fungování trhu s elektřinou ovlivňuje provoz ES v řadě aspektů. Frekvenční stabilitu ovlivňují změny výkonu elektráren $\mathrm{v}$ hodinových střizích obchodních intervalů, kdy zdroje najíždějí na nové diagramové body (platné na následující obchodní hodinu) nebo také vypínání přečerpávacích vodních elektráren z režimu čerpání. Vznikají tak tzv. deterministické odchylky frekvence, které mohou v kontinentálním evropském propojení dosahovat hodnot až k hranici $\pm 100 \mathrm{mHz}$ nebo i více (podrobněji viz [10]).

Lidské chyby při obsluze zařízení $\mathrm{v}$ ES patří $\mathrm{k}$ častým př́icinám poruch, které mohou vést až k ztrátě stability. K tomu, aby se zabránilo chybám a jejich následkům, slouží technická opatření, výcvik dispečerů a obsluhy rozvoden, důsledné dodržování kritéria N-1 a připravené plány obrany proti šíření poruch (viz Kodex PS V. [11]).

Stabilitu malých kyvi̊ mohou ohrozit přenosy výkonů na velké vzdálenosti přes oslabené přenosové profily. V takové situaci narůstá riziko netlumených systémových kyvů (o frekvenci $0.15-0.6 \mathrm{~Hz}$ ). K takovým př́padům už v synchronním propojení kontinentální Evropy došlo, naposledy 1. 12. 2016, kdy během velkých přenosů ze Španělska do Francie došlo k oslabení přenosového profilu výpadkem vedení (viz zpráva [12]).

$\mathrm{K}$ extrémním prŕíkladům útoků na zařízení ES docházelo během války v Jugoslávii v roce 1991 (zničení rozvodny 400 kV Ernestinovo), což vedlo k rozdělení propojení kontinentální Evropy na dvě synchronní zóny. Trvalo dlouhých třináct let, než se podařilo odstranit následky války a obě synchronní zóny 10. 10. 2004 znovu propojit. Útok může být i kybernetický, jako bylo „narušení systému“ - nejspíše přerušení spojení mezi rozvodnami, způsobené údajně počítačovým virem na západě Ukrajiny 23. 12. 2015. Blackout, který postihl na několik hodin část území zásobované distribuční společností Прикарпаттяобленерго (Prikarpattjaobleněrgo), měl pravděpodobně příčinu $\mathrm{v}$ narušení systémů měřicí, rrídicí, zabezpečovací, informační a telekomunikační techniky.

Geomagnetické bouře, způsobené výrony plazmatu ze Slunce, vyvolávají poruchy geomagnetického pole Země, které indukuje do přenosových vedení proudy o velmi nízké frekvenci. Tyto proudy se uzavírají přes uzemněné středy vinutí transformátorů a mohou způsobit jejich přehřívání. Výskyt prakticky stejnosměrné složky magnetizačního proudu může způsobit přesycování magnetických jader transformátorů a nárůst vyšších harmonických, které mohou nepř́źznivě ovlivňovat činnost ochran. Proudy o nízké frekvenci přetěžují sériové kompenzátory. Tato rizika jsou větší v soustavách $\mathrm{s}$ dlouhými přenosovými vedeními v severních zeměpisných šiřkách. V našich geografických poměrech je riziko malé a skriptum se těmito ději nezabývá.

Autor by rád poděkoval recenzentům a Milanu Bělíkovi ze ZČU v Plzni, Branislavu Bátorovi a Janu Koudelkovi z VUT v Brně za pomoc a za podnětné připomínky, které vedly k vylepšení skripta po stránce jazykové, odborné i pedagogické.

\footnotetext{
${ }^{1}$ Podle standardů IEC se tímto rozumí hodnoty jmenovitého výdržného proudu a jmenovitého vypínacího proudu.
} 


\section{Stabilita elektrizační soustavy}

Základy pro vyšetřování stability položil už v r. 1892 ruský matematik A. M. Ljapunov svou publikací Obecná úvaha o stabilnosti pohybu (později publikována např. v [13]). V elektrizačních soustavách se začaly problémy se stabilitou řešit v souvislosti $\mathrm{s}$ výstavbou a provozem dlouhých vedení od r. 1920. Objevují se první publikace o stabilitě (viz [14]-[17]).

U nás dostupný překlad práce $\mathrm{V}$. A. Venikova [18] rozlišoval přechodné děje:

1. při malých odchylkách od ustáleného stavu a malých změnách otáček,

2. způsobené velkými rozruchy při malých změnách otáček,

3. způsobené velkými rozruchy při velkých změnách otáček.

První př́ípad řeší tzv. statická stabilita - nazývaná také stabilita malých kyvů. Vyšetřuje se nejčastěji ve frekvenční oblasti na linearizovaném systému rovnic, kdy se hledají kořeny charakteristických rovnic a pokud jsou jejich reálné části záporné, soustava je stabilní a přechodné jevy se ustálí. Postup řešení je popsán v řadě publikací ([19]-[22]). Pro tento typ stability je př́iznačné, že je již vlastností samotné soustavy a není vyvolána nějakou inicializační poruchou tzv. rozruchem (v angličtině „,disturbance“, v ruštině „,возмущение (vozmuščenije)“) jako je tomu u dalších dvou typů přechodných dějů. Rozruchem jsou míněny poruchy typu zkratů a/nebo výpadků zařízení, ale i manipulace v síti, změny zatížení nebo výkonu zdrojů. Obecně řečeno soustava je stabilní, pokud po skončení přechodných dějů nastane ustálený stav.

Jelikož ES představuje složitý systém, který je vystaven neustálým změnám zvnějšku i zevnitř, je užitečné z hlediska zkoumání odolnosti soustavy proti rozruchům rozdělit stabilitu do několika dílčích problémů. To při analýze umožňuje přijmout určité zjednodušující předpoklady pro reprezentaci soustavy a pro využití odpovídajících analytických metod. Následující obrázek ukazuje základní rozdělení typu stability.

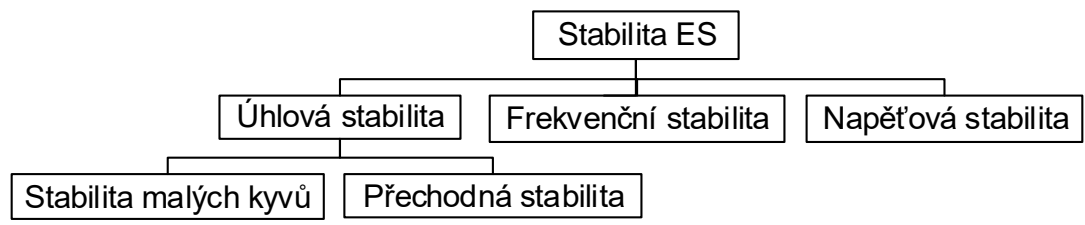

Obr. 2-1 Rozdělení typů stability ES (zjednodušeně podle [3])

Úhlová stabilita souvisí s pohybem rotorů synchronních strojů, které se nejvíce používají jako zdroje pro výrobu elektřiny. Vztahuje se tedy na schopnost synchronních strojů zůstávat ve vzájemném synchronismu. Vzájemným synchronismem se rozumí podle [23] schopnost udržet konstantní úhlové rozdíly mezi rotory jednotlivých synchronních strojů v ustáleném stavu a samostatně obnovit takovýto stav po rozruchu.

To souvisí se schopností udržet rovnováhu mezi elektrickým momentem generátoru a mechanickým momentem poháněcího stroje, kterým bývá nejčastěji turbína. Úhlová stabilita se tedy týká elektromechanických přechodných dějů. Úhlovou stabilitu můžeme dále rozdělit na stabilitu malých kyvů a přechodnou stabilitu (z angl. „transient stability“). Zde není jednotná terminologie. Starší literatura [18] používala rozdílené pojmy stabilnost v malém (statická stabilita) a stabilnost ve velkém (dynamická stabilita).

Rovněž učebnice [19] používala termíny statická a dynamická stabilita, přičemž statická stabilita se týkala tzv. malých kyvů a dynamická náhlých změn (spínacích pochodů, nárazů zatížení a především zkratů). V dalším výkladu budeme v souladu s doporučením [3] používat pojem přechodná stabilita, i když u nás není rozšířen.

Pro řešení obou typů úhlové stability se používají odlišné metody. Zatímco stabilitu malých kyvů lze řešit ve frekvenční oblasti (hledáním kořenů charakteristických rovnic soustavy lineárních diferenciálních rovnic - viz [19] str. 272), u přechodné stability nelze předpoklad 
linearity přijmout a řeší se v časové oblasti. Použivají se většinou tzv. sítové simulátory, které spočítají časové průběhy fyzikálních veličin.

Alternativu tvoří metody nevyžadující simulační výpočty na dynamickém modelu. Příkladem je použití př́ímé Ljapunovovy metody, popsané podrobněji v učebnici [19] na str. 256. Metodu lze uplatnit i pro rozsáhlejší systémy, ale většinou se provádí nějaké zjednodušení složité soustavy (např. na jeden stroj pracující do tvrdé sítě nebo na dvoustrojovou soustavu).

V obou př́padech úhlové stability se jedná o krátkodobé děje, které stačí vyšetřovat do 10 sekund. Proto se také nazývají jako krátkodobá dynamika. U přechodné stability se dokonce vystačí s dobou kratší, pak se hovoří o stabilitě prvního kyvu (angl. „first swing stability“).

Napětová a frekvenční stabilita souvisí se schopností soustavy udržet rovnováhu činných a jalových výkonů (mezi výrobou a spotřebou) a tudíž i stabilní frekvenci a napětí po rozruchu z daného výchozího stavu.

Při rozlišení pojmů úhlové a napět'ové stability se také uvádí, že úhlová stabilita souvisí především se synchronními stroji, zatímco napětová stabilita úzce souvisí s chováním zátěže.

Stabilita ES úzce souvisí s přechodnými ději. Rozdělení přechodných dějů symbolicky ukazuje Obr. 2-2, kde na vodorovné ose je vynesen časový rozsah, v kterém děje vyšetřujeme. Ve spodní části obrázku v plných obdélnících jsou naznačena zařízení, která tyto děje ovlivňují, a tudíž musí být zahrnuty do matematického modelu. Ve střední části v tečkovaných obdélnících jsou některé prríčiny (rozruchy), které způsobují přechodné děje. Mohou mít jak poruchový (zkraty nebo výpadky zařízení), tak provozní charakter (změny zatížení nebo zásahy obsluhy).

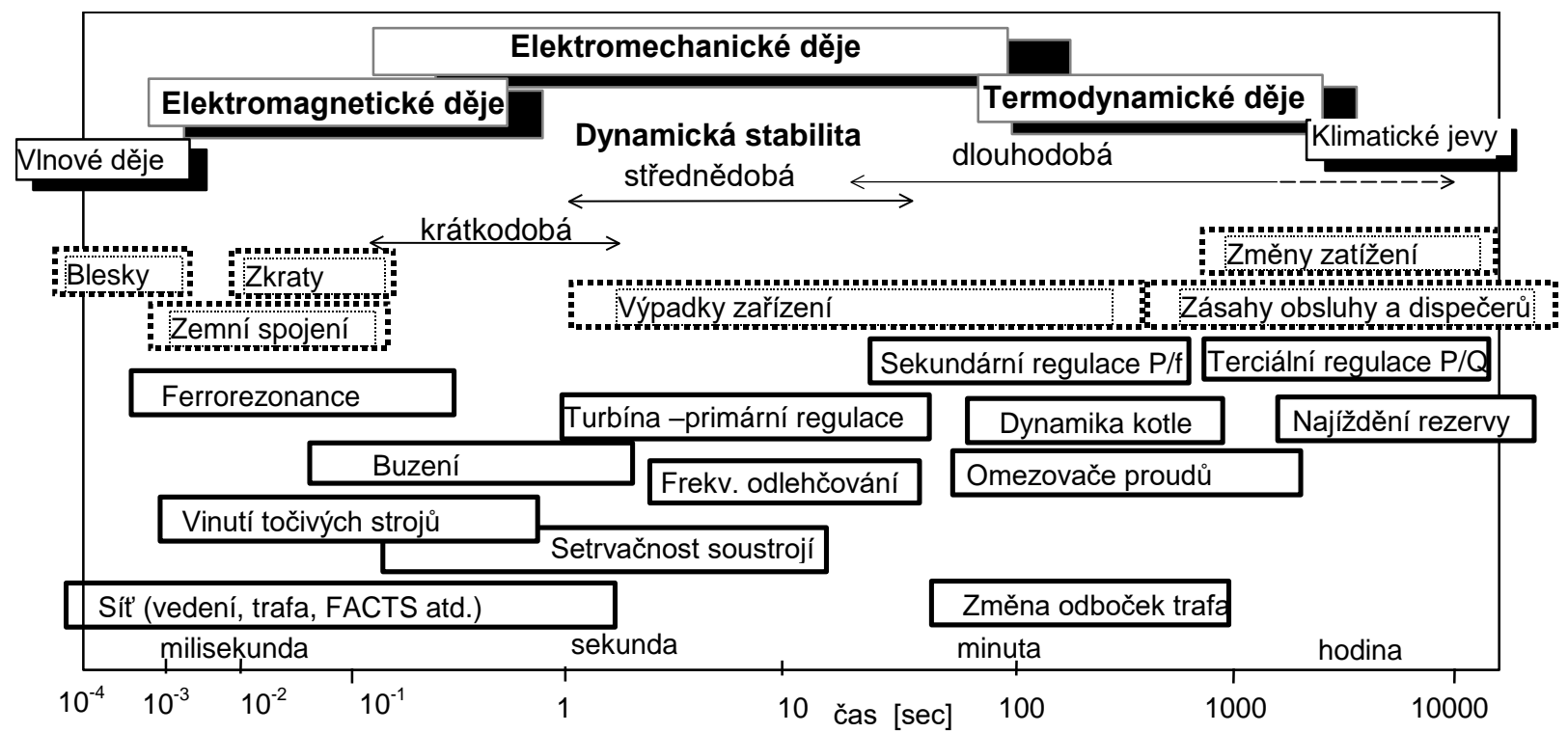

Obr. 2-2 Časový rozsah přechodných dějů v ES (přejato z [25] a upraveno)

Vhorní části obrázku je základní rozdělení na vlnové, elektromagnetické, elektromechanické a termodynamické děje. Nejrychlejší jsou vlnové přechodné děje, trvající mikrosekundy až milisekundy. Průběh změn provozních veličin v těchto dějích je tak rychlý, že nelze zanedbat rychlost šírení elektromagnetických vln v jednotlivých prvcích ES a tyto prvky je nutno nahrazovat modely s rozprostřenými parametry. Matematický model těchto dějů vede $\mathrm{k}$ řešení parciálních diferenciálních rovnic.

Elektromagnetické přechodné děje trvají od milisekund do několika desetin sekundy. Lze u nich zanedbat šíření elektromagnetických vln v prvcích ES a pro všechny prvky použít model se soustředěnými parametry. Rovněž lze zanedbat změny otáček točivých strojů a jejich úhlové rychlosti považovat za konstantní. To umožňuje nahlížet na ES jako na čistě elektrický systém. V matematickém popisu to znamená přejít od parciálních diferenciálních rovnic k obyčejným diferenciálním rovnicím s časem jako jedinou nezávislou proměnnou. 
Toto skriptum je zaměřeno na elektromechanické přechodné děje, jejichž doba trvání se mění v širokých mezích od několika sekund až po několik minut. Tyto děje lze dále členit na krátkodobou, střednědobou a dlouhodobou dynamiku. Toto členění je užitečné z toho důvodu, že různé typy výpočtů vyžadují i různé typy modelů zařízení.

Při krátkodobé dynamice (do několika sekund) vyšetřujeme vliv poruch typu zkratů na stabilitu synchronních a asynchronních strojů (úhlovou stabilitu). Při těchto výpočtech vystačíme s modelem pasivní sítě, s modely točivých strojů a jejich budicích systémů. Za předpokladu, že zkraty trvají několik desetin sekundy, lze uvažovat zjednodušeně konstantní výkon turbíny, takže turbína modelována být nemusí.

Stř̌ednědobá dynamika (do několika desítek sekund) souvisí s činností primární regulace frekvence a regulace otáček po vzniku deficitu činného výkonu po výpadcích bloků nebo přechodem části ES do ostrovního režimu (hrozba frekvenčního kolapsu). Oproti krátkodobé dynamice je nutno model rozšíriit o primární pohony a jejich regulaci. Př́ poklesech frekvence pod $49 \mathrm{~Hz}$ je nutno vzít v úvahu i činnost frekvenčního odlehčování zátěže.

Dlouhodobá dynamika (od několika minut až po hodiny) souvisí jednak s činností sekundární regulace f/P (LFC z angl. „load frequency control“) při udržování výkonové rovnováhy a jednak s činností sekundární regulace U/Q (automatické regulace napětí - ARN), změnou odboček transformátorů a omezovačů proudů regulátorů buzení generátorů po vzniku deficitu jalového výkonu (hrozba napět'ového kolapsu).

Pokud výpočet dynamiky prodloužíme na několik hodin, je nutné vzít v úvahu i změny zatížení v rámci denního diagramu, proměnnou výrobu fotovoltaických elektráren, změnu skladby a nasazení výrobních bloků. Takové výpočty už přesahují rámec dynamické stability a zabývá se jimi tzv. adekvátnost, jako schopnost soustavy pokrývat zatížení.

Následující text je organizován takto. Nejprve je pro každý typ stability proveden teoretický rozbor. Pak následuje jednoduchý př́klad, který je převzat z předchozí literatury. Odpovídající výpočet je proveden i sít’ovým simulátorem MODES, který umožnuje graficky zobrazit průběh přechodných dějů a lépe tak seznámit čtenáře s dynamikou ES. Simulátor MODES lze pro účely výuky a výzkumu stáhnout z webu www.modesinfo.com.

Projekty s popisem testovacích soustav a vstupními daty jsou dostupné na webových stránkách https://www.ueen.fekt.vut.cz/testovaci-modely-stabilita-es. Zde jsou uloženy výchozí projekty UHL_STA, FRK_STAB a NAP_STAB, které obsahují výchozí případ pro řešení prríkladů z tohoto skripta. Př́i řešení př́kladů lze podle návodu vytvářet vlastní prŕípady a ukládat je pod novými jmény a s doprovodným popisem, který charakterizuje řešený př́ípad. Na konci práce je vhodné si výchozí projekt s nově vytvořenými př́pady uložit pod novým jménem a opět s upřesňujícím popisem. Předpokládá se, že uživatel zachová výchozí vstupní data a tvoří si své variace, varianty a modifikace. Původní projekt tak zůstane zachován a nově uložený projekt je připraven na další použití.

V textu skripta není na ukládání případů a projektů upozorněno, ale je dobré tuto praxi dodržovat. Návrh jmen nově vytvořených př́padů a projekti̊ a jejich popis je ponechán na fantazii a pečlivosti uživatele. Uživatelské rozhraní MODMAN umožnuje také definovat (v menu Volby) i jméno uživatele, čímž se identita nových projektů a prrípadů ještě více zpřesní.

$\mathrm{V}$ popisu řešení př́ikladu na dynamickém modelu jsou $\mathrm{v}$ závorkách (pomocí čísla na žlutém pozadí) uvedeny odkazy na detailní postupy z Př́lohy 1 . Pokud čtenář ještě se simulátorem MODES nepracoval, doporučuje se seznámit se datovým modelem, stručně popsaným v Př́loze 2. 


\section{3 Úhlová stabilita}

Úhlovou stabilitu lze rozdělit na statickou (pomalé změny) a přechodnou (rychlé změny).

\section{1 Úhlová stabilita statická}

Úhlovou stabilitu si můžeme vysvětlit na jednostrojovém modelu podle Obr. 3.1-1:

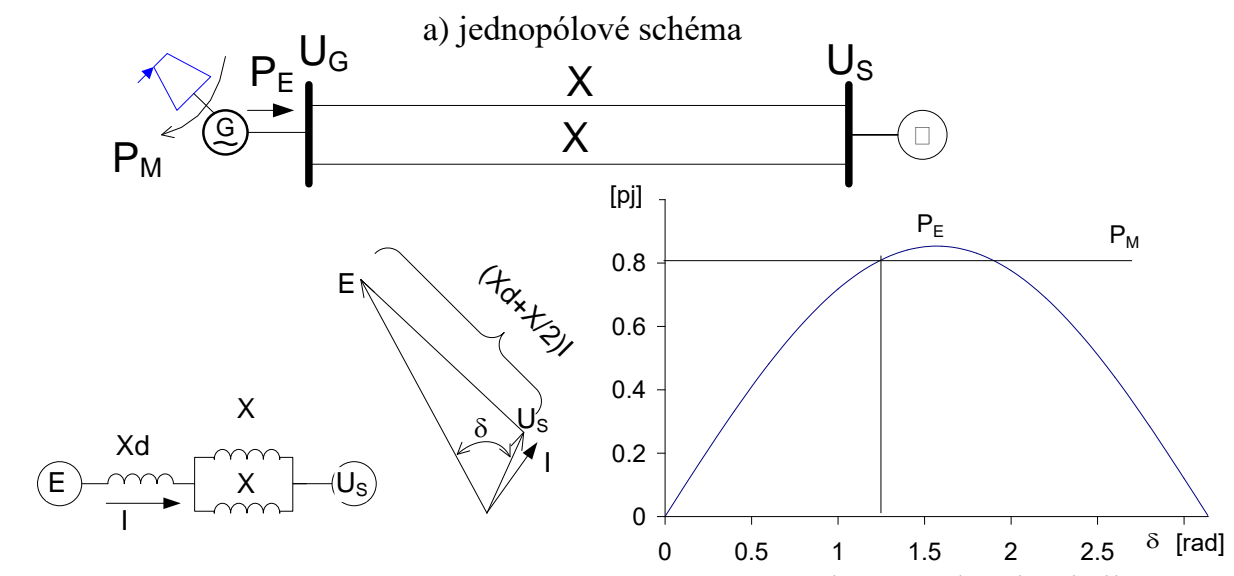

b) náhradní schéma

c) vektorový diagram

d) výkonová charakteristika

Obr. 3.1-1 Model soustavy jeden generátor - tvrdá sít

Jednopólové schéma a) ukazuje základní uspořádání modelu. Synchronní generátor poháněný parní turbínou dodává elektrický výkon $\mathrm{P}_{\mathrm{E}}$ přes dvojité vedení o reaktanci $\mathrm{X}$ do tvrdé sítě charakterizované konstantním napětím US. Ve výchozím stavu je elektrický výkon $\mathrm{P}_{\mathrm{E}}$ roven mechanickému výkonu turbíny $\mathrm{P}_{\mathrm{M}}$ (při zanedbání mechanických a elektrických ztrát).

Synchronní generátor si můžeme nahradit elektromotorickým napětím E za synchronní reaktancí $\mathrm{X}_{\mathrm{d}}$ a vedení jejich reaktancí $\mathrm{X}$, jak ukazuje náhradní schéma $\mathrm{b}$ ). $\mathrm{Z}$ tohoto náhradního schématu odvodíme vektorový diagram c). Úhel $\delta$, který svírají fázory elektromotorického napětí E a napětí $U_{S}$, se nazývá zátěžný úhel. Pro činný elektrický výkon vyráběný synchronním generátorem a přenášený přes vedení do sítě lze odvodit vztah:

$$
P_{E}=\frac{E U_{S}}{X_{\Sigma}} \sin \delta=P_{E \max } \sin \delta,
$$

kde $X_{\Sigma}$ je sumární reaktance mezi napětími E a $U_{S}$.

Výkonová charakteristika ve tvaru sinusovky je znázorněna na obrázku d). Je kreslena v poměrných hodnotách vztažených na jmenovitý zdánlivý výkon generátoru. Amplituda výkonové charakteristiky je určena součinem amplitud obou napětí $\mathrm{E}$ a $U_{S}$ a je nepř́mo úměrná sumární reaktanci. Je-li vedení mezi tvrdou sítí a generátorem dlouhé, je amplituda charakteristiky malá v porovnání s velikostí mechanického výkonu turbíny $\mathrm{P}_{\mathrm{M}}$, který je v obrázku d) zobrazen přímkou. První průsečík sinusovky s př́mkou odleva určuje stabilní pracovní bod $(\delta=1.24 \mathrm{rad}$ v Obr. 3.1-1).

Z rovnice (3.1-1) lze snadno zjistit podmínku pro tzv. statickou stabilitu, kdy dochází $\mathrm{k}$ pomalým změnám provozních veličin:

$$
\frac{d P_{E}}{d \delta}>0 \rightarrow \cos \delta>0 \rightarrow \delta<\frac{\pi}{2}
$$

Ke ztrátě statické stability může dojít pro konstantní hodnotu $X_{\Sigma}$ zvýšením zatížení stroje $\mathrm{P}_{\mathrm{M}}$ nebo snížením vnitřního elektromotorického napětí $\mathrm{E}$. V obou prŕpadech roste hodnota zátěžného úhlu $\delta$. Ukážeme si tyto mechanismy ztráty statické úhlové stability na jednoduchých príkladech využívajících jednostrojový model soustavy. 


\section{Př́íklad 3-1}

Pro soustavu z Obr. 3.1-2 zjistěte maximální přenášený výkon $\mathrm{P}_{\max }$ za podmínek:

1. UZEL_US bude udržovat konstantní jmenovité napětí (tvrdá sít'),

2. generátor bude modelován konstantním napětím za synchronní reaktancí $\mathrm{x}_{\mathrm{d}}$,

3. druhé paralelní vedení V1B bude vypnuto a

4. ve výchozím stavu dodává generátor do uzlu UZEL_US jen činný výkon $\mathrm{P}=50 \mathrm{MW}$.

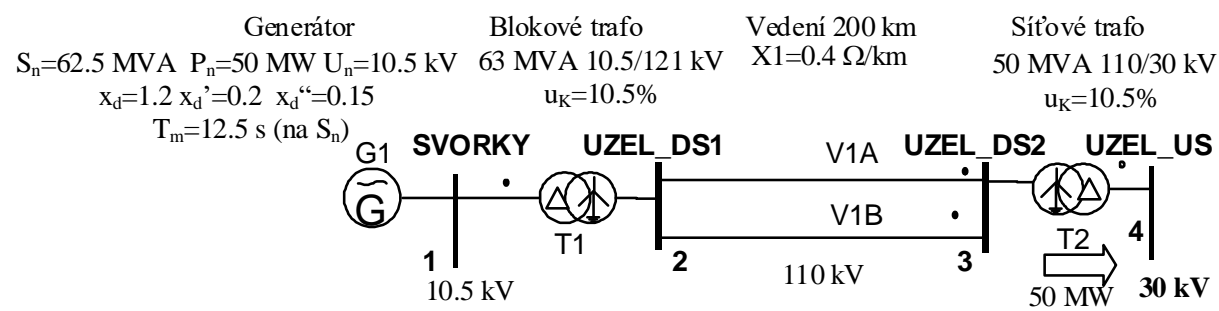

Obr. 3.1-2 Jednopólové schéma jednostrojového modelu soustavy

Př́klad je převzatý ze skripta VUT v Brně [24] (str. 152).

\section{Řěsení}

Podobně jako ve skriptu spočítáme maximální přenášený výkon $\mathrm{P}_{\max }$ ze vztahu (3.1-1). Nejprve spočítáme výslednou reaktanci soustavy $X_{\Sigma}$. Použijeme výpočet v poměrných hodnotách (podíl pojmenovaných a vztažných hodnot) podle náhradního schématu na Obr. 3.1-3.

$$
\begin{aligned}
& \mathrm{S}_{\mathrm{V}}=50 \mathrm{MVA} \\
& \mathrm{U}_{\mathrm{V}}=110 \mathrm{kV} \quad \mathrm{Z}_{\mathrm{V}}=\mathrm{U}_{\mathrm{V}}{ }^{2} / \mathrm{S}_{\mathrm{V}}=110^{2} / 50=242 \Omega
\end{aligned}
$$

Obr. 3.1-3 Náhradní schéma a vektorový diagram pro výchozí stav soustavy

Transformátory jsou modelovány sériovou kombinací ideálního transformátoru (s poměrným převodem $p_{\mathrm{T}}$ ) a reaktance dané poměrným napětím nakrátko $u_{\mathrm{K}}$. $\mathrm{V}$ případě tzv. návazných hladin napětí (kdy jmenovité hodnoty napětí transformátoru jsou totožné se vztažnými napětími sítě) je poměrný převod $p_{\mathrm{T}}$ roven 1 a ve schématu není uveden (to je př́ípad transformátoru T2). Vedení je modelováno reaktancí $X_{\mathrm{V}}$. Generátor je nahrazen elektromotorickým napětím $E_{I}$ za synchronní reaktancí $\mathrm{x}_{\mathrm{d}}$ (náhradní reaktance generátoru $X_{\mathrm{G}}$ je přepočítána přes kvadrát převodu $p_{\text {T }}$ na stranu sítě blokového trafa),

Pro maximální přenášený výkon platí $\mathrm{P}_{\max }=\frac{E U_{S}}{X_{\Sigma}} \mathrm{S}_{\mathrm{V}}=\frac{1.968 \cdot 1}{1.696} 50=58 \mathrm{MW}$.

Nyní můžeme statickou úhlovou stabilitu ověřit i na dynamickém modelu. Výchozí chod sítě SMIB4000 je připraven v projektu UHL_STAB, takže se otevře projekt (1.) a př́ípad ( $\underline{1.1})$ $\mathrm{s}$ tímto chodem. V projektu je již nadefinován $\mathrm{v}$ databázi dynamických modelů bloku tzv. klasický model generátoru ${ }^{1}$ (CLAS) s typovými parametry podle následující tabulky:

\begin{tabular}{|c|c|c|c|c|c|c|c|c|c|c|c|c|c|c|c|}
\hline Generátory & \begin{tabular}{|l|}
$\mathrm{U}_{\mathrm{n}}$ \\
$(\mathrm{kV})$ \\
\end{tabular} & \begin{tabular}{|l|}
$\begin{array}{l}\operatorname{Cos}_{\mathrm{n}} \\
(-)\end{array}$ \\
\end{tabular} & \begin{tabular}{|l}
$\begin{array}{l}\text { Sng } \\
\text { (MVA) }\end{array}$ \\
\end{tabular} & \begin{tabular}{|l}
$\begin{array}{l}X_{d} \\
(-)\end{array}$ \\
\end{tabular} & \begin{tabular}{|l}
$X_{q}$ \\
$(-)$
\end{tabular} & $\begin{array}{c}X_{d}^{\prime} \\
(-)\end{array}$ & \begin{tabular}{|l}
$\mathrm{Xd}^{\prime \prime}$ \\
$(-)$ \\
\end{tabular} & $\begin{array}{l}\begin{array}{l}X_{t} \\
(-)\end{array} \\
\end{array}$ & \begin{tabular}{|l|}
$T_{\mathrm{d} 0}$ \\
$(\mathrm{~S})$ \\
\end{tabular} & \begin{tabular}{|l} 
Tdo" \\
$(\mathrm{s})$ \\
\end{tabular} & \begin{tabular}{|l} 
Tqu" \\
$(\mathrm{s})$ \\
\end{tabular} & $\begin{array}{l}T_{\mathrm{m}} \\
(\mathrm{s}) \\
\end{array}$ & $\begin{array}{c}\mathrm{X}_{q^{\prime}} \\
(-)\end{array}$ & \begin{tabular}{|l}
$T_{q 0}$ \\
$(s)$ \\
\end{tabular} & $\begin{array}{l}\text { Komentár̆ } \\
\text { (text) }\end{array}$ \\
\hline P50CL & 10.5 & 0.8 & 62.5 & 1.2 & 1.2 & 1.2 & 1.2 & 0 & 7.9 & 0.04 & 0.029 & 8.29 & 0.6 & 2.7 & 50MW ze skr. Hodinka CLAS \\
\hline
\end{tabular}

Tab. 3.1-1 Typové parametry generátoru pro konstantní napětí za synchronní reaktancí $X_{d}$

Doba výpočtu se prodlouží na $120 \mathrm{~s}$ (‥). Ve scénáři (3.) se zadá v čase $\mathrm{t}=1 \mathrm{~s}$ pro turbínu změna zadaného činného výkonu bloku G1 zásahem TURB s parametrem 0.135 (zadává se

\footnotetext{
${ }^{1}$ Generátor je v našem případě modelovaný konstantním indukovaným napětí $\mathrm{E}_{\mathrm{I}}$ za zadanou synchronní reaktancí $\mathrm{x}_{\mathrm{d}}$. Pro vyloučení tlumícího momentu generátoru z výpočtu jsou všechny reaktance generátoru v Tab. 3.1-1 stejné.
} 
v poměrných hodnotách vztažených na jmenovitý výkon turbíny, který byl zvolen s ohledem na přetěžování bloku 59.4 MW).

Do grafiky (4.) se zadají pro blok G1 proměnné generátoru a turbíny PG a NT (činný výkon generátoru odpovídající hodnotě $\mathrm{P}_{\mathrm{E}}$ a výkon turbíny odpovídající hodnotě $\mathrm{P}_{\mathrm{M}} \mathrm{z}$ Obr. 3.1-1) a zátěžný úhel generátoru DELT (mezi osou q rotoru a synchronně se otáčející osou vztažného systému, která odpovídá fázoru $\underline{U}_{s}-\mathrm{v}$ předchozím textu značený $\delta$ ).

Po spuštění programu MODES (1.2) jsou v grafech vidět výsledky simulačního výpočtu, jak ukazuje Obr. 3.1-4- stabilní průběh přenášeného výkonu ${ }^{1}$.
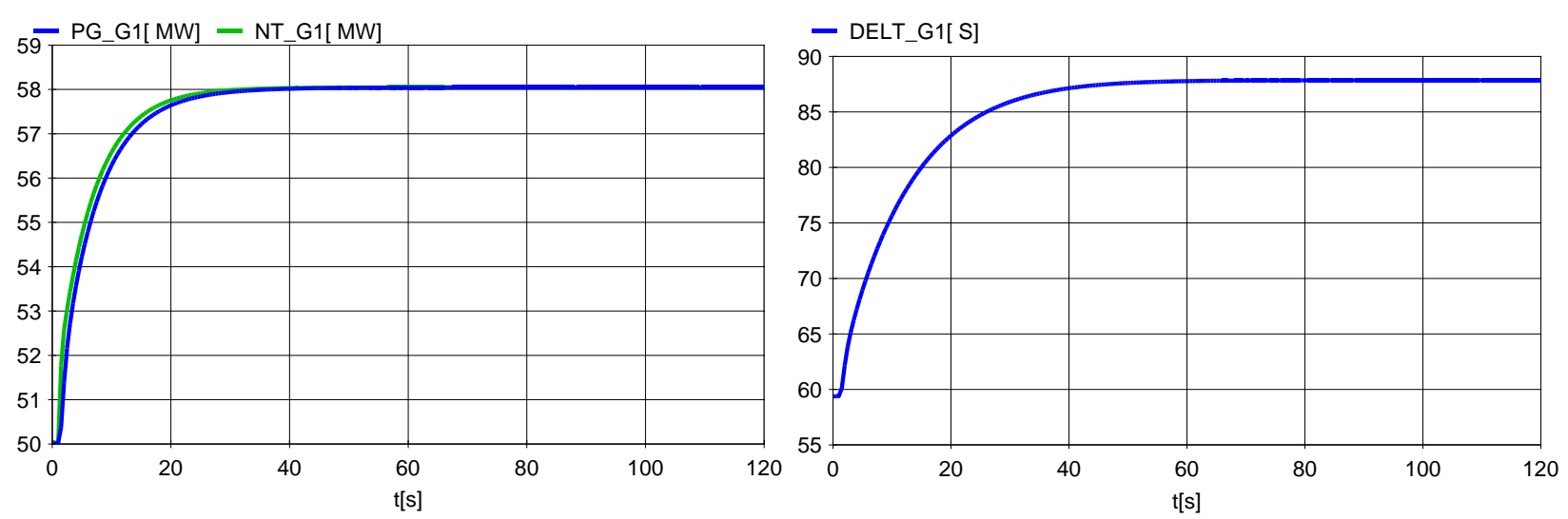

Obr. 3.1-4 Průběhy výkonů generátoru a turbíny a zátěžného úhlu pro stabilní zvýšení výkonu o 8 MW

Pokud ovšem požadavek na zvýšení výkonu turbíny ve scénáři nepatrně zvýšíme, průběh již nebude stabilní. Dojde k asynchronnímu chodu a prokluzu pólů, který se projeví rázy činného výkonu a nárůstem zátěžného úhlu přes stabilní mez $90^{\circ}$. V praxi se tento provoz generátoru řeší odpojením od sítě ochranou na prokluz pólů.
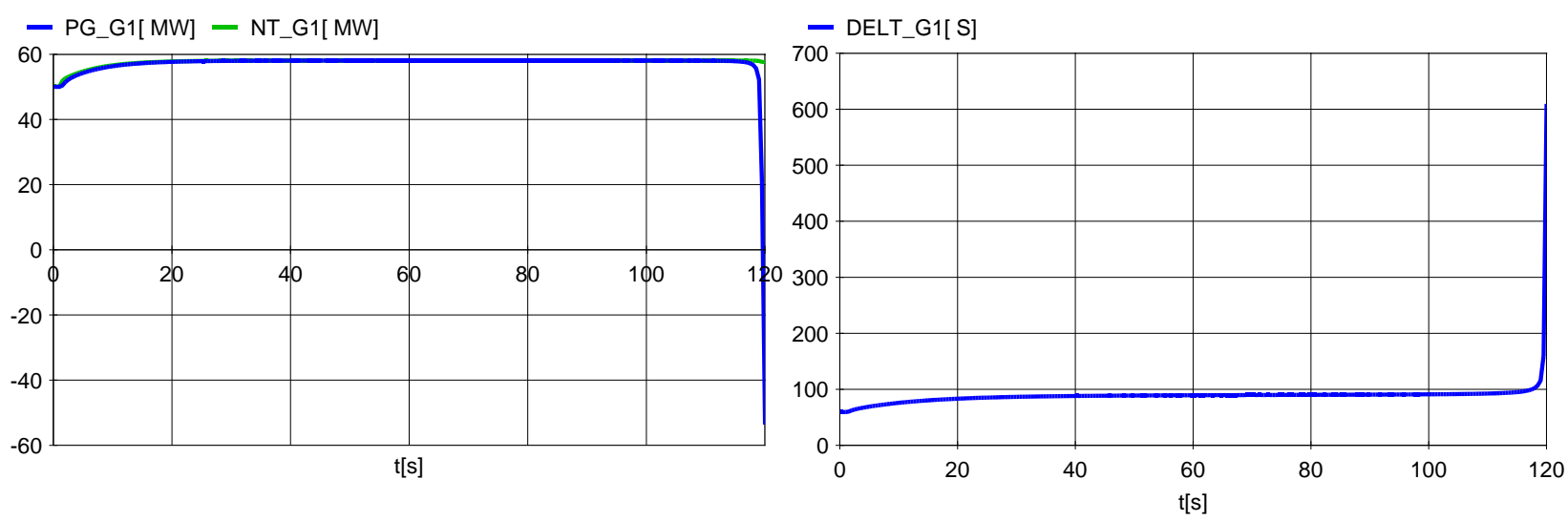

Obr. 3.1-5 Průběhy výkonů a zátěžného úhlu pro ztrátu statické stability zvýšením výkonu o 8.066 MW

Tímto je řešení př́kladu ukončeno a data simulačního výpočtu je vhodné uložit jako př́pad (9.). Rovněž je vhodné uložit si výchozí projekt UHL_STAB pod novým jménem (z menu Projekt/Uložit Jako). Nově uložený projekt převezme případy výchozího projektu i nově uložené př́pady s definovanou identitou řešící př́iklady ze skripta př́ipadně i jiné podle potřeb uživatele.

Při ukončení práce na otevřeném projektu (a před otevřením jiného projektu) a pro zachování dat a výsledků je nutno projekt uložit z menu Projekt/Uložit. Pravidla o ukládání př́ípadů (při dořešení př́íkladu) a projektů (při přerušení práce) mají obecnou platnost a nebudou již dále připomínána.

\footnotetext{
${ }^{1}$ Grafy lze po skončení simulace vytvořit pomocí tlačítek 国 na liště a importovat je jako vektorovou grafiku do dokumentů. U grafů lze měnit rozsahy os a sledovat tak detaily časových průběhů.
} 


\section{Př́klad 3-2}

Pro soustavu z Obr. 3.1-2 s vypnutým paralelní vedením V1B zjistěte při jakém podbuzení (velikosti napětí UB) z výchozího stavu dojde ke ztrátě statické úhlové stability.

\section{Řešení}

Nejprve provedeme statický výpočet pomocí vztahu (3.1-1). Pro minimální velikost napětí $E_{\min }$ pro přenášený výkon $\mathrm{P}=50 \mathrm{MW}$ platí při použití poměrných hodnot $\mathrm{z}$ Obr. 3.1-3 $E_{\text {min }}=\frac{\mathrm{P} X_{\Sigma}}{\mathrm{S}_{\mathrm{V}} U_{S}}=\frac{50 \cdot 1.696}{50 \cdot 1}=1.696$ p.j.

Nyní můžeme ztrátu statické úhlové stability ověřit i na dynamickém modelu. Použijeme stejný chod sítě jako u předchozího př́kladu, ale změníme v editoru (9.) model bloku G1. Pro generátor použijeme tzv. Parkův model ${ }^{1}$ (označený PARK) a zároveň vyměníme parametry za sadu P50PAR:

Tab. 3.1-2 Typové parametry generátoru pro model PARK

\begin{tabular}{|c|c|c|c|c|c|c|c|c|c|c|c|c|c|c|c|}
\hline Gen & \begin{tabular}{|l}
$\mathrm{U}_{\mathrm{n}}$ \\
$(\mathrm{kV})$
\end{tabular} & $\begin{array}{l}\operatorname{Cos}_{n} \\
(-)\end{array}$ & $\begin{array}{l}S_{\text {Sng }} \\
\text { (MVA) }\end{array}$ & \begin{tabular}{|}
$X_{d}$ \\
$(-)$ \\
\end{tabular} & $\begin{array}{l}X_{q} \\
(-)\end{array}$ & \begin{tabular}{|c|}
$\mathrm{X}_{\mathrm{d}^{\prime}}$ \\
$(-)$
\end{tabular} & $\begin{array}{l}X_{d}^{\prime \prime} \\
(-)\end{array}$ & \begin{tabular}{|}
$X_{t}$ \\
$(-)$
\end{tabular} & \begin{tabular}{|l|}
$T_{\mathrm{d} 0}$ \\
$(\mathrm{~s})$
\end{tabular} & $\begin{array}{l}T_{\mathrm{d} 00} \\
(\mathrm{~s}) \\
\end{array}$ & $\begin{array}{l}T_{\mathrm{T}} 0^{\prime} \\
(\mathrm{S})\end{array}$ & \begin{tabular}{|l}
$\mathrm{T}_{\mathrm{m}}$ \\
$(\mathrm{s})$ \\
\end{tabular} & $\begin{array}{c}\mathrm{X}_{\mathrm{q}^{\prime}} \\
(-)\end{array}$ & \begin{tabular}{|c|}
$T_{q 0}{ }^{\prime}$ \\
$(s)$ \\
\end{tabular} & Eár̆ \\
\hline 501 & 10.5 & 0.8 & 62.5 & 1.2 & 1.2 & 0.2 & 20.15 & 0 & 7.9 & 0.04 & 0.029 & 12.5 & 0.6 & 2.7 & OMW \\
\hline
\end{tabular}

Parkův model uvažuje přechodné děje v obvodech synchronního stroje. Zároveň uvážíme i vliv buzení ( $\mathrm{tj}$. změnu budicího napětí $U_{B}$ - vstupní proměnné v Parkových rovnicích) tím, že definujeme standardní model buzení podle Obr. 3.1-6.

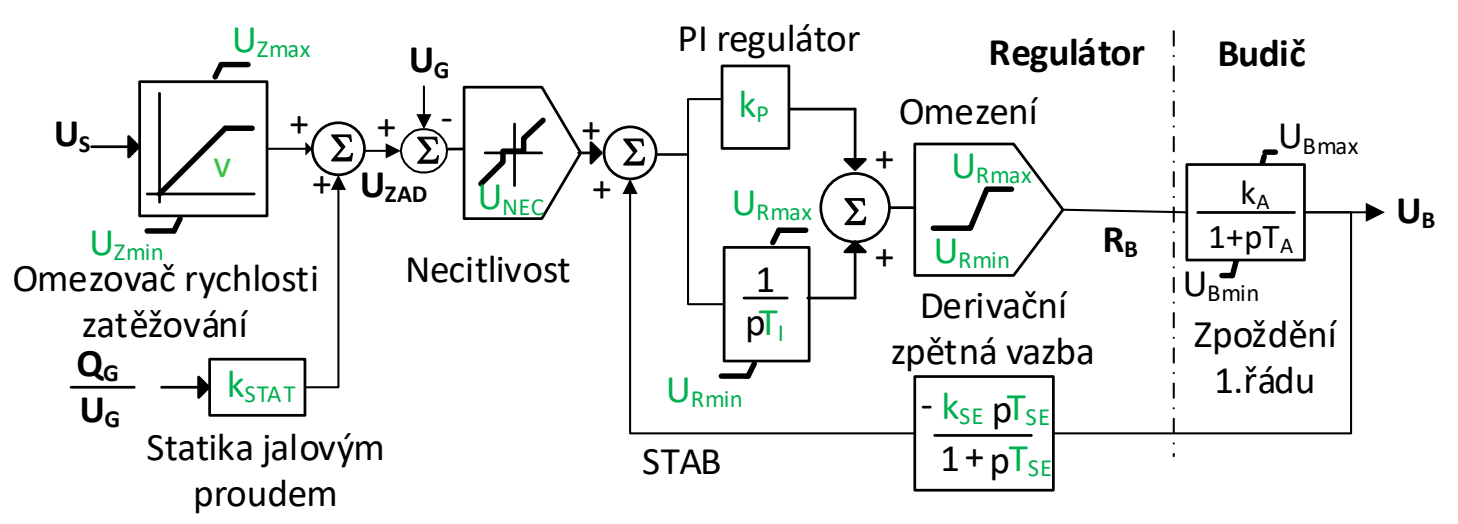

Obr. 3.1-6 Blokové schéma modelu buzení STAN

Pro zadání $T_{I}=0$ se integrační část regulátoru neuvažuje - regulátor je pak jen proporcionální se zesílením $\mathrm{k}_{\mathrm{P}}$ a odpovídá strukturou modelu stejnosměrného budiče modelu DC1 podle doporučení IEEE [26] nebo modelům ExcAVR1 nebo ExcCZ podle novějšího standardu IEC [27]. Podrobněji je modelování budicích systémů popsáno i v článku [28].

V editoru (9.) vyměníme u bloku G1 model pro komponentu Budič za STAN a pro komponentu regulátor buzení vyměníme sadu typových parametrů regulátoru buzení za SODBUD, která umožnuje pomalé odbuzování synchronního stroje (rychlostí v):

Tab. 3.1-3 Typové parametry regulátoru buzení (parametry pro model STAN jsou zvýrazněny tučně)

\begin{tabular}{|c|c|c|c|c|c|c|c|c|c|c|c|c|c|c|}
\hline Regulatory_B & $\begin{array}{l}\text { Uzmin } \\
(-)\end{array}$ & $\begin{array}{l}\text { Uzmax } \\
(-)\end{array}$ & $\begin{array}{l}\text { Unec } \\
(-)\end{array}$ & $\begin{array}{l}\text { Kstat } \\
(-)\end{array}$ & $\begin{array}{l}\mathrm{Kp} \\
(-) \\
\end{array}$ & $\begin{array}{c}\text { Kse } \\
(-)\end{array}$ & \begin{tabular}{|l} 
TI \\
$(s)$
\end{tabular} & \begin{tabular}{|l} 
Ts \\
(s)
\end{tabular} & \begin{tabular}{|l} 
T1 \\
(s)
\end{tabular} & $\begin{array}{l}\text { T3 } \\
\text { (s) }\end{array}$ & $\begin{array}{l}\mathbf{v} \\
\left(\frac{0}{0} / \mathrm{s}\right)\end{array}$ & $\begin{array}{l}\text { Urmax } \\
(-)\end{array}$ & $\begin{array}{l}\text { Urmin } \\
(-)\end{array}$ & $\begin{array}{c}\text { Koment } \\
\text { (text) }\end{array}$ \\
\hline SODBUD & 0 & 1.2 & 0 & 0.05 & 100 & 0.2 & 0 & 1 & 0 & 0 & 0.9 & 9.5 & -9.5 & pomalé odbuzování \\
\hline
\end{tabular}

Parametry budiče můžeme ponechat beze změny jako defaultní sadu defaul.

Tab. 3.1-4 Typové parametry budiče (parametry pro model STAN jsou zvýrazněny tučně)

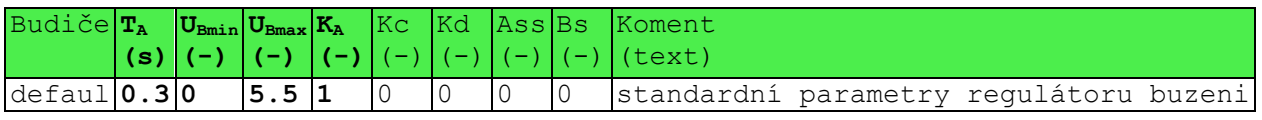

\footnotetext{
1 (viz např. [25]str. 346 nebo elektronická dokumentace k programu MODES v položce Popis modelování/Model generátoru/Rovnice synchronního stroje po kliknutí na záložku Dokumentace)
} 
Dobu výpočtu zkrátíme na 50 s (‥). Do scénáře (3.) zadáme pro budič bloku G1 v čase $\mathrm{t}=1 \mathrm{~s}$ změnu požadovaného napětí $\mathrm{U}_{\mathrm{S}}{ }^{1}$ generátoru $\mathrm{Gl}$ zásahem EXCT s parametrem -0.39 (zadává se v poměrných hodnotách vztažených na jmenovité napětí generátoru). Tím bude budič odbuzovat a generátor snižovat svorkové napětí.

Do grafiky (4.) se zadají pro blok G1 proměnné UB a IB (poměrné budicí napětí a budicí proud, který v modelu generátoru odpovídá elektromotorické síle $\mathrm{E}_{\mathrm{q}}$ za synchronní reaktanci $\mathrm{x}_{\mathrm{d}}$ ).

Obr. 3.1-7 již ukazuje výsledky simulačního výpočtu - stabilní průběh odbuzování.
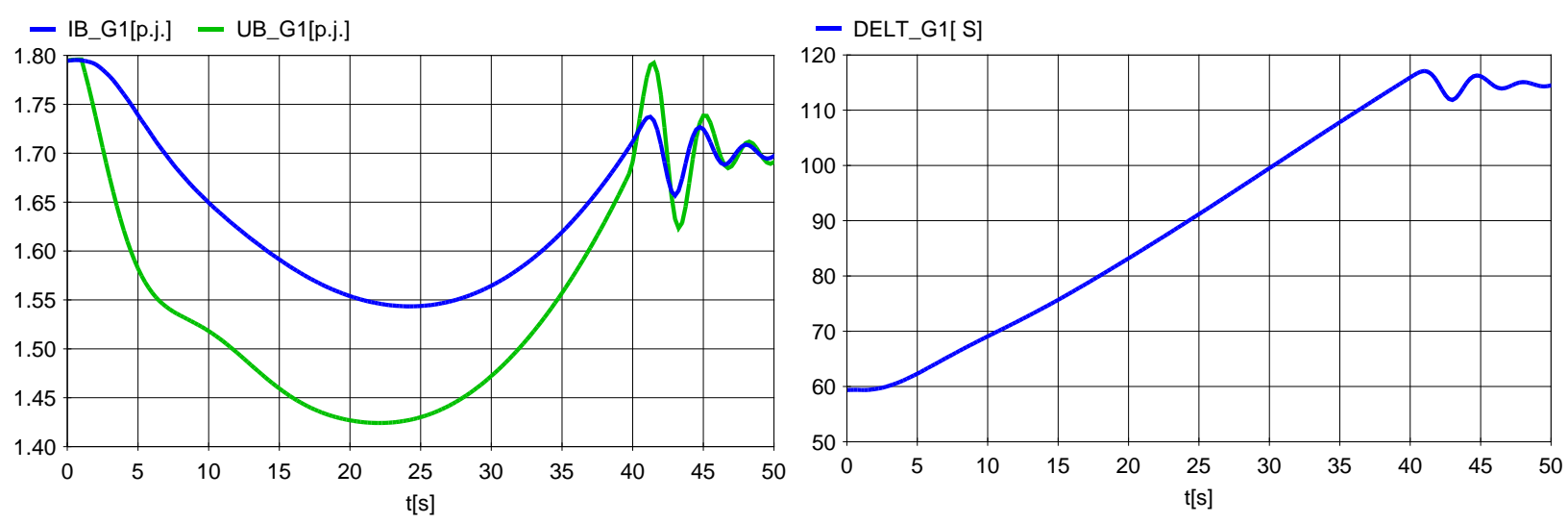

Obr. 3.1-7 Průběhy budicího napětí a proudu a zátěžného úhlu při odbuzování $k$ mezi statické stability

$\mathrm{Na}$ průběhu zátěžného úhlu DELT je vidět překročení meze 90 stupňů těsně před dosažením $\mathrm{t}=25 \mathrm{~s}$. Po skončení regulačního děje pracuje generátor v oblasti tzv. umělé stability, umožněné regulátorem buzení.

Průběh budícího proudu IB (respektive elektromotorického napětí $E_{\mathrm{q}}$ ) ukazuje minimální hodnotu $\mathrm{IB}_{\min }=1.543$, což odpovídá analyticky spočtené hodnotě U $\mathrm{Bmin}_{\mathrm{S}} \mathrm{s}$ uvážením, že hodnota $U_{B}$ je přepočtená přes převod blokového trafa na stranu sítě VVN, čili je 1.1 x větší (viz náhradní schéma na Obr. 3.1-3). Tato hodnota je dosažena pro zátěžný úhel DELT=90 stupňů. Při dalším poklesu svorkového napětí v oblasti umělé stability už budič musí elektromotorické napětí $E_{\mathrm{q}}$ znovu zvyšovat. Čtenář se o tom může přesvědčit i nakreslením vektorových diagramů.

V případě nepatrného zmenšení požadovaného poklesu svorkového napětí o dalších -0.01 p.j. (ve scénáři (3.)) dochází k netlumeným kmitům, jak ukazuje Obr. 3.1-8.
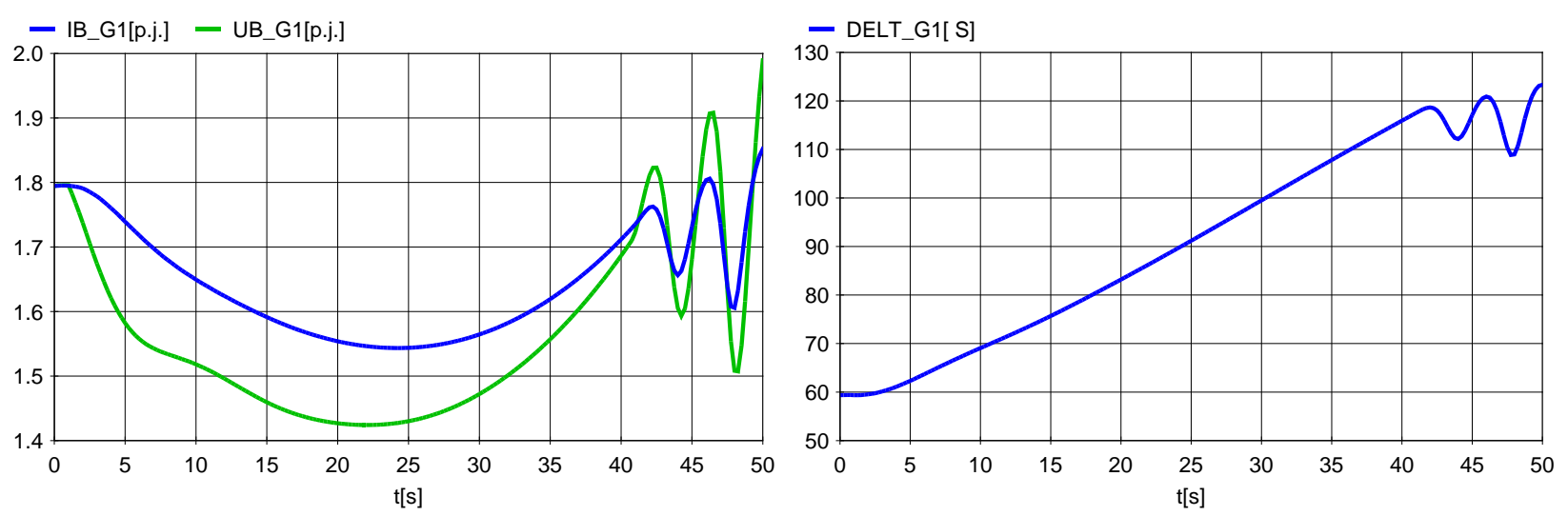

Obr. 3.1-8 Průběhy budicího napětí a proudu a zátěžného úhlu při překročení meze oscilační stability

Při dalším zmenšení poklesu svorkového napětí o -0.01 již dojde ke ztrátě statické stability a k asynchronnímu chodu.

\footnotetext{
${ }^{1}$ Požadované napětí US je výstupem sekundárního regulátoru jalového výkonu nebo je lze měnit ručním zásahem
} 


\section{2 Úhlová přechodná stabilita a pravidlo ploch}

Zatímco statická stabilita se zabývala pomalými změnami, u přechodné stability se bude jednat o rychlé změny při poruchách v síti.

Pro výklad použijme opět jednostrojový model soustavy. Pokud z výchozího stavu dojde k výpadku jednoho z paralelních vedení, nastane přechodný děj, který lze vysvětlit na výkonových charakteristikách kreslených na Obr. 3.2-1.
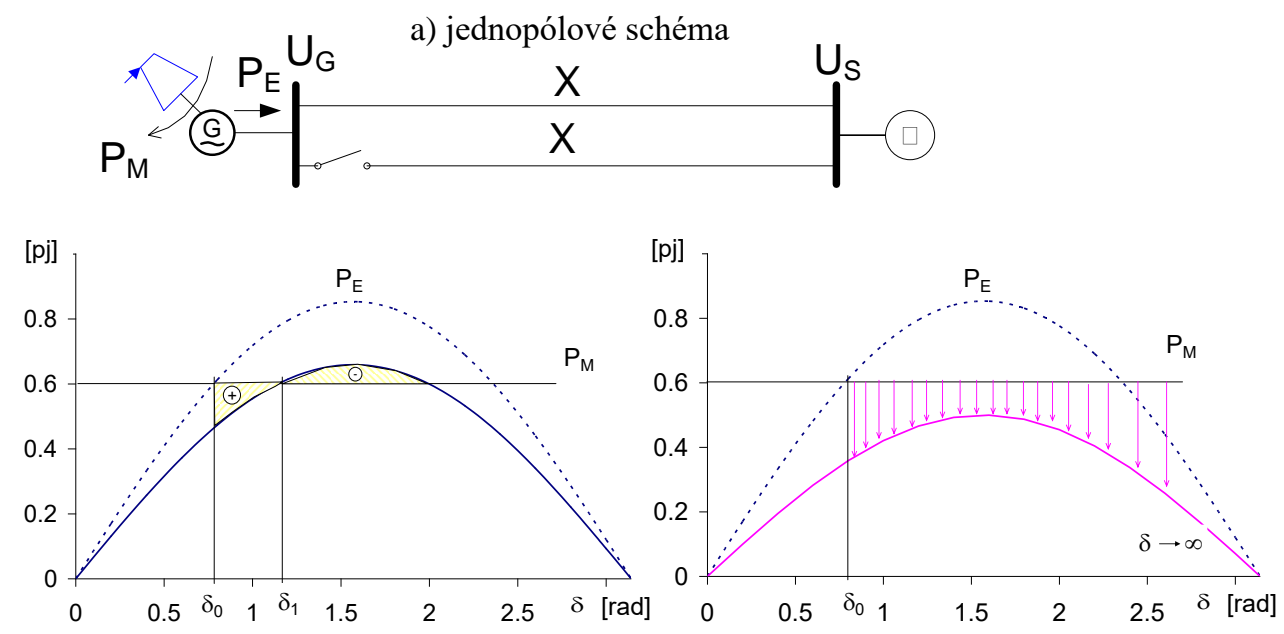

b) stabilní přechod

c) nestabilní přechod

\section{Obr. 3.2-1 Model výpadku vedení}

V př́padě, že poměr reaktancí vedení k reaktanci generátoru bude dostatečně malý, nastane stabilní přechodný děj zobrazený na obrázku b). Původní tečkovaná výkonová charakteristika se skokem změní na novou, kreslenou plnou čarou. Zátěžný úhel $\delta$ se začíná měnit podle diferenciální pohybové rovnice:

$$
\frac{\mathrm{T}_{\mathrm{M}}}{\omega_{0}} \frac{\mathrm{d}^{2} \delta}{\mathrm{dt}^{2}}=M_{M}-M_{E} \approx P_{M}-P_{E}=P_{A},
$$

kde $T_{M}$ je mechanická časová konstanta spočtená z momentu setrvačnosti soustrojí a $\omega_{0}$ je synchronní kruhová rychlost.

$\mathrm{V}$ rovnici jsme použili místo momentů výkony (v poměrných hodnotách a při malých odchylkách otáček od synchronních jsou obě veličiny stejné). Akcelerační výkon $\mathrm{P}_{\mathrm{A}}$ na pravé straně rovnice je určen rozdílem pořadnic př́mky mechanického výkonu a sinusovky elektrického výkonu. Po vypnutí jednoho z vedení je $\mathrm{P}_{\mathrm{E}}$ menší než $\mathrm{P}_{\mathrm{M}}$ a zátěžný úhel $\delta$ se začíná zvětšovat - rotor stroje se urychluje. V bodě $\delta_{1}$ se výkony srovnají, ale rotor se pohybuje setrvačností dál. Žlutě šrafovaná plocha označená znaménkem plus odpovídá kinetické energii, kterou rotor získal pohybem z polohy $\delta_{0}$ do polohy $\delta_{1}$ (akcelerační plocha). Pokud je brzdicí plocha označená znaménkem minus větší nebo rovna akcelerační ploše, rotor se zpomalí a nakonec se ustálí v nové rovnovážné poloze $\delta_{1}$ (tzv. pravidlo ploch). V opačném př́padě je rotor zrychlován, zátěžný úhel $\delta$ roste a stroj ztratí stabilitu.

Ke ztrátě stability dojde i v př́ípadě, že reaktance vedení bude velká (dlouhé vedení) a výkonová charakteristika klesne pod přímku mechanického výkonu. Rotor stroje bude urychlován stálým akceleračním výkonem (který je v obrázku c) zvýrazněn fialovými šipkami) a zátěžný úhel $\delta$ poroste - stroj přejde do asynchronního chodu. Tento chod se projeví rázy činného výkonu, které namáhají hř́idel a přes stator se přenášejí na základy soustrojí a mohou je poškodit. Proto musí být takový stav včas vyhodnocen a generátor ochranami vypnut. 


\section{Př́ḱlad 3-3}

Pro soustavu z Obr. 3.1-2 zjistěte frekvenci kyvů při vypnutí jednoho z vedení. S pomocí simulačního výpočtu na dynamickém modelu sestrojte i trajektorii těchto kyvů v rovině $\mathrm{P}-\delta$.

\section{Řešení}

Nejprve provedeme výpočet frekvence kyvů analyticky. Vyjdeme z rovnice kyvu (3.2-1), přičemž v souladu s doporučením skripta [24] str. 136, bude generátor tentokrát (pro výpočty přechodné stability) nahrazen elektromotorickou silou za přechodnou reaktancí $\mathrm{x}_{\mathrm{d}}$ '. Proto nyní zátěžný úhel budeme značit $\vartheta$. Do rovnice kyvu dosadíme za elektrický výkon $\mathrm{P}_{\mathrm{E}} \mathrm{z}$ rovnice pomocí vztahu (3.1-1), který pro dosažení řešení linearizujeme ${ }^{1} \mathrm{v}$ okolí nového pracovního bodu $\vartheta_{1}\left(\vartheta_{=} \vartheta_{1}+\Delta \vartheta\right)$. Linearizovaná rovnice kyvu přejde do tvaru:

$$
\frac{\mathrm{T}_{\mathrm{M}}}{\omega_{0}} \frac{\mathrm{d}^{2} \Delta \vartheta}{\mathrm{dt}^{2}}=-P_{S} \Delta \vartheta, \quad P_{S}=\frac{E U_{S}}{X_{\Sigma 1}} \cos \left(\vartheta_{1}\right), \quad P_{M}=\frac{E U_{S}}{X_{\Sigma 1}} \sin \left(\vartheta_{1}\right),
$$

kde $P_{S}$ je tzv. synchronizační výkon (rovný derivaci $P_{E}$ podle $\vartheta$ v pracovním bodě $\vartheta_{1}$ ).

Linearizovaná rovnice má snadné analytické řešení. Charakteristická rovnice má tvar:

$$
\frac{\mathrm{T}_{\mathrm{M}}}{\omega_{0}} p^{2}=-P_{S}
$$

a dva kořeny, které jsou pro $P_{S}>0$ komplexně sdružené:

$$
p_{1,2}= \pm \mathrm{j} \sqrt{\frac{P_{S} \omega_{0}}{\mathrm{~T}_{\mathrm{M}}}}= \pm \mathrm{j} \Omega= \pm \mathrm{j} 2 \pi f \quad \Rightarrow \quad f=\frac{1}{2 \pi} \sqrt{\frac{P_{S} \omega_{0}}{\mathrm{~T}_{\mathrm{M}}}} .
$$

Po vypnutí jednoho vedení tedy dochází k netlumeným kyvům o frekvenci f. Pro výpočet frekvence kyvů nejprve zjistíme hodnoty synchronizačního výkonu. Použijeme k tomu fázorové diagramy pro výchozí stav a pro rovnovážný stav po vypnutí vedení z následujícího obrázku.

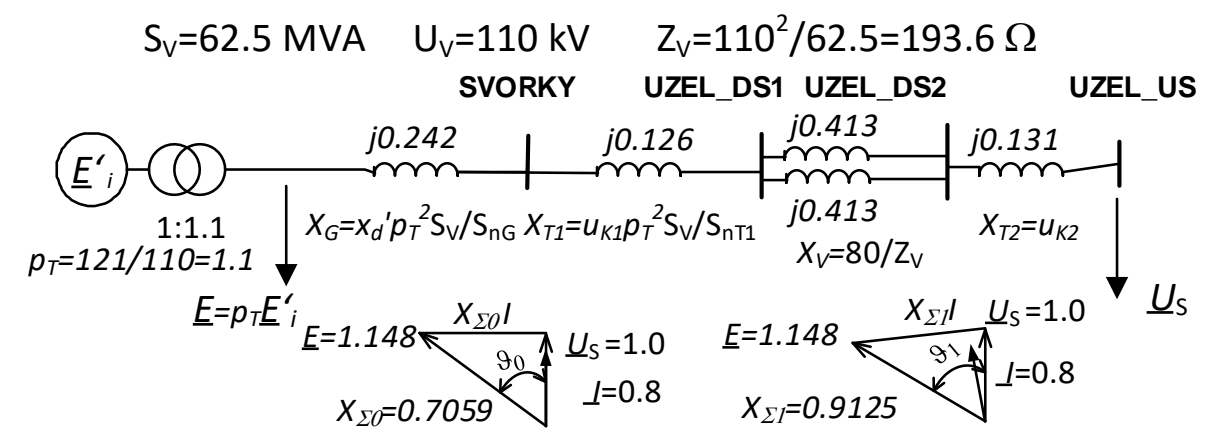

Obr. 3.2-2 Náhradní schéma a fázorový diagram pro výchozí stav (vlevo) a rovnovážný stav po vypnutí

Amplitudu fázoru $\underline{E}$ zjistíme z výchozího fázorového digramu (pro kývání po vypnutí vedení se tato hodnota nezmění). Hodnotu $\vartheta_{1}$ zjistíme z rovnosti pro $P_{M} \mathrm{v}$ (3.2-2): $\vartheta_{1}=\arcsin \left(P_{M} X_{\Sigma 1} / E / U_{S}\right)=\arcsin (0.8 \cdot 0.9125 / 1.148)=39.5^{\circ}$. Hodnota synchronizačního výkonu je pak rovna $P_{S}=1.148 / 0.9125 \cdot \cos \left(39.5^{\circ}\right)=0.971$.

Po dosazení do rovnice (3.2-4) obdržíme hodnotu frekvence kyvů f $=0.786 \mathrm{~Hz}$.

Nyní můžeme frekvenci kyvů ověřit i na dynamickém modelu. V Editoru chodů (‥) zapneme vedení V1B a dodávaný výkon generátoru G1 do uzlu SVORKY upravíme tak, aby dodávka do uzlu UZEL_US byla nulová (Pdod=0, Qdod=0). Vznikne nový chod sítě SMIB4111.

\footnotetext{
${ }^{1}$ Jinak by rovnice kyvu odpovídala rovnici matematického kyvadla, která nemá elementární řešení. Linearizace se týká vztahu $\left.\sin \vartheta \approx \sin \vartheta_{1}+\cos \vartheta_{1} \Delta \vartheta\right)$, kde úhel $\vartheta_{1}$ zjistíme řešením rovnice rovnosti $P_{\mathrm{M}}=P_{\mathrm{E}}$ ve výchozím ustáleném stavu.
} 
V Editoru modelů bloku (7.) vyměníme u generátoru G1 model za klasický CLAS a vybereme pro něj sadu typových parametrů P50CLT:

Tab. 3.2-1 Typové parametry generátoru pro konstantní napětí za přechodnou reaktancí $X_{d}{ }_{d}$

\begin{tabular}{|c|c|c|c|c|c|c|c|c|c|c|c|c|c|c|c|}
\hline Eory & \begin{tabular}{|l|}
$\mathrm{Un}_{\mathrm{n}}$ \\
$(\mathrm{kV})$ \\
10
\end{tabular} & \begin{tabular}{|l|}
$\operatorname{Cos}_{n}$ \\
$(-)$ \\
\end{tabular} & $\begin{array}{l}\text { Sng } \\
\text { (MVA) }\end{array}$ & $\begin{array}{l}X_{d} \\
(-) \\
n\end{array}$ & $\begin{array}{c}X_{q} \\
(-) \\
\end{array}$ & \begin{tabular}{|c|}
$\mathrm{Xd}^{\prime}$ \\
$(-)$
\end{tabular} & $\begin{array}{c}\mathrm{Xd}_{\mathrm{d}} \\
(-) \\
\end{array}$ & $\begin{array}{l}X_{t} \\
(-)\end{array}$ & $\begin{array}{l}T_{\mathrm{d} 0^{\prime}} \\
(\mathrm{s}) \\
7\end{array}$ & \begin{tabular}{|c|} 
Tao" \\
$(\mathrm{s})$ \\
\end{tabular} & $\begin{array}{l}\text { Tq" } \\
(\mathrm{s})\end{array}$ & \begin{tabular}{|l|}
$\mathrm{T}_{\mathrm{m}}$ \\
$(\mathrm{s})$ \\
12
\end{tabular} & $\begin{array}{c}\mathrm{Xq}^{\prime} \\
(-) \\
\end{array}$ & \begin{tabular}{|l|} 
Tq0 \\
(s) \\
\end{tabular} & $\begin{array}{l}\text { Komentář } \\
\text { (text) }\end{array}$ \\
\hline POCLT & 10.5 & 0.8 & 62.5 & 0.2 & 0.2 & 0.2 & 0.2 & 0 & 7.9 & 0.04 & 0.029 & 12.5 & 0.2 & 2.7 & $50 \mathrm{MW}$ ze skr. Hodinka CLAS \\
\hline
\end{tabular}

Generátor tedy bude modelován konstantním napětím za přechodnou reaktancí.

Dobu výpočtu zkrátíme na $25 \mathrm{~s}$ ( $\underline{5}$.). Do scénáře (3.) se zadá v čase $\mathrm{t}=1 \mathrm{~s}$ pro objekt Vedení zásah BRAN (zapojení/odpojení větve) na vedení V1B (parametr VYP). Do grafiky (ㄸ.) se zadají pro blok G1 proměnné DELT (tato proměnná nyní označuje úhel Э) a PG.

Obr. 3.2-3 již ukazuje výsledek simulačního výpočtu - netlumené kyvy činného výkonu:
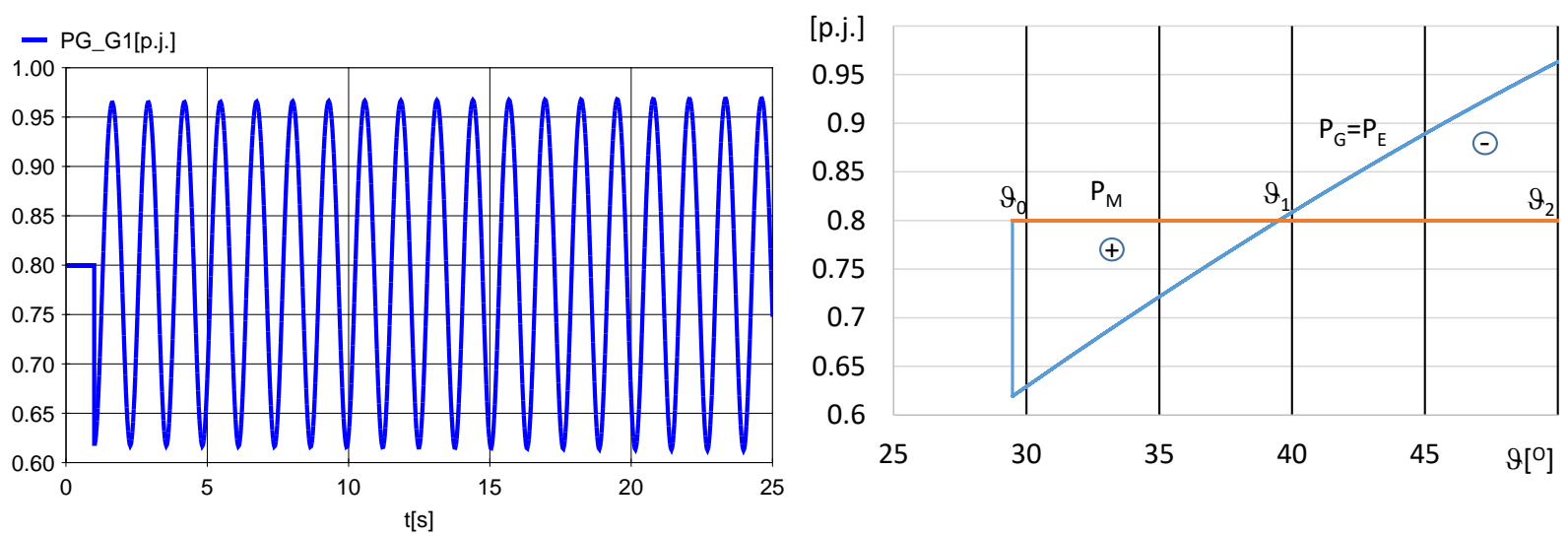

Obr. 3.2-3 Průběh výkonu generátoru a výkonová charakteristika při netlumených kyvech

Kyvy mají harmonický - téměř sinusový průběh s frekvencí odpovídající hodnotě spočtené analyticky. Plochy obou skoro trojúhelníků (ve skutečnosti jsou přepony určeny skoro lineární částí sinusovky) ve výkonové charakteristice vpravo, označené znaménky + a -, jsou si rovny.

Pokud se vrátíme $\mathrm{k}$ Parkovu modelu generátoru z př́kladu 3-2, budou průběhy činného výkonu a trajektorie $\mathrm{P}$ - $\delta$ (zde je opět zátěžný úhel $\delta$ úhlem mezi osou q-rotoru a referenčním fázorem $\underline{U}$ s) podle Obr. 3.2-4.
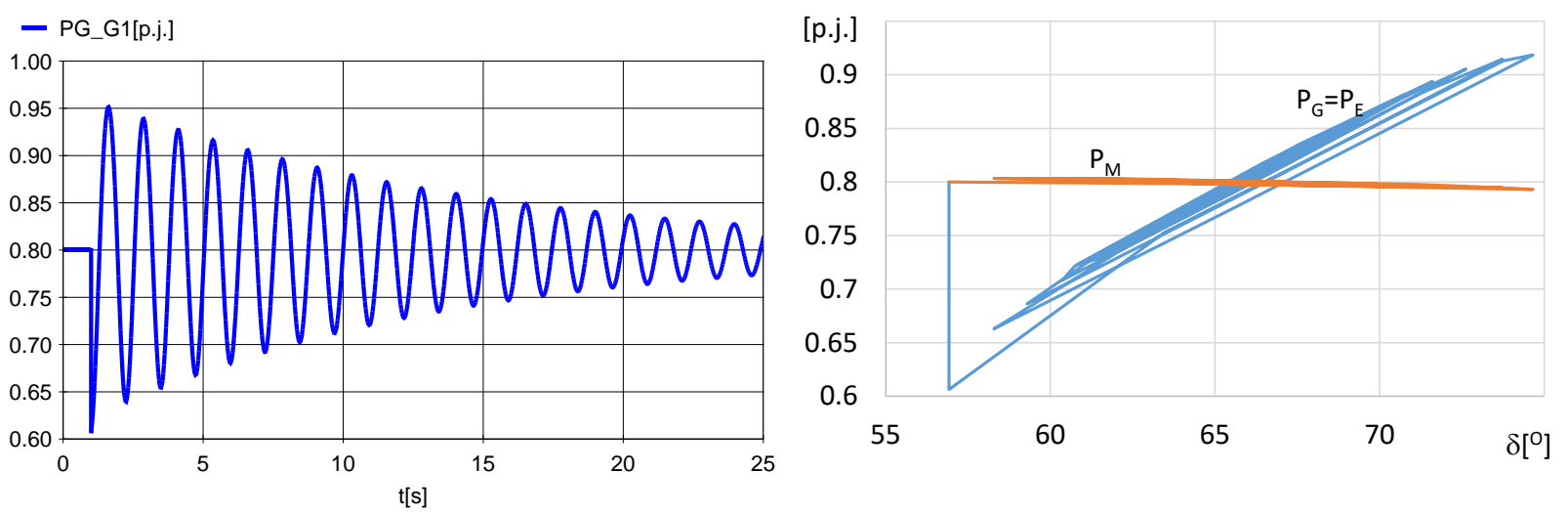

Obr. 3.2-4 Průběh výkonu generátoru a výkonová charakteristika při tlumených kyvech

K tlumení dochází jednak v obvodech rotoru (budicích a tlumicích) a jednak činností regulátoru buzení.

\footnotetext{
${ }^{1}$ Časové průběhy vybraných veličin, které jsou uložené $\mathrm{v}$ textových výstupních souborech lze naimportovat do EXCELu z menu Výsledky při zaškrtnuté volbě Otevř́ít v EXCELu
} 
Podmínky pro udržení stabilního chodu synchronního generátoru se zhorší, dojde-li na jednom vedení ke zkratu. Př́ípad je zobrazen na Obr. 3.2-5.
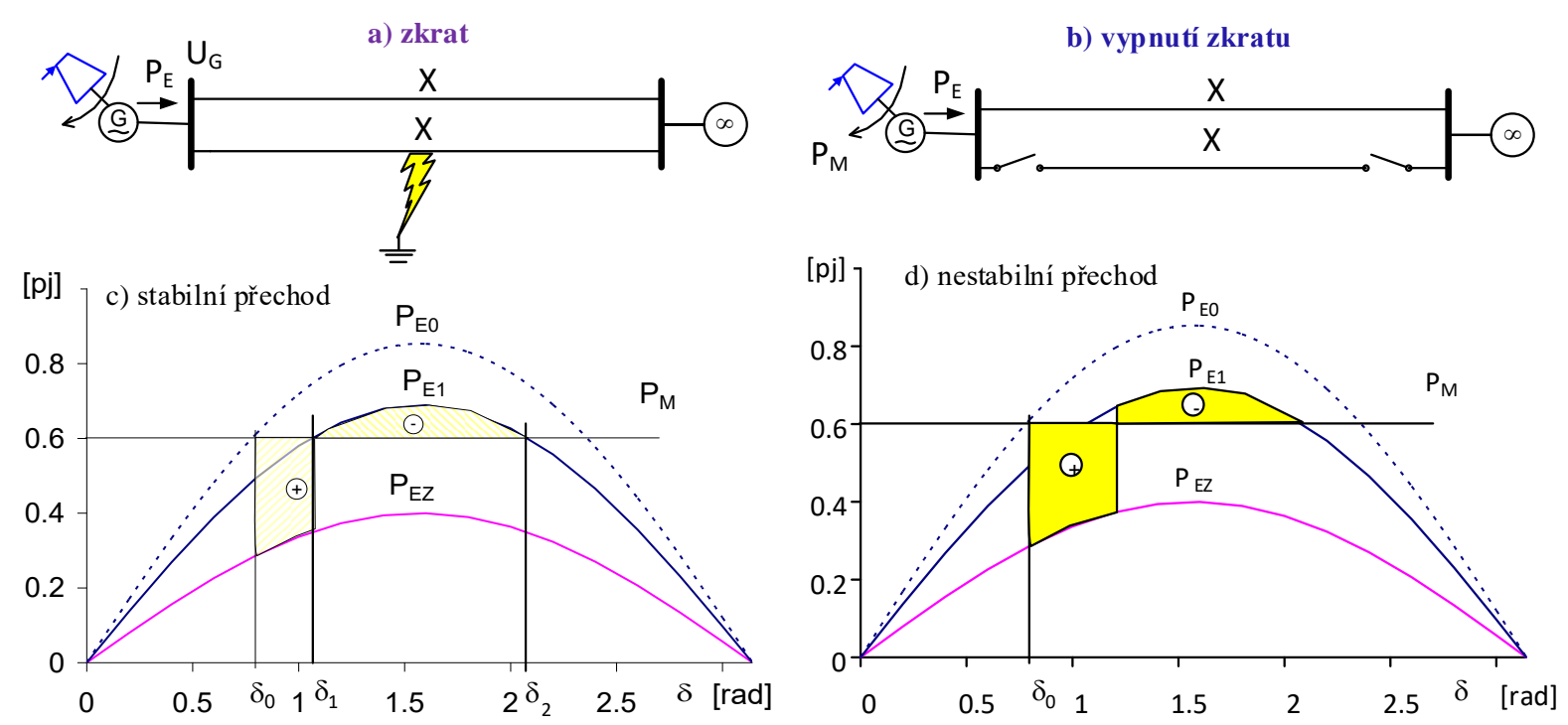

Obr. 3.2-5 Výkonové charakteristiky synchronního generátoru při zkratu

Přechodný děj bude mít nyní dvě fáze: zkrat a stav po vypnutí zkratu včetně postiženého vedení (obrázek b). Každá fáze má svoji výkonovou charakteristiku, jak ukazuje obrázek c). Při zkratu klesá výkonová charakteristika z původní $\mathrm{P}_{\mathrm{E} 0} \mathrm{na} \mathrm{P}_{\mathrm{EZ}}$. Rotor se začíná urychlovat a nabírá kinetickou energii odpovídající žlutě vyšrafované ploše označené znaménkem + . Po vypnutí zkratu se přechází na charakteristiku $\mathrm{P}_{\mathrm{E} 1}$. Opět platí pravidlo ploch. Pro stabilní děj musí být brzdicí plocha větší nebo rovna akcelerační, jak ukazuje obrázek c, kdy po vypnutí zkratu se zátěžný úhel ustálí v nové rovnovážné poloze $\delta_{1}$.

Velikost akcelerační plochy je dána jednak rozdílem výkonu turbíny $\mathrm{P}_{\mathrm{M}}$ a generátoru $\mathrm{P}_{\mathrm{E}}$ a jednak dobou trvání zkratu. Pro zachování stability je nutné, aby akcelerační plocha byla co nejmenší. Toho dosáhneme zejména zkrácením doby trvání zkratu tím, že zkrat bude ochranami včas rozpoznán a vypínači co nejrychleji vypnut. Moderní digitální ochrany a výkonné vypínače instalované v přenosové soustavě dokáží tento čas zkrátit pod 100 ms. Doba trvání zkratu, při kterém se akcelerační plocha rovná brzdicí se nazývá mezní doba trvání zkratu (angl. „Critical Clearing Time“ - CCT). Do této doby musí být zkrat vypnut, jinak dojde ke ztrátě stability. Odpovídající zátěžný úhel se nazývá kritický úhel $\delta_{C}$.

Pokud známe mezní úhly, můžeme z nich aproximovat mezní dobu vypnutí zkratu neboli CCT. Pohybovou rovnice (3.2-1) můžeme přepsat do tvaru:

$$
\frac{\mathrm{d} s}{\mathrm{dt}}=\frac{P_{A}}{\mathrm{~T}_{\mathrm{M}}}, \quad \frac{\mathrm{d} \delta}{\mathrm{dt}}=\omega_{0} s,
$$

kde jsme zavedli bezrozměrný skluz $s=\omega / \omega_{0}-1$ jako poměrnou odchylku kruhové rychlosti od jmenovité. Po integraci diferenciální rovnice pro zátěžný úhel, náhradou skluzu lineárním nárůstem během doby zkratu (způsobeným střední hodnotou akceleračního výkonu $P_{A s}$ ) a substitucí času $\tau=\mathrm{t}-\mathrm{t}_{0}$, obdržíme integrální rovnice a jejich řešením i vztah pro výpočet $\mathrm{CCT}$ :

$$
\begin{gathered}
\int_{\delta_{0}}^{\delta_{C}} \mathrm{~d} \delta=\int_{\mathrm{t}_{0}}^{\mathrm{t}_{C}} \omega_{0} s \mathrm{dt}=\omega_{0} \frac{P_{A s}}{T_{M}} \int_{\mathrm{t}_{0}}^{\mathrm{t}_{C}}\left(\mathrm{t}-\mathrm{t}_{0}\right) \mathrm{dt}=\omega_{0} \frac{P_{A s}}{T_{M}} \int_{0}^{C C T} \tau \mathrm{d} \tau \\
C C T \approx \sqrt{\frac{2 T_{M}\left(\delta_{\mathrm{C}}-\delta_{0}\right)}{\omega_{0} P_{A s}}}[\mathrm{~s}, \mathrm{~s}, \mathrm{rad}, \mathrm{rad} / \mathrm{s}, \mathrm{p} . \mathrm{j} .] .
\end{gathered}
$$




\section{Př́klad 3-4}

V soustavě z Obr. 3.1-2 vznikl uprostřed vedení V1B trojpólový zkrat. Zjistěte výkonové charakteristiky, průběhy zátěžného úhlu a křivky kyvu (trajektorie kývání P-Э) pro případy:

a) zkrat nebude vypnut (selhání vypínače),

b) zkrat se vypne i s vedením za $0.2 \mathrm{~s}$,

c) zkrat se vypne i s vedením za $0.5 \mathrm{~s}$.

\section{̌̌Rě̌ení}

Př́klad odpovídá př́kladu 3.4.3 ze skripta VUT v Brně [24] (str. 174).

Nejprve provedeme výpočet výkonových charakteristik analyticky. Využijeme hodnot reaktancí spočtených v náhradním schématu na Obr. 3.2-2 pro stav před poruchou a po jejím vypnutí (generátor nahradíme konstantní elektromotorickou silou $\mathrm{E}^{‘}$ za přechodnou reaktancí).

Zbývá dopočítat náhradní reaktanci pro zkrat na vedení. V náhradním schématu se zkrat projeví připojením nulové reaktance mezi střed vedení a zem. Po provedení dvojí transfigurace hvězda - trojúhelník obdržíme hodnotu náhradní reaktance $X_{\Sigma Z}=2.844$. Nyní již snadno podle vztahu (3.1-1) dopočítáme amplitudy výkonových charakteristik: $P_{\operatorname{Emax} 0}=1.148 \cdot 1 / 0.7059$ $=1.626, P_{\operatorname{Emax} 1}=1.148 \cdot 1 / 0.9125=1.258, P_{\text {EmaxZ }}=1.148 \cdot 1 / 2.844=0.404$. Tyto amplitudy vycházejí o něco málo vyšší oproti skriptu, zřejmě vlivem odlišných napětových poměrů.

Pro simulační výpočty lze vyjít z předchozího příkladu 3-3 a použít stejný chod sítě SMIB4111 a klasický model generátoru CLAS se sadou typových parametrů P50CLT.

Dobu výpočtu zkrátíme na $1 \mathrm{~s}(\underline{5}$.). Do scénáře (3.) se zadá v čase $\mathrm{t}=0.1 \mathrm{~s}$ pro objekt Vedení trojfázový zkrat zásahem FOUL na vedení V1B s parametry 50 (zkrat v 50\% délky vedení) a 0 (kovový zkrat). Pro případy b) a c) doplníme $\mathrm{v}$ časech $\mathrm{t}=0.3$ a $\mathrm{t}=0.6 \mathrm{~s}$ další zásah CLER s parametrem 0 (vypnutí vedení). Do grafiky (4.) se zadají proměnné PG a NT (činný výkon generátoru a výkon turbíny) a zátěžný úhel DELT.

Obr. 3.2-6 ukazuje průběhy zátěžného úhlu a trajektorie kývání pro všechny př́ípady.
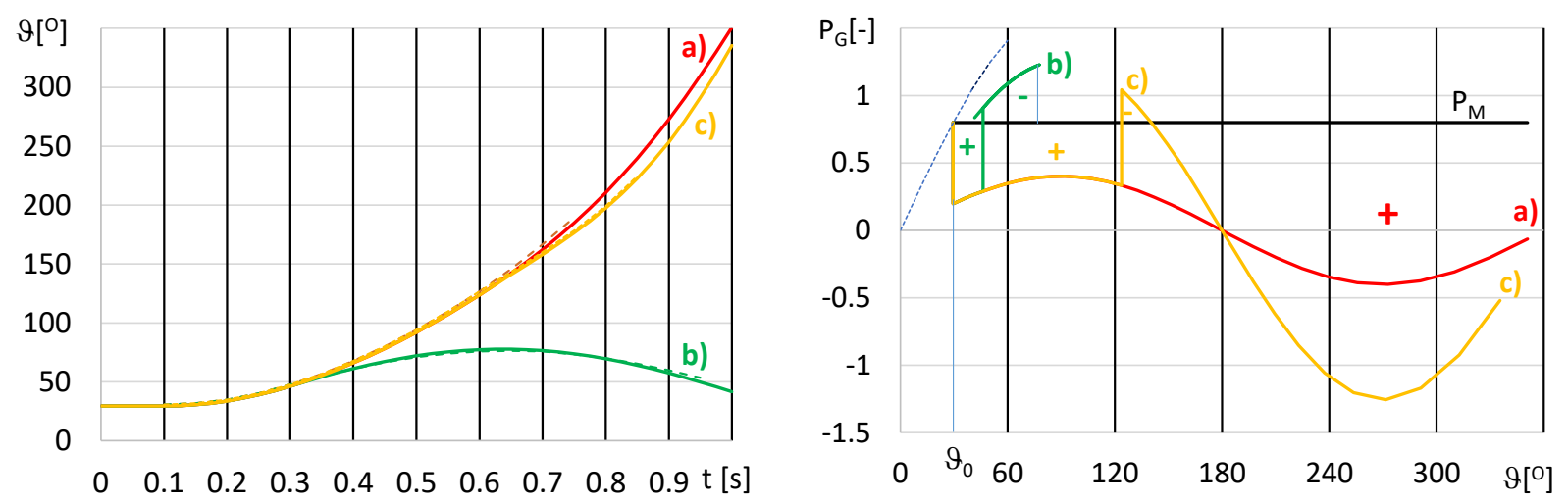

Obr. 3.2-6 Průběhy zátěžného úhlu a trajektorie kývání $P G=f(\vartheta)$

Simulované průběhy zátěžného úhlu, rozlišené barevně pro případy a), b) a c), odpovídají těm spočítaným ve skriptu ruční integrací krok za krokem (ty jsou v grafu kresleny tenčí čárkovanou čarou). Z průběhů je jasně patrno, že př́ípady a) a c) jsou nestabilní.

To je dokumentováno i na trajektoriích kývání znázorněných vpravo. Začínají z úhlu $\vartheta_{0}$, který je dán průsečíkem výchozí výkonové charakteristiky (naznačena modře tečkovaně) s prímkou výkonu turbíny $P_{M}$. Pro selhání vypínače v př́ípadě a) je červená trajektorie pod prŕmkou $\mathrm{P}_{\mathrm{M}}$, sleduje výkonovou charakteristiku $\mathrm{P}_{\mathrm{EZ}}$ a chybí zde brzdná plocha. $\mathrm{V}$ případě c) dlouhého vypínání zkratu přechází oranžová trajektorie po vypnutí na výkonovou charakteristiku $\mathrm{P}_{\mathrm{E} 1}$, ale brzdná plocha (-) je ve srovnání s akcelerační (+) velmi malá a nestačí na dobrzdění rotoru. V případě b) včasného vypnutí zkratu je brzdná plocha (-) větší než akcelerační (+) a průběh je stabilní. 


\section{Př́klad 3-5}

V soustavě z Obr. 3.1-2 vznikl uprostřed vedení V1B trojpólový zkrat. Zjistěte mezní dobu trvání zkratu pro dva př́ípady:

a) pro turbogenerátor s hladkým rotorem s parametry z Obr. 3.1-2

b) pro hydrogenerátor s vyniklými póly s parametry $x_{d}=0.31, x_{q}=0.65, \mathrm{~T}_{M}=6 \mathrm{~s}$.

\section{$\underline{\text { Řšení }}$}

Př́ípad b) vychází z př́kladu 3.5.1 ze skripta VUT v Brně [24] (str. 197).

Vysvětlíme napřed rozdíly mezi oběma konstrukcemi na fázorovém diagramu.

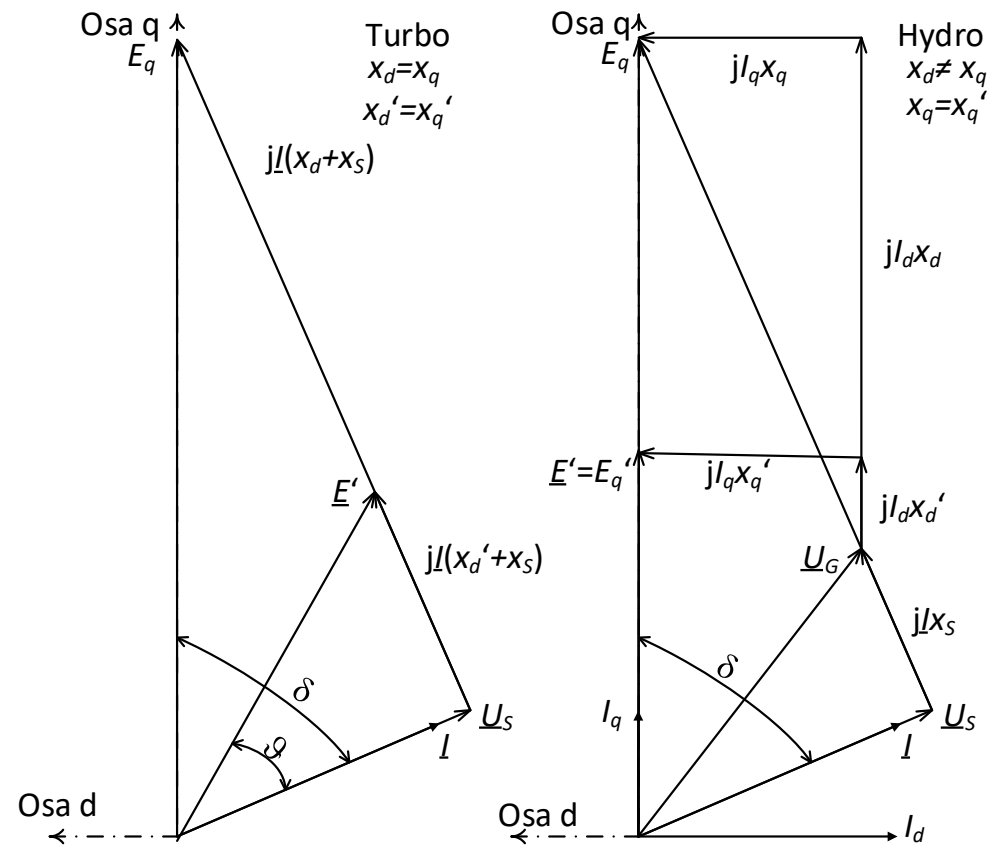

Obr. 3.2-7 Zjednodušený fázorový diagram pro turbogenerátor (vlevo) a hydrogenerátor (vpravo)

V obou př́padech pracují generátory do tvrdé sítě $\mathrm{s}$ napětím $U_{\mathrm{S}}=1$ a dodávají do ní jen činný výkon $\mathrm{P}_{\mathrm{n}}(I=0.8)$. Fázor $\underline{U}_{\mathrm{S}}$ určuje referenční osu, ke které se vztahují zátěžné úhly.

U turbogenerátoru jsme pro zjednodušení předpokládali magnetickou symetrii, tj. rovnost synchronních i přechodných reaktancí v podélné a prř́čné ose. Pro zjednodušené výpočty platí pro činný výkon generátoru dodávaný do tvrdé sítě vztah (3.1-1), kde se pro statickou stabilitu za $E$ dosadí $E_{\mathrm{q}}$, zátěžný úhel je $\delta$ a reaktance generátoru je synchronní $x_{d}$. Pro dynamickou stabilitu se za $E$ dosadí $E$, zátěžný úhel je $\vartheta$ a náhradní reaktance generátoru je přechodná $x_{d}$.

U hydrogenerátoru předpoklad magnetické symetrie neplatí. Vzhledem ke konstrukci rotoru $\mathrm{z}$ laminovaných plechů se rozptylové magnetické toky nemohou $\mathrm{v}$ příčné ose vyvinout a složka $E_{d}{ }^{6}$ je nulová. Výkon generátoru dodávaný do tvrdé sítě se mění podle vztahu:

$$
P_{E}=\frac{E U_{S}}{x_{G}+x_{S}} \sin \delta+\frac{U_{S}^{2}\left(x_{G}-x_{q}\right)}{2\left(x_{G}+x_{S}\right)\left(x_{q}+x_{S}\right)} \sin 2 \delta=P_{E \max } \sin \delta+P_{E 2 \max } \sin 2 \delta,
$$

kde $x_{S}$ je náhradní reaktance sítě. Pro statickou stabilitu za $E$ dosadí $E_{\mathrm{q}}$ a náhradní reaktance generátoru $x_{G}$ je synchronní $x_{d}$. Pro přechodnou stabilitu za $E$ dosadí $E_{\mathrm{q}}$ 'a náhradní reaktance generátoru je přechodná $x_{d}$.

Zbývá vysvětlit rozdíly v mechanické časové konstantě $T_{M}$, která se spočte ze setrvačného momentu $\left(\mathrm{GD}^{2}\right)$ generátoru a turbíny. U turbogenerátorů jde o jedno- nebo dvoupólové stroje a setrvačný moment generátoru je menší než turbíny. U hydrogenerátorů se jedná o vícepólové stroje a setrvačný moment generátoru je mnohem větší než turbíny. Celkově vycházejí mechanické časové konstanty soustrojí s hydrogenerátory menší (6 - 9 s) než u soustrojí s turbogenerátory $(7-12 \mathrm{~s})$. 
Nyní provedeme analytický výpočet kritického úhlu, při kterém je nutno zkrat vypnout, aby byla zachována stabilita (rovnost velikostí brzdicí a akcelerační plochy):

$$
\int_{\Theta_{0}}^{\Theta_{C}}\left(P_{M}-P_{E Z}\right) d \Theta=-\int_{\Theta_{C}}^{\Theta_{2}}\left(P_{M}-P_{E 1}\right) d \Theta,
$$

kde za integrační proměnnou $\Theta$ a výkon $P_{\mathrm{E}}$ dosazujeme $\vartheta$ a závislost ( 3.1 1) pro turbogenerátor a úhel $\delta$ a závislost ( 3.27 ) pro hydrogenerátor (charakteristiky jsou různé pro oba typy).

Řešením integrální rovnosti pro turbogenerátor získáme vztah pro kritický úhel:

$$
\vartheta_{C}=\arccos \left(\frac{P_{M}\left(\vartheta_{2}-\vartheta_{0}\right)+P_{E \max 1} \cos \left(\vartheta_{2}\right)-P_{E \max Z} \cos \left(\vartheta_{0}\right)}{P_{E \max 1}-P_{E \max Z}}\right) .
$$

Pro turbogenerátor máme amplitudy $P_{E}$ spočteny $\mathrm{v}$ předchozím př́íladu. Počáteční a koncový úhel dopočítáme $\vartheta_{0}=\arcsin \left(P_{M} / P_{E m a x 0}\right)=29.5^{\circ}$ a $\vartheta_{2}=180-\arcsin \left(P_{M} / P_{E m a x 1}\right)=140.5^{\circ}$ a dosazením do (3.2-9) zjistíme $\vartheta_{\mathrm{C}}=74.5^{\circ}$.

Pro hydrogenerátor spočítáme nejprve náhradní parametry. Hodnoty reaktancí generátoru přepočtené na stranu $110 \mathrm{kV}$ jsou $x_{q}=1.21 \cdot 0.65=0.7865$ a $x_{d}=1.21 \cdot 0.31=0.3751$. Náhradní reaktance sítě je z Obr. 3.2-2 pro výchozí stav rovna $x_{S}=x_{T 1}+x_{S} / 2+x_{T 2}=0.4635$.

Pro výchozí zátěžný úhel platí $\mathrm{z}$ fázorového diagramu (Obr. 3.2-7 vpravo) $\delta_{0}=\operatorname{arctg}\left(I\left(x_{q}+x_{S}\right) / U_{S}\right)=45^{\circ}$. Z fázorového diagramu rovněž zjistíme náhradní reaktanci $E_{q}{ }^{\prime}=U_{S} \cos \delta_{0}+I \sin \delta_{0}\left(x_{d}{ }^{\circ}+x_{S}\right)=1.181$.

Další výpočet je mnohem složitější. Rovnice pro $\delta_{1}$ a $\delta_{2}$, nemají analytické řešení, takže byly vyřšseny graficky. Následující obrázek ukazuje výkonové charakteristiky.
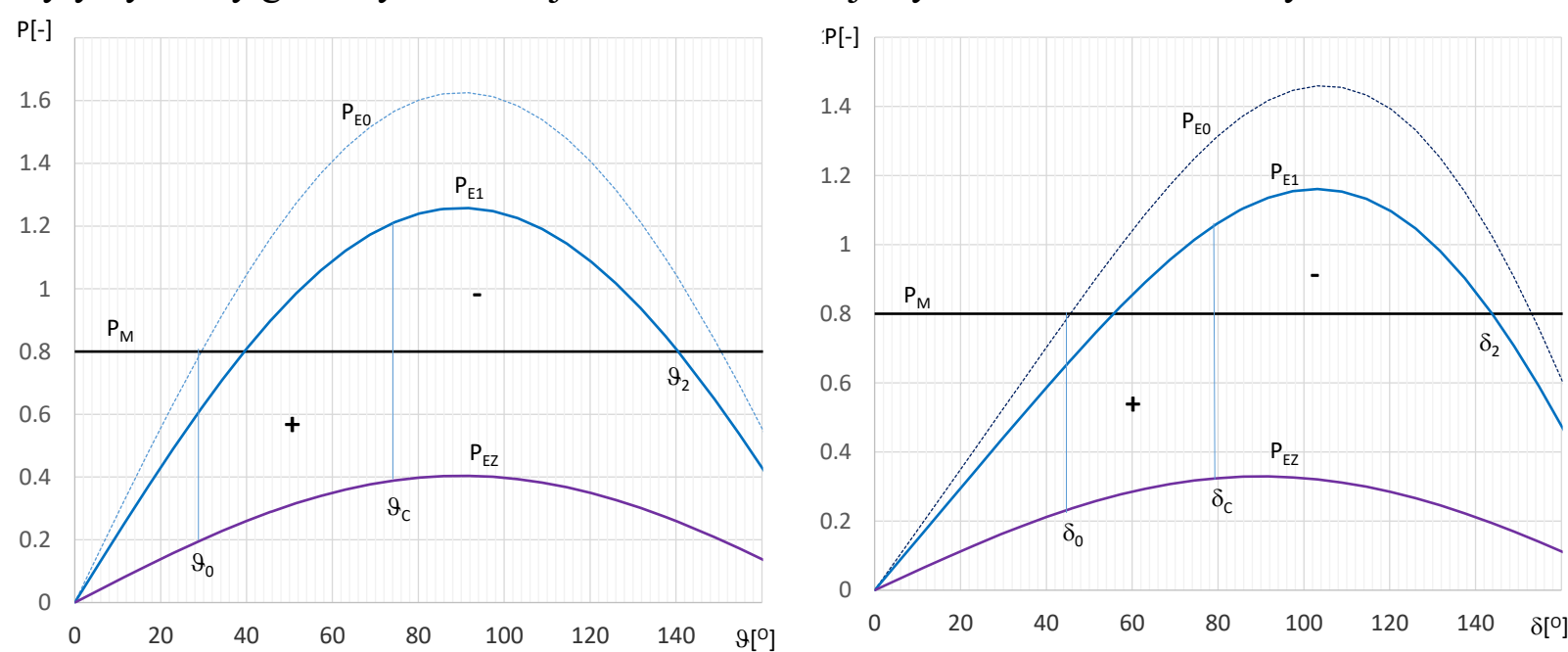

Obr. 3.2-8 Výkonové charakteristiky pro turbogenerátor (vlevo) a hydrogenerátor (vpravo)

Pro hydrogenerátor byla pro zkrat zanedbána druhá složka výkonu ve vztahu (3.2-7), takže fialová charakteristika má čistě sinusový průběh $\left(P_{E 2 \max Z}=0\right.$ - odvození přesných vztahů pro náhradní reaktanci sítě by bylo značně složité).

Všechny parametry a proměnné potřebné pro konstrukci charakteristik, spočtené úhly a CCT (podle vztahu ( 3.2-6)) jsou přehledně shrnuty v následující tabulce.

Tab. 3.2-2 Parametry výkonových charakteristik (v p.j. na $S_{v}=62.5$ MVA) a spočtené hodnoty

\begin{tabular}{|l|l|l|l|l|c|c|c|c|l|l|l|l|l|}
\hline & $E$ & $T_{M}$ & $P_{M}$ & $P_{E \max 0}$ & $P_{E 2 \max 0}$ & $P_{E \max Z}$ & $P_{E \max 1}$ & $P_{E 2 \max 1}$ & $\Theta_{0}$ & $\Theta_{\mathrm{C}}$ & $\Theta_{2}$ & $P_{A s}$ & $\mathrm{CCT}$ \\
\hline Turbo & 1.148 & 12.5 & 0.8 & 1.626 & - & 0.404 & 1.258 & - & 29.5 & 74.5 & 140.5 & 0.495 & $0.355 \mathrm{~s}$ \\
\hline Hydro & 1.179 & 6 & 0.8 & 1.406 & -0.204 & 0.329 & 1.128 & -0.141 & 45 & 79.7 & 144 & 0.519 & $0.211 \mathrm{~s}$ \\
\hline
\end{tabular}

Pro hydrogenerátor vychází CCT menší (je méně stabilní). Výkonová charakteristika je méně příznivá (akcelerační výkon $P_{A s}$ je větší, naopak rozdíl úhlů $\Theta_{\mathrm{C}}-\Theta_{0}$ je menší), ale hlavní roli hraje nižší setrvačnost. 
Nyní provedeme simulační výpočty mezní doby trvání zkratu (CCT) s přesnějšími modely generátorů. Lze vyjít z předchozího př́kladu 3-4, použít stejný chod sítě SMIB4111 a pro turbogenerátor $\mathrm{v}$ případu a) použít dynamické modely z př́kladu 3-2 (přesný model generátoru PARK se sadou typových parametrů P50PAR a standardní model buzení).

Hledání CCT simulačními výpočty tradičním způsobem je dosti pracné, protože se musí výpočty několikrát opakovat, než se dojde do stavu, kdy je jeden výpočet stabilní a další už nestabilní. Pro zefektivnění práce byl v simulátoru MODES implementován algoritmus, který umožňuje spočítat CCT na jedno spuštění simulace. Algoritmus je založen na výpočtu kinetické energie rotoru $\mathrm{W}$ od okamžiku zkratu $\mathrm{t}_{0}$ do ukončení prvního kyvu výkonu $\mathrm{v}$ čase $\mathrm{t}_{1}$ po vypnutí zkratu. Pro stabilní průběh musí být tato energie záporná:

$$
W=\int_{t_{0}}^{t_{1}} P_{A} d t<0 .
$$

Na jeden simulační výpočet se provede několik zkratů, zjistí se poslední stabilní a první nestabilní průběh a ze spočtených kinetických energií $\mathrm{W}_{\mathrm{S}}$ a $\mathrm{W}_{\mathrm{N}}$ se lineárně aproximuje CCT:

$$
\begin{gathered}
W_{S}=\int_{t_{0}}^{t_{1}} P_{A} d t, \quad W_{N}=\int_{t_{0}}^{t_{1}^{\prime}} P_{A} d t, \\
C C T=T_{S}-\frac{W_{S}}{\left(W_{N}-W_{S}\right)}\left(T_{N}-T_{S}\right) .
\end{gathered}
$$

Situaci vysvětluje následující obrázek (podrobněji je metoda popsána v [29]).
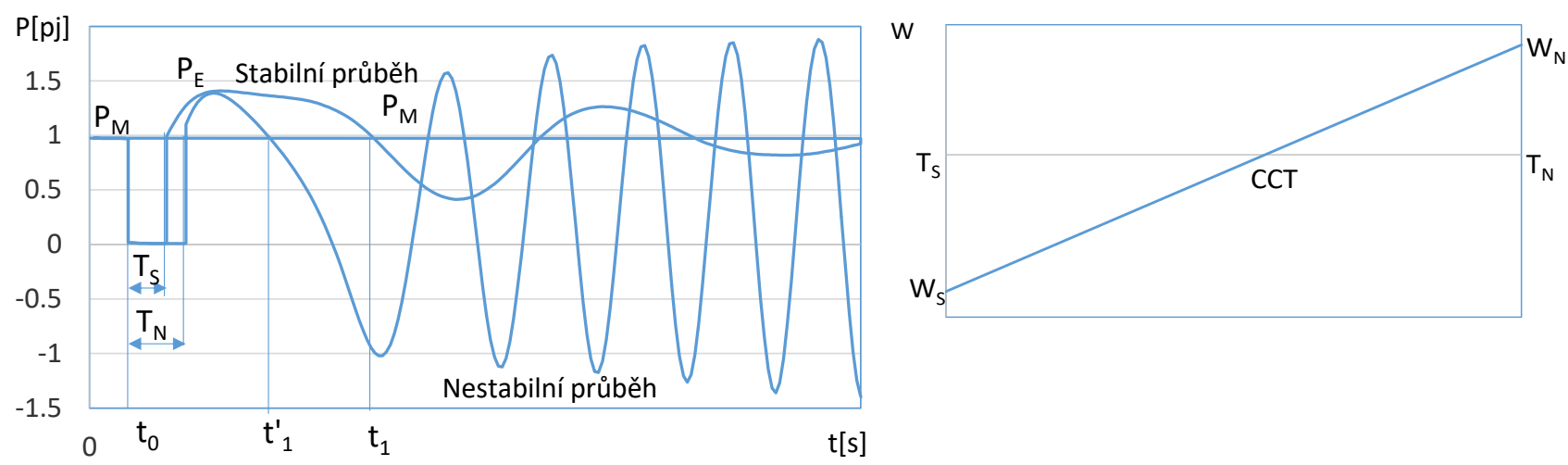

Obr. 3.2-9 Výkony generátoru pro stabilní a nestabilní průběh (vlevo) a aproximace CCT z energií W

Dobu výpočtu prodloužíme na $2 \mathrm{~s}$ a zadáme požadavek na návrat času po zásahu SNAP do výchozí hodnoty a požadavek na výpočet CCT (‥).

Do scénáře (3.) se zadá $\mathrm{v}$ čase $\mathrm{t}=0 \mathrm{~s}$ pro objekt Čas zásah SNAP s parametrem 0 , který uloží výchozí stav soustavy $\mathrm{v}$ tomto čase. Pak se $\mathrm{v}$ čase $\mathrm{t}=0.1 \mathrm{~s}$ zadá trojfázový zkrat na vedení V1B zásahem FOUL s parametry 50 (zkrat v 50 \% délky vedení) a 0 (kovový zkrat). Z výsledků analytického výpočtu víme, že CCT pro turboalternátor vychází kolem $0.35 \mathrm{~s}$, takže dobu vypnutí pro stabilní průběh zadáme na $\mathrm{t}=0.4 \mathrm{~s}$ zásahem CLER s parametrem 0 (vypnutí vedení). Těsně před skončením doby výpočtu zadáme $\mathrm{v}$ čase $\mathrm{t}=1.975 \mathrm{~s}$ další zásah SNAP s parametrem 1 , který načte výchozí stav soustavy. Pak se zadá provedení druhého zkratu v čase $\mathrm{t}=0.1 \mathrm{~s}$ zásahem FOUL se stejnými parametry a nakonec vypnutí zkratu zásahem CLER v čase $\mathrm{t}=0.5 \mathrm{~s}$ (o němž víme, že průběh bude nestabilní).

Do grafiky (4.) se zadá do prvního grafu proměnná WE pro generátor G1 (pro výpočet kinetické energie prvního kyvu). 
Obr. 3.2-10 ukazuje výsledky simulačního výpočtu pro stabilní a nestabilní případ.
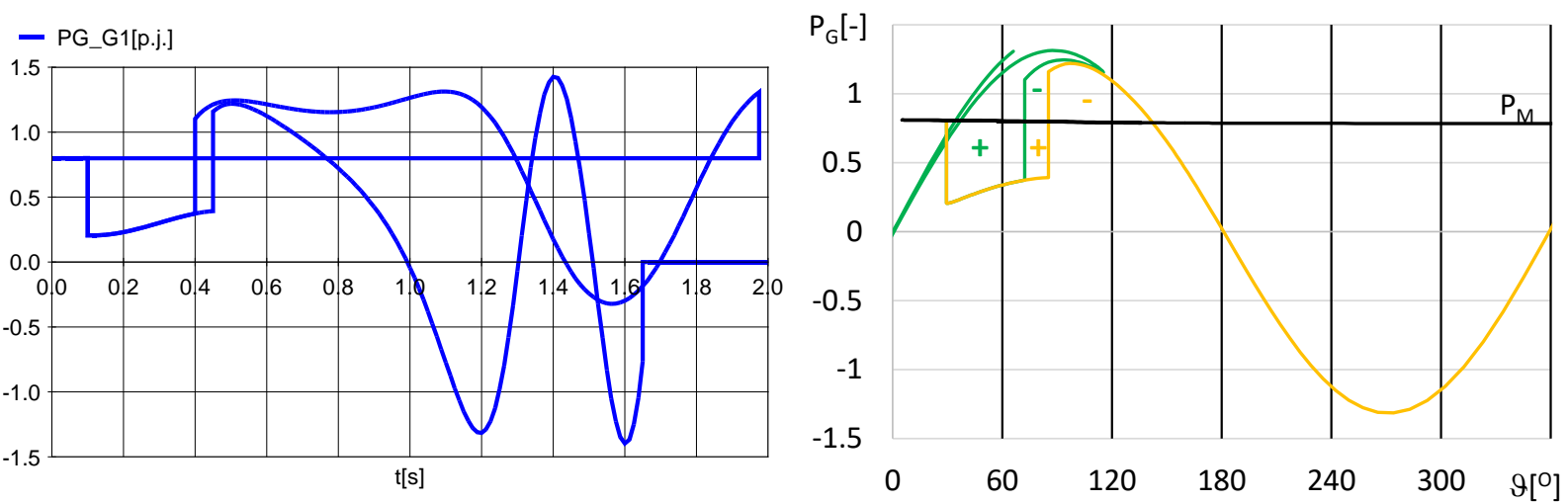

Obr. 3.2-10 Průběhy činného výkonu (vlevo) a trajektorie kývání $\mathbf{P}_{\mathrm{G}}=\mathbf{f}(\vartheta)$ (vpravo) pro turbogenerátor

$\mathrm{Na}$ časovém průběhu činného výkonu je vidět pokles činného výkonu při zkratu. Po vypnutí zkratu dochází ke skokové změně výkonu a pro kratší dobu trvání zkratu $0.3 \mathrm{~s}$ je průběh stabilní (brzdná plocha je velká), první kyv končí pro t $=1.3 \mathrm{~s}$. Při prodloužení doby trvání zkratu o $50 \mathrm{~ms}$ je průběh již nestabilní a po druhém prokluzu pólů je generátor automaticky vypnut. Na obrázku vpravo jsou trajektorie kyvů činného výkonu v závislosti na zátěžném úhlu $\vartheta^{1}$. Stabilní trajektorie je kreslená zeleně a nestabilní oranžově. CCT spočtený podle aproximačního vztahu $(3.2-11)$ je $0.335 \mathrm{~s}$.

Pro hydroalternátor je potřeba změnit parametry generátoru. Použijeme připravenou sadu H50PAR a vyměníme ji pomocí Editoru modelů bloku (7.) za původní parametry.

Tab. 3.2-3 Typové parametry generátoru pro Parkův model hydroalternátoru

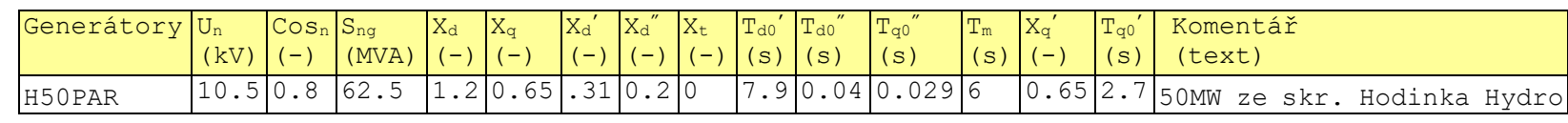

Z výsledků analytického výpočtu víme, že CCT pro hydroalternátor je kratší, proto ještě upravíme dobu trvání obou zkratů. Nejprve pomocí scénáře (…) necháme (beze změn) udělat novou variantu. A pak v textovém režimu ( $\mathrm{z}$ menu Modifikovat při nezaškrtnuté položce Dialogy) opravíme čas vypnutí prvního zkratu z 0.4 na $0.3 \mathrm{~s}$ a druhého z 0.5 na $0.35 \mathrm{~s}$

Následující obrázek ukazuje výsledky simulačního výpočtu zkratu pro hydrolternátor.
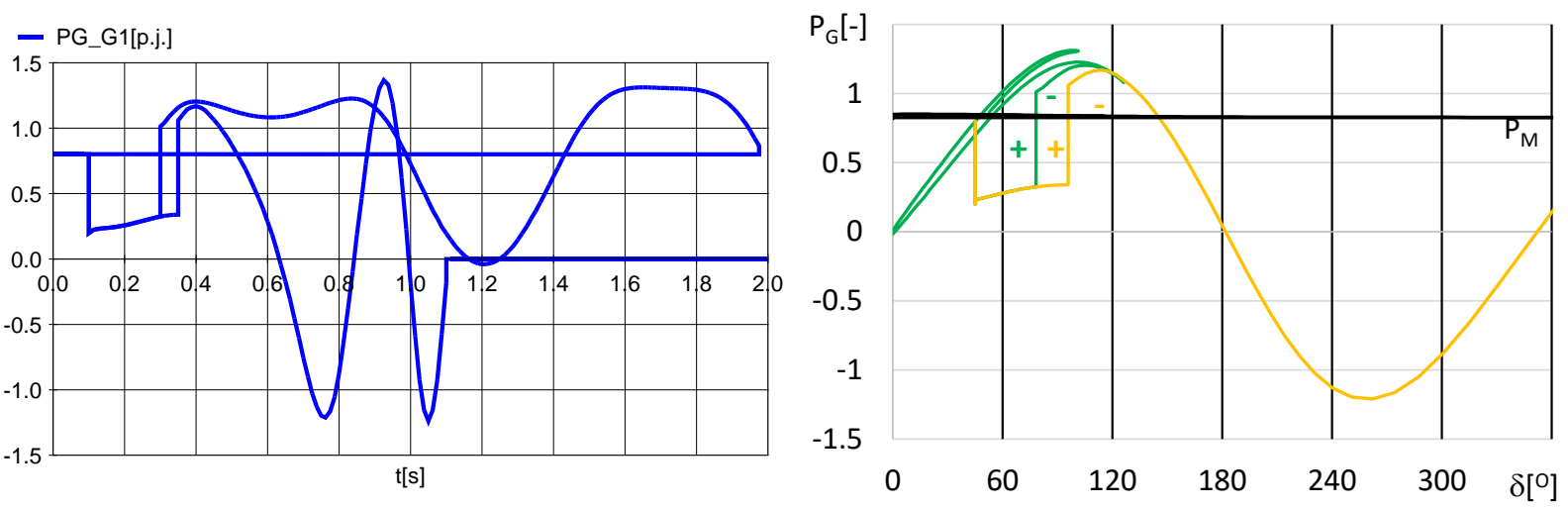

Obr. 3.2-11 Průběhy činného výkonu (vlevo) a trajektorie kývání $P_{G}=f(\delta)$ (vpravo) pro hydrogenerátor

Oproti turbogenerátoru končí první kyv výkonu pro kratší dobu trvání zkratu $0.2 \mathrm{~s}$ dříve, před $\mathrm{t}=1 \mathrm{~s}$, což je dáno nižší setrvačností hydroalternátoru a rychlejším nárůstem $\delta$. Stabilní trajektorie v grafu vpravo je kreslená zeleně a nestabilní oranžově. CCT spočtený podle aproximačního vztahu je 0.229 s.

\footnotetext{
${ }^{1}$ tento úhel MODES přímo nezobrazuje, proto je potřeba ho dopočítat ze složek fázoru $\vartheta=\delta+\operatorname{arctg}\left(E_{d}{ }^{\circ} / E_{q}{ }^{\circ}\right)$
} 
Na závěr řešení příkladu ještě zobrazíme trajektorie kyvi̊ pro nejdelší doby trvání zkratů $0.3125 \mathrm{~s}$ pro turbo a $0.2125 \mathrm{~s}$ pro hydrogenerátor.
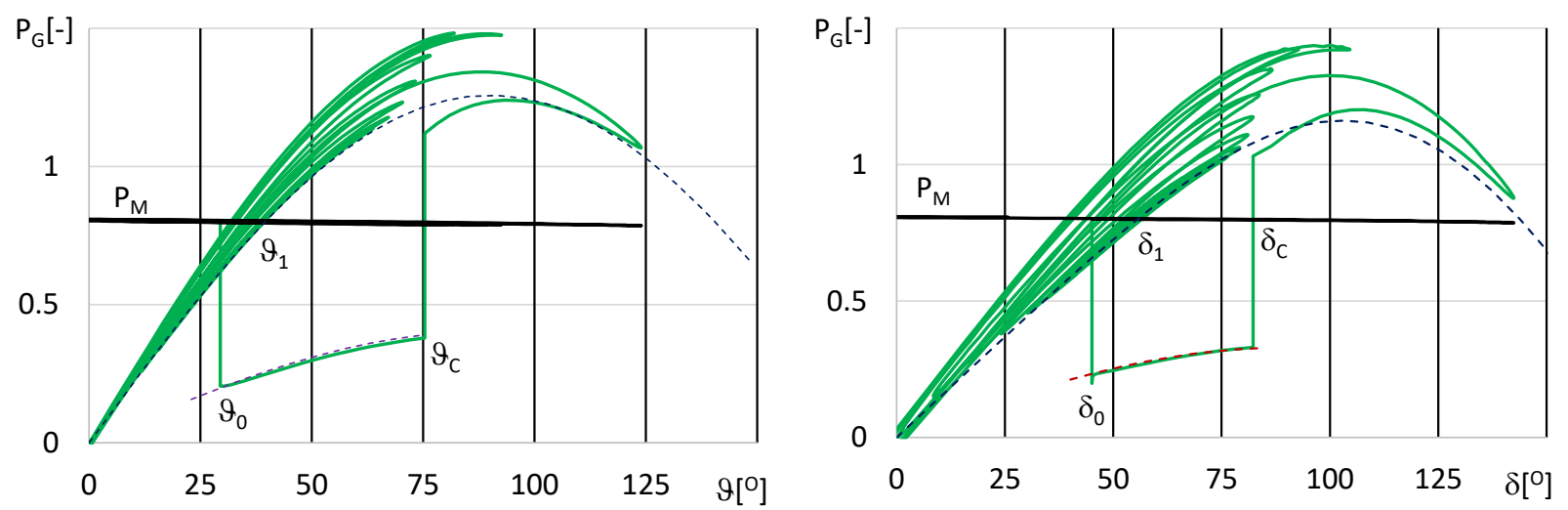

Obr. 3.2-12 Trajektorie kývání pro turbogenerátor (vlevo) a hydrogenerátor (vpravo) a CCT

V grafech jsou zobrazeny čárkovaně i analyticky spočtené výkonové charakteristiky pro zkrat a po vypnutí zkratu podle rovnic (3.1-1) pro turbogenerátor a (3.2-7) pro hydrogenerátor (odpovídají i průběhům na Obr. 3.2-8). Pro zkrat si výkonové charakteristiky odpovídají přesně. Shoda pro první kyv výkonu po vypnutí zkratu je vcelku dobrá, takže náhrada generátoru přechodovou charakteristikou je oprávněná. Při dalších kyvech už se přechodová charakteristika od reálných kyvů dosti odchyluje. Po odeznění přechodných dějů v rotorových obvodech generátoru a regulačních dějů v budicím systému se reálné kyvy opět přiblíží přechodové charakteristice. Zbývá dodat, že nejmenší časová jednotka v simulačním výpočtu je integrační krok, v našem př́padě 12.5 ms (zadávaný v parametrech výpočtu (4․)). Nejdelší doby trvání zkratu jsou tedy násobky tohoto kroku.

Dosud jsme vyšetřovali úhlovou stabilitu pro trojfázový zkrat. K těm ovšem dochází jen výjimečně a častější jsou zkraty postihující jednu nebo dvě fáze. Ty ale ohrožují úhlovou stabilitu mnohem méně než nejtěžší porucha typu tř́fázového zkratu. Ukážeme to na následujícím př́kladu, který je převzat ze skript VUT v Brně [24] (Příklad 3.5.5 str. 205).

\section{Př́ḱlad 3-6}

V soustavě z Obr. 3.2-13 vznikl na vedení V1B zkrat u uzlu 2. Zjistěte mezní dobu trvání zkratu CCT pro tyto typy zkratů:

a) tř́fázový,

b) dvoufázový zemní,

c) dvoufázový a

d) jednofázový.

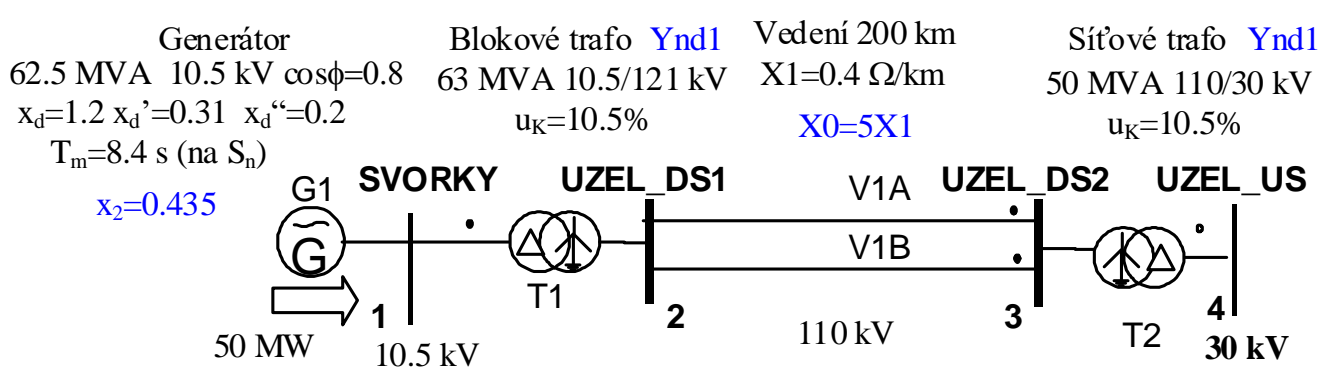

Obr. 3.2-13 Model soustavy pro výpočet nesymetrických poruch

Model odpovídá soustavě z Obr. 3.1-2, jen jsou doplněny parametry pro zpětnou a netočivou složku (uvedeny modře) a upraveny parametry generátoru, aby odpovídaly zadání př́kladu ve skriptu [24]. 


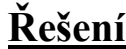

Nejprve, podobně jako ve skriptu, spočítáme hodnoty CCT pro jednotlivé zkraty zjednodušeným výpočtem, kdy nahradíme generátor elektromotorickou silou $\mathrm{E}^{`}$ za přechodnou reaktancí, zjistíme přechodné výkonové charakteristiky, kritické úhly a CCT.

Pro zjištění amplitud přechodných charakteristik nejprve spočítáme výsledné reaktance pro výchozí stav, zkraty a stav po vypnutí poruchy. Použijeme výpočet v poměrných hodnotách podle náhradních schémat na Obr. 3.2-14.

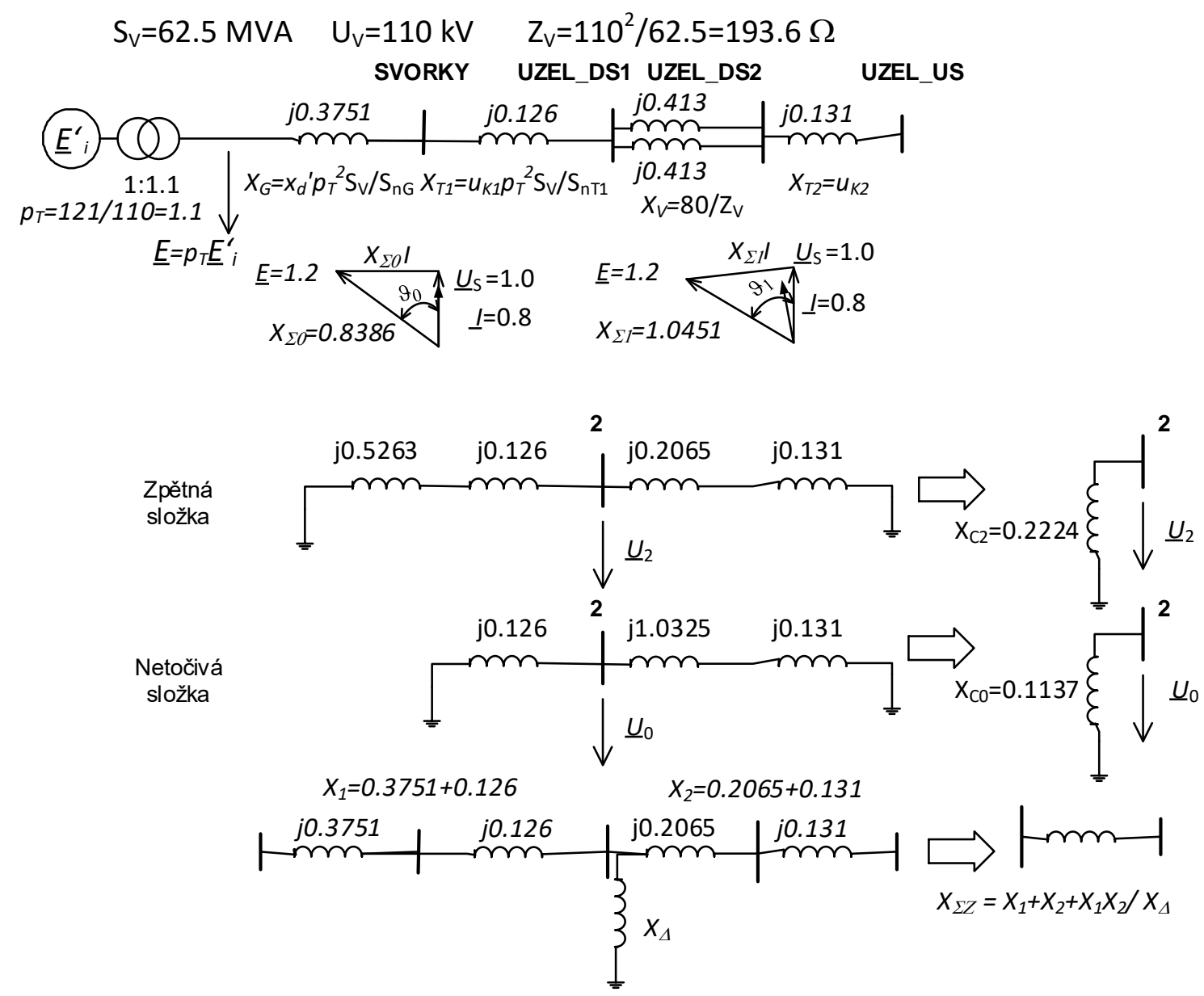

Obr. 3.2-14 Náhradní schéma pro souslednou, zpětnou a netočivou složkovou soustavu (pro zkrat v uzlu 2)

V horní části obrázku je náhradní schéma pro souslednou složkovou soustavu. Pod ním jsou dva fázorové diagramy pro stav před poruchou (vlevo) a po vypnutí poruchy včetně jednoho z paralelních vedení (vpravo).

Podle metody souměrných složek (podrobněji viz kniha [19] str. 80 a 107) lze vliv nesymetrických zkratů modelovat připojením přídavné impedance mezi místo poruchy a zem. Přídavná impedance $\mathrm{Z}_{\Delta}$ se spočte $\mathrm{z}$ celkových impedancí zpětné $\mathrm{Z}_{\mathrm{C} 2}$ a netočivé $\mathrm{Z}_{\mathrm{C} 0}$ složkové soustavy podle typu zkratu:

$$
\mathrm{Z}_{\Delta 3 \mathrm{f}}=0, \quad \mathrm{Z}_{\Delta 2 \mathrm{f}}=\mathrm{Z}_{\mathrm{C} 2}, \quad \mathrm{Z}_{\Delta 1 \mathrm{f}}=\mathrm{Z}_{\mathrm{C} 2}+\mathrm{Z}_{\mathrm{C} 0}, \quad \mathrm{Z}_{\Delta 2 \mathrm{fz}}=\mathrm{Z}_{\mathrm{C} 2} \mathrm{Z}_{\mathrm{C} 0} /\left(\mathrm{Z}_{\mathrm{C} 2}+\mathrm{Z}_{\mathrm{C} 0}\right) .
$$

V našich výpočtech jsme zanedbávali odpory, takže impedance lze nahradit reaktancemi.

Z náhradních reaktancí před a po poruše $X_{\Sigma 0}$ a $X_{\Sigma 1}$ dopočítáme podle (3.1-1) amplitudy výkonových charakteristik: $P_{E \max 0}=1.2 \cdot 1 / 0.839=1.436, P_{E \max l}=1.2 \cdot 1 / 1.045=1.152$. Počáteční a koncový úhel snadno dopočítáme:

$$
\vartheta_{0}=\arcsin \left(P_{M} / P_{\text {Emax } 0}\right)=33.8^{\circ} \text { a } \vartheta_{2}=180-\arcsin \left(P_{M} / P_{E m a x l}\right)=136^{\circ} .
$$


Pro výpočet náhradní reaktance během zkratů použijeme náhradní schéma z Obr. 3.2-14 dole, kde se do uzlu 2 připojila reaktance $X_{\Delta}$ a transfigurací $Y \rightarrow \Delta$ se spočetla reaktance $X_{\Sigma Z}$.

Tab. 3.2-4 ukazuje $\mathrm{v}$ přehledu reaktance a veličiny potřebné pro výpočet kritického úhlu $\vartheta_{\mathrm{C}}$ a CCT podle rovnic (3.2-9) a (3.2-6).

Tab. 3.2-4 Parametry výkonových charakteristik během zkratu a spočtené hodnoty

\begin{tabular}{|l|l|l|l|l|l|l|}
\hline Zkrat & $X_{\Delta}$ & $X_{\Sigma \mathrm{Z}}$ & $P_{\operatorname{Emaxz}}$ & $\vartheta_{\mathrm{C}}$ & $P_{A s}$ & $\mathrm{CCT}$ \\
\hline Tř́fázový & 0 & $\infty$ & 0 & $58.8^{\circ}$ & 0.8 & $0.17 \mathrm{~s}$ \\
\hline Dvoufázový zemní & 0.075 & 3.086 & 0.39 & $69^{\circ}$ & 0.492 & $0.26 \mathrm{~s}$ \\
\hline Dvoufázový & 0.222 & 1.6 & 0.753 & $94^{\circ}$ & 0.266 & $0.46 \mathrm{~s}$ \\
\hline Jednofázový & 0.336 & 1.34 & 0.897 & $125.5^{\circ}$ & 0.004 & $4.5 \mathrm{~s}$ \\
\hline
\end{tabular}

Následující obrázek ukazuje výkonové charakteristiky pro jednotlivé zkraty.

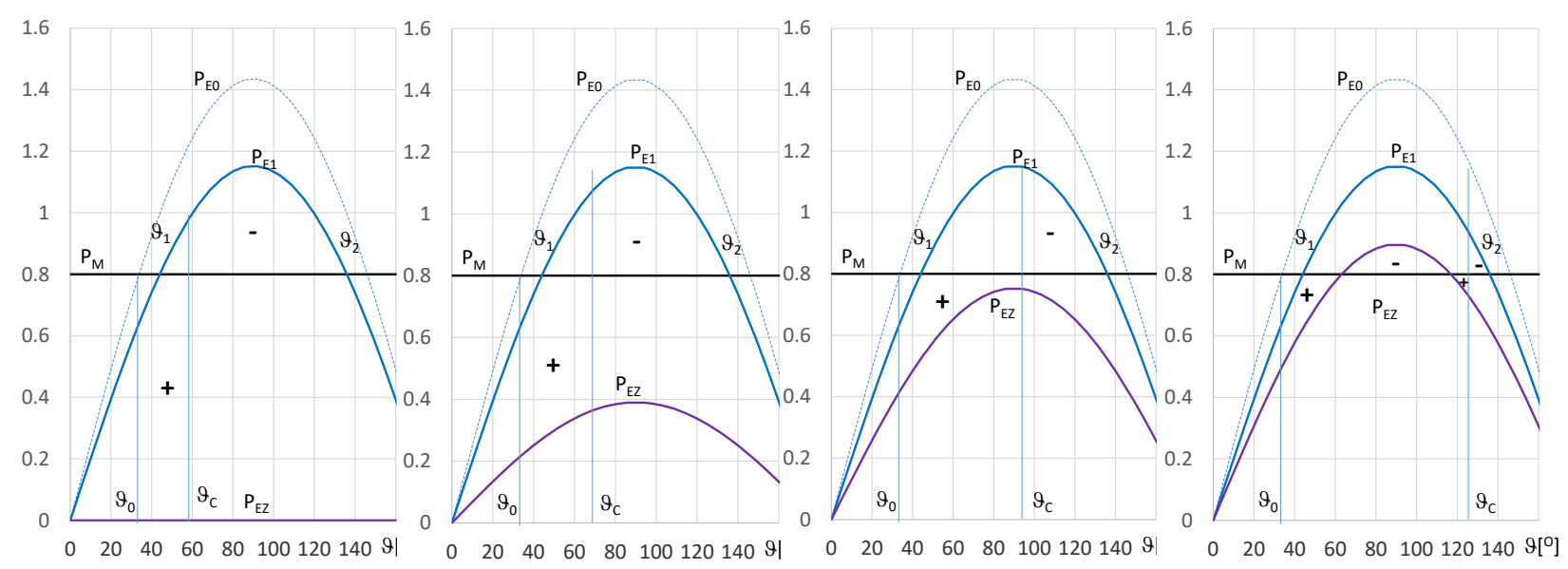

Obr. 3.2-15 Výkonové charakteristiky pro tř́fázový, dvoufázový zemní, dvoufázový a jednofázový zkrat

Nyní provedeme simulační výpočty mezní doby trvání zkratu (CCT) s přesnějším modelem generátoru. Lze vyjít z předchozího př́íladu 3-5. Pro výpočet nesymetrických poruch je nutno doplnit parametry netočivé složky pro vedení a trafa. Můžeme to udělat v textovém režimu př́mo do vstupního souboru SMIB4__1.VET podle tohoto výpisu:

\begin{tabular}{|c|c|c|c|c|c|c|c|c|c|c|c|c|c|c|c|c|c|c|c|c|c|c|c|}
\hline \# & $\begin{array}{l}\text { Jmeno } \\
\text { vetve }\end{array}$ & $\begin{array}{r}\mathrm{Uz} \\
\mathrm{PoC}\end{array}$ & $\begin{array}{l}1 \\
\text { Kon }\end{array}$ & $\mathrm{R}$ & 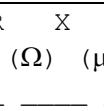 & $\begin{aligned} B \\
\text { S) }\end{aligned}$ & $\begin{array}{l}\text { absp } \\
(-)\end{array}$ & $\begin{array}{l}\text { argp } \\
\text { (०) }(\end{array}$ & $\begin{array}{l}\text { Stav } \\
0 / 1)\end{array}$ & GPoc & $\begin{array}{l}B_{\text {Poc }} \\
(\mu S)\end{array}$ & GKon & $\begin{array}{r}\text { Bkon } \\
( \\
\end{array}$ & $\begin{array}{l}I / S_{\max } \\
(\mathrm{A} / \mathrm{MVA}) \\
\end{array}$ & $\begin{array}{l}R_{0} \\
(\Omega\end{array}$ & $\begin{array}{ll}\mathrm{x}_{0} & \mathrm{~B} \\
2) & (\end{array}$ & \multicolumn{2}{|c|}{$\begin{array}{l}\text { Bo Zap } \\
(\mu S) \quad(-)\end{array}$} & $\begin{array}{l}\text { Ge } \\
)^{\prime}\end{array}$ & \multicolumn{2}{|c|}{$\begin{array}{c}\mathrm{B}_{\mathrm{PO}} \mathrm{G}_{\mathrm{K} 0} \\
(\mu \mathrm{S})\end{array}$} & \multicolumn{2}{|c|}{$\begin{array}{l}\mathrm{BKO}_{\mathrm{KO}} \mathrm{HO} \\
\text { (hod) } \\
\text { Nvetx }\end{array}$} \\
\hline$\overline{1}$ & 'T & $\overline{1}$ & 2 & 0 & $\overline{24.4}$ & 0 & $0.90 \overline{9}$ & 0 & $\overline{1}$ & 0 & 0 & $\overline{0}$ & 0 & $\overline{63}$ & $\overline{0}$ & $2 \longdiv { 4 . 4 }$ & $\overline{0}$ & $\overline{-4}$ & 0 & $\overline{0}$ & $\overline{0}$ & 0 & 1 \\
\hline 2 & 'V1A' & 3 & 2 & 0 & 80 & 0 & 1.000 & 0 & 1 & 0 & 0 & 0 & 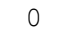 & 500 & 0 & 400 & 0 & 1 & 0 & 0 & 0 & 0 & 0 \\
\hline 3 & 'V1B' & 3 & 2 & 0 & 80 & 0 & 1.000 & 0 & 1 & 0 & 0 & 0 & 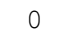 & 500 & 0 & 400 & 0 & 1 & 0 & 0 & 0 & 0 & 0 \\
\hline 4 & 'T2' & 4 & 3 & 0 & 25.41 & 0 & 1.000 & 0 & 1 & 0 & 0 & 0 & 0 & 50 & 0 & 25.41 & 10. & -4 & 0 & 0 & 0 & 0 & 1 \\
\hline
\end{tabular}

Doplněním modře vyznačených parametrů vzniknou rozšířené záznamy větví pro netočivou složku. $\mathrm{U}$ traf platí $\mathrm{X}_{0}=\mathrm{X}$ a kód Zap je: pro zapojení do hvězdy s izolovanou nulou (Yy nebo $\mathrm{Yd}$ )/ $\mathrm{Y}_{\mathrm{Z}} \mathrm{Y}_{\mathrm{Z}} / \mathrm{d} \mathrm{Y}_{\mathrm{Z}} / \mathrm{Y}_{\mathrm{Z}} \mathrm{d}$ (kde index z značí uzemněnou nulu hvězdy a d zapojení do trojúhelníka) 0/ 1/ -4/4. Zapojení vinutí transformátorů podstatně ovlivňuje velikost zkratových proudů. MODES neumožňuje zadat speciální reaktanci $\mathrm{X}_{2}$ pro netočivou složku.

V Editoru dynamických modelů (7.) pro generátor G1 vyměníme původní parametry P50PAR za novou sadu T50PAR odpovídající zadání příkladu:

Tab. 3.2-5 Typové parametry generátoru pro Parkův model turboalternátoru

\begin{tabular}{|c|c|c|c|c|c|c|c|c|c|c|c|c|c|c|c|c|}
\hline Generátory & $\begin{array}{l}\mathrm{U}_{\mathrm{n}} \\
(\mathrm{kV})\end{array}$ & $\begin{array}{l}\text { Cosn } \\
(-)\end{array}$ & $\begin{array}{l}\text { Sng } \\
\text { (MVA) }\end{array}$ & $\begin{array}{l}\mathrm{X}_{\mathrm{d}} \\
(-)\end{array}$ & $\begin{array}{c}X_{q} \\
(-)\end{array}$ & $\begin{array}{c}\mathrm{X}_{\mathrm{d}}^{\prime} \\
(-)\end{array}$ & $\begin{array}{c}\mathrm{Xd}_{\mathrm{d}}^{\prime \prime} \\
(-)\end{array}$ & \begin{tabular}{|c|}
$X_{t}$ \\
$(-)$
\end{tabular} & $\begin{array}{l}\mathrm{T}_{\mathrm{do}} \\
(\mathrm{S})\end{array}$ & $\begin{array}{l}\mathrm{T}_{\mathrm{do}}{ }^{\prime} \\
(\mathrm{S})\end{array}$ & $\begin{array}{l}\mathrm{T}_{\mathrm{q} 0}{ }^{\prime \prime} \\
(\mathrm{S})\end{array}$ & $\begin{array}{l}\mathrm{T}_{\mathrm{m}} \\
(\mathrm{s})\end{array}$ & $\begin{array}{l}\mathrm{X}_{\mathrm{q}}{ }^{\prime} \\
(-)\end{array}$ & $\begin{array}{l}\mathrm{T}_{\mathrm{q} 0}{ }^{\prime} \\
(\mathrm{s})\end{array}$ & $\begin{array}{l}\text { Komentár̆ } \\
\text { (text) }\end{array}$ & \\
\hline T50PAR & 10.5 & 0.8 & 62.5 & 1.2 & 1.2 & .31 & 0.31 & 0 & 7.9 & 0.04 & 0.029 & 8.4 & 0.31 & 2.7 & 50MW ze skr. Hodinka & Turbo \\
\hline
\end{tabular}

Podle zadání příkladu vytvoříme již známým postupem scénáře výpočtu pro případy trojfázového, dvoufázového zemního, dvoufázového a jednofázového zkratu zadáním zásahů FOUL, FSLG, F_LL a FDLG s parametry 100 a 0 (kovový zkrat v koncovém uzlu). 
Simulačními výpočty lze dospět pro první tři zkraty k následujícím CCT: $0.1625,0.2375$, 0.4375 s. Tyto časy jsou o něco kratší než podle zjednodušeného výpočtu (viz Tab. 3.2-4). Pro jednofázový zkrat nedošlo $\mathrm{k}$ asynchronnímu chodu ani při prodlužování doby zkratu. Je to dáno tím, že brzdicí plocha byla v simulačním výpočtu větší než akcelerační i během zkratu.

Obr. 3.2-16 ukazuje kyvy výkonu pro jednotlivé zkraty.
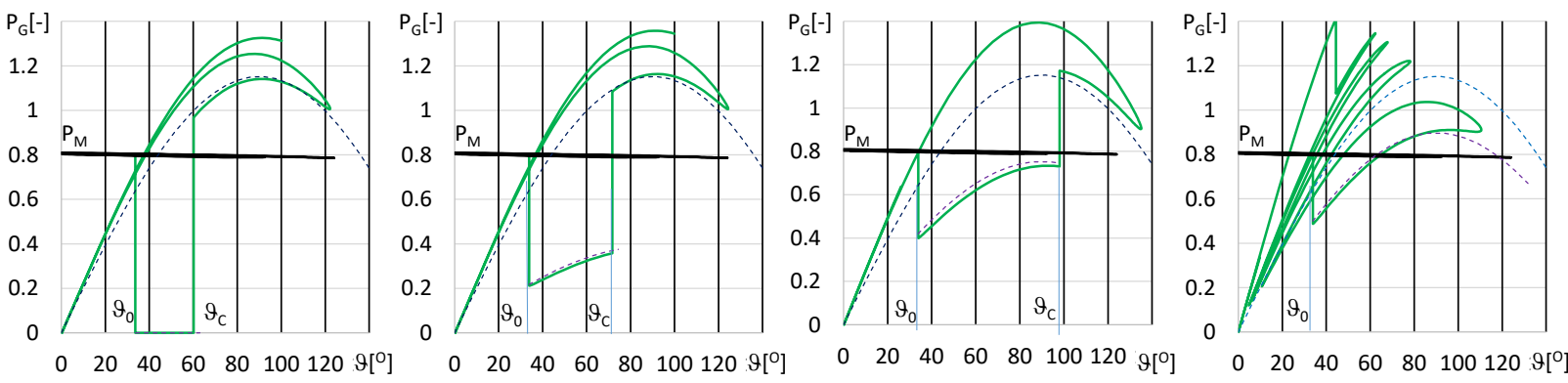

Obr. 3.2-16 Trajektorie kyvů výkonu pro trífázový, dvoufázový zemní, dvoufázový a jednofázový zkrat

V grafech jsou zobrazeny čárkovaně i analyticky spočtené výkonové charakteristiky. Shoda analytického i simulačního výpočtu pro první kyv výkonu je dobrá pro první tři typy zkratu. Pro jednofázový zkrat byla doba simulačního výpočtu prodloužena z 2 na $5 \mathrm{~s}$. Během dlouhotrvajícího zkratu generátor kýval, aniž by došlo $\mathrm{k}$ prokluzu pólů (přechodu do asynchronního chodu).

Jednofázové zkraty, ke kterým dochází nejčastěji, tedy představují pro úhlovou stabilitu nejmenší riziko. V praxi jsou pro jednofázové zkraty ochrany vybavovány automatikou opětného zapnutí, která po krátké pauze (kolem $1.2 \mathrm{~s}$ ) po vypnutí zkratu vedení znovu zapne. Během beznapětové pauzy dojde $\mathrm{k}$ zhasnutí zkratu a opětné zapnutí je úspěšné. Průběh takové poruchy je ukázán na následujícím obrázku, kde vedení V1B je vypnuto v krátkém čase $0.1 \mathrm{~s}$ a po $1.2 \mathrm{~s}$ znovu zapnuto.
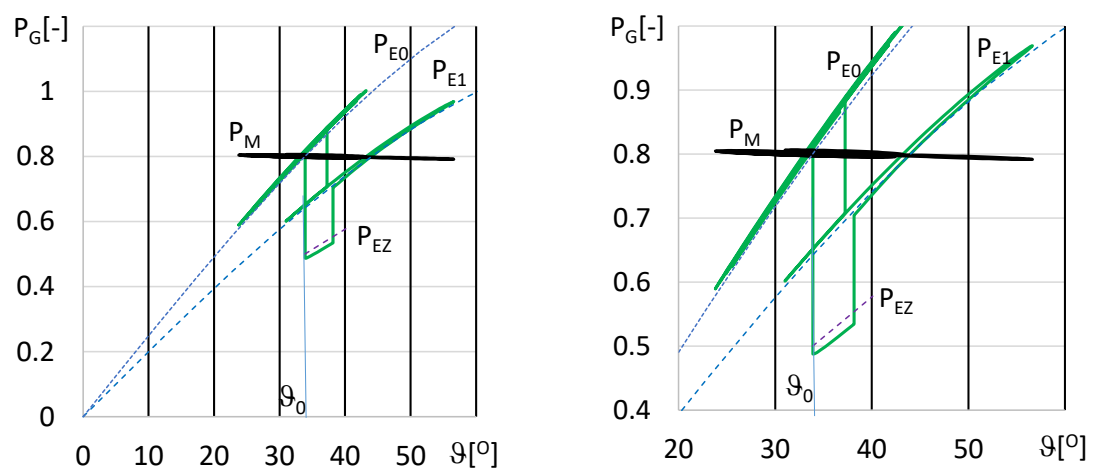

Obr. 3.2-17 Trajektorie kyvů výkonu pro jednofázový zkrat $s$ úspěšným opětným zapnutím

Během 0.1 s trvání zkratu se křivka výkonu pohybuje v blízkosti výkonové charakteristiky $\mathrm{P}_{\mathrm{EZ}}$, po vypnutí vedení přechází na charakteristiku $\mathrm{P}_{\mathrm{E} 1}$ a kývne přes $55^{\circ}$. Při zpětném kyvu je vedení zapnuto a generátor dokýve zpět do výchozí rovnovážné polohy dané zátěžným úhlem $\vartheta_{0}$.

Dosud jsme řešili stabilitu nejjednoduššího uspořádání jednostrojové soustavy, která zjednodušeně popisuje např́iklad vyvedení výkonu menšího zdroje do distribuční sítě, která je napájena $\mathrm{z}$ rozsáhlé přenosové soustavy $\mathrm{s}$ dostatečným zkratovým výkonem (při zkratu v distribuční síti se napětí napájecího uzlu přenosové soustavy př́iliš nemění).

Pokud ovšem tento předpoklad úplně neplatí, bude dynamické chování zdrojů složitější. Ukážeme si to na př́ípadu soustavy dvoustrojové, kde výkon zdrojů je srovnatelný. Př́ipad je opět inspirován př́kladem spolupráce dvou strojů ze skripta VUT v Brně [24] (str. 192). 


\section{Příklad 3-7}

V soustavě z Obr. 3.2-18 vznikl na vedení V1A jednofázový zkrat u uzlu 2. Zjistěte mezní dobu trvání CCT dočasného jednofázového zkratu (zkrat zmizí bez vypínání vedení).

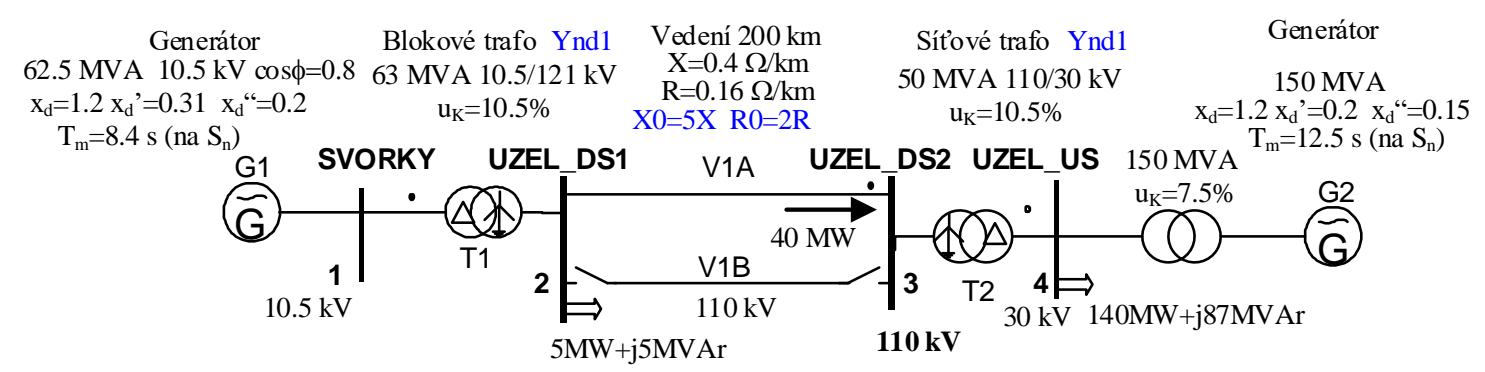

Obr. 3.2-18 Model dvoustrojové soustavy

Model odpovídá soustavě z Obr. 3.2-13 s vypnutým vedením V1B. Byly doplněny odpory vedení a odběry výkonů v uzlech 2 a 4 . Chod sítě byl upraven tak, aby vedením V1A tekl jen činný výkon $40 \mathrm{MW}$. Uzel 3 má jmenovité napětí $110 \mathrm{kV}$. Tvrdá sít' byla nahrazena synchronním generátorem o výkonu 150 MVA (včetně blokového trafa). Dynamické parametry byly převzaty z príkladu 3-2.

\section{$\underline{\text { Řšení }}$}

Tento příklad budeme řešit přímo simulačním výpočtem na dynamickém modelu. Vyjdeme z předchozího prríkladu s jednofázovým zkratem. Nejprve připravíme chod sítě. V Editoru chodu vypneme vedení V1B a doplníme odpory na vedení V1A. Uzel 3 zadáme jako referenční. V tabulce uzlů doplníme odběry výkonu, zadané napětí a regulační rozsah jalového výkonu v uzlu 3 (absU = $110 \mathrm{kV}$ a Qmax = 100 Mvar). Pak chod sítě uložíme pod novým jménem (např. 2G-4B). Dodávku výkonů generátorů G1 a G2 postupně doladíme (změnou v tabulce uzlů, uložením bez vzniku nové varianty a přepočítáním chodu) tak, aby vedením V1A tekl do uzlu 3 jen činný výkon 40 MW a dodávka výkonu do referenčního uzlu byla nulová.

Obsah vstupního souboru 2G-4B__ 0 .VET se záznamy větví je v tomto výpisu:

\begin{tabular}{|c|c|c|c|c|c|c|c|c|c|c|c|c|c|c|c|c|c|c|c|c|c|c|c|}
\hline \# & $\begin{array}{l}\text { Jmeno } \\
\text { vetve }\end{array}$ & $\begin{array}{r}\mathrm{Uz} \\
\mathrm{POC}\end{array}$ & $\begin{array}{l}\text { el } \\
\text { Kon }\end{array}$ & R & $\left.{ }_{(\Omega)}\right)^{\mathrm{X}}(\mu$ & $\begin{array}{l}\text { B } \\
\text { S) }\end{array}$ & $\begin{array}{l}\text { absp } \\
(-)\end{array}$ & $\begin{array}{l}\operatorname{argp} \\
\left({ }^{\circ}\right)\end{array}$ & $\begin{array}{l}\text { Stav } \\
(0 / 1)\end{array}$ & $\mathrm{G}_{\text {PoC }}$ & $\begin{array}{l}B_{\text {PoC }} \\
(\mu S)\end{array}$ & $\mathrm{G}_{\mathrm{Kon}}$ & B Kon & $\begin{array}{c}I / S_{\max } \\
(\mathrm{A} / \mathrm{MVA})\end{array}$ & $\mathbf{R}_{0}$ & $\mathrm{x}_{0}$ & $\begin{array}{l}B_{0} \mathbf{Z} \\
(\mu S)\end{array}$ & zap & $\mathrm{G}_{p 0}$ & & $\begin{array}{l}\mathrm{G}_{\mathrm{KO}} \\
\mathrm{S} \text { ) }\end{array}$ & $\begin{array}{r}\mathrm{B}_{\mathrm{K} 0} \\
\mathrm{~N}\end{array}$ & $\begin{array}{l}\text { HO } \\
\text { hod) } \\
\text { vetx }\end{array}$ \\
\hline 1 & ' $\mathrm{T} \overline{1 '}$ & $\overline{1}$ & 2 & $\overline{0}$ & $\overline{24.4}$ & 0 & $0.90 \overline{9}$ & 0 & 1 & $\overline{0}$ & 0 & $\overline{0}$ & 0 & 63 & 0 & $2 \longdiv { 4 . 4 }$ & 0 & $\overline{-4}$ & 0 & $\overline{0}$ & $\overline{0}$ & 0 & 1 \\
\hline 2 & 'V1A' & 3 & 2 & 32 & 280 & 0 & 1.000 & 0 & 1 & 0 & 0 & 0 & 0 & 500 & 64 & 400 & 0 & 1 & 0 & 0 & 0 & 0 & 0 \\
\hline 3 & 'V1B' & 3 & 2 & 0 & 80 & 0 & 1.000 & 0 & 0 & 0 & 0 & 0 & 0 & 500 & 0 & 400 & 0 & 1 & 0 & 0 & 0 & 0 & 0 \\
\hline 4 & 'T2' & 4 & 3 & 0 & 25.41 & 0 & 1.000 & 0 & 1 & 0 & 0 & 0 & 0 & 50 & 0 & 25.41 & 110 & -4 & 0 & 0 & 0 & 0 & 1 \\
\hline
\end{tabular}

Změněné položky jsou zvýrazněny tučně.

Po vyladění chodu sítě bude obsah vstupního souboru 2G-4B000.UST takový:

\begin{tabular}{|c|c|c|c|c|c|c|c|c|c|c|c|c|}
\hline $\begin{array}{l}\text { Uziv. } \\
\text { Číslo }\end{array}$ & $\begin{array}{r}\text { Jmeno } \\
\text { uzlu }\end{array}$ & $\begin{array}{l}\text { C. } \\
\text { obl }\end{array}$ & $\begin{array}{c}\mathrm{UV} \\
.[\mathrm{kV}]\end{array}$ & $\begin{array}{c}\mathrm{absU} \\
{[\mathrm{kV}]}\end{array}$ & $\begin{array}{c}\text { argu } \\
\text { [stup] }\end{array}$ & $\begin{array}{l}\mathrm{Podb} \\
{[\mathrm{MW}]}\end{array}$ & $\begin{array}{l}\text { Qodb } \\
{[\text { MVAr] }}\end{array}$ & $\begin{array}{l}\text { Pdod } \\
{[\mathrm{MW}]}\end{array}$ & $\begin{array}{l}\text { Qdod } \\
\text { [MVAr] }\end{array}$ & Qkomp & $\begin{array}{l}\text { Qmin } \\
\text { [MVAr }\end{array}$ & $\begin{array}{lll}\text { Omax } & \text { Uzad } & \mathrm{Nk} \\
& {[\mathrm{kV}]} & {[-]}\end{array}$ \\
\hline 1 & Y & 1 & 10.5 & 1175 & 17.74 & 0.0 & 0.0 & 493 & 198 & $0 \Omega$ & 0 & 0 \\
\hline 2 & IUZFT DS1 & 11 & 110 & 1251 & 1345 & 50 & 50 & 0 & 0 & 0 & 0 & -110 \\
\hline 3 & 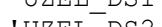 & 1 & $1 \pm 0$ & $125 \cdot 1$ & $\perp 3 \cdot 40$ & 3.0 & 3.0 & 0 & 0 & .0 & .0 & $123 \cdot 110$ \\
\hline 3 & 'UZEL_DS2 & 1 & 110 & 110.0 & 0.00 & 0.0 & 0.0 & 0.0 & 0.0 & 0.0 & 0.0 & 100110.000 \\
\hline 4 & 'UZEL_US & 1 & 30 & 30.10 & -4.81 & 140 & 87 & 99.9 & 90.3 & 0.0 & 0.0 & 0.030 .0830 \\
\hline
\end{tabular}

Upravené položky jsou opět zvýrazněny tučně.

Nakonec zbývá vyměnit tvrdý zdroj za generátor G2. Snadno se to provede v textovém režimu př́mo ve vstupním souboru $2 \mathrm{G}-4 \mathrm{~B} 1$ __. GEN podle tohoto výpisu:

\begin{tabular}{|c|c|c|c|c|c|c|c|c|c|c|}
\hline $\begin{array}{l}\text { Porad } \\
\text { cislo }\end{array}$ & $\begin{array}{l}\text { Stav } \\
(01)\end{array}$ & $\begin{array}{l}\text { Jmeno } \\
\text { Bloku }\end{array}$ & $\begin{array}{l}\text { Jmeno } \\
\text { Uzlu }\end{array}$ & $\begin{array}{l}\mathrm{Sn} \\
(\mathrm{MVA})\end{array}$ & $\begin{array}{l}\text { Ntmin } \\
\text { (MW) }\end{array}$ & $\begin{array}{l}\text { Ntmax } \\
(\mathrm{MW})\end{array}$ & $\begin{array}{c}\mathrm{Xd} \\
(-)\end{array}$ & $\begin{array}{l}\text { Pt } \\
(-)\end{array}$ & $\begin{array}{l}\mathrm{Xt} \\
(-)\end{array}$ & $\begin{array}{l}\text { Part } \text { PRR } \\
(-) \quad(\mathrm{MW})\end{array}$ \\
\hline 1 & 1 & ' $\overline{\mathrm{G} 1}$ ' & 'S $\overline{\text { VORKY }} \overline{\text { ' }}$ & $62 . \overline{5}$ & 0.0 & 60 & $0 . \overline{000}$ & 1 & $0.0 \overline{00}$ & 0.000 \\
\hline 2 & 1 & 'G2' & 'UZEL_US' & 150.0 & 0.0 & 140 & 0.000 & 1 & 0.075 & 0.000 \\
\hline
\end{tabular}


Novému generátoru je třeba přiřadit také dynamický model. To se provede pomocí Editoru dynamických modelů, kdy se napřed bloku G2 přidá záznam, změní model generátoru na PARK, přiřadí sada typových parametrů P50PAR a úpravy se uloží jako nová modifikace.

Zbývá jen opravit scénář. Změníme místo zkratu na konec vedení V1A a parametr zásahu CLER změníme na 3 (vypne se jen zkrat a ne samotné vedení V1A).

Nyní již můžeme spustit simulaci a najít postupně (zkracováním doby trvání zkratu) CCT. Následující obrázek ukazuje průběhy činných výkonů a zátěžných úhlů obou generátorů pro $\mathrm{CCT}=0.8375 \mathrm{~s}$.
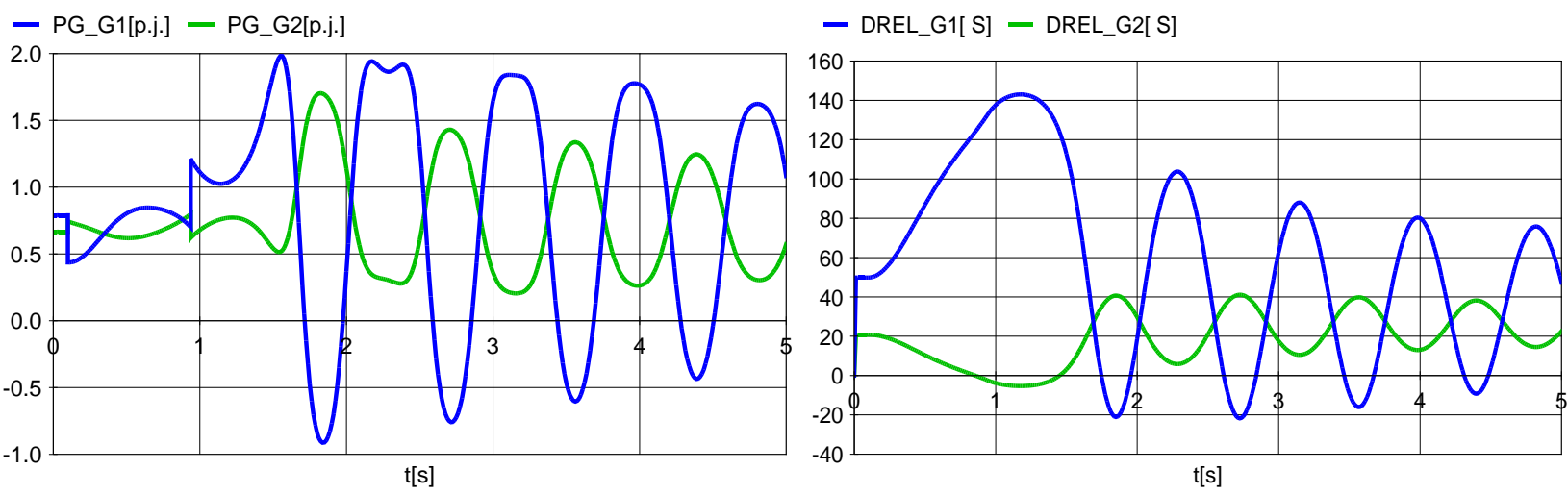

Obr. 3.2-19 Trajektorie kyvů výkonu pro jednofázový zkrat s úspěšným opětným zapnutím

Místo úhlu $\vartheta$ rozhoduje u dvoustrojové soustavy vzájemný úhel, jako rozdíl obou úhlů zobrazených v pravé části obrázku. Z něho se dá odečíst pro okamžik vypnutí hodnota $133^{\circ}$, což dobře odpovídá limitnímu úhlu spočtenému ve skriptu $\left(131^{\circ}\right)$. CCT ze simulačního výpočtu vychází o něco delší $(0.7 \mathrm{~s})$ než ve skriptu, což souvisí s tím, že byly použity větší mechanické časové konstanty oproti skriptu (6 a $10 \mathrm{~s})$.

Z časových průběhů je vidět, že generátory kývou proti sobě a kývání se postupně tlumí působením buzení a přechodných dějů v rotorových obvodech.

\subsection{Kontrolní otázky}

1. Jak se přejde od jednopólového k náhradnímu schématu?

2. Čím je dán činný výkon synchronního generátoru přenášený do tvrdé sítě?

3. Co je to klasický model generátoru?

4. Co je to fázorový diagram?

5. Co je to Parkův model generátoru?

6. Co je to buzení synchronního stroje?

7. Co ovlivňuje frekvenci kývání synchronního generátoru?

8. Jak se spočítá mezní doba trvání zkratu?

9. Který z typů zkratů ohrožuje úhlovou stabilitu nejvíce a který nejméně?

10. Co podstatně ovlivňuje velikost proudů při nesymetrických zkratech? 


\section{Frekvenční stabilita}

Frekvenční stabilita souvisí se schopností elektrizační soustavy udržet rovnováhu mezi činnými výkony zdrojů (obvykle turbín) a spotřebičů. K této nerovnováze dojde např. při změně dodávaného výkonu (např. výpadkem zdroje) nebo při změně odebíraného výkonu (např. připnutím nového zatížení). Ukážeme si tedy nejprve, jak se tato porucha projeví na ostatních generátorech v propojené ES. Jedná se o tzv. ráz činného výkonu.

\subsection{Ráz činného výkonu}

Předpokládejme, že v soustavě dojde k náhlému výpadku výkonu $\Delta \mathrm{P}$ (napřr. vypnutím elektrárenského bloku ochranou). Jelikož v každém okamžiku musí v soustavě prakticky platit rovnováha elektrických výkonů (tj. výkon zdrojů pokrývá odběry zatížení a ztráty v sítích), převezmou výkon $\Delta \mathrm{P}$ ostatní zdroje. $\mathrm{V}$ prvním okamžiku se tento děj nazývá ráz činného výkonu. Dá se dokázat (odvození je v knize [4][30] na str. 96), že př́i tomto elektrickém rozdělení se výpadek výkonu i-tého generátoru $\Delta \mathrm{P}^{\mathrm{i}}$ rozdělí mezi zbývajících $\mathrm{N}$ synchronních generátorů v poměru elektrických vzdáleností od místa výpadku. To lze vyjádřit matematicky rovnicemi:

$$
\Delta \mathrm{P}_{K}^{i}=\Delta \mathrm{P}^{i} \frac{K_{E k}^{i}}{\sum_{j=1}^{N} K_{E j}^{i}}, \quad K_{E k}^{i}=\frac{\mathrm{X}_{\mathrm{ik}}}{\mathrm{X}_{\mathrm{Gk}}},
$$

kde $\Delta \mathrm{P}_{K}^{i}$ je ráz výkonu na k-tý generátoru při výpadku i-tého generátoru, $\mathrm{X}_{\mathrm{ik}}$ je náhradní reaktance mezi uzly i a k (prvek zkratové impedanční matice se zanedbáním činných odporů) a $\mathrm{X}_{\mathrm{Gk}} \mathrm{je}$ náhradní reaktance synchronního generátoru (včetně blokového transformátoru).

\section{Př́klad 4-1}

V soustavě z Obr. 4.1-1 došlo k výpadku generátoru GEN2. Zjistěte rázy činného výkonu na zbylé generátory GEN1 a GEN3 pro okamžik výpadku.

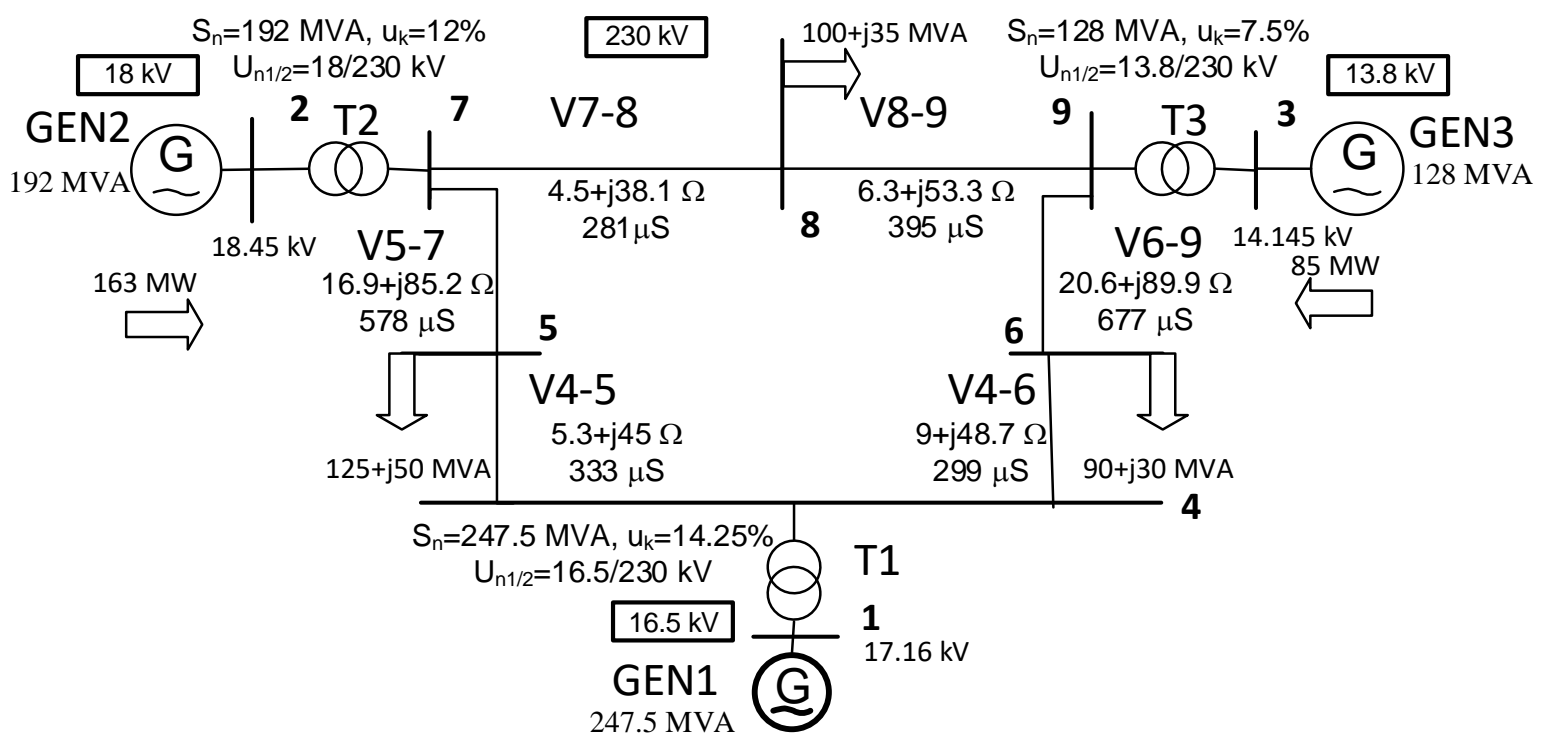

Obr. 4.1-1 Model devítiuzlové soustavy

Model odpovídá testovací soustavě WSCC (,Western System Coordinating Council“), někdy označované i jako „IEEE 9-bus“ (podrobněji viz [31]). 


\section{Řešení}

Pro určení rázů činného výkonu na generátory použijeme nejprve vztahy (4.1-1). Pro výpočet koeficientů $K_{\mathrm{E}}$ (bezrozměrné hodnoty s významem elektrické vzdálenosti zdroje od místa poruchy) je potřeba náhradní reaktance $\mathrm{X}_{21}$ a $\mathrm{X}_{23}$. Pro jejich zjištění zjednodušíme model vypuštěním zátěží, zanedbáním odporů a susceptancí a sloučením vedení v sérii, takže náhradní schéma soustavy se zjednoduší na trojuzlové podle Obr. 4.1-2:

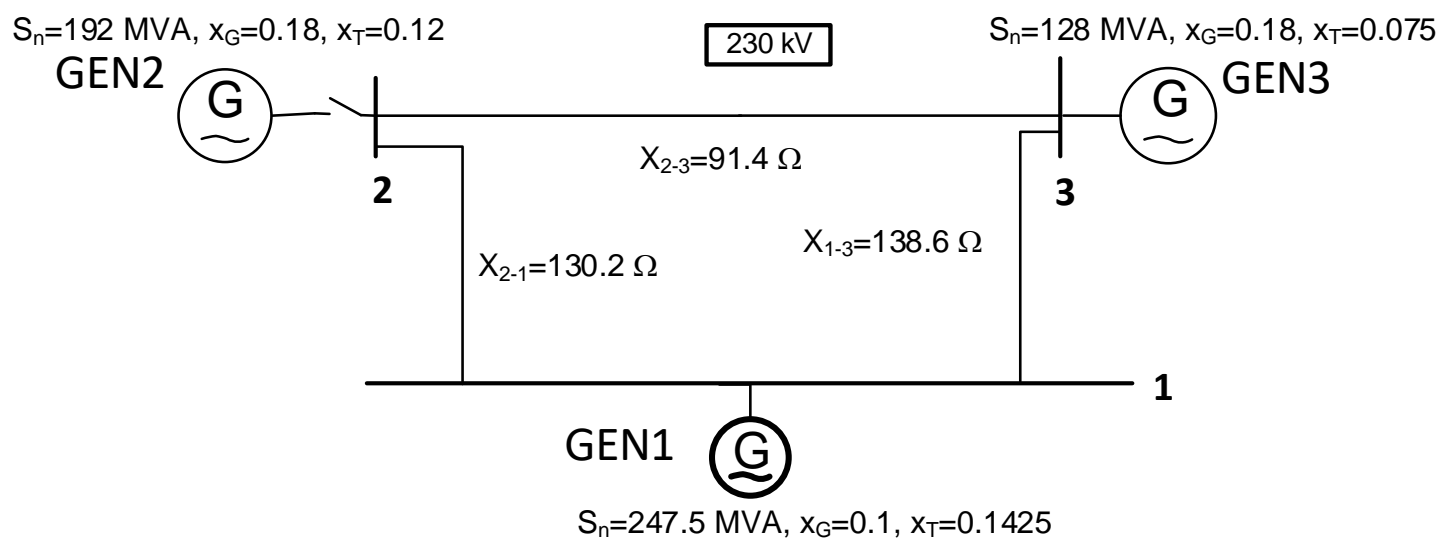

\section{Obr. 4.1-2 Náhradní schéma pro výpočet elektrické vzdálenosti}

Reaktance snadno spočteme: $\mathrm{X}_{21}=\mathrm{X}_{2-1} \|\left(\mathrm{X}_{2-3}+\mathrm{X}_{1-3}\right)=83$ a $\mathrm{X}_{23}=\mathrm{X}_{2-3} \|\left(\mathrm{X}_{2-1}+\mathrm{X}_{1-3}\right)=67.5 \Omega$.

Pro výpočet reaktancí generátorů $\mathrm{X}_{\mathrm{Gk}}$ sloučíme reaktanci generátoru (pro rázový jev použijeme rázové reaktance $x_{d}$ ") a blokového trafa a přepočteme na pojmenované hodnoty: $\mathrm{X}_{\mathrm{G} 1}=$ $\left(x_{\mathrm{G} 1}+x_{\mathrm{T} 1}\right) \cdot 230^{2} / \mathrm{S}_{\mathrm{n} 1}=51.8 \Omega, \mathrm{X}_{\mathrm{G} 2}=\left(x_{\mathrm{G} 2}+x_{\mathrm{T} 2}\right) \cdot 230^{2} / \mathrm{S}_{\mathrm{n} 2}=105.4 \Omega$.

Jednotlivé koeficienty pak vycházejí (pro zjednodušení zápisu jsou dále vynechány horní indexy): $K_{\mathrm{E} 1}=83 / 51.8=1.6$ a $K_{\mathrm{E} 3}=67.5 / 105.4=0.64$

Elektrické rozdělení rázu činného výkonu bude $\Delta \mathrm{P}_{1}=\Delta \mathrm{P} \cdot K_{\mathrm{E} 1} /\left(K_{\mathrm{E} 1}+K_{\mathrm{E} 3}\right)=116.4 \mathrm{MW}$ a $\Delta \mathrm{P}_{3}=\Delta \mathrm{P} \cdot K_{\mathrm{E} 3} /\left(K_{\mathrm{E} 1}+K_{\mathrm{E} 3}\right)=46.6 \mathrm{MW}$.

Nyní můžeme ráz činného výkonu ověrit i na dynamickém modelu. Výchozí chod sítě WSCC9000 je připraven v projektu FRK_STAB, který otevřeme (1.). V projektu je prripraven prrípad UST_WSCC $\mathrm{s}$ tímto chodem. Ve výchozím př́padu jsou již nadefinovány $\mathrm{v}$ databázi dynamických modelů bloku klasické modely generátoru (CLAS) s typovými parametry podle následující tabulky:

Tab. 4.1-1 Typové parametry generátoru (přepočítáno z tab. 2.1 v knize [32])

\begin{tabular}{|c|c|c|c|c|c|c|c|c|c|c|c|c|c|c|c|}
\hline Generátory & \begin{tabular}{|l}
$\begin{array}{l}\mathrm{U}_{\mathrm{n}} \\
(\mathrm{kV})\end{array}$ \\
\end{tabular} & \begin{tabular}{|l}
$\begin{array}{l}\operatorname{Cos}_{n} \\
(-)\end{array}$ \\
\end{tabular} & $\begin{array}{l}\begin{array}{l}\text { Sng } \\
\text { (MVA) }\end{array} \\
\end{array}$ & \begin{tabular}{|l}
$X_{d}$ \\
$(-)$
\end{tabular} & \begin{tabular}{|l}
$X_{q}$ \\
$(-)$
\end{tabular} & \begin{tabular}{|l}
$X_{d}^{\prime}$ \\
$(-)$
\end{tabular} & \begin{tabular}{|l}
$X_{d}^{\prime \prime}$ \\
$(-)$ \\
\end{tabular} & \begin{tabular}{|l|}
$X_{\mathrm{t}}$ \\
$(-)$ \\
\end{tabular} & \begin{tabular}{|l} 
Tad \\
$(\mathrm{S})$ \\
\end{tabular} & \begin{tabular}{|l}
$T_{d 0} "$ \\
$(S)$ \\
\end{tabular} & \begin{tabular}{|c|}
$T_{q 0}{ }^{\prime \prime}$ \\
$(\mathrm{s})$ \\
\end{tabular} & \begin{tabular}{|l}
$\mathrm{T}_{\mathrm{m}}$ \\
$(\mathrm{s})$
\end{tabular} & \begin{tabular}{|l}
$\mathrm{X}_{q^{\prime}}$ \\
$(-)$ \\
\end{tabular} & \begin{tabular}{|l}
$\mathrm{Tq0}^{\prime}$ \\
$(\mathrm{s})$ \\
\end{tabular} & $\begin{array}{l}\text { Komentář } \\
\text { (text) }\end{array}$ \\
\hline G1P & 16.5 & 0.85 & 247 & 0.361 & 0.239 & 0.15 & 0.1 & 0 & 8.96 & 0.06 & 0.4 & 19.14 & 0.239 & 0.6 & Hydro dle A\&F \\
\hline G2P & 18 & 0.85 & 192 & 1.72 & 1.66 & 0.23 & 0.18 & 0 & 6 & 0.06 & 0.4 & 6.66 & 0.3 & 0.535 & Turbo dle $A \& F$ \\
\hline G3P & 13.8 & 0.85 & 128 & 1.68 & 1.61 & 0.232 & 0.18 & 0 & 5.89 & 0.06 & 0.4 & 4.7 & 0.32 & 0.6 & Turbo dle A\&F \\
\hline
\end{tabular}

Doba výpočtu se zadá $2 \mathrm{~s}$, spolu s krokem výpisu $0.025 \mathrm{~s}$ (…). Do scénáře (‥) se definuje $\mathrm{v}$ čase $\mathrm{t}=1 \mathrm{~s}$ vypnutí generátoru G2 zásahem UNIT s parametrem. Do grafiky (ㄸ.) se zadají proměnné $\mathrm{PG}$ pro všechny tři generátory. 
Po spuštění programu MODES (1.2) jsou na grafu vidět průběhy s rázy činného výkonu na oba generátory podle Obr. 4.1-3:

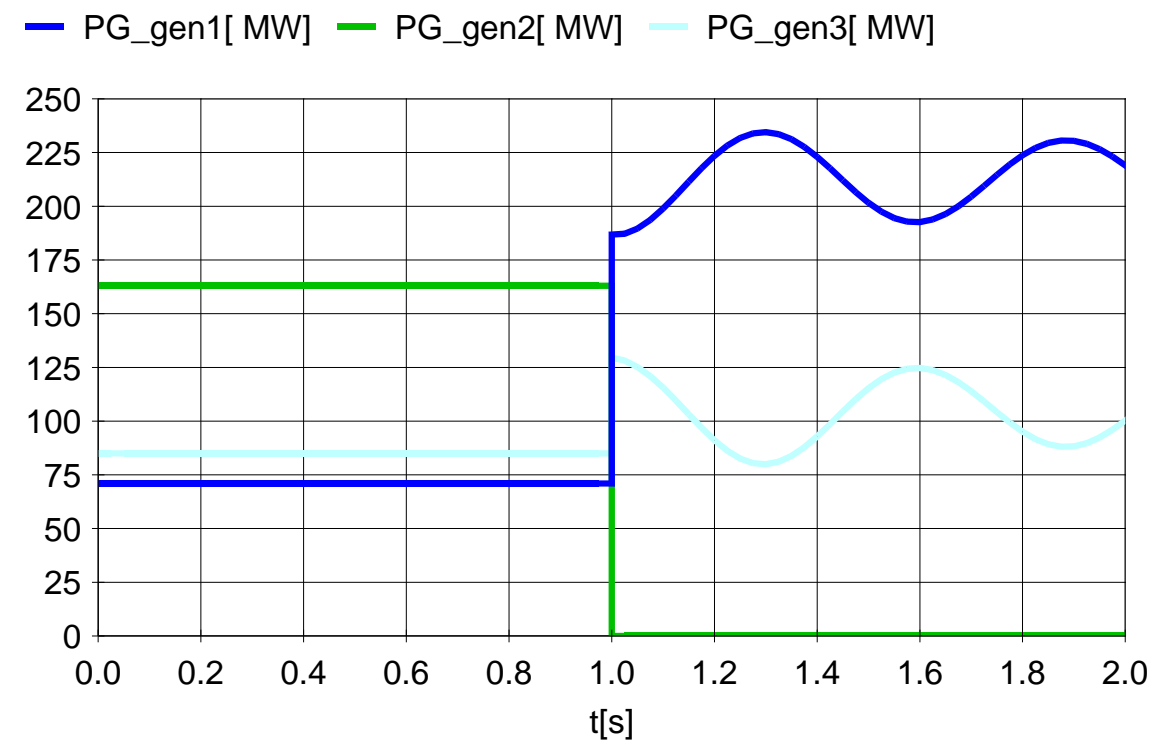

Obr. 4.1-3 Průběhy výkonů generátoru po výpadku generátoru GEN2

$\mathrm{V}$ čase $\mathrm{t}=1 \mathrm{~s}$ jsou vidět skokové změny výkonů generátorů, které odpovídají staticky spočtenému elektrickému rozdělení rázu činného výkonu $\Delta \mathrm{P}_{1} \mathrm{a} \Delta \mathrm{P}_{3}$. 


\subsection{Primární regulace frekvence}

Dosud jsme předpokládali, že během přechodných dějů se frekvence napětí nemění, a tudíž mechanický výkon turbíny se považoval za konstantní. V dalším výkladu tento předpoklad opustíme a změnu výkonu turbíny, jako odezvu na změnu frekvence, budeme uvažovat. Jedná se o primární regulaci frekvence, kterou podrobně vysvětlíme v dalším výkladu.

Na elektrické rozdělení rázu činného výkonu navazuje elektromechanický přechodný jev popsaný pohybovými rovnicemi jednotlivých soustrojí: $\Delta \mathrm{P}_{\mathrm{k}}$ vstupuje jako změnová veličina na pravou stranu pohybové rovnice (3.2-1) a určuje změnu otáček jednotlivých turbín a tím i celkovou změnu frekvence $\Delta \mathrm{f} v$ propojené ES. Předpokládejme, že na odchylku frekvence $\Delta \mathrm{f}$ reagují turbíny zařazené $\mathrm{v}$ primární regulaci frekvence odchylkou výkonu $-K_{\mathrm{P}} \Delta \mathrm{f}$ od výchozí hodnoty $\mathrm{P}_{0}$. Neboli $\mathrm{P}_{\mathrm{M}}=\mathrm{P}_{0}-\mathrm{K}_{\mathrm{P}} \Delta \mathrm{f}$, kde $\mathrm{K}_{\mathrm{P}}$ je zesílení primární regulace $\mathrm{v} \mathrm{MW} / \mathrm{Hz}$ (používá se rovněž termín statika $\sigma$ jako procentní inverzí hodnota $\mathrm{k}$ zesílení).

Pro stacionární stav (po odeznění primárního regulačního děje a elektromechanických kyvů) je derivace na levé straně nulová, takže rovnice pro k-tý blok přejde do tvaru:

$$
\Delta \mathrm{P}_{\mathrm{k}}=-\mathrm{K}_{\mathrm{Pk}} \Delta \mathrm{f} \text {. }
$$

Jestliže sečteme př́spěvky generátorů $\Delta \mathrm{P}_{\mathrm{k}} \mathrm{V}$ soustavě, musí se tento součet (při zanedbání regulačního efektu zátěže a změn ztrát $\mathrm{v}$ sítích) rovnat celkovému výpadku $\Delta \mathrm{P}$.

Za předpokladu stejné odchylky frekvence ve všech uzlech pak můžeme napsat rovnici pro primárními regulátory ř́zené rozdělení rázu činného výkonu $\Delta \mathrm{P}$ mezi $\mathrm{N}$ bloků:

$\Delta \mathrm{P}_{k}=\Delta \mathrm{P} \frac{\mathrm{K}_{\mathrm{Pk}}}{\sum_{j=1}^{N} \mathrm{~K}_{\mathrm{Pj}}} \quad[\mathrm{MW}, \mathrm{MW} / \mathrm{Hz}], \quad \mathrm{K}_{\mathrm{P}}=\mathrm{P}_{\mathrm{Mn}} \frac{100}{\mathrm{f}_{\mathrm{n}} \sigma} \quad[\mathrm{MW} / \mathrm{Hz}, \mathrm{MW}, \mathrm{Hz}, \%]$,

kde $\mathrm{P}_{\mathrm{Mn}}$ je jmenovitý výkon turbíny, $\mathrm{f}_{\mathrm{n}}$ jmenovitá frekvence sítě a $\sigma$ je statika primární regulace.

Po ustálení regulačního děje si tedy bloky (tím se rozumí soustrojí generátor - turbína budič) přerozdělí výkonový deficit $\Delta \mathrm{P}$ v poměru svých výkonových čísel $\mathrm{K}_{\mathrm{P}}$. Tato rovnice vyjadřuje tzv. primárními regulátory rozdělení rázu činného výkonu.

\section{Př́klad 4-2}

V soustavě z Obr. 4.1-1 došlo k výpadku generátoru GEN2. Zjistěte primárními regulátory rozdělení rázu činného výkonu na zbylé generátory GEN1 a GEN3. Jmenovité výkony turbín se rovnají jmenovitému činnému výkonu generátoru $\mathrm{P}_{\mathrm{Gn}}=\mathrm{S}_{\mathrm{n}} \cos \varphi_{\mathrm{n}}$. Statiky regulátoru budou $\sigma_{1}=5 \%$ a $\sigma_{2}=10 \%$.

\section{Řešení}

Pro určení přerozdělení rázu činného výkonu na bloky použijeme nejprve vztahy (4.2-1). Výkonová čísla $K_{P}$ jednoduše spočteme ze zadaných hodnot $\left(S_{n}\right.$ a $\cos \varphi_{n}$ jsou $v$ Tab. 4.1-1): $\mathrm{K}_{\mathrm{P} 1}=247 \cdot 0.85 \cdot 100 / 5 / 50=84.15 \mathrm{MW} / \mathrm{Hz}$ a $\mathrm{K}_{\mathrm{P} 3}=128 \cdot 0.85 \cdot 100 / 10 / 50=21.76 \mathrm{MW} / \mathrm{Hz} . \mathrm{Z}$ nich se zjistí přerozdělení rázu činného výkonu: $\Delta \mathrm{P}_{1}=\Delta \mathrm{P} \cdot \mathrm{K}_{\mathrm{P} 1} /\left(\mathrm{K}_{\mathrm{P} 1}+\mathrm{K}_{\mathrm{P} 3}\right)=129.5 \mathrm{MW}$ a $\Delta \mathrm{P}_{3}=\Delta \mathrm{P} \cdot \mathrm{K}_{\mathrm{P} 3} /\left(\mathrm{K}_{\mathrm{P} 1}+\mathrm{K}_{\mathrm{P} 3}\right)=33.5 \mathrm{MW}$.

Tomu odpovídají výkony po přerozdělení $\mathrm{P}_{1}=200.5 \mathrm{MW}$ a $\mathrm{P}_{3}=118.5 \mathrm{MW}$.

Nyní můžeme nasimulovat primárními regulátory turbín přerozdělení rázu činného výkonu i na dynamickém modelu. Použijme předchozí výpočtový př́ípad, který má již nadefinovány v databázi dynamických modelů bloku standardní modely parní turbíny (STAN). Blokové schéma je znázorněno na Obr. 4.2-1. 


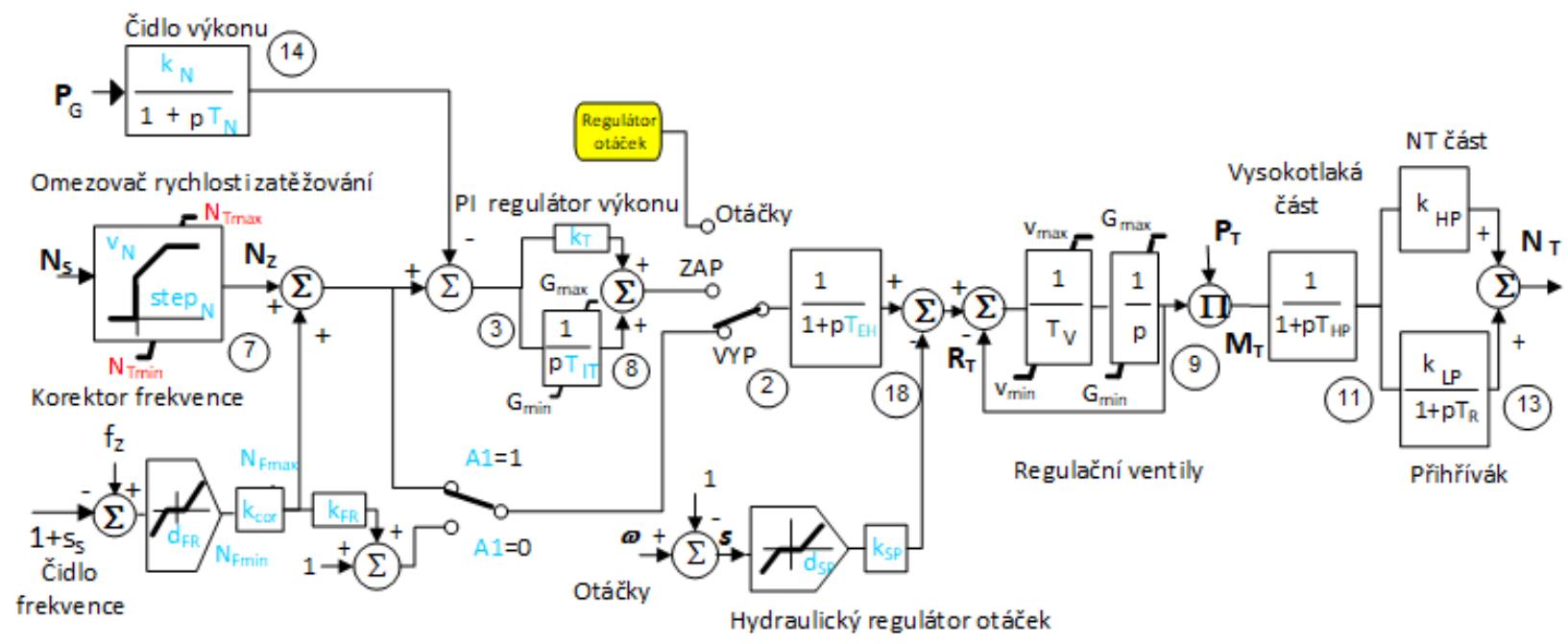

Obr. 4.2-1 Blokové schéma modelu turbíny STAN

Model má již vyřazen regulátor výkonu (přepínač je v poloze VYP), takže výstup regulátoru turbíny $\mathrm{R}_{\mathrm{T}}$ je určen pouze (při konstantní hodnotě požadovaného výkonu NS a nulovém zesíleni korektoru frekvence $\mathrm{k}_{\mathrm{cor}}=0$ ) hydraulickým regulátorem otáček, jehož zesílení odpovídá $\mathrm{k}_{\mathrm{SP}}=100 / \sigma$.

Pro splnění zadání je potřeba v Editoru dynamických modelů bloku vybrat vhodnou sadu parametrů z katalogu typových parametrů. Požadavky zadání splňují dvě sady z Tab. 4.2-1:

Tab. 4.2-1 Typové parametry regulátoru turbíny se statikou 5 a 10 \% a nulovým zesílením kcor

\begin{tabular}{|c|c|c|c|c|c|c|c|c|c|c|c|c|c|c|c|c|}
\hline Regulatory_T & A1 & A2 & $\begin{array}{l}\mathrm{T}_{\text {IT }} \\
\mathrm{S}\end{array}$ & $\begin{array}{l}\mathrm{T}_{\mathrm{N}} \\
\mathrm{S}\end{array}$ & $\begin{array}{l}\mathrm{T}_{\mathrm{EH}} \\
\mathrm{S}\end{array}$ & $\mathrm{kT}$ & $\mathbf{k}_{\mathrm{sp}}$ & $\mathrm{k}_{\mathrm{Fr}}$ & $\mathrm{K}_{\mathrm{COR}}$ & $\begin{array}{l}\mathrm{v}_{\mathrm{N}} \\
\frac{\circ}{\circ} / \mathrm{min}\end{array}$ & $\begin{array}{l}\text { step } \\
\frac{0}{0}\end{array}$ & $\begin{array}{l}d_{F r} \\
\frac{\circ}{0}\end{array}$ & $\begin{array}{l}d_{S p} \\
\frac{\circ}{0}\end{array}$ & $\begin{array}{l}\mathrm{N}_{\text {Fmax }} \\
\frac{0}{0}\end{array}$ & $\begin{array}{l}\mathrm{N}_{\text {Fmin }} \\
\frac{0}{0}\end{array}$ & Koment (text) \\
\hline SCOC_5 & 1 & 0 & 10 & 1 & 10 & 1 & 20 & 0 & 0 & 50 & 50 & 0 & 0 & 0 & 0 & statika regulátoru otáček 5\% \\
\hline SCoc10 & 1 & 0 & 10 & 1 & 0.1 & 1 & 10 & 0 & Ju & 50 & 50 & 0 & 0 & 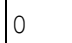 & 0 & statika regulátoru otáček 10\% \\
\hline
\end{tabular}

Bloku GEN1 se přiřadí typové parametry SCoC_5 a bloku GEN3 parametry SCoC10.

Doba výpočtu se zadá $40 \mathrm{~s}$ ( $\mathrm{s}$ krokem výpisu $0.1 \mathrm{~s}$ ), do scénáře se definuje v čase $\mathrm{t}=1 \mathrm{~s}$ vypnutí generátoru GEN2 zásahem UNIT s parametrem 0. Do grafiky se do 2. a 3. grafu zadají proměnné PG, NT (výkon turbíny) v pojmenovaných pro bloky GEN1 a GEN3.

Obr. 4.2-2 ukazuje průběhy přechodného děje po elektrickém rázu výkonu.
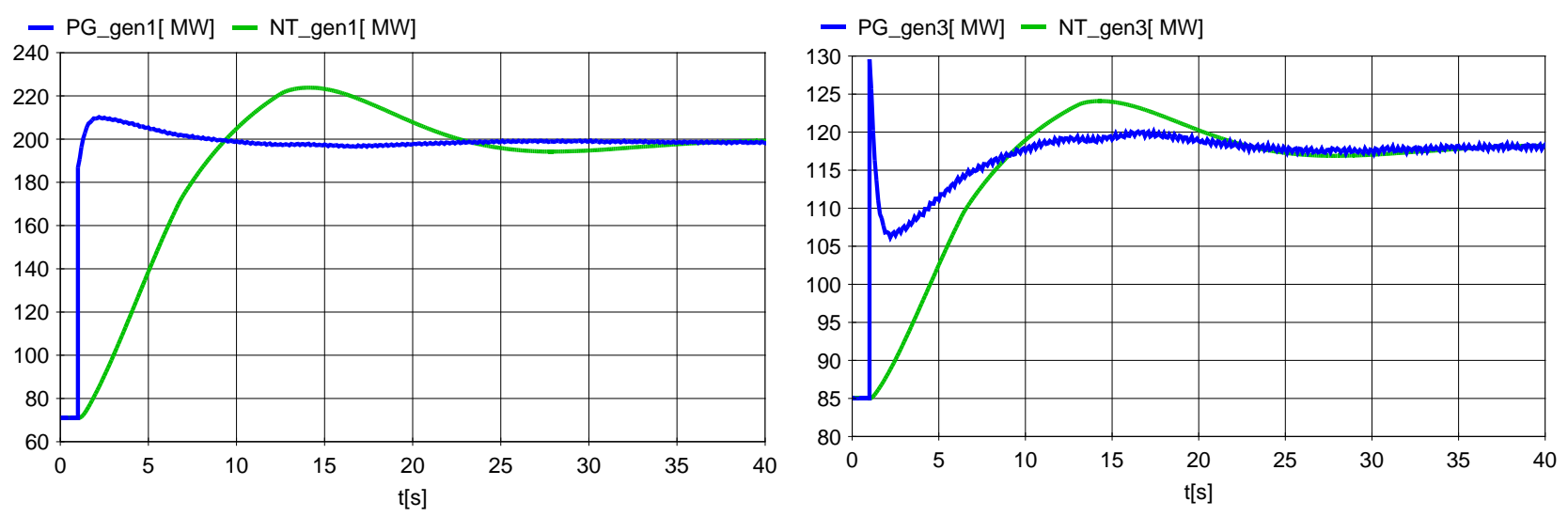

Obr. 4.2-2 Průběhy výkonů generátoru a turbíny během vyrovnávacích dějů po výpadku bloku GEN2

Ustálené hodnoty výkonů odpovídají dobře již spočteným hodnotám $200.5 \mathrm{MW}$ a 118.5 MW. Mezi elektrickým rázem a ustálenou hodnotou probíhá elektromechanický přechodný děj, kdy výkonová nerovnováha je hrazena z energie naakumulované v roztočených setrvačných hmotách. Výkon výpadku přebírá hlavně blok GEN1, který má větší výkon, ale 
hlavně mnohem větší mechanickou časovou konstantu $T_{M}$ (a tím i setrvačnost - podrobněji viz článek [33]) než GEN3, který po elektrickém rázu výkonu odlehčuje.

Druhý probíhající děj je regulační, kdy výkon obou turbín reaguje na odchylku frekvence a zvyšuje se podle dynamiky parní turbíny. Na regulačním ději je vidět i přeregulování způsobené zpožděním páry především ve vysokotlaké části turbíny a přehříváku. Následující tabulka ukazuje přehled parametrů parní turbíny.

Tab. 4.2-2 Typové parametry parní turbíny

\begin{tabular}{|c|c|c|c|c|c|c|c|c|c|c|c|}
\hline urbiny & $\begin{array}{l}\mathrm{k}_{\mathrm{N}} \\
- \\
\end{array}$ & $\begin{array}{l}\mathrm{T}_{\mathrm{V}} \\
\mathrm{S}\end{array}$ & \begin{tabular}{|l}
$\mathrm{T}_{\mathrm{HP}}$ \\
$\mathrm{S}$
\end{tabular} & \begin{tabular}{|l|}
$T_{R}$ \\
$S$ \\
\end{tabular} & $\begin{array}{l}\min \\
-/ s \\
\end{array}$ & $\left|\begin{array}{l}V_{\max } \\
-/ \mathrm{s}\end{array}\right|$ & $\begin{array}{l}\mathrm{G}_{\min } \\
- \\
\end{array}$ & $\begin{array}{l}\max \\
-\end{array}$ & $\begin{array}{l}K_{\mathrm{LP}} \\
- \\
\end{array}$ & $\begin{array}{l}K_{\mathrm{HP}} \\
-\end{array}$ & $\begin{array}{l}\text { Koment } \\
\text { text }\end{array}$ \\
\hline$S T \_A$ & 1.176 & 0.15 & 0.1 & 6 & -2.5 & 0.5 & 10 & 1.2 & 0.75 & 0.25 & !parni turbina s přihří \\
\hline
\end{tabular}

Pro parní turbínu s těmito parametry se $25 \%$ výkonu vyrábí ve vysokotlaké části s malým zpožděním $T_{H P}$ a zbytek $75 \%$ výkonu ve středotlaké a nízkotlaké části s větším zpožděním $T_{R}$, což je dáno koeficienty $\mathrm{K}_{\mathrm{HP}} \mathrm{a} \mathrm{K}_{\mathrm{LP}}$.

Dosud jsme uvažovali, že výkonový deficit pokrývají jenom zdroje, ale ve skutečnosti k tomu přispívá i zatížení, přesněji motorická zátěž, která reaguje na odchylku frekvence změnou odběru činného výkonu - regulačním efektem zátěže.

\section{Př́ḱlad 4-3}

V soustavě z Obr. 4.2-3 došlo k výpadku generátoru G2 o výkonu $500 \mathrm{MW}$. Generátor G1 pokrývá $60 \%$ zatížení a zajištuje primární regulaci celé soustavy se statikou $\sigma=7 \%$ a výkonovou rezervou $15 \%$. Zbytek zatížení (35\%) pokrývá generátor G3, pracující na konstantní plný výkon (bez regulace). Uvažujte regulační efekt zátěže $K_{\mathrm{L}}=1$ (při poklesu frekvence o $1 \%$ klesne zatížení také o $1 \%$ ). Zjistěte ustálenou odchylku frekvence po výpadku a podíl zátěže a generátoru G1 na pokrytí výpadku $500 \mathrm{MW}$.

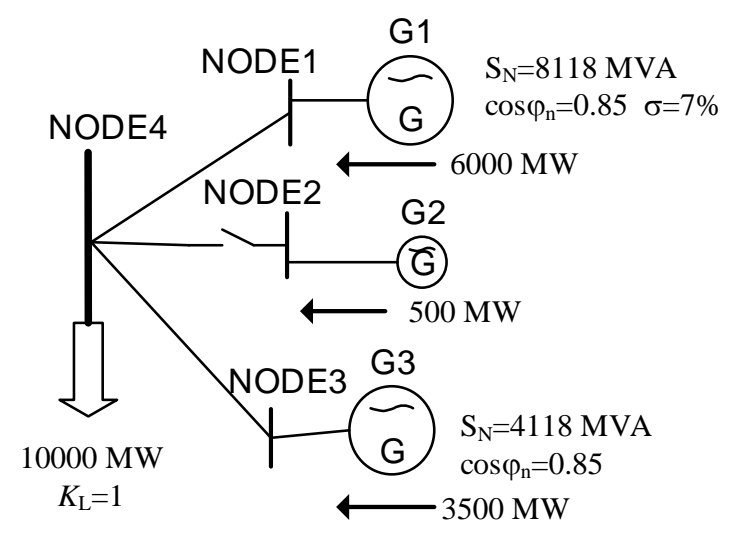

Obr. 4.2-3 Model jednouzlové soustavy

Př́klad byl převzat z knihy [34] („Example 9.1“ str. 358).

\section{Řešení}

Pro zjištění stacionární odchylky frekvence určíme napřed sumární výkonové číslo soustavy jako součet výkonového čísla zátěže a zdrojů (bloku G1). Výpočet provedeme $\mathrm{v}$ poměrných hodnotách vztažených na sumární výkon zátěže $\mathrm{P}_{\mathrm{L}}=10000 \mathrm{MW}$. Výkonové číslo zátěže $K_{\mathrm{L}}=$ máme přímo zadáno, takže zbývá dopočítat výkonové číslo zdroje dané regulací turbíny bloku G1. V poměrných hodnotách vychází $K_{\mathrm{T}}=100 \cdot \mathrm{Pn} / \mathrm{P}_{\mathrm{L}} / \sigma=9.857$. Odchylku frekvence zjistíme z celkového výkonového čísla $K_{\mathrm{S}}=K_{\mathrm{L}}+K_{\mathrm{T}}=10.857$ přepočtem na pojmenované jednotky $\Delta \mathrm{f}=-50 \Delta \mathrm{P} / K_{\mathrm{S}} / \mathrm{P}_{\mathrm{L}}=-0.2303 \mathrm{~Hz}$.

$\mathrm{Z}$ odchylky frekvence dopočítáme přerozdělení výpadku: $\Delta \mathrm{P}_{\mathrm{L}}=\mathrm{P}_{\mathrm{L}} \Delta \mathrm{f} \cdot K_{\mathrm{L}} / 50=-46 \mathrm{MW}$ a $\Delta \mathrm{P}_{\mathrm{T}}=-\mathrm{P}_{\mathrm{L}} \Delta \mathrm{f} \cdot K_{\mathrm{T}} / 50=454 \mathrm{MW}$. 
Nyní můžeme nasimulovat přerozdělení výpadku výkonu i na dynamickém modelu. Výchozí chod sítě odpovídající modelu jednouzlové soustavy je připraven v projektu FRK_STAB, takže se otevře př́pad UST1PCLI s tímto chodem.

Ve výchozím př́padu jsou již nadefinovány v databázi dynamických modelů bloku klasické modely generátoru (CLAS) s typovými parametry podle Tab. 4.1-1 a konstantní výkon turbíny (model CONS). Pro dynamický výpočet změníme modely a parametry bloku G1. Vyměníme původní typové parametry generátoru G1P za G3P (dostaneme tak realističtější chování modelované soustavy z hlediska setrvačnosti - původní mechanická časová konstanta $\mathrm{T}_{\mathrm{M}}$ byla nepřiměřeně velká). Dále vyměníme model turbíny CONS za STAN a přiřadíme parametry modelu turbíny ST_S z lokálního katalogu typových parametrů (viz Tab. 4.2-2) a regulátoru turbíny přiřadíme připravenou sadu $\mathrm{SCoC}_{-} 7 \mathrm{~s}$ parametry dle následující tabulky.

Tab. 4.2-3 Typové parametry regulátoru turbíny se statikou $7 \%$ a nulovým zesílením kcor

\begin{tabular}{|c|c|c|c|c|c|c|c|c|c|c|c|c|c|c|c|c|}
\hline Regulat & & & $\left|\begin{array}{l}T_{\text {IT }} \\
S\end{array}\right|$ & $\mid \begin{array}{l}T_{N} \\
S\end{array}$ & $\left|\begin{array}{l}T_{E H} \\
S\end{array}\right|$ & & $\mathbf{k}_{\mathrm{sp}}$ & $\mathrm{k}_{\mathrm{E}}$ & $\mathbf{K}_{\mathrm{co}}$ & $\begin{array}{l}V_{N} \\
\frac{O}{0} / \mathrm{min}\end{array}$ & & $d_{F r}$ & $\left|\begin{array}{l}d_{s p} \\
\frac{0}{0}\end{array}\right|$ & $\begin{array}{l}\mathrm{N}_{\mathrm{Fm}} \mathrm{x} \\
\frac{\mathrm{O}}{\mathrm{O}}\end{array}$ & & Koment (text) \\
\hline SCOC_7 & 1 & 0 & 10 & 1 & 10 & 1 & 14.3 & 0 & 0 & 50 & 50 & 0 & 0 & 0 & 0 & statika regulátoru otáček 7\% \\
\hline
\end{tabular}

V databázi dynamických modelů uzlů je již ve výchozím případu pro uzel NODE4 zadána statická zátěž s frekvenčním regulačním efektem 1.

Doba výpočtu se zadá $40 \mathrm{~s}$ ( $\mathrm{s}$ krokem výpisu $0.1 \mathrm{~s}$ ), do scénáře se definuje $\mathrm{v}$ čase $\mathrm{t}=1 \mathrm{~s}$ vypnutí generátoru G2 zásahem UNIT s parametrem 0 . Do grafiky se do 1 grafu zadá proměnná PO (odběr výkonu v uzlu) v pojmenovaných hodnotách v uzlu NODE 4, do 2. a 3. grafu se zadají proměnné PG, NT (výkon turbíny) v pojmenovaných hodnotách pro bloky G1 a G3 a do 4. grafu proměnná SU (odchylky frekvence) v pojmenovaných hodnotách v uzlu NODE1 .

Na Obr. 4.2-2 jsou výkony bloku a odchylka frekvence (odpovídá skluzu generátoru).

- PG_G1[MW] - NT_G1[MW]

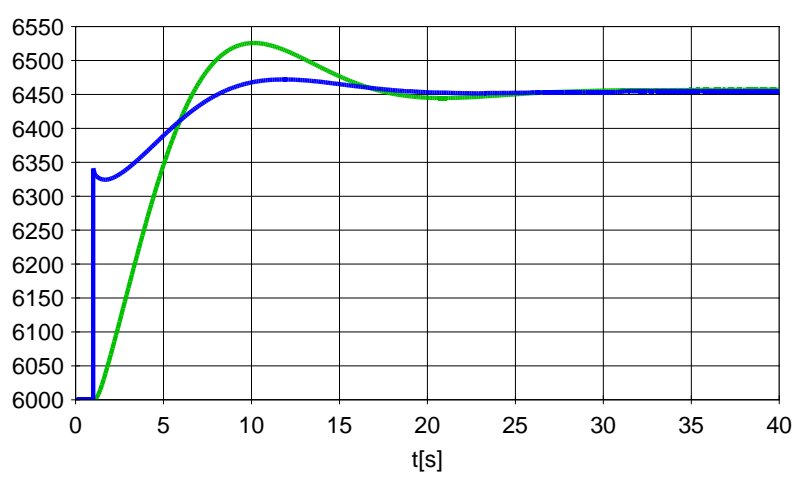

- SU_NODE1[ $\mathrm{mHz}]$

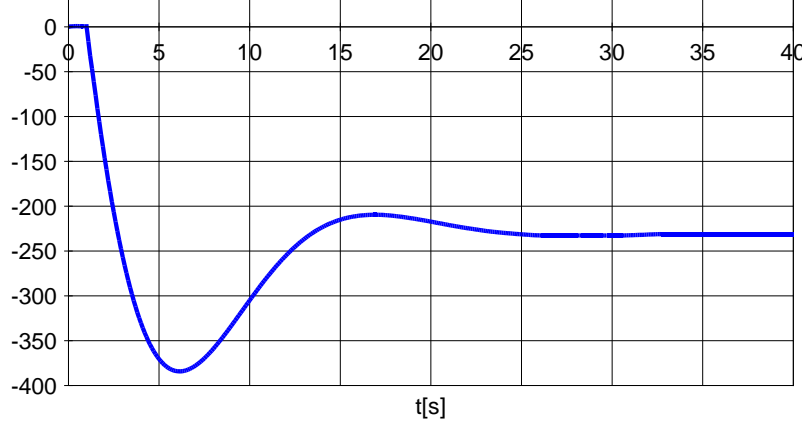

Obr. 4.2-4 Průběhy výkonů generátoru a turbíny a odchylky frekvence po výpadku bloku GEN2

V levém grafu je vidět př́růstek výkonu odpovídající staticky spočtené hodnotě $454 \mathrm{MW}$. Odchylka frekvence v pravém grafu rovněž odpovídá statickému výpočtu $\Delta \mathrm{f}=-0.23 \mathrm{~Hz}$.

Změna výkonu zátěže je vidět během simulačního výpočtu v 1 . grafu. Na konci simulace je odběr 99953.76 MW, což dobře odpovídá staticky spočtené hodnotě $\Delta \mathrm{P}_{\mathrm{L}}=-46 \mathrm{MW}$. 
Přibližné časové průběhy odchylky frekvence $\Delta \mathrm{f}$ po výpadku výkonu $\Delta \mathrm{P}$ lze získat analytickým řešením zjednodušeného lineárního modelu ES podle následujícího obrázku.

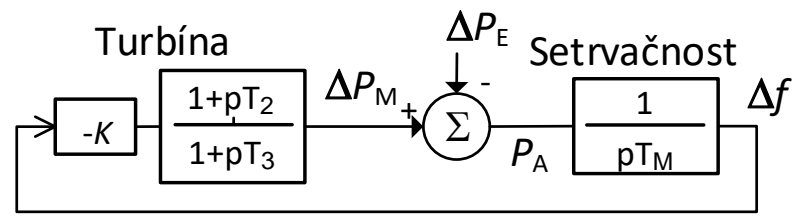

Obr. 4.2-5 Model ES pro odvození průběhu odchylky frekvence $\Delta f$ při výpadku výkonu $\Delta P_{E}$

Blokové schéma vzniklo odvozením z ekvivalentního modelu soustavy publikovaného v [35] (popis je také v knize [30] na str. 67). Zanedbal se regulační efekt zátěže ( $\left.\mathrm{K}_{\text {load }}=0\right)$, model turbíny se nahradil členem „lead - lag“ s časovými konstantami $\mathrm{T}_{2}$ a $\mathrm{T}_{3}$ a zesílením $K$.

Pravá část zjednodušeného modelu reprezentuje vlastně pohybovou rovnici (3.2-5), kde skluz $s$ jednoho generátoru nahradila odchylka frekvence $\Delta f$. Levá část je vlastně zjednodušením modelu parní turbíny z Obr. 4.2-1, kde se zanedbalo zpoždění regulačních ventilů a zpoždění vysokotlaké části turbíny $\left(\mathrm{T}_{\mathrm{V}}=\mathrm{T}_{\mathrm{HP}}=0\right)$. Pro ostatní parametry zjednodušeného modelu platí $K=K_{\mathrm{SP}}, \mathrm{T}_{2}=K_{\mathrm{HP}} \mathrm{T}_{\mathrm{R}}, \mathrm{a} \mathrm{T}_{3}=\mathrm{T}_{\mathrm{R}}$.

$\mathrm{K}$ řešení závislosti poměrné odchylky frekvence $\Delta f$ na poměrném výpadku výkonu $\Delta P_{\mathrm{E}}$ použijeme Laplaceovu transformaci. Rovnice má pro jednotkový skok $\Delta P$ (pro zjednodušení zápisu je index e vynechán) tvar:

$$
\Delta f=-\frac{\Delta P}{K}\left[\frac{1}{\mathrm{p}}-\frac{A+\mathrm{p}}{\mathrm{p}^{2}+\frac{\mathrm{p}\left(\mathrm{T}_{\mathrm{M}}+K \mathrm{~T}_{2}\right)}{\mathrm{T}_{3} \mathrm{~T}_{\mathrm{M}}}+\frac{k}{\mathrm{~T}_{3} \mathrm{~T}_{\mathrm{M}}}}\right], \quad A=\frac{1}{\mathrm{~T}_{3}}-\frac{K}{\mathrm{~T}_{\mathrm{M}}}+\frac{K \mathrm{~T}_{2}}{\mathrm{~T}_{3} \mathrm{~T}_{\mathrm{M}}} .
$$

První člen v hranaté závorce představuje ustálené řešení odchylky frekvence a druhý člen přechodnou složku. Časový průběh přechodné složky záleží na řešení charakteristické rovnice, která je ve jmenovateli druhého zlomku. Kořeny charakteristické rovnice jsou bud' dvě reálná čísla, nebo dvě komplexně sdružená čísla $\mathrm{v}$ závislosti na parametrech modelu. Pro reálné kořeny se jedná o aperiodický nárůst nebo pokles odchylky frekvence na ustálenou hodnotu (kořeny jsou vždy záporné). Pro imaginární kořeny je nárůst periodický (s překmitem), reálná část komplexních kořenů je záporná, takže průběhy jsou stabilní. $V$ dalším řešení budeme uvažovat druhý př́ípad komplexně sdružených kořenů $\mathrm{p}_{1,2}$ :

$$
\begin{array}{r}
(\mathrm{p}+\lambda)^{2}+\omega^{2}=0 \Rightarrow \underline{\mathrm{p}}_{1,2}=-\lambda \pm \mathrm{j} \omega \quad \text { pro }\left(1+K \mathrm{~T}_{2} / \mathrm{T}_{\mathrm{M}}\right)^{2}<4 K \mathrm{~T}_{3} / \mathrm{T}_{\mathrm{M}} \\
\lambda=\frac{1+K \mathrm{~T}_{2} / \mathrm{T}_{\mathrm{M}}}{2 \mathrm{~T}_{3}}, \omega=\frac{\sqrt{4 K \mathrm{~T}_{3} / \mathrm{T}_{\mathrm{M}}-\left(1+K \mathrm{~T}_{2} / \mathrm{T}_{\mathrm{M}}\right)^{2}}}{2 \mathrm{~T}_{3}} .
\end{array}
$$

Za těchto podmínek, a pokud turbína pracuje s výkonovou rezervou, která je větší než výpadek výkonu $\Delta P$, je řešení závislosti poměrné odchylky frekvence $\Delta f \mathrm{v}$ časové oblasti:

$$
\Delta f=-\frac{\Delta P}{K}\left[1-\mathrm{e}^{-\lambda \mathrm{t}}\left(\cos \omega \mathrm{t}+\frac{A-\lambda}{\omega} \sin \omega \mathrm{t}\right)\right] .
$$




\section{Př́iklad 4-4}

Zobrazte průběh odchylky frekvence $\Delta$ f z Př́ikladu 4-3 podle vztahu (4.2-5).

\section{Řešení}

Řešení je možno provést v EXCELu. Výpočet se provede v poměrných hodnotách (výkon je vztažen na zatížení soustavy $P_{L}$ ). Konstantu setrvačnosti přepočteme na zatížení soustavy $\mathrm{T}_{\mathrm{M}}=\mathrm{T}_{\mathrm{m}}\left(\mathrm{S}_{\mathrm{n} 1}+\mathrm{S}_{\mathrm{n} 3}\right) / \mathrm{P}_{\mathrm{L}}=5.75 \mathrm{~s}$. Za $K$ je možno dosadit př́mo $K_{\mathrm{T}}=9.857$. Časové konstanty členu „lead - lag“ jsou $\mathrm{T}_{2}=K_{\mathrm{HP}} \mathrm{T}_{\mathrm{R}}=0.25 \cdot 6=1.5 \mathrm{~s}$ a $\mathrm{T}_{3}=\mathrm{T}_{\mathrm{R}}=6 \mathrm{~s}$.

Obr. 4.2-6 ukazuje výsledný průběh odchylky frekvence v pojmenovaných hodnotách.

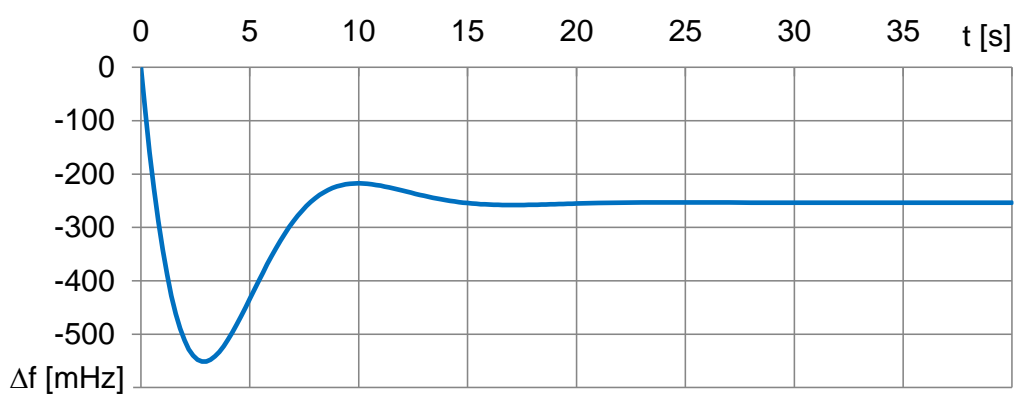

Obr. 4.2-6 Analytický průběh odchylky frekvence $\Delta$ f pro výpadek výkonu $\Delta P=0.05$ ( $\Delta P=500 \mathrm{MW})$

Ke změně výkonu došlo již v čase $\mathrm{t}=0$. Směrnice poklesu frekvence $\mathrm{v}$ prvním okamžiku (tečna $\mathrm{k}$ průběhu $\mathrm{v}$ počátku) je daná velikostí výpadku a časovou konstantou setrvačnosti $\mathrm{T}_{\mathrm{M}}$ $\left(\mathrm{d} f / \mathrm{dt}=\Delta P / \mathrm{T}_{\mathrm{M}}\right)$. Maximální pokles i ustálená hodnota frekvence vychází o něco větší než v simulačním výpočtu vlivem zanedbání regulačního efektu zátěže. Tlumení přechodného děje je obdobné - po jedné periodě kyvů $\left(\mathrm{T}_{\mathrm{K}}=2 \pi / \omega=14.1 \mathrm{~s}\right)$ je dosaženo ustálené hodnoty.

\subsection{Sekundární regulace frekvence a předávaných výkonů (f a P)}

Na proces primární regulace frekvence navazuje sekundární regulace f a P. Na rozdíl od primární regulace, která má decentralizovaný charakter (na odchylku frekvence reagovaly všechny bloky zapojené do primární regulace podle tzv. principu solidarity), má sekundární regulace centralizovaný charakter a je zajišt'ována automaticky sekundárním regulátorem frekvence a předávaných výkonů pro každou regulační oblast. Na centrální regulátor jsou připojeny terminály elektráren s regulačními bloky a terminály v hraničních rozvodnách, kde se měří předávaný výkon (podrobněji viz [4] str. 9).

Regulační odchylku centrálního regulátoru ACE (z angl. „Area Control Error“) tvoří odchylka předávaných výkonů regulační oblasti $\Delta \mathrm{P}_{\mathrm{R}}$ korigovaná odchylkou frekvence $\Delta \mathrm{f}$ :

$$
\mathrm{ACE}=\Delta \mathrm{P}_{\mathrm{R}}-\mathrm{K}_{\mathrm{R}} \Delta \mathrm{f},
$$

$\Delta \mathrm{P}_{\mathrm{R}}$ odchylka předávaných výkonů jako rozdíl plánovaného salda PPLAN a okamžitého součtu měřených toků výkonů po hraničních vedeních (kladné hodnoty odpovídají exportu),

$\mathrm{K}_{\mathrm{R}}$ nastavený parametr regulátoru (tzv. K-faktor), který by se měl rovnat výkonovému číslu regulační oblasti, aby platil tzv. princip neintervence.

Centrální regulátor pracuje podle metody sít’ových charakteristik, která zajišt'uje princip neintervence. To znamená, že způsobenou výkonovou nerovnováhu, projevující se změnou frekvence a odchylkou předávaných výkonů, vyrovnává pouze postižená regulační oblast (kde výkonová nerovnováha vznikla) a zároveň regulátor nepostižené oblasti neodregulovává odchylku výkonu vzniklou prŕspěvkem primární regulace frekvence. 


\section{Př́íklad 4-5}

V soustavě z Obr. 4.3-1 došlo v oblasti B k výpadku výkonu 1300 MW. Každá oblast je modelována jedním uzlem s agregovanou spotřebou i výrobou. Ekvivalentní bloky BLOK1 a BLOK3 poskytují primární regulaci se stejnou statikou a zároveň jsou připojeny k centrálnímu regulátoru, který mění jejich zadaný výkon. Ve výchozím stavu je předávaný výkon nulový (obě oblasti si pokrývají svá zatížení). Zanedbejte regulační efekty zátěže a zjistěte průběhy frekvence a výkony regulačních bloků za předpokladu, že zadané K-faktory regulátorů odpovídají výkonovým číslům regulačních oblastí $\mathrm{K}_{\mathrm{R}}=\mathrm{K}_{\mathrm{P}}$.

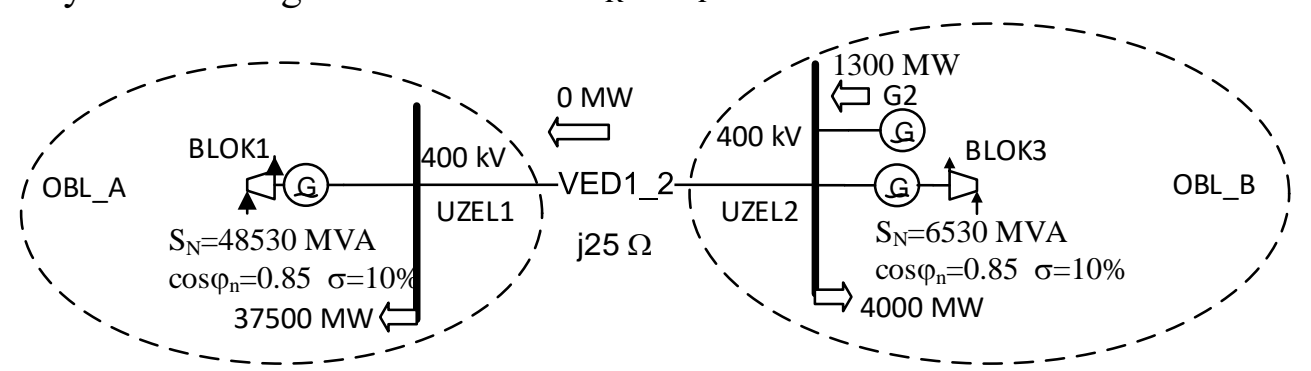

Obr. 4.3-1 Model dvou regulačních oblastí

Př́íklad byl s úpravami převzat z knihy [34] („Example 9.2“ str. 367).

\section{$\underline{\text { Řšení }}$}

Zjistíme nejprve výkonová čísla obou soustav. Jelikož se regulační efekt zátěže zanedbává, je výkonové číslo oblasti rovno výkonovému číslu primární regulace $K_{P}$ podle (4.2-2) neboli: $\mathrm{K}_{\mathrm{PA}}=2 \mathrm{~S}_{\mathrm{nA}} \cos \varphi_{\mathrm{nA}} / \sigma_{\mathrm{A}}=8250 \mathrm{MW} / \mathrm{Hz}$ a $\mathrm{K}_{\mathrm{PB}}=2 \mathrm{~S}_{\mathrm{nB}} \cos \varphi_{\mathrm{nB}} / \sigma_{\mathrm{B}}=1110 \mathrm{MW} / \mathrm{Hz}$.

Pro řešení je vhodný sít’ový simulátor MODES, kde se v projektu FRK_STAB otevře prŕpad UST2AREA, který zahrnuje dvouuzlový chod sítě se třemi zdroji, které mají definované dynamické modely (klasické modely generátorů s parametry G3P z Tab. 3.2-5 a standardní model turbíny a regulátoru s parametry $S T$ S a SCoC10 (z Tab. 4.2-2 a Tab. 4.2-1). Př́ípad má také definovány centrální regulátory obou oblastí, jejichž schéma je zobrazeno na Obr. 4.3-2.

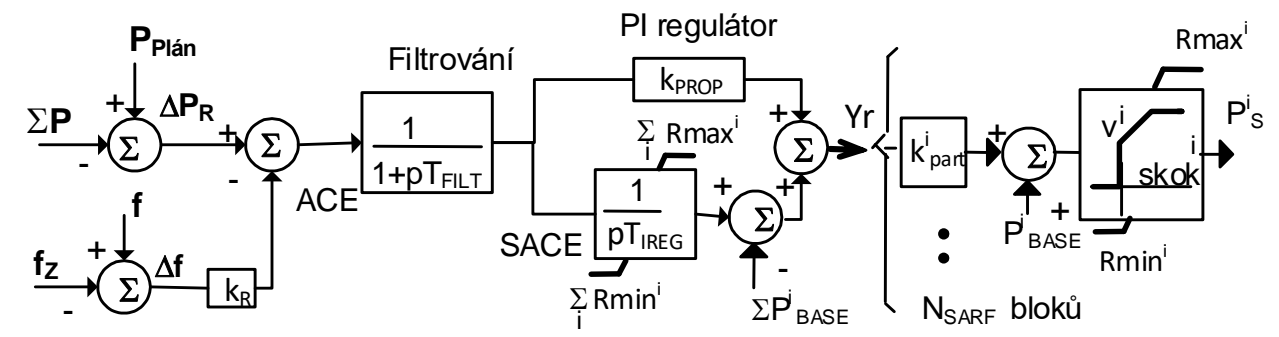

Obr. 4.3-2 Blokové schéma modelu centrálního regulátoru f a $P$

Regulační odchylka ACE vstupuje po odfiltrování šumů do PI regulátoru. Výstup regulátoru Yr je přes participační koeficient rozdělen mezi jednotlivé regulační bloky (v našem prŕípadě má centrální regulátor jeden regulační blok). Každý regulační blok má zadánu svoji rychlost zatěžování v. Výstup omezovače rychlosti zatěžování $P_{S}$ vstupuje po přepočtu na jmenovitý výkon turbíny jako vstupní hodnota $N_{S} v$ modelu turbíny (viz Obr. 4.2-1).

Parametry modelu centrálního regulátoru a regulačních bloků, uložené ve vstupním souboru AUTSEK.001, jsou v tomto výpisu:

\begin{tabular}{|c|c|c|c|c|c|c|c|c|c|c|c|}
\hline Jmeno & $\mathrm{K}_{\mathrm{R}}$ & & Tsamp 7 & Tfilt & $\mathrm{Kpr}$ & rop Tire & eg necR & Nsarf & frad Plan & Jmeno & \\
\hline oblasti & {$[\mathrm{MW} / \mathrm{H}$} & $\mathrm{Hz}$ ] & {$[\mathrm{sec}]$} & {$[\mathrm{sec}]$} & {$[-]$} & {$[\mathrm{sec}]$} & ] [MW ] & {$[-]$} & $\underset{\text { Nsecx }}{[\mathrm{Hz}] \quad[\mathrm{MW}]}$ & profilu & uzlu pro mereni f \\
\hline$\overline{' O B L \_A}$ & 8250 & & 1 & $0 . \overline{1}$ & 1 & 100 & 0 & 1 & $\overline{50} \quad 0$ & 'P 1-2' & 'UZEL1' \\
\hline 'OBL_B' & 1110 & & 1 & 0.1 & 1 & 90 & 0 & 1 & 50 & 'P $1-2 \mathrm{~K}^{\prime}$ & 'UZEL2' \\
\hline $\begin{array}{l}\text { jmeno } \\
\text { bloku }\end{array}$ & $\begin{array}{r}\text { nec } 1 \\
{[\mathrm{MW}]}\end{array}$ & $\begin{array}{l}\mathrm{KC} \\
{[1]}\end{array}$ & $\begin{array}{l}\text { Kpart } \\
{[\%]}\end{array}$ & $\begin{array}{r}\mathrm{Rmin} \\
{[\mathrm{MW}]}\end{array}$ & $\begin{array}{c}R \max \\
{[\mathrm{MW}]}\end{array}$ & $\begin{array}{l}\text { necNR } \\
{[\mathrm{MW}]}\end{array}$ & $\begin{array}{l}\text { skokNR } \\
{[\text { MW ] }} \\
\text { (Nsarf1+ }\end{array}$ & $\begin{array}{r}\text { trenc } \\
{[\mathrm{MW} / \mathrm{n}} \\
\ldots \text { Nsarfl }\end{array}$ & $\begin{array}{l}\text { d zatezovan } \\
\text { min] } \\
\text { Nsec) } x\end{array}$ & & \\
\hline$\overline{\text { 'BLOK1' }}$ & 20 & 1 & 100 & $\overline{20000}$ & $\overline{41250}$ & 0 & 10 & 800 & & & \\
\hline 'BLOK3' & 20 & 1 & 100 & 2500 & 5551 & 0 & 10 & 220 & & & \\
\hline
\end{tabular}


Délka výpočtu $200 \mathrm{~s}$ (se vzorkováním $1 \mathrm{~s}$ ) je přizpůsobena dlouhodobé dynamice. Jelikož nejsou definovány specifické modely zátěží, je odběr modelován jako konstantní admitance (neboli závislý na kvadrátu napětí v uzlu). V grafice jsou zadány proměnné SU (pro odchylku frekvence), tok činného výkonu PP hraničním profilem P1-2 (profily jsou vygenerovány automaticky při přepočtu chodu sítě, v našem jednoduchém dvouuzlovém modelu tvoří profil př́mo hraniční vedení VED1-2) a výkony generátoru PG a turbíny NT pro oba regulační bloky.

Ve scénáři je již zadán zásah AUTO na aktivace obou centrálních regulátorů (objekt LFC), pro simulaci výpadku stačí zadat v $\mathrm{t}=10 \mathrm{~s}$ zásah UNIT pro objekt $\mathrm{G} 2$ parametrem 0 .

Obr. 4.3-3 ukazuje průběhy odchylky frekvence a toku na profilu mezi oblastmi.
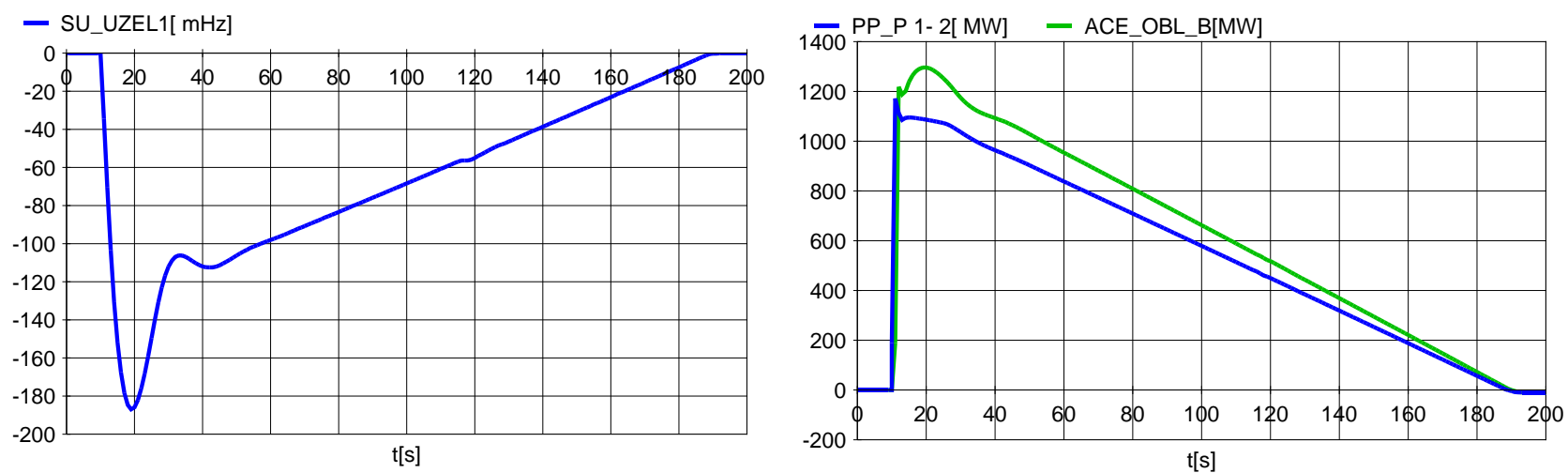

Obr. 4.3-3 Průběhy odchylky frekvence SU, toku činného výkonu profilem PP a regulační odchylky ACE

V levém grafu je vidět nejprve známý průběh odchylky frekvence během primární regulace a pak postupné odregulování odchylky frekvence činností sekundární regulace. V levém grafu je vidět skokový nárůst toku profilu daný rázem činného výkonu na BLOK1 a poté solidární výpomoc regulační oblasti $O b{ }_{1}$ A postižené regulační oblasti $O b{ }_{-} B$, kde došlo k výpadku. Regulátor odreguluje za pomoci bloku BLOK3 výpadek během 3 minut.

Obr. 4.3-4 ukazuje průběhy výkonů obou regulačních bloků.
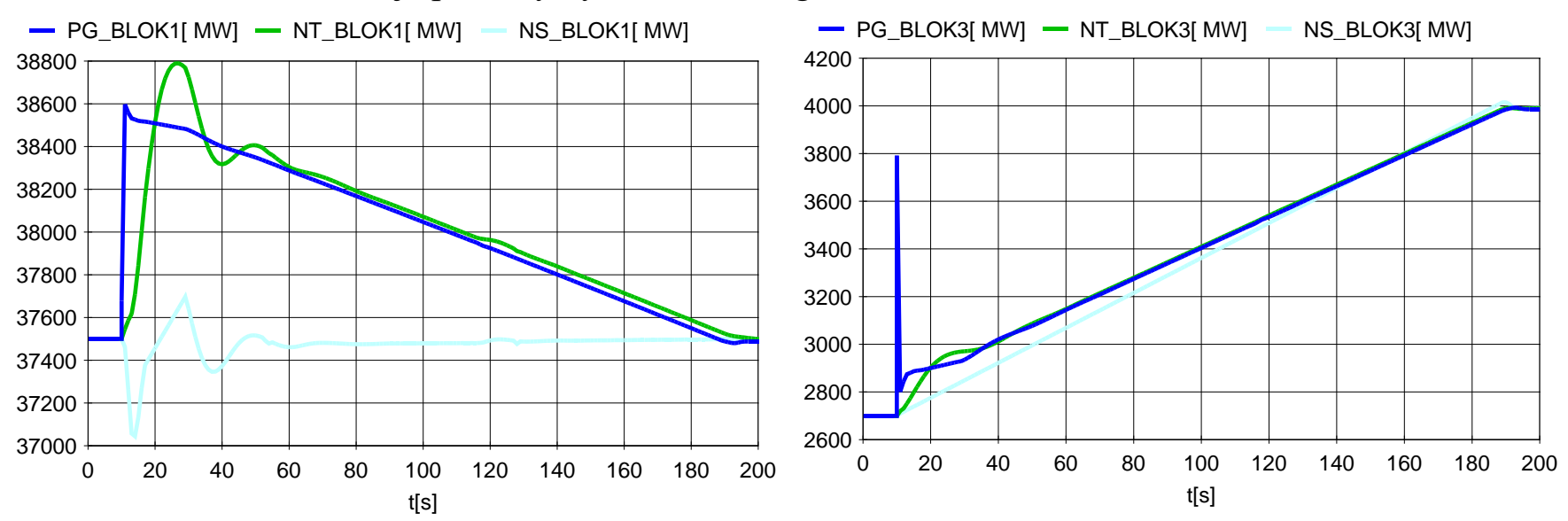

Obr. 4.3-4 Průběhy výkonů generátorů PG, požadovaných a skutečných výkonů turbíny NS a NT

Na průbězích výkonů PG jsou vidět rázy činného výkonu. Nárůst výkonu turbíny NT bloku BLOK1 je dán činností primární regulace (na základě principu solidarity) a odchylkou frekvence. Nárůst výkonu turbíny bloku BLOK3 je dán především činností centrálního regulátoru, který nahrazuje výpadek výkonu ve své regulační oblasti.

Dosavadní výpočty předpokládaly, že výkonové rezervy pro primární a sekundární regulaci jsou větší, než je výpadek výkonu, takže postačí k obnovení výkonové rovnováhy mezi odběrem zátěže a výkonem zdrojů (pohonů synchronních generátorů). Pokud tento předpoklad splněn nebude, je nutno zajistit výkonovou rovnováhu opatřeními na straně zatížení. Toto opatření se nazývá frekvenční odlehčování zátěže. 


\subsection{Frekvenční odlehčování zátěže}

Frekvenční odlehčování zátěže znamená vypnutí části zatížení při poklesu frekvence pod zadanou mez. V př́iloze Nařízení EU [36] je stanoven minimální počet stupňů pro frekvenční odlehčování na 6 , přičemž první stupeň má při poklesu frekvence na $49 \mathrm{~Hz}$ odpojit minimálně $5 \%$ zátěže ${ }^{1}$. Poslední stupeň má působit při $48 \mathrm{~Hz}$ a zajistit minimálně odpojení $45 \%$ zátěže. Maximální objem odlehčení v jednom stupni nemá překročit $10 \%$. Působení frekvenčního odlehčování si ukážeme na př́íkladu.

\section{Př́íklad 4-6}

V soustavě z Obr. 4.2-3 došlo k výpadku generátoru G3. Generátor G1 pokrývá $60 \%$ zatížení a zajištuje primární regulaci celé soustavy se statikou $\sigma=7 \%$ a výkonovou rezervou 15 $\%$. Generátor G2 pracuje na konstantní výkon $500 \mathrm{MW}$. Uvažujte regulační efekt zátěže $K_{\mathrm{L}}=1$ (při poklesu frekvence o $1 \%$ klesne zatížení také o $1 \%$ ). Zjistěte průběh frekvence pro:

a) případ bez frekvenčního odlehčování zátěže,

b) př́pad s čtyřstupňovým frekvenčním odlehčováním podle tabulky s dobou náběhu $0.1 \mathrm{~s}$,

c) př́ipad s šestistupňovým frekvenčním odlehčováním podle tabulky s dobou náběhu $0.1 \mathrm{~s}$.

Tab. 4.4-1 Nastavení frekvenčního odlehčování zátěže

\begin{tabular}{|l|l|l|l|l|l|l|l|}
\hline př́ípad & stupeň & 1. & 2. & 3. & 4. & 5. & 6. \\
\hline \multirow{3}{*}{ b) } & Fzad[Hz] & 49 & 48.7 & 48.4 & 48.1 & & \\
\cline { 2 - 8 } & objem [\%] & 12 & 12 & 12 & 14 & 4 & 8 \\
\hline \multirow{2}{*}{ c) } & Fzad [Hz] & 49 & 48.8 & 48.6 & 48.4 & 48.2 & 48 \\
\cline { 2 - 8 } & objem [\%] & 5 & 8 & 8 & 8 & 8 & 8 \\
\hline
\end{tabular}

Doba náběhu definuje dobu, po kterou musí frekvence zůstat pod zadanou mezi Fzad.

\section{Řešení}

Časový průběh frekvence po výpadku bloku G3 zjistíme simulačním výpočtem na dynamickém modelu. Předpokládejme, že výsledky řešení Př́ikladu 4.3 byly uloženy jako samostatný případ a vyjdeme $z$ tohoto prrípadu, který má definovány již potřebné modely bloků i zátěže bez frekvenčního odlehčování.

Vytvoříme novou variantu scénáře, kde místo výpadky bloku G2 zadáme blok G3.

Na Obr. 4.4-1 jsou výkony bloku a odchylka frekvence (odpovídá skluzu generátoru).
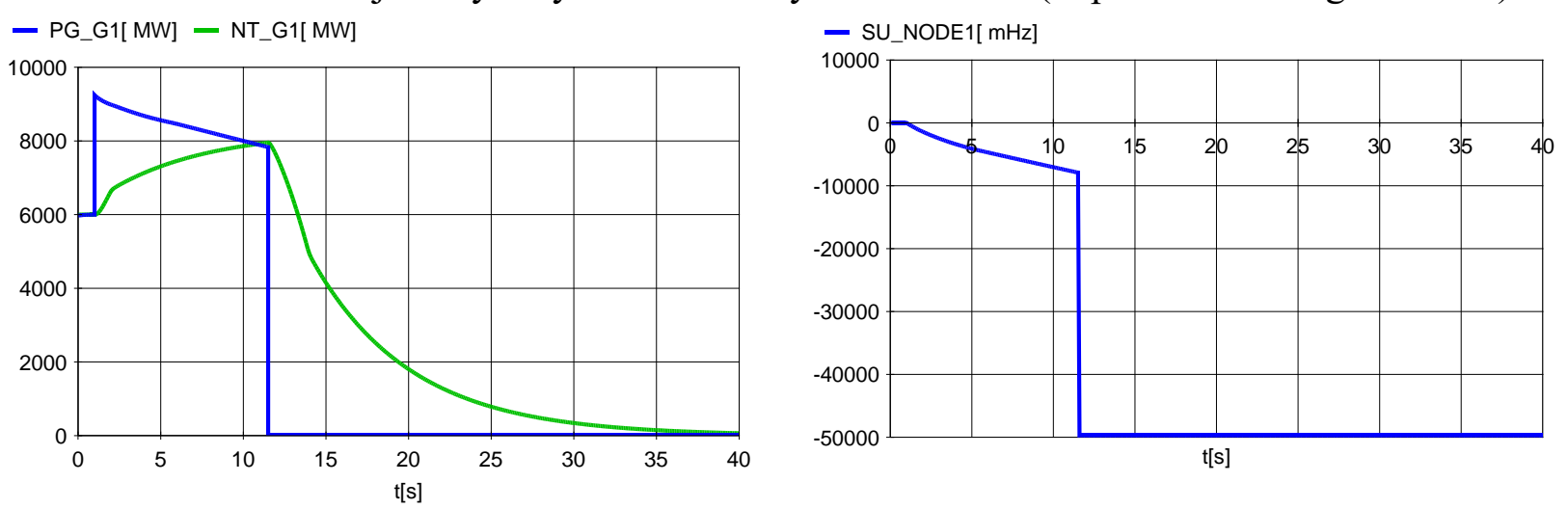

Obr. 4.4-1 Průběhy výkonů generátoru a turbíny a odchylky frekvence po výpadku bloku GEN3

V levém grafu je vidět ráz činného výkonu a nárůst výkonu turbíny NT jako reakci na pokles otáček. Ten je patrný z pravého grafu ve formě odchylky frekvence. Při poklesu pod $10 \%$ jsou bloky automaticky odpojeny od sítě a soustava skončí bez napětí v blackoutu.

\footnotetext{
${ }^{1} \mathrm{~V}$ českém překladu Nařízení se objevil nový termín pro spotřebu, odběr nebo zatížení a to poptávka, což je výraz spíše obchodně - ekonomický než technický. Proto budeme i nadále používat termín frekvenční odlehčování zátěže.
} 
Nyní (po uložení případu) můžeme přikročit k řešení případu s čtyřstupňovým frekvenčním odlehčováním, které je nutno v uzlu NODE4 definovat. K tomu použijeme editor databázi dynamických modelů uzlu (ㅇ.), Ze seznamu uzlů vybereme NODE4 a stiskneme tlačítko Frekvenční odlehčování zátěže. Z tabulky vybereme sadu typových parametrů UCPTE a stiskneme tlačítko Vyměnit parametry. Nakonec zadáme objemy odlehčení 12, 12, 12 a 14 \% pomocí jezdců vpravo s potvrzením tlačítkem Změnit objem. Tlačítkem OK změny uložíme s potvrzením vzniku nové modifikace. Aktivaci změněného záznamu databáze dokončíme otevřením v textovém režimu z menu Modifikovat/Modely uzlů při nezaškrtnuté volbě Databáze. Počet uzlů opravíme na 1. Výpis modifikované databáze ukazuje následující rámeček.

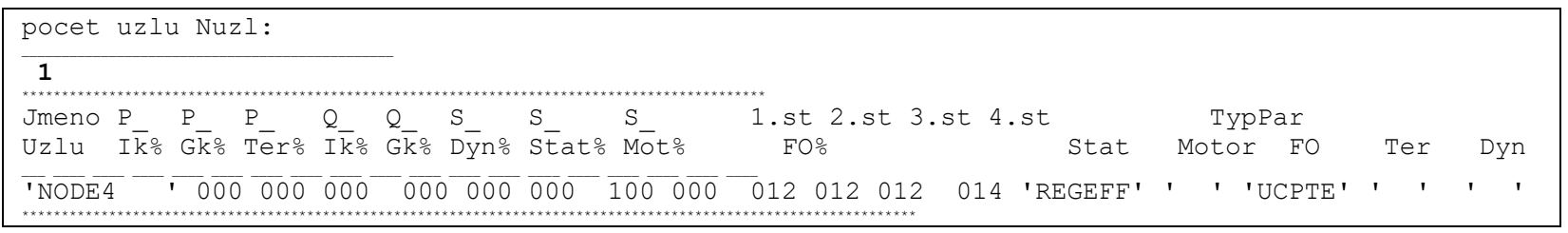

Na Obr. 4.4-3 jsou výkony bloku a odchylka frekvence po působení frekvenčního odlehčování jako výsledek simulačního výpočtu.
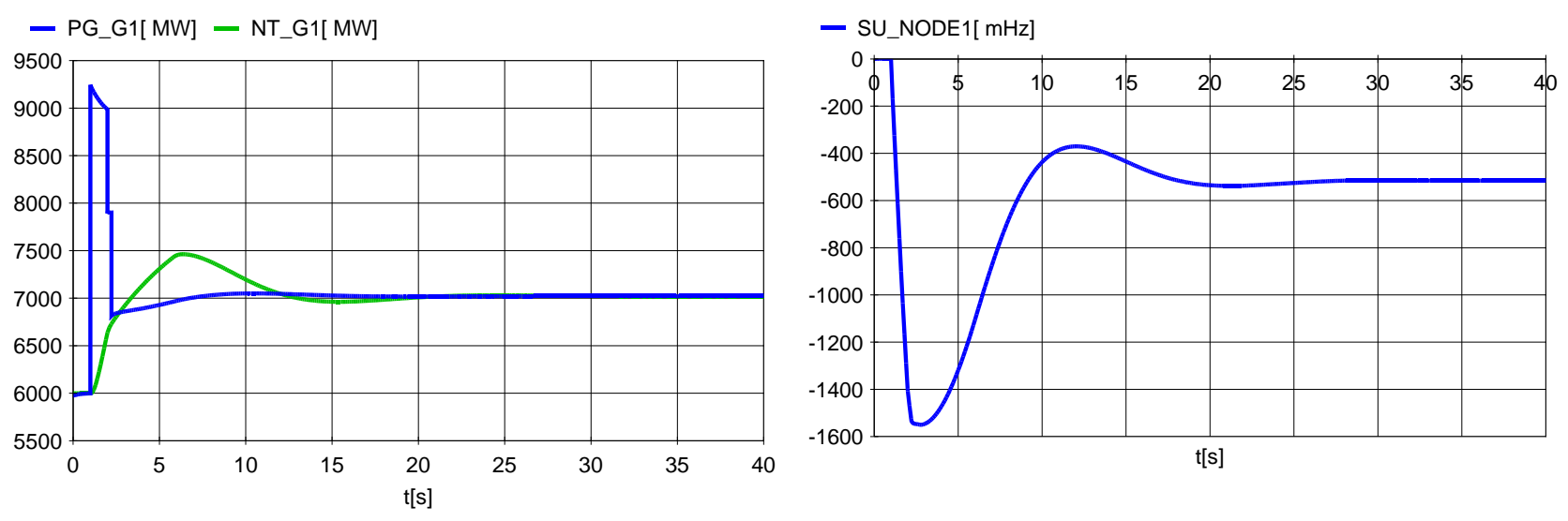

Obr. 4.4-2 Průběhy výkonů a odchylky frekvence s čtyřstupňovým frekvenčním odlehčováním

V levém grafu je vidět opět ráz činného výkonu a nárůst výkonu turbíny NT jako reakci na pokles otáček. Tentokrát ovšem po působení prvních dvou stupňů frekvenčního odlehčování se výkon generátoru zmenší a během $25 \mathrm{~s}$ se výkon turbíny přizpůsobí výkonu zatížení a frekvence se ustálí na hodnotě kolem $49.5 \mathrm{~Hz}$.

Výkonový deficit kolem $3500 \mathrm{MW}$ tedy byl pokryt přibližně takto:

1. frekvenčním odlehčováním (přibližně $2400 \mathrm{MW}$ ),

2. regulačním efektem zátěže (kolem $85 \mathrm{MW}$ ) a

3. regulací turbíny na bloku G1 (asi $1015 \mathrm{MW}$ ).

Toto čtyřstupňové frekvenční odlehčování bylo standardně zavedeno v ES ČR jako podmínka pro připojení $\mathrm{k}$ tehdejšímu propojení UCPTE.

Nyní prověříme chování soustavy s šestistupňovým frekvenčním odlehčováním. Pro změnu čtyřstupňového na šestistupňové je potřeba znovu modifikovat dynamický model uzlu. Již známým způsobem otevřeme Editor databáze dynamických modelů uzlů. Ze seznamu uzlů vybereme NODE 4 a stiskneme tlačítko Frekvenční odlehčování zátěže. Nejprve vytvoříme novou sadu typových parametrů. $\mathrm{V}$ tabulce klikneme na poslední prázdný rádek s hvězdičkou v levém sloupci. Pak stiskneme tlačítko Přidat novou sadu a původní sada parametrů UCPTE se zkopíruje do tohoto řádku. Přjejmenujeme ji na 6STUP a opravíme mezní frekvence pro první čtyři stupně podle Tab. 4.4-1. Definici dalších zbývajících dvou stupňů Editor neumožňuje a dokončíme ji $\mathrm{v}$ textovém režimu. Doplníme ještě komentář k nově vytvořené sadě a za vykřičník do sloupce Koment dopíšeme Šestistupňové odlehčování. Pro uložení změn do paměti skočíme o řádek výše 
a vrátíme se zpět. Stiskem tlačítka Vyměnit parametry se pro frekvenční odlehčování v uzlu NODE4 přiřadí tato sada parametrů. Ještě upravíme objemy odlehčování pro první čtyři stupně pomocí jezdců vpravo a po potvrzení změny objemu novou modifikaci uložíme tlačítkem OK.

Pro dodefinování zbývajících dvou stupňů frekvenčního odlehčování využijeme textový režim editace vstupních dat. Doplníme nejprve katalog typových parametrů modelu sítě TYP_SIT.CAT. Z menu Modifikovat/Katalogy sítě při nezaškrtnuté volbě Databáze se otevřou dva katalogy - globální (uložený ve složce GLOBAL.DAT) a lokální (uložený ve složce VST). Globální katalog slouží všem projektům, a proto se nedoporučuje měnit. Námi vytvořená nová sada je uložena v lokálním katalogu, který slouží jen danému projektu. Takže v něm najdeme sekci frekvenčního odlehčování a na konec záznamu sady 6STUP dopíšeme data pro pátý a šestý stupeň (dvě dvojice Fzad - mezní frekvence a Tnab - doba náběhu) jak ukazuje výpis:

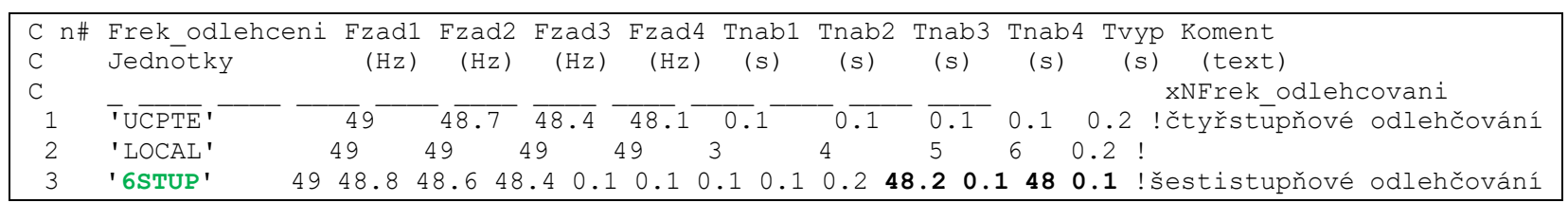

Změny uložíme a zbývá opravit vstupní soubor s databází modelů uzlů. To provedeme z menu Modifikovat/Modely uzlů. Ve zvoleném textovém editoru (doporučuje se program TextPad) se otevřou dva soubory - výchozí databáze UZLY.DTB a její modifikace UZLY.002. V záznamu pro uzel NODE4 doplníme objemy zbývajících dvou stupňů odlehčování, takže záznam bude vypadat takto:

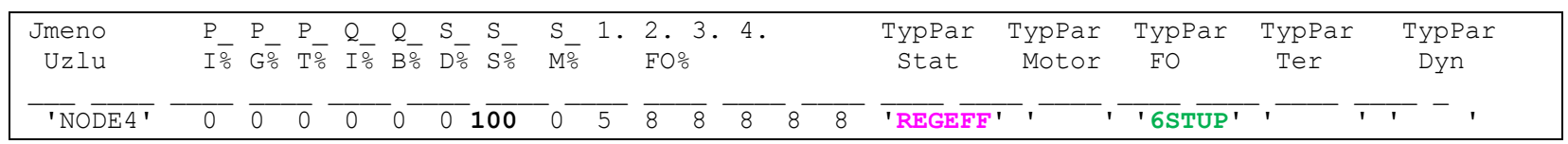

Po uložení a po spuštění simulačního výpočtu je možno zobrazit výsledky.
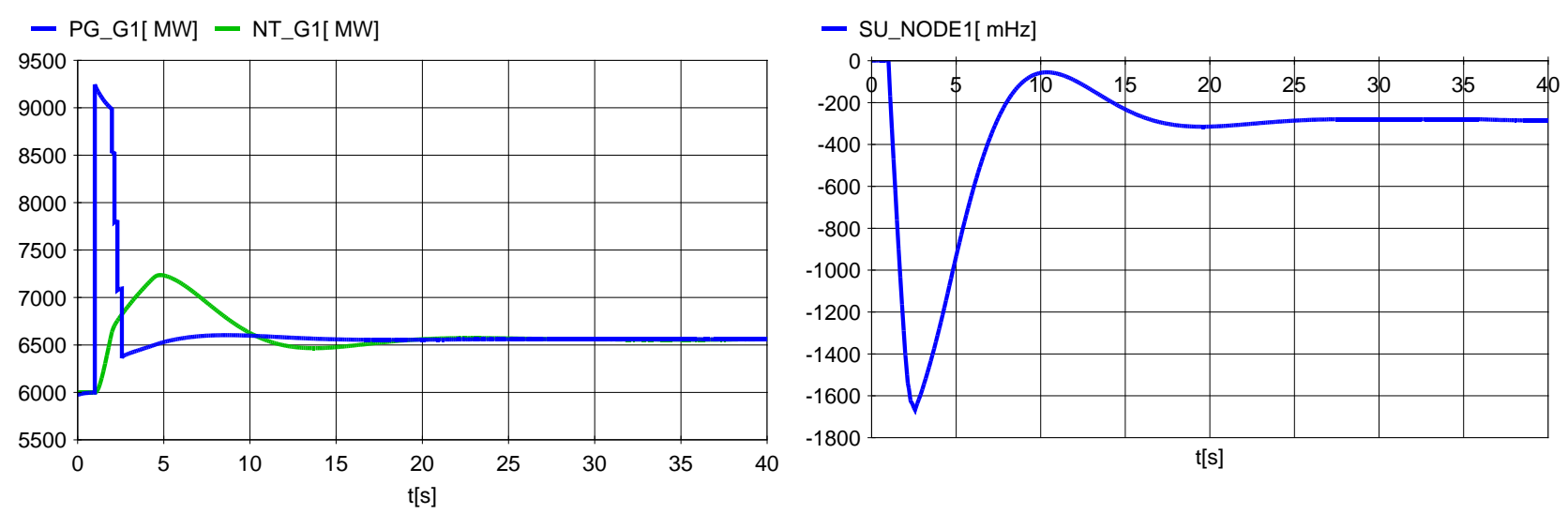

Obr. 4.4-3 Průběhy výkonů a odchylky frekvence s šestistupňovým frekvenčním odlehčováním

$\mathrm{Z}$ průběhu činného výkonu generátoru je vidět, že působily čtyři stupně frekvenčního odlehčování. Frekvence se ustálí na hodnotě kolem 49.7 Hz. Výkonový deficit kolem 3500 MW tedy byl pokryt frekvenčním odlehčováním (přibližně 2900 MW), regulačním efektem zátěže (kolem $50 \mathrm{MW}$ ) a regulací turbíny na bloku G1 $550 \mathrm{MW}$. Při šestistupňovém odlehčování bylo vypnuto více zatížení než při čtyřstupňovém (2900 versus 2400 MW) za cenu nižší ustálené odchylky frekvence $(0.3$ versus $0.5 \mathrm{~Hz})$.

\subsection{Kontrolní otázky}

1. Co se rozumí výkonovou rovnováhou v souvislosti s frekvenční stabilitou?

2. Co je to výkonové číslo soustavy?

3. Co jsou principy solidarity a neintervence? 


\section{Napět'ová stabilita}

Napětovou stabilitu je možno definovat jako schopnost soustavy udržet napětí při nárůstu zatížení (viz např. [37]). Klasické vysvětlení napětové stability obvykle začíná u tzv. nosových křivek, které určují maximálně přenositelný činný výkon přes vedení.

\subsection{Nosové křivky}

Provedeme si zjednodušené odvození nosových křivek pro ideální vedení bez odporu a kapacity, napájené $\mathrm{z}$ jedné strany zdrojem konstantního napětí $\mathrm{E}$ a $\mathrm{z}$ druhé strany zatížené odebíraným výkonem $\underline{S}=\mathrm{P}+\mathrm{jQ}$, který nezávisí na napětí konce vedení U. Jednopólové schéma $\mathrm{v}$ poměrných hodnotách a fázorový (vektorový) diagram je na Obr. 5.1-1.
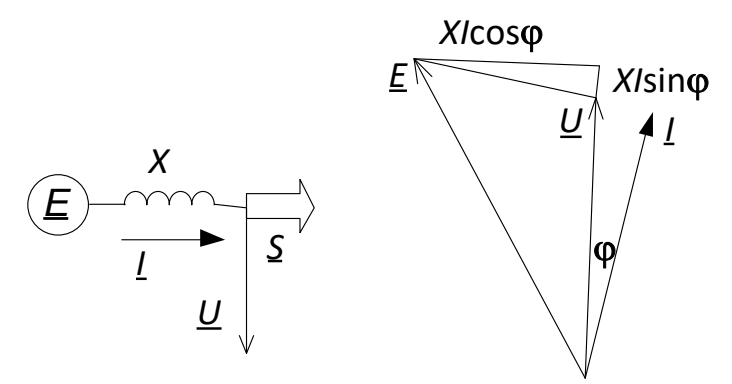

Obr. 5.1-1 Schéma přenosu výkonu $\underline{S}$ přes admitanci $X$ pro odvození nosových křivek

$\mathrm{Z}$ fázorového diagramu plyne napětová rovnice ve tvaru:

$$
E^{2}=(U+X I \sin \varphi)^{2}+(X I \cos \varphi)^{2}
$$

Po dosazení za činný výkon $P=U I \cos \varphi$, substitucích $\mathrm{Y}=P X$ a $\mathrm{A}=U^{2}$ a za předpokladu $E=1$ obdržíme kvadratickou rovnici a její řešení ve tvaru:

$$
\begin{gathered}
\mathrm{A}^{2}+\mathrm{A}(2 \mathrm{Y} \operatorname{tg} \varphi-1)+\mathrm{Y}^{2}\left(1+\operatorname{tg}^{2} \varphi\right)=0, \\
\mathrm{~A}=\frac{1-2 \mathrm{Ytg} \varphi \pm \sqrt{1-4 \mathrm{Y} \operatorname{tg} \varphi-4 \mathrm{Y}^{2}}}{2} .
\end{gathered}
$$

Řešení je ve formě nosových křivek pro tři různé účiníky $\cos \varphi$ zobrazeno na Obr. 5.1-2.

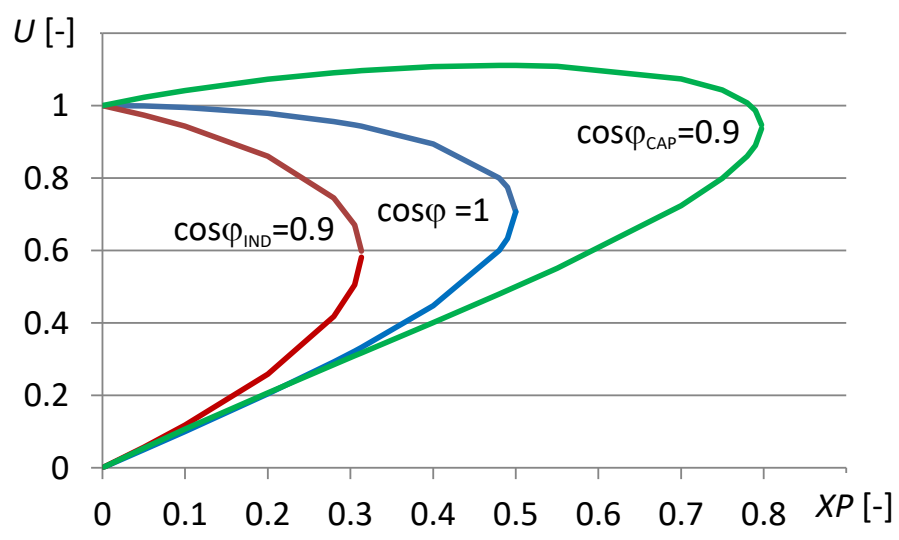

Obr. 5.1-2 Nosové křivky pro $E=1$

Podle rovnice (5.1-1) je maximální poměrný přenositelný výkon $P_{\max }$ přes reaktanci $X$ pro jmenovitá napětí $E=U=1$ rovný $P_{\max }=1 / X$. Z modré nosové křivky pro účiník $\cos \varphi=1$ vyplývá, že za předpokladů, za kterých byly nosové křivky odvozeny (konstantní napětí na začátku a odběr výkonu nezávislý na napětí) lze přenést maximálně polovinu tohoto výkonu. Př̀ induktivním odběru jalového výkonu je tato hodnota ještě nižší. Nekontrolovatelný pád napětí při zvyšování odběru činného výkonu se také nazývá napět'ový kolaps. 


\subsection{Kritérium $\mathrm{d} \Delta \mathrm{Q} / \mathrm{dU}$}

Nosové křivky byly odvozeny za předpokladu, že odběr činného a jalového výkonu zátěže nezávisí na napětí. Ve skutečnosti tomu tak být nemusí a ani nebývá. Pro napětovou stabilitu hraje závislost odběru výkonu na napětí klíčovou roli, proto se jí také někdy ř́ká stabilita zátěže. Ukážeme si vliv zátěže na napět’ovou stabilitu s uvážením statických charakteristik ve tvaru:

$$
\begin{array}{r}
Q_{L}=Q_{n}\left[B_{Q}\left(\frac{U}{U_{n}}\right)^{2}+A_{Q}\left(\frac{U}{U_{n}}\right)+1-B_{Q}-A_{Q}\right], \\
P_{L}=P_{n}\left[B_{P}\left(\frac{U}{U_{n}}\right)^{2}+A_{P}\left(\frac{U}{U_{n}}\right)+1-B_{P}-A_{P}\right],
\end{array}
$$

$P_{n}$ a $Q_{n}$ jsou odběry zátěže při jmenovitém napětí $U_{n}$. První dvě složky výkonu závisí na napětí kvadraticky a lineárně. Kvadratickou závislost má odporová zátěž (žárovky nebo topná tělesa).

Nyní provedeme analýzu napájení statické zátěže ze střídavé sítě, ve které můžeme zanedbat činné odpory a uvažovat jen reaktance. Náhradní schéma takové sítě je na Obr. 5.1-1, kde odběr zátěže je $\underline{S}=P_{L}+j Q_{L}$. Zdroj E je schopen dodat do místa zátěže činný a jalový výkon:

$$
\mathrm{P}_{\mathrm{S}}=\frac{\mathrm{EU}}{\mathrm{X}} \sin \delta, \quad \mathrm{Q}_{\mathrm{S}}=\frac{\mathrm{EU}}{\mathrm{X}} \cos \delta-\frac{\mathrm{U}^{2}}{\mathrm{X}} \text {. }
$$

Vztah pro činný výkon $P_{s}$ je již známý z úhlové stability (analogie s rovnicí (3.1-1), je zátěžný úhel $\delta$ ). Pro napět’ovou stabilitu je důležitý jalový výkon. Proto se budeme zabývat podrobněji jím. Další odvození kritérií napět’ové stability je př́ejato z knihy [22] str. 305.

Klasické kritérium napětové stability zní:

$$
\frac{\mathrm{d}\left(\mathrm{Q}_{\mathrm{S}}-\mathrm{Q}_{\mathrm{L}}\right)}{\mathrm{dU}}<0, \quad \frac{\mathrm{dQ} \mathrm{S}}{\mathrm{dU}}<\frac{\mathrm{dQ}_{\mathrm{L}}}{\mathrm{dU}} .
$$

Nejlépe se toto kritérium vysvětlí graficky. Napřed sestrojíme závislost Qs na napětí U. Vyjdeme z rovnic (5.2-2), vyloučíme z nich zátěžný úhel $\delta$ a obdržíme závislost:

$$
Q_{\mathrm{S}}=\sqrt{\left(\frac{E U}{X}\right)^{2}-P_{L}^{2}}-\frac{U^{2}}{X} .
$$

kde za $\mathrm{P}_{\mathrm{S}}$ jsme rovnou dosadili př́mo výkon zátěže $\mathrm{P}_{\mathrm{L}}$, protože během přenosu nedochází ke ztrátám činného výkonu a výkon zdroje se musí rovnat výkonu zátěže.

Závislost $\mathrm{Q}_{\mathrm{s}}$ na $\mathrm{U}$ tvoří pro $\mathrm{P}_{\mathrm{L}}=0$ obrácenou parabolu s maximem rovným $E^{2} / 4 X$ pro $\mathrm{U}=\mathrm{E} / 2$. Pro nenulový činný výkon $\mathrm{P}_{\mathrm{L}}$ se křivka posouvá doprava a dolů, jak ukazuje Obr. 5.2-1, kreslený v poměrných hodnotách pro $E=1 \mathrm{a} X=0.5$.

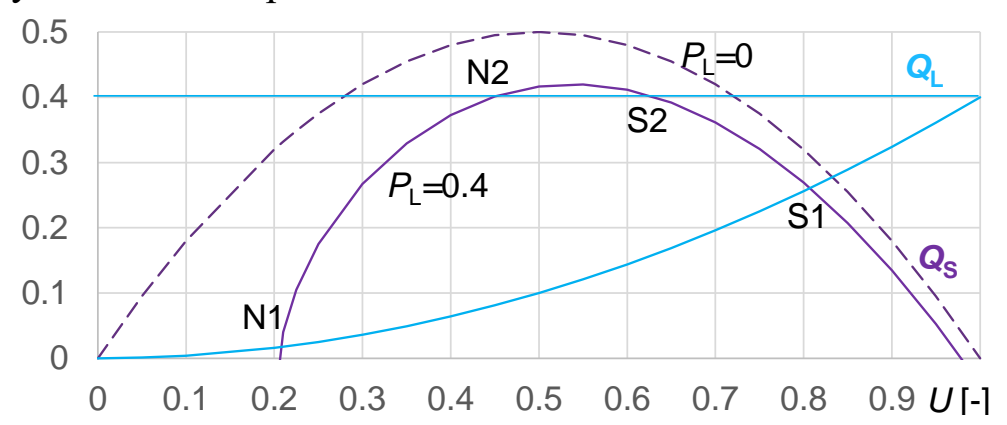

Obr. 5.2-1 Závislosti jalového výkonu dodávaného zdrojem $Q_{S}$ a odebíraného zátěží $Q_{L}$ na napětí

Světlemodře jsou kresleny křivky pro konstantní a kvadratickou závislost zátěže QL. Křivky $Q_{L}$ a $Q_{S}$ (pro $P_{L}>0$ ) se protínají ve čtyřech bodech, $z$ nichž ty napravo (značené $S$ ) jsou stabilní - jsou v nich splněny nerovnosti (5.2-3). 
Naopak body nalevo (značené N) jsou nestabilní. To se dá vysvětlit tak, že například v bodě N1 klesne nepatrně napětí, což způsobí zmenšení dodávky jalového výkonu ze zdroje, deficit jalového výkonu a další pokles napětí.

Pro mez napět'ové stability jsou si derivace závislosti QL a Qs na napětí rovny. V grafickém vyjádření jsou si v kritickém bodě rovny tečny ke křivkám QL a Qs.

\section{Př́klad 5-1}

Pro soustavu z Obr. 5.2-2 zjistěte, při jakém nárůstu zátěže $\xi$ dojde k dosažení meze napětové stability podle kritéria $\mathrm{d} \Delta \mathrm{Q} / \mathrm{dU}=0$. Charakteristiky zátěže uvažujte ve tvaru $\mathrm{Q}_{\mathrm{L}}=\xi 100\left(5.9 U^{2}-9.5 U+4.6\right)$ a $\mathrm{P}_{\mathrm{L}}=\xi 150 U$ v závislosti na poměrném napětí $U$.

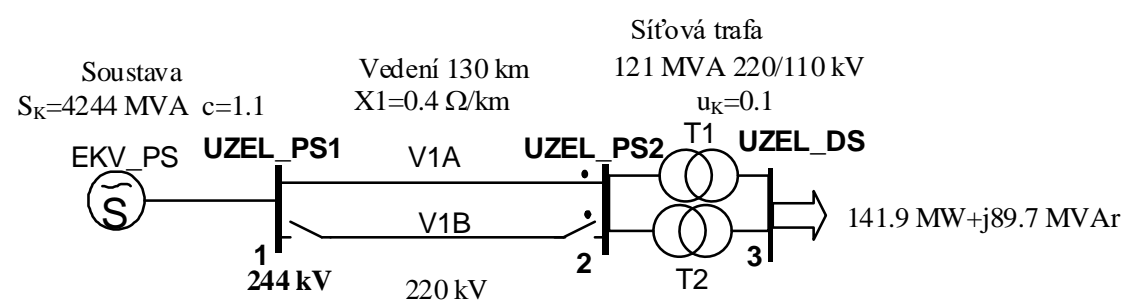

Obr. 5.2-2 Model zátěže napájené z jednoho zdroje pro výpočet napět'ové stability

Př́iklad byl s úpravami převzat z knihy [34] („Example 8.1“ str. 313). Zdroj je zadán jako soustava se zadaným zkratovým výkonem $\mathrm{S}_{\mathrm{K}}$ a napětovým součinitelem c (viz [38] str. 53).

ŘRešení

Řešení provedeme v poměrných hodnotách. Náhradní schéma sítě je na Obr. 5.2-3.

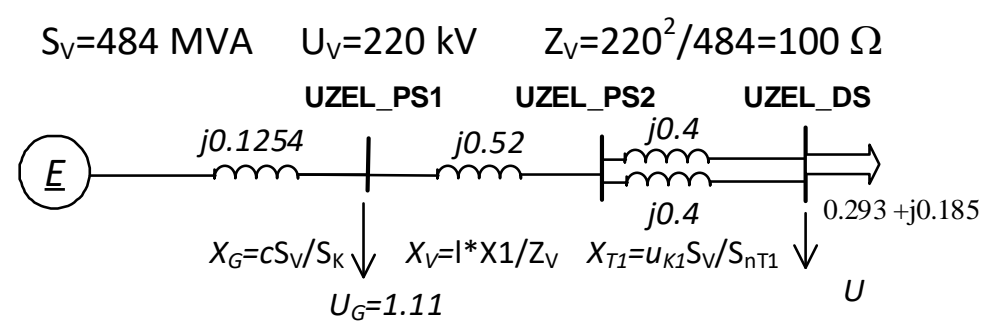

Obr. 5.2-3 Náhradní schéma v poměrných hodnotách

Celková reaktance $X$ je rovna 0.8454 . Spočteme napřed napětí $U$ v místě zátěže. Řešením rovnice (5.2-4), kde $E$ nahradíme napětím $U_{\mathrm{G}}$, za $X$ dosadíme jen reaktanci sítě $X_{\mathrm{S}}=0.72$ a za $Q_{\mathrm{S}}$ odběr zátěže $Q_{\mathrm{L}}=0.185$, obdržíme hodnotu 0.946 . Stejnou hodnotu získáme i z rovnosti $U=\mathrm{P}_{\mathrm{L}} / 150$. Nyní již pomocí napětového děliče zjistíme hodnotu $E=U_{\mathrm{G}}+X_{\mathrm{G}}\left(U_{\mathrm{G}}-U\right) / X_{\mathrm{S}}=1.14$.

Analytické řešení rovnic (5.2-1) a (5.2-4) neexistuje, takže se musí provést iteračně pro proměnnou $\xi$. Obr. 5.2-4 ukazuje řešení, kde pro $U=0.7$ mají obě křivky společný bod i tečny.

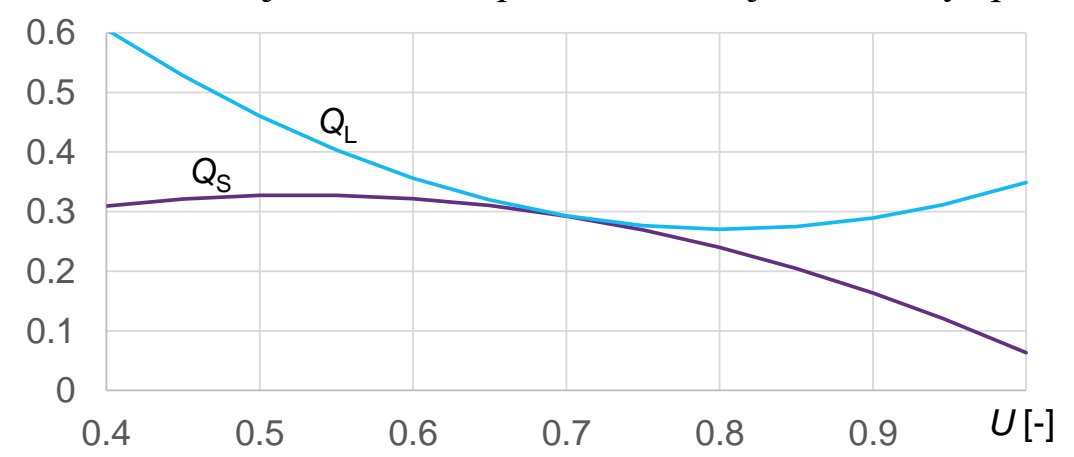

Obr. 5.2-4 Napět’ové závislosti jalového výkonu dodaného zdrojem $Q_{S}$ a odebraného zátěží $Q_{L}$

Navýšení $\xi$ vychází na 1.68. Tomu odpovídá odběr výkonu 176 MW a 142 Mvar. 
Nyní můžeme nasimulovat dosažení meze napět'ové stability i na dynamickém modelu. Výchozí chod sítě odpovídající modelu zdroje napájejícího jednu zátěž přes přenosovou sít' je připraven $v$ př́ípadu UST_STAV $v$ projektu NAP_STAB. V př́padu je již nadefinována v databázi dynamických modelů uzlů statická zátěž s typovými parametry podle Tab. 5.2-1.

Tab. 5.2-1 Typové parametry statické zátěže

\begin{tabular}{|l|l|l|l|l|l|l|l|l|l|}
\hline Stat char & $\mathrm{Ap}(-)$ & $\mathrm{Bp}(-)$ & $\mathrm{Cp}(-)$ & $\mathrm{A} 0(-)$ & $\mathrm{B} 0(-)$ & $\mathrm{C} 0(-)$ & Umin $(-)$ & - & Komentář \\
\hline INDUST & 1 & 0 & 0 & -9.8 & 4.9 & 0 & 0.6 & & Průmyslová zátěž \\
\hline
\end{tabular}

Pro jalový odběr jsou definovány parametry s indexem 0 . Vlastní koeficienty jalového odběru MODES modifikuje podle účiníku zátěže $\left(\mathrm{A}_{\mathrm{Q}}=\mathrm{A}_{0} / \operatorname{tg} \varphi \mathrm{B}_{\mathrm{Q}}=1+\mathrm{B}_{0} / \operatorname{tg} \varphi\right)$. Velikost parametrů $\mathrm{A}_{0}$ a $\mathrm{B}_{0}$ byla optimalizována, aby se blížila hodnotám ze zadání.

Pro zdroj EKV_PS není záznam v databázi dynamických modelů bloků, takže má přiřazeny standardní modely (CLAS pro generátor a STAN pro turbínu a buzení) a parametry.

Doba výpočtu se zadá $180 \mathrm{~s}$ (s krokem výpisu $1 \mathrm{~s}$ ), do scénáře se definuje v čase $\mathrm{t}=1 \mathrm{~s}$ rampová změna zatížení v uzlu UZEL_DS zásahem RAMP s parametry 50 a 25 (nárůst zatížení o $50 \%$ s trendem $25 \% / \mathrm{min}$ ). V grafice je již zadáno napětí a činný a jalový odběr zátěže.

Obr. 5.2-5 ukazuje průběh simulačního výpočtu.

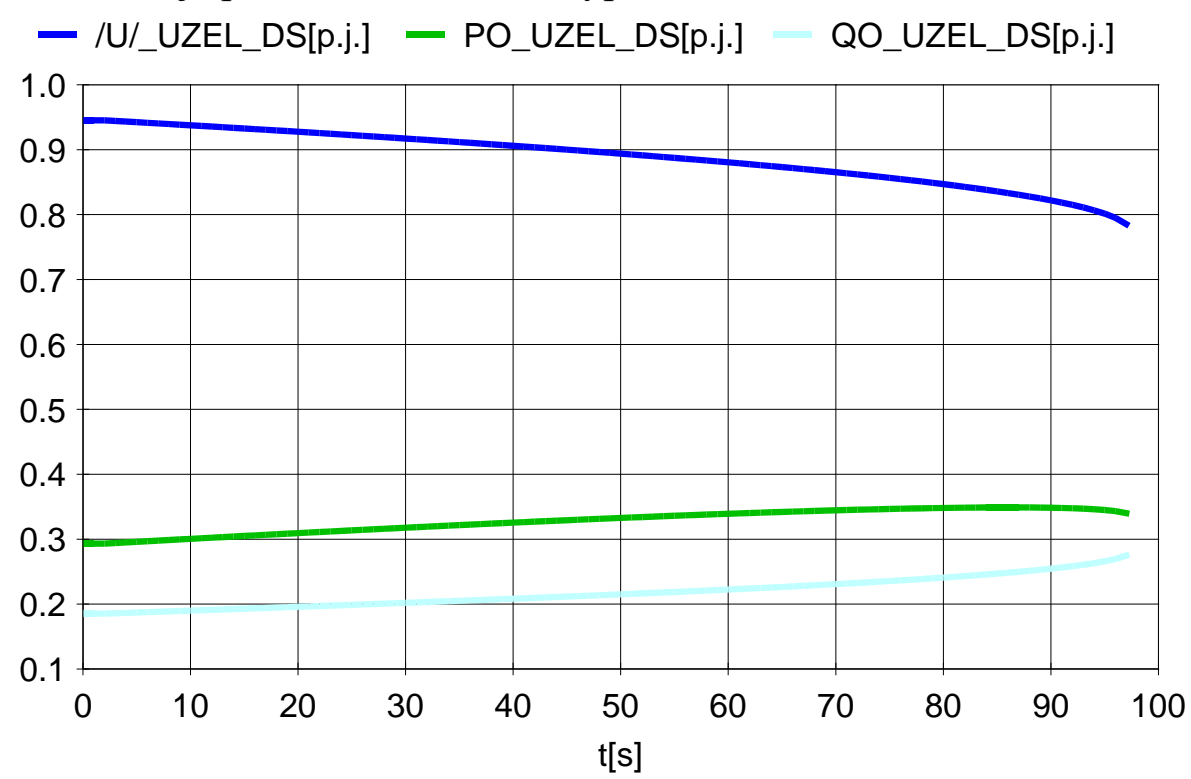

Obr. 5.2-5 Průběhy napětí a odběrů výkonu během zvyšování zátěže pro model generátoru CLAS

Výpočet je ukončen $\mathrm{v}$ čase $\mathrm{t}=97 \mathrm{~s}$ při napětí $U=0.785$, kdy MODES není schopen dodržet požadovanou přesnost výpočtu $1 \%$. Výkon odebíraný zátěží je 165 MW a 133 Mvar.

Obr. 5.2-6 ukazuje změnu napětí v závislosti na činném výkonu zátěže.

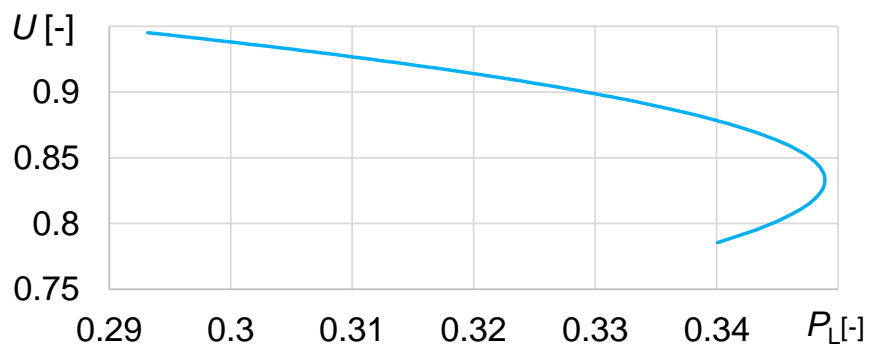

Obr. 5.2-6 Průběh závislosti napětí na přenášeném činném výkonu

Křivka má nosovitý charakter s výrazným maximem přenášeného činného výkonu. Po dosažení maxima je simulační výpočet automaticky ukončen pro nedodržení přesnosti iteračního procesu. To znamená, že algoritmus výpočtu není schopen nalézt řešení. 


\subsection{Napět’ový kolaps}

Dosud uvedené metody vyšetřování napět'ové stability byly založeny na vyšetření schopnosti soustavy přenášet výkon k zátěži a byly statické - čas tam nehrál roli. Ukážeme ještě dynamické aspekty napětové stability, kde hrají roli budicí systémy synchronních generátorů, závislost výkonů asynchronních motorů na napětí a přepínání odboček transformátorů.

\section{Př́klad 5-2}

Pro soustavu z Obr. 5.3-1 analyzujte napětovou stabilitu. Zjistěte časové průběhy napětí v uzlech č. 7, 10 a 11 při výpadku vedení V6_7-1. Při analýze uvažujte vlivy omezovače proudu v regulátoru buzení synchronních strojů, přepínání odboček transformátoru a různých typů zátěže. Zátěž v uzlu č. 11 je modelována z 50 \% konstantní admitancí a z 50 \% konstantním činným a jalovým proudem. Zátěž v uzlu č. 8 modelujte:

a) jako konstantní výkon (nezávislý na napětí) a

b) z $35 \%$ konstantním činným a jalovým proudem a z 65\% ekvivalentním asynchronním motorem.

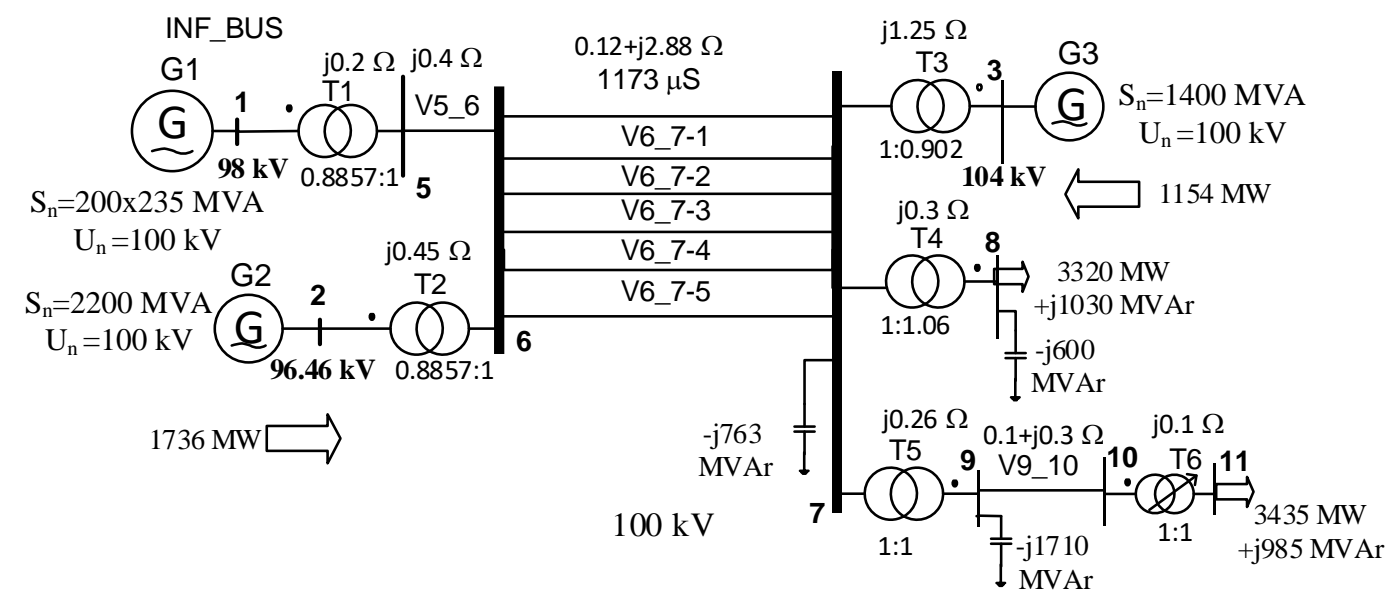

\section{Obr. 5.3-1 Model soustavy pro simulaci napětového kolapsu}

Př́ḱlad byl s úpravami převzat z knihy [21] („Example 14.2“ str. 979). Vzhledem ke způsobu zadávání parametrů chodu sítě v knize v poměrných hodnotách, bylo ponecháno napětí $100 \mathrm{kV}$ ve všech uzlech a ve schématu na Obr. 5.3-1 jsou parametry uvedeny v pojmenovaných hodnotách kromě převodu, který je definován poměrem napětí v počátečním uzlu (ve schématu značený tečkou) a koncovém uzlu ve stavu naprázdno.

\section{Řešení}

C̆asové průběhy napětí zjistíme simulačním výpočtem programem MODES. V případu UST_KUND v projektu NAP_STAB jsou připravena vstupní data chodu sítě (variace KUN11012.UST), dynamické modely modelů zátěže pro prríklad a) a dynamické modely bloků.

V databázi dynamických modelů uzlů UZLY.DTB jsou již nadefinovány dva záznamy:

\begin{tabular}{|c|c|c|c|c|c|c|c|c|c|c|c|c|c|c|c|c|c|c|c|}
\hline $\begin{array}{r}\text { Jmeno } \\
\text { Uzlu }\end{array}$ & & $\begin{array}{l}\mathrm{P} \\
\mathrm{I} \overline{0}\end{array}$ & $\stackrel{\mathrm{P}}{\mathrm{G}}$ & $\begin{array}{l}\mathrm{P} \\
\mathrm{T} \%\end{array}$ & $\begin{array}{l}Q \\
\mathrm{I} \text { 응 }\end{array}$ & $\frac{\mathrm{Q}}{\mathrm{B} \%}$ & $\stackrel{\mathrm{S}}{\mathrm{D} \%}$ & $\begin{array}{l}\mathrm{S} \\
\mathrm{S} \%\end{array}$ & $\begin{array}{l}\mathrm{S} \\
\mathrm{M} \%\end{array}$ & 1. & $\begin{array}{l}2 . \\
\text { FO }\end{array}$ & & 4 & $\begin{array}{c}\text { TypPar } \\
\text { Stat }\end{array}$ & $\begin{array}{r}\text { TypPar } \\
\text { Motor }\end{array}$ & $\begin{array}{l}\text { TypPar } \\
\text { FO }\end{array}$ & $\begin{array}{l}\text { TypPar } \\
\text { Ter }\end{array}$ & & $\begin{array}{c}\text { TypPar } \\
\text { Dyn }\end{array}$ \\
\hline ' NODE11 & ' & $5 \overline{0}$ & 50 & 0 & 50 & 50 & $\overline{0}$ & 0 & 0 & $\overline{0}$ & 0 & 0 & 0 & 1 & $T$ & $T$ & & ' ' & ' \\
\hline 'NODE8 & ' & 0 & 0 & 0 & 0 & 0 & 0 & 100 & 0 & 0 & 0 & 0 & 0 & 'KONSTS' ' & ' ' & ' ' & & ' ' & ' \\
\hline
\end{tabular}

Sada KONSTS je součástí lokálního katalogu typových parametrů sítě TYP_SIT.CAT:

Tab. 5.3-1 Typové parametry statické zátěže pro uzel NODE8

\begin{tabular}{|c|c|c|c|c|c|c|c|c|}
\hline Stat char & $\mathrm{Ap}(-)$ & $\mathrm{Bp}(-)$ & $\mathrm{Cp}(-)$ & $\mathrm{AO}(-)$ & $\mathrm{B} 0(-)$ & $\mathrm{CO}(-)$ & $\operatorname{Umin}(-)$ & - Komentár̆ \\
\hline KONSTS & 0 & 0 & 0 & 0 & -1 & 0 & 0.6 & Konstantní P a Q \\
\hline
\end{tabular}

Blok G1 je zadán v databázi dynamických modelů BLOK.DTB jako zdroj konstantního napětí modelem CONS. G2 a G3 jsou modelovány modelem PARK s parametry dle Tab. 5.3-2. 
Tab. 5.3-2 Typové parametry generátoru pro model PARK

\begin{tabular}{|l|l|l|l|l|l|l|l|l|l|l|l|l|l|l|l|}
\hline Generátory & $\begin{array}{l}\text { Un } \\
(\mathrm{kV})\end{array}$ & $\begin{array}{l}\text { Cosn } \\
(-)\end{array}$ & $\begin{array}{l}\text { Sng } \\
(\mathrm{MVA})\end{array}$ & $\begin{array}{l}\mathrm{Xd} \\
(-)\end{array}$ & $\begin{array}{l}\text { Xq } \\
(-)\end{array}$ & $\begin{array}{l}\text { Xd1 } \\
(-)\end{array}$ & $\begin{array}{l}\text { Xd2 } \\
(-)\end{array}$ & $\begin{array}{l}\text { Xt } \\
-\end{array}$ & $\begin{array}{l}\text { Td01 } \\
(\mathrm{s})\end{array}$ & $\begin{array}{l}\text { Td02 } \\
(\mathrm{s})\end{array}$ & $\begin{array}{l}\text { Tq02 } \\
(\mathrm{s})\end{array}$ & $\begin{array}{l}\text { Tm } \\
(\mathrm{s})\end{array}$ & $\begin{array}{l}\text { Xq1 } \\
(-)\end{array}$ & $\begin{array}{l}\text { Tq01 } \\
(\mathrm{s})\end{array}$ & $\begin{array}{l}\text { Komentáŕ } \\
(\text { text })\end{array}$ \\
\hline KUN142 & 100 & 0.85 & 400 & 2.07 & 1.99 & 0.28 & 0.215 & 0 & 4.1 & 0.033 & 0.062 & 9.2 & 0.49 & 0.56 & dle Kundur Ex.14.2 \\
\hline
\end{tabular}

Parametry byly převzaty z knihy [21] s výjimkou mechanické časové konstanty Tm, která byla zvětšena na obvyklou hodnotu.

Pro buzení byl zvolen rychlý tyristorový nezávislý budič (model AC_4) s proporcionálně integračním regulátorem. Blokové schéma je na Obr. 5.3-2 a parametry jsou v Tab. 5.3-3.

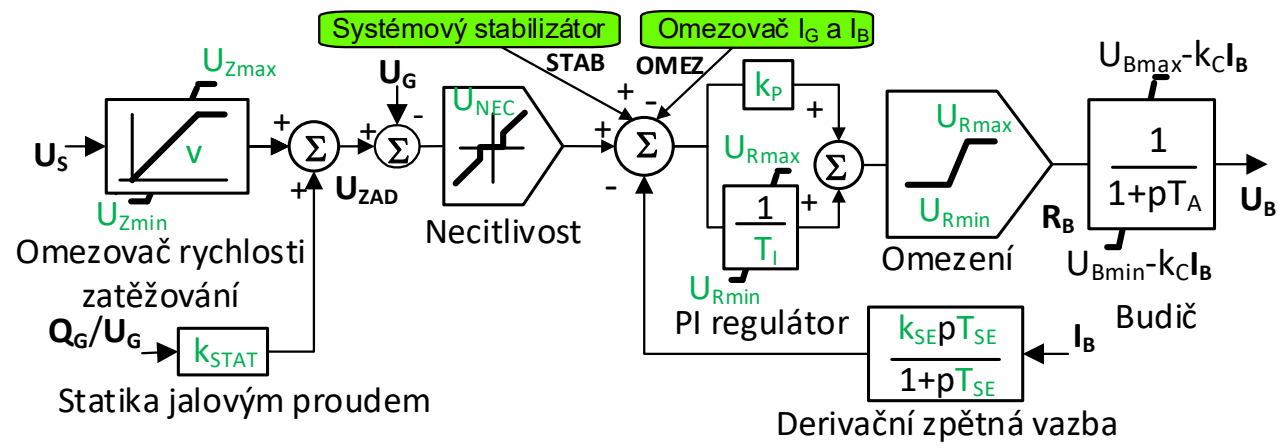

Obr. 5.3-2 Zjednodušené blokové schéma modelu buzení AC_4 s regulátorem buzení

Tab. 5.3-3 Typové parametry budiče a regulátoru buzení

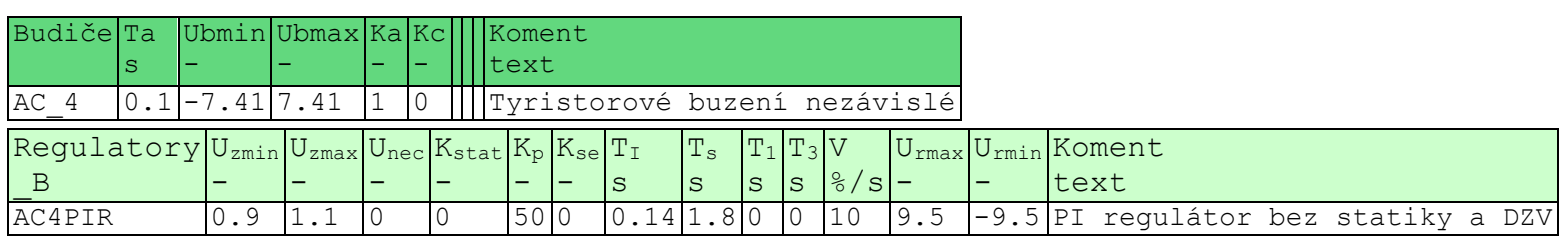

Na rozdíl od standardního modelu buzení STAN (viz Obr. 3.1-6) je možno zadat tzv. prŕ́davné automatiky regulátoru buzení, v našem případě omezovač statorového a rotorového proudu a systémový stabilizátor. Omezovač plní bezpečnostní funkci - chrání proti přetížení statorové a rotorové vinutí a systémový stabilizátor slouží k tlumení systémových kyvů - jsou zadány pouze pro blok G3. Schémata modelů jsou na Obr. 5.3-3 a jejich parametry v Tab. 5.3-4.
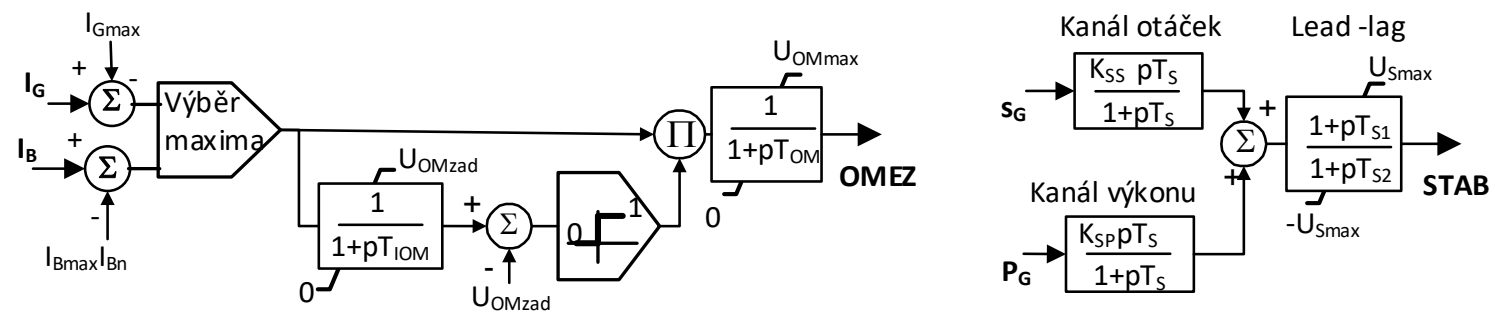

Obr. 5.3-3 Blokové schéma modelu omezovače proudů (vlevo) a systémového stabilizátoru (vpravo)

Tab. 5.3-4 Typové parametry omezovače rotorového proudu a systémového stabilizátoru

\begin{tabular}{|c|c|c|c|c|c|c|c|c|c|c|c|c|c|}
\hline $\begin{array}{l}\text { Automatiky } \\
\text { B }\end{array}$ & $\begin{array}{l}K_{S S} \\
-\end{array}$ & $\begin{array}{l}K_{\mathrm{SP}} \\
-\end{array}$ & $\begin{array}{l}\text { Ts } \\
\mathrm{S}\end{array}$ & $\begin{array}{l}\mathrm{T} \text { S1 } \\
\mathrm{S}\end{array}$ & $\begin{array}{l}\mathrm{T} \text { s2 } \\
\mathrm{S}\end{array}$ & $\begin{array}{l}U_{\text {smax }} \\
-\end{array}$ & $\begin{array}{l}\text { Uommax } \\
-\end{array}$ & $\begin{array}{l}\text { Uomzad } \\
-\end{array}$ & $\begin{array}{l}\text { Tiom } \\
\mathrm{S}\end{array}$ & $\begin{array}{l}\text { Tom } \\
S\end{array}$ & $\begin{array}{l}I_{\text {Bmax }} \\
-\end{array}$ & $\begin{array}{l}I_{\text {Gmax }} \\
-\end{array}$ & $\begin{array}{c}\text { Koment } \\
\text { (text) }\end{array}$ \\
\hline OM_PSS & 15 & -0.5 & 0.3 & 0 & 0 & 0.1 & 1 & 20 & 1 & 2 & 1.025 & 1.05 & !omezovač proudů a syst. stabilizátor \\
\hline
\end{tabular}

Model omezovače vyhodnocuje překročení dovolených hodnot $I_{B \max }$ a $I_{\text {Gmax. }}$ Překročí-li jeden z proudů tyto hodnoty, začne se překročení integrovat. Po překročení mezní hodnoty UOMzad se se zpožděním TOM objeví kladná hodnota proměnné OMEZ, která se odečte od regulační odchylky regulátoru napětí a blok se odbudí.

Systémový stabilizátor má na vstupu dvě proměnné: skluz $\mathrm{S}_{\mathrm{G}}$ a činný výkon $\mathrm{P}_{\mathrm{G}}$ generátoru. Po zesílení a odfiltrování stejnosměrné složky, jsou výstupy obou kanálů sečteny a po úpravě fázového posunu a omezení je výsledný signál přičten k regulační odchylce regulátoru napětí. 
Transformátor T 6 má přepínání odboček, kterým se reguluje napětí v regulovaném uzlu. Přepínání odboček se zadává v datech větví v úseku regulačních traf, jak ukazuje výpis vstupního souboru KU11N_2.VET:

\begin{tabular}{|c|c|c|c|c|c|c|c|c|c|}
\hline $\begin{array}{l}\text { Porad } \\
\text { cislo }\end{array}$ & $\begin{array}{l}\text { CisPoc } \\
\text { uzlu }\end{array}$ & $\begin{array}{l}\text { Ciskon } \\
\text { uzlu }\end{array}$ & $\begin{array}{l}\text { Regulovaný } \\
\text { uzel }\end{array}$ & $\begin{array}{c}\text { Ptmin } \\
(-)\end{array}$ & $\begin{array}{c}\text { Ptmax } \\
(-)\end{array}$ & $\begin{array}{l}\text { Krok } \\
(-)\end{array}$ & $\begin{array}{ll}\text { Uzad } & \text { necU } \\
(\%) & (\%)\end{array}$ & $\begin{array}{l}\text { Stav } \\
(0 / 1)\end{array}$ & \\
\hline 1 & 10 & 11 & $\overline{\prime N} \circ \overline{\mathrm{DE} 11}$ ' & 0.9 & 1.1 & $\overline{0.01}$ & 100 & 1 & \\
\hline
\end{tabular}

Dynamický model vlastního regulátoru (nazývaného také hladinovým regulátorem trafa) je na následujícím obrázku.

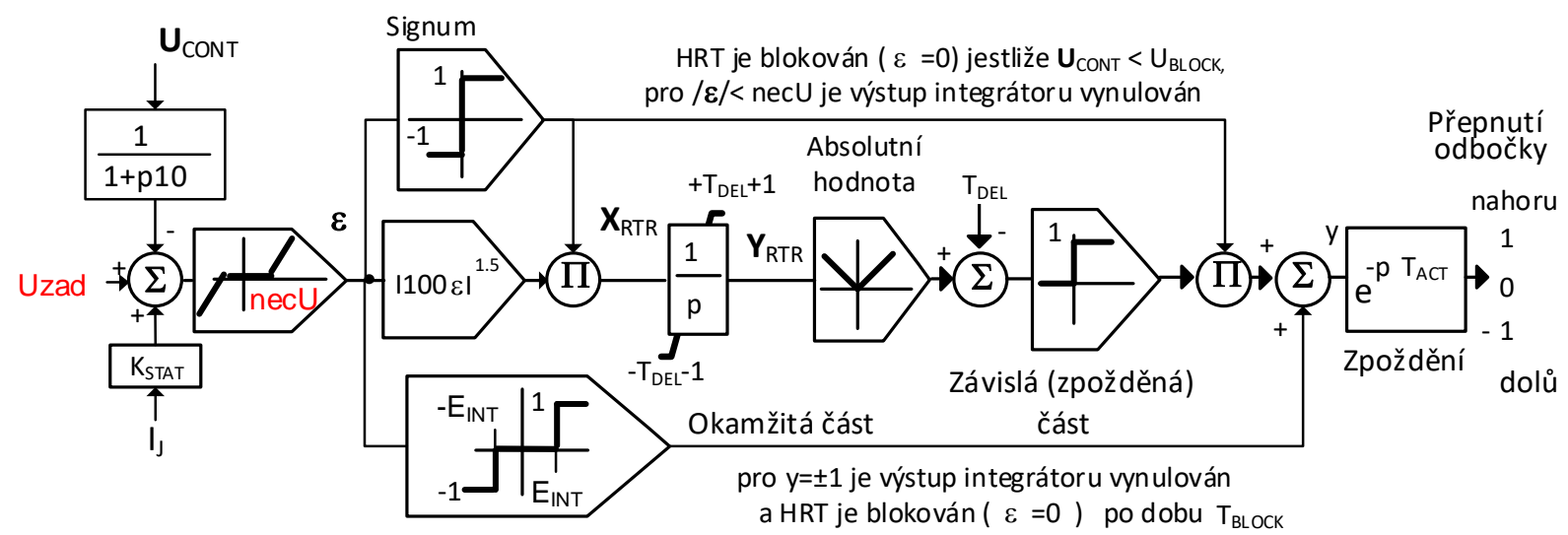

Obr. 5.3-4 Zjednodušené blokové schéma modelu hladinového regulátoru trafa (HRT)

Jestliže regulované napětí U UONT vybočí od zadané hodnoty Uzad o necitlivost necU, dojde k přepnutí odbočky se zpožděním daným součtem doby $\mathrm{T}_{\mathrm{ACT}}$ (modelující zpoždění vlastního přepnutí) a doby T vyplývající z charakteristiky HRTu.

Charakteristika je určena mocninnou funkcí v závislosti na parametrech $\mathrm{T}_{\mathrm{DEL}}$ a Exp. $\mathrm{V}$ př́ípadě, že je konstantní $\varepsilon$, pak $\mathrm{T}=\mathrm{T}_{\mathrm{DEL}} / 100 \varepsilon /^{1.5}$. V př́padě, že odchylka je větší než zadaná hodnota $E_{I N T}$, dojde $\mathrm{k}$ povelu na přepnutí okamžitě. Po přepnutí je činnost regulátoru blokována po dobu $\mathrm{T}_{\mathrm{BLOCK}}$, která zajistí jednak odeznění přechodných dějů a jednak opětnou pohotovost

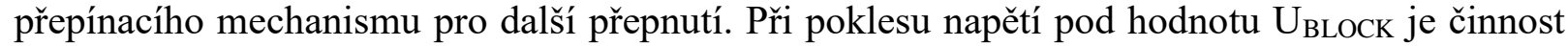
regulace opět zablokována, tak aby nezhoršovala provozní stavy při deficitu jalového výkonu a odblokuje se až po zotavení napětí nad hodnotu UUNBLOcK.

Typové parametry modelu HRTu jsou definovány záznamem v databázi dynamických modelů sítě SIT.DTB:

\begin{tabular}{l} 
porad. nazev Typ Model \\
cislo uzlu Reg.trafa \\
\hline 1 'NoDE11' 'HRTKUN' 1
\end{tabular}

Sada HRTKUn je definována v lokálním katalogu typových parametrů sítě TYP_SIT.CAT:

n\# Reg_traf $U_{\text {BLOCK }} U_{\text {UNBLOCK }} K_{\text {STAT }} E_{\text {INT }} \mathrm{T}_{\mathrm{DEL}} \mathrm{T}_{\mathrm{ACT}} \mathrm{T}_{\text {BLOCK }}$ Koment

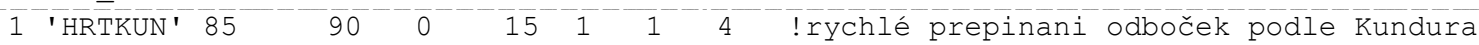

Nyní zbývá jen upravit parametry výpočtu. Do scénáře se zadá v čase $\mathrm{t}=1 \mathrm{~s}$ vypnutí vedení V6_7-1 zásahem BRAN s parametrem 0. Do prvního grafu v grafice se zadají v souladu se zadáním příkladu napětí /U/v uzlech NODE7, NODE10 a NODE11. Do dalších grafư můžeme vybrat odběry výkonu PO a QO v uzlu NODE8, proměnné UGEN, QG, IBUD (poměrné budící napětí vztažené na jmenovitý budicí proud $\mathrm{I}_{\mathrm{Bn}}$ ) a IGEN bloku G3 a nakonec do čtvrtého grafu např́iklad poměrné budicí napětí UB a proud IB (vztažené na jmenovité hodnoty naprázdno) bloku G3.

Následující obrázky ukazují výsledky simulačního výpočtu pro př́́pad a). 

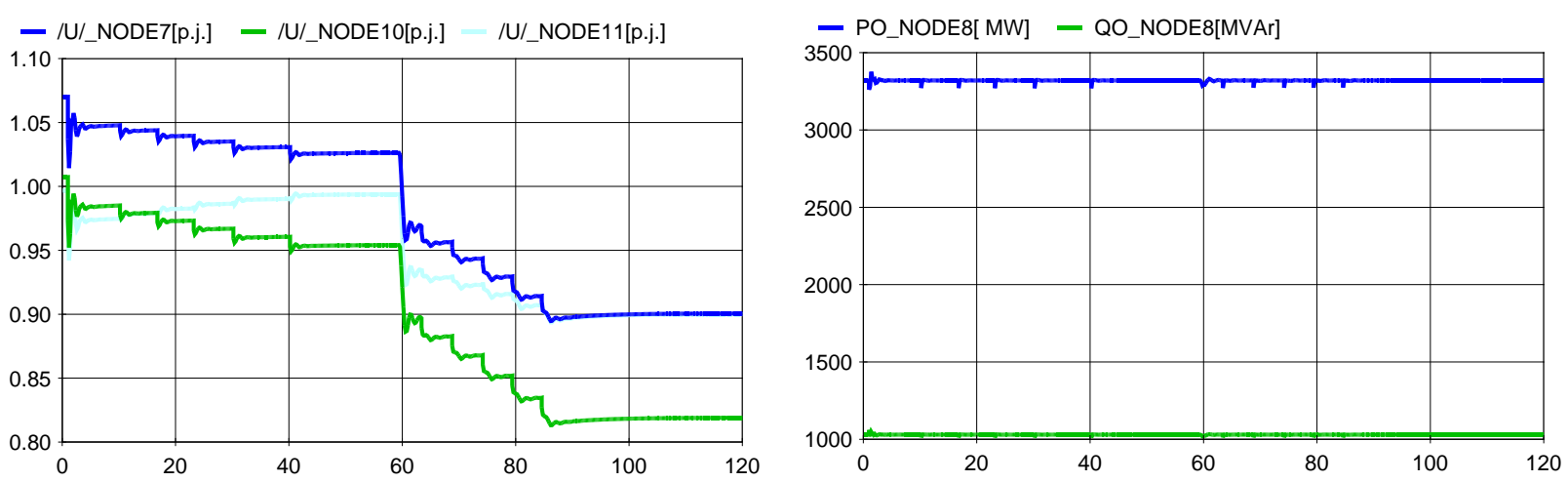

Obr. 5.3-5 Průběhy napětí a odebíraných výkonů pro konstantní odběr výkonu v uzlu NODE8

Po výpadku vedení je vidět pokles napětí ve všech uzlech. HRT na trafu T6 přepíná odbočky tak, aby vyreguloval napětí v uzlu NODE11 na zadanou hodnotu $100 \%$. To však způsobuje pokles napětí v uzlech NODE10 a NODE7 .

Blok G3 se snaží udržet své svorkové napětí UGEN dodávkou jalového výkonu QGEN do sítě. To však způsobí přetěžování statoru i rotoru (proudy IGEN a IBUD jsou větší než je jmenovitá hodnota $100 \%$ ). Na to zareaguje omezovač proudů a $\mathrm{v}$ čase $\mathrm{t}=59.45 \mathrm{~s}$ odbudí generátor. To způsobí znovu pokles napětí ve všech uzlech a přepínání odboček trafa T6 situaci ještě zhoršuje. Blok G3 již není schopen dodat více jalového výkonu pro návrat napětí k jmenovitým hodnotám a také je přetížen. Soustava sice dosáhla rovnovážného stavu a dokonce je schopna napájet zátěž v uzlu NODE8, ale veličiny nejsou v dovolených mezích, takže podle definice v Úvodu soustava není stabilní.
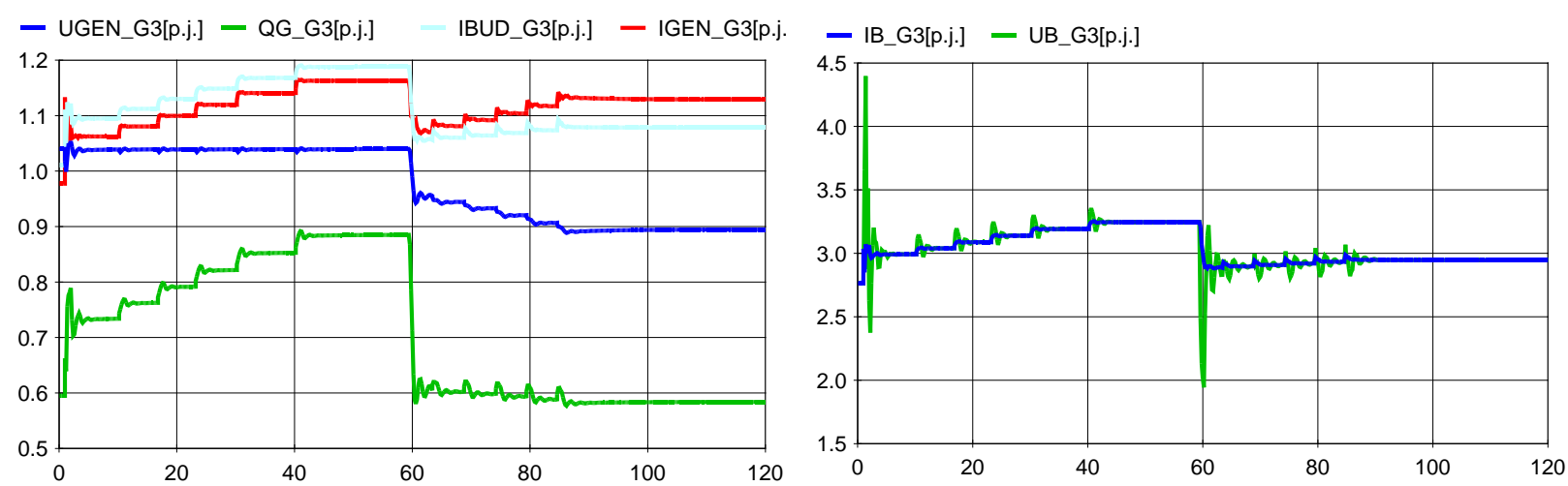

Obr. 5.3-6 Průběhy veličin bloku G3 pro konstantní odběr výkonu v uzlu NODE8

Pro př́ípad b) musíme změnit model zátěže v uzlu NODE3. Provede se to postupem známým již z Př́́kladu 4.6. Tlačítkem @ spustíme Editor databázi dynamických modelů uzlů. Ze seznamu uzlů vybereme NODE8 a stiskneme tlačítko Ekvivalentní asynchronní motor. Z tabulky vybereme sadu typových parametrů ASMVEN a stiskneme tlačítko Vyměnit parametry. Nakonec zadáme objemy pro konstantní činný a jalový proud po $35 \%$ a zbytek $65 \%$ pro Ekvivalentní asynchronní motor pomocí jezdců vpravo s potvrzením tlačítkem Změnit podíly. Počet aktivních záznamů v modifikované databázi zadáme 1 a tlačítkem OK změny uložíme s potvrzením vzniku nové modifikace.

Záznam v modifikované databázi dynamických modelů uzlů UZLY.001 bude následující:

\begin{tabular}{|c|c|c|c|c|c|c|c|c|c|c|c|c|c|c|c|c|}
\hline $\begin{array}{r}\text { Jmeno } \\
\text { Uzlu }\end{array}$ & $\begin{array}{l}\mathrm{P} \\
\mathrm{I} \%\end{array}$ & $\begin{array}{ll}\mathrm{P} & \mathrm{P} \\
\mathrm{G} \frac{\mathrm{o}}{\mathrm{O}} & \mathrm{T}\end{array}$ & $\begin{array}{ll}P & Q \\
T & \\
T & \end{array}$ & 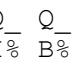 & $\frac{\mathrm{S}}{\mathrm{D} \frac{\overline{0}}{0}}$ & $\frac{S}{S \frac{0}{0}}$ & $\stackrel{\mathrm{S}}{\mathrm{M} \div \overline{\mathrm{o}}}$ & & $\begin{array}{l}2.3 \\
\mathrm{FO} \%\end{array}$ & & 4. & $\begin{array}{c}\text { TypPar } \\
\text { Stat }\end{array}$ & $\begin{array}{r}\text { TypPar } \\
\text { Motor }\end{array}$ & $\begin{array}{c}\text { TypPar } \\
\text { FO }\end{array}$ & $\begin{array}{c}\text { TypPar } \\
\text { Ter }\end{array}$ & $\begin{array}{c}\text { TypPar } \\
\text { Dyn }\end{array}$ \\
\hline 'NODE8 & 35 & 00 & 35 & 350 & 0 & 0 & 65 & 0 & 0 & 0 & 0 & . & 'ASMVEN' & & 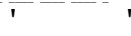 & ' \\
\hline
\end{tabular}

Sada ASMVEN je součástí lokálního katalogu typových parametrů sítě TYP_SIT.CAT:

Tab. 5.3-5 Typové parametry modelu ekvivalentního asynchronního motoru

\begin{tabular}{|l|l|l|l|l|l|l|l|l||l|}
\hline Ekv_motor & $\operatorname{Am}(-)$ & $\mathrm{Bm}(-)$ & $\mathrm{Tm}(\mathrm{s})$ & $\mathrm{R} 1(-)$ & $\mathrm{X} 1(-)$ & $\mathrm{Xmi}(-)$ & $\mathrm{R} 2(-)$ & $\mathrm{X} 2(-)$ & Koment \\
\hline ASMVEN & 0 & 1 & 2 & 0.016 & 0.07 & 2.95 & 0.0226 & 0.368 & Pohony s ventilátory \\
\hline
\end{tabular}


Parametry Am a Bm definují momentovou charakteristiku poháněného zařízení a pro $\mathrm{Bm}=1$ se bude jednat o kvadratickou závislost na otáčkách, kterou mají ventilátory. Náhradní schéma ekvivalentního asynchronního motoru je zobrazeno na následujícím obrázku:
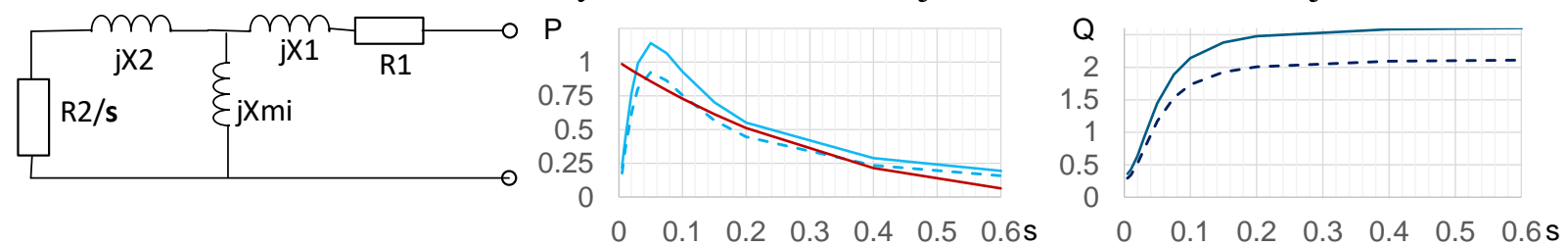

Obr. 5.3-7 Náhradní schéma modelu asynchronního motoru (vlevo) a závislost výkonu na skluzu a napětí

Výsledky simulačního výpočtu jsou na následujících obrázcích.
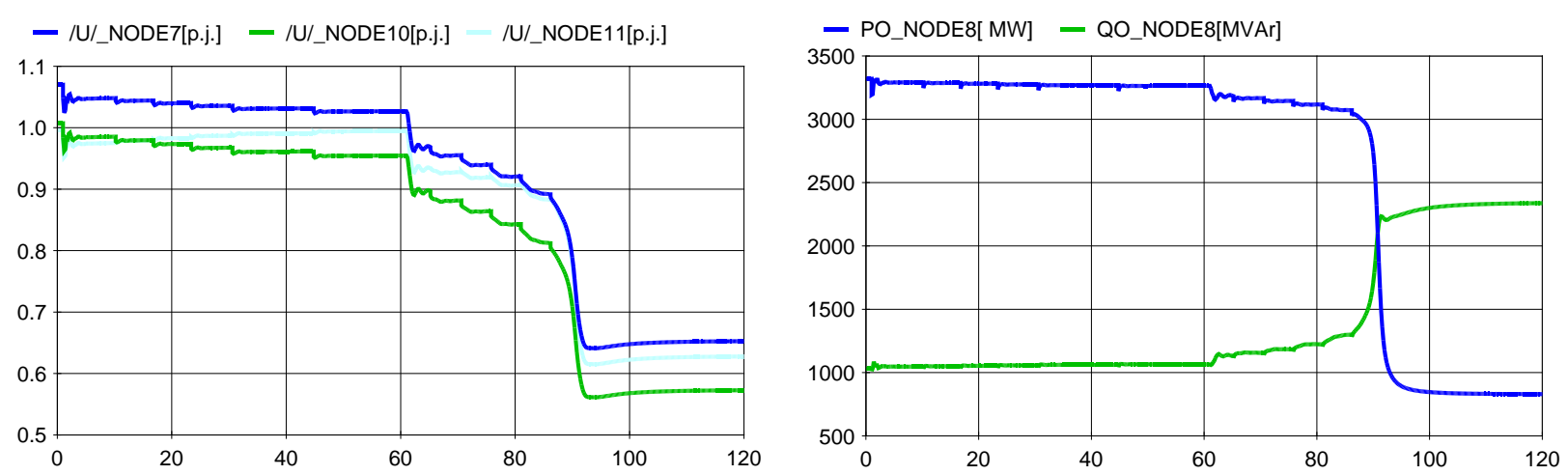

Obr. 5.3-8 Průběhy napětí a odebíraných výkonů pro ekvivalentní asynchronní motor v uzlu NODE8

Po výpadku vedení je průběh přechodného děje podobný jako v př́ípadě a) s mírnějšími poklesy ( $35 \%$ zátěže v uzlu NODE 8 pomáhá napětí stabilizovat), ale jakmile zapůsobí v čase $\mathrm{t}=61 \mathrm{~s}$ omezovač proudů, dojde po posledním přepnutí odbočky trafa $\mathrm{T} 6$ k prudkému pádu napětí, jak je vidět na Obr. 5.3-8 vlevo. Př́činou je chování ekvivalentního asynchronního motoru, který na pokles napětí reaguje nárůstem odběru jalového výkonu, jak je vidět na grafu vpravo. Příčinou tohoto jevu je tzv. lavina napětí, která se dá vysvětlit ze závislostí činného a jalového výkonu motoru na skluzu a napětí zobrazených na Obr. 5.3-7 vpravo. Plnou čarou jsou kresleny závislosti při jmenovitém napětí $u=1$ a čárkované při sníženém napětí $u=0.9$. Skluz motoru je určen průsečíkem činného výkonu $P$ s charakteristikou zátěže. Při poklesu napětí na 0.9 se skluz zvětší z 2.5 na přibližně 4 \%. Jalový výkon se zvětší asi o polovinu. To způsobí v síti další pokles napětí a další zvětšení skluzu a jalového výkonu. Vlivem této kladné zpětné vazby se motor zastaví a odebírá velký jalový výkon, jak ukazuje Obr. 5.3-8 vpravo v t = $90 \mathrm{~s}$.

Napětí generátoru G3 klesá $\mathrm{k} 60 \%$ při proudovém přetížení $140 \%$ a v reálu by bylo jen otázkou času, kdy by ochrany blok vypnuly. Vzhledem k tomu, že veličiny nejsou v dovolených mezích, je i tento př́pad nestabilní, navíc bez schopnosti napájet motorickou zátěž.
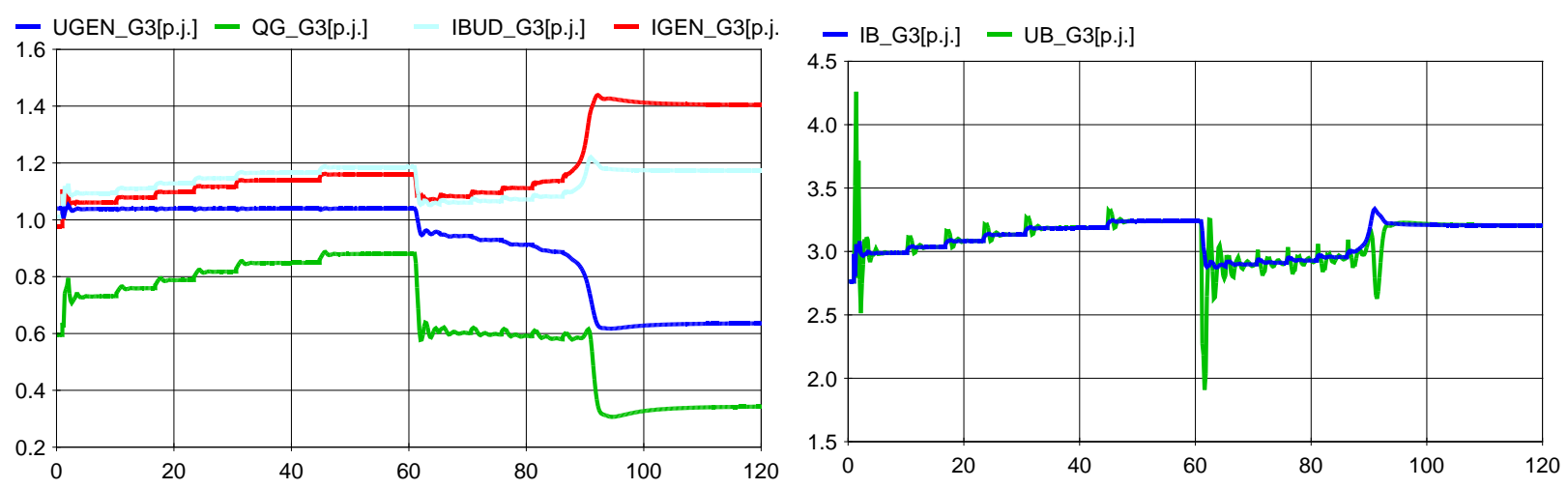

Obr. 5.3-9 Průběhy veličin bloku G3 pro ekvivalentní asynchronní motor v uzlu NODE8

Pokud by se HRT zablokoval již při poklesu napětí na $95 \%$, k lavině napětí by nedošlo. 


\section{Př́́klady narušení stability ES}

V tomto století došlo k řadě velkých systémových poruch spojených se ztrátou stability a vedoucích $\mathrm{k}$ ztrátě napájení odběratelů bud' úplné (systémový blackout) nebo částečné (působením frekvenčního odlehčování byla řízeně vypnuta část odběratelů). Seznam ukazuje některé z nich (v závorce jsou zprávy provozovatelů soustav nebo zodpovědných orgánů):

1. 14. 8. 2003 - blackout v USA a Kanadě ([39])

2. 23. 9. 2003 - blackout v Dánsku a Švédsku ([40])

3. 28. 9. 2003 - blackout Itálie ([41])

4. 12. 7. 2004 - blackout v Řecku ([42][52])

5. 4. 11.2006 - rozpad synchronního propojení UCTE na tři ostrovy ([43])

6. 8. 9. 2011 - blackout na západě USA a východě Mexika ([44])

7. 31.3.2015 - blackout Turecka ([45])

8. 28. 9. 2016 - blackout Jižní Austrálie ([46])

9. 9. 8. 2019 - frekvenční odlehčování v Anglii. ([47]).

V češtině jsou systémové poruchy popsány v knize [4] a článcích [48] a [49]. Podrobný rozbor dějů včetně simulačních výpočtů rozpadu UCTE a blackoutu Turecka je proveden v příspěvcích [50] a [51]. Příčiny a následky uvedených poruch shrnuje přehled:

\begin{tabular}{|c|c|c|c|c|}
\hline Porucha & $\begin{array}{l}\text { Iniciační } \\
\text { porucha }\end{array}$ & Příčina & Následek & Pozn. \\
\hline $\begin{array}{l}\text { USA a } \\
\text { Kanada } \\
\text { 14. 8. } 2003\end{array}$ & Výpadek vedení & $\begin{array}{l}\text { Přetížení vedení } \\
\text { kontakt s vegetací }\end{array}$ & $\begin{array}{l}\text { Ztráta úhlové stability } \\
\text { Kaskáda výpadků vedení } \\
\text { Ztráta frekvenční stability }\end{array}$ & $\begin{array}{l}\text { Částečný } \\
\text { blackout }\end{array}$ \\
\hline $\begin{array}{l}\text { Dánsko } \\
\text { Švédsko } \\
\text { 23.9. } 2003\end{array}$ & $\begin{array}{l}\text { Výpadek } \\
\text { rozvodny }\end{array}$ & Technická závada & $\begin{array}{l}\text { Ztráta úhlové stability } \\
\text { Kaskáda výpadků vedení } \\
\text { Ztráta frekvenční stability }\end{array}$ & $\begin{array}{l}\text { Částečný } \\
\text { blackout }\end{array}$ \\
\hline $\begin{array}{l}\text { Itálie } \\
\text { 28.9. } 2003\end{array}$ & Výpadek vedení & $\begin{array}{l}\text { Přetížení vedení, } \\
\text { kontakt s vegetací }\end{array}$ & $\begin{array}{l}\text { Ztráta úhlové stability } \\
\text { Kaskáda výpadků vedení } \\
\text { Ztráta frekvenční stability }\end{array}$ & Úplný blackout \\
\hline $\begin{array}{l}\text { Řecko } \\
\text { 12. } 7.2004\end{array}$ & Výpadek bloku & Technická závada & $\begin{array}{l}\text { Ztráta úhlové stability } \\
\text { Kaskáda výpadků vedení } \\
\text { Ztráta frekvenční stability }\end{array}$ & $\begin{array}{l}\text { Částečný } \\
\text { blackout }\end{array}$ \\
\hline $\begin{array}{l}\text { Rozpad } \\
\text { UCTE } \\
\text { 4. } 11.2006\end{array}$ & $\begin{array}{l}\text { Rozpojení } \\
\text { spínače } \\
\text { př́pojnic }\end{array}$ & $\begin{array}{l}\text { Neproveden } \\
\text { kontrolní výpočet } \\
\text { důsledků }\end{array}$ & $\begin{array}{l}\text { Ztráta úhlové stability } \\
\text { Kaskáda výpadků vedení } \\
\text { Rozdělení synchron. propojení }\end{array}$ & $\begin{array}{l}\text { Působení } \\
\text { frekvenčního } \\
\text { odlehčování }\end{array}$ \\
\hline $\begin{array}{l}\text { USA a } \\
\text { Mexiko } \\
\text { 8.9. } 2011\end{array}$ & $\begin{array}{l}\text { Vypínání } \\
\text { odpojovačem } \\
\text { Výpadek vedení }\end{array}$ & Chyba obsluhy & $\begin{array}{l}\text { Ztráta úhlové stability } \\
\text { Kaskáda výpadků vedení } \\
\text { Ztráta frekvenční stability }\end{array}$ & $\begin{array}{l}\text { Částečný } \\
\text { blackout }\end{array}$ \\
\hline $\begin{array}{l}\text { Turecko } \\
\text { 31. 3. } 2015\end{array}$ & Výpadek vedení & $\begin{array}{l}\text { Vysoké přetoky, } \\
\text { chybné nastavení } \\
\text { ochrany }\end{array}$ & $\begin{array}{l}\text { Ztráta úhlové stability } \\
\text { Kaskáda výpadků vedení } \\
\text { Ztráta frekvenční stability }\end{array}$ & Úplný blackout \\
\hline $\begin{array}{l}\text { Austrálie } \\
\text { 28.9.2016 }\end{array}$ & $\begin{array}{l}\text { Výpadky vedení } \\
\text { zásahem blesku }\end{array}$ & $\begin{array}{l}\text { Výpadky VtE při } \\
\text { zkratech }\end{array}$ & $\begin{array}{l}\text { Ztráta úhlové stability } \\
\text { Ztráta frekvenční stability }\end{array}$ & Úplný blackout \\
\hline $\begin{array}{l}\text { Anglie } \\
9.8 .2019\end{array}$ & $\begin{array}{l}\text { Výpadek vedení } \\
\text { zásahem blesku }\end{array}$ & $\begin{array}{l}\text { Výpadky VtE a } \\
\text { bloků PPC }\end{array}$ & Pokles frekvence & $\begin{array}{l}\text { Působení frekv. } \\
\text { odlehčování }\end{array}$ \\
\hline
\end{tabular}

V tomto skriptu se zaměříme na popis úplného a částečného blackoutu v Itálii a Řecku a poruchu v Anglii. Pomocí simulačních výpočtů objasníme mechanismus jejich vzniku. 


\section{1 Úplný blackout Itálie v r. 2003}

Následující popis je převzat z knihy [4]. V neděli 28. 9. 2003 v noci kolem 3:00 měla Itálie zatížení přibližně $24 \mathrm{GW}$ (z toho 3638 MW na čerpání v přečerpacích vodních elektrárnách). Celkově Itálie dovážela 6651 MW. Toky výkonu v MW byly 3610 ze Švýcarska, 2212 z Francie, 638 z Rakouska a 191 ze Slovinska.

Podrobná zpráva vyšetřovací komise [41] uvádí tento popis událostí. První část poruchového děje byla iniciována kaskádovitým vypínáním vedení, způsobeným přetěžováním vedení, zvětšováním průhybu lan vlivem většího oteplení procházejícím proudem a $\mathrm{s}$ tím narůstajícím rizikem přeskoků a zkratů na stromy pod vedením. První výpadek nastal v 03:01:42 na vedení 380 kV Lavorgo - Mettlen ve Švýcarsku. Vlivem vysokého zatížení (86 \% z tepelné kapacity 2400 A při teplotě $10^{\circ} \mathrm{C}$ ), větru a vysoké vlhkosti došlo k jednofázovému zkratu $\mathrm{s}$ neúspěšným opětným zapínáním. Opětné zapnutí vedení bylo také neúspěšné z důvodu velkého fázového rozdílu napětí na koncích vedení $\left(42^{\circ}\right)$. Tento velký fázový rozdíl byl způsoben velkými toky výkonu přes výpadkem oslabenou sít'. Zapnutí vedení s tak velkým úhlem by mohlo ohrozit rázy výkonu blízké generátory a způsobit další výpadky. Po tomto výpadku žádal švýcarský provozovatel sítě ETRANS italského GRTN snížit import o $300 \mathrm{MW}$, což bylo během 10 minut provedeno. Druhý výpadek nastal po přeskoku na strom v 03:25:21 na vedení $380 \mathrm{kV}$ Sils - Soazza ve Švýcarsku, které bylo přetíženo na 110 \%. Provoz takto přetíženého vedení je možný po omezenou dobu kolem 15 minut, aniž by byl překročen dovolený průhyb. Další výpadky následovaly krátce po sobě:

- 3:25:25 vedení $220 \mathrm{kV}$ Airolo - Mettlen ve Švýcarsku

- 3:25:28 vedení 220 kV Riddes - Avise a Riddes - Vallpelline (Švýcarsko - Itálie)

- 03:25:33 vedení $220 \mathrm{kV}$ Lienz - Soverzene (Rakousko - Itálie) a Menton - Camporosso (Francie - Itálie)

- 03:25:34 dvojité vedení 400 kV Albertville-Rondisone

- 03:25:35 vedení 400 kV Divaca- Redipuglia (Itálie - Slovinsko.

Poté se Itálie oddělila od synchronní zóny UCTE a začal ostrovní provoz - viz Obr. 6.1-1.

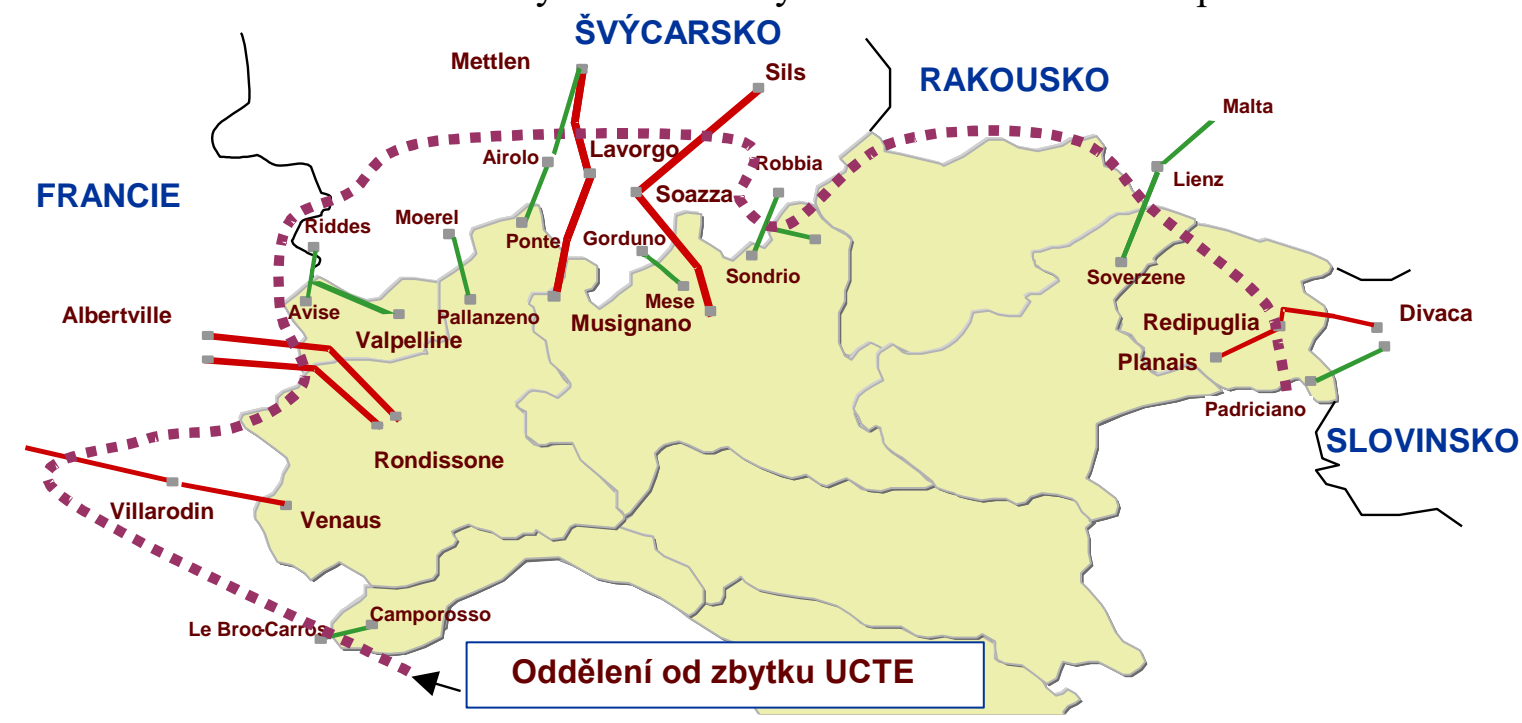

Obr. 6.1-1 Schéma oddělení Itálie od 1. synchronní zóny UCTE

V ostrově se automaticky odpojily přečerpací vodní elektrárny v čerpání (kolem 3200 MW před dosažením frekvence $49 \mathrm{~Hz}$ ). Dále působilo frekvenční odlehčování (asi 12 stupňů, odstupňovaných po $0.1 \mathrm{~Hz}$, s odlehčením kolem $600 \mathrm{MW}$ každý, sumárně $7700 \mathrm{MW}$ ). To však na udržení výkonové rovnováhy nestačilo, protože současně se odpojovaly zdroje v distribuční soustavě (kolem $3400 \mathrm{MW}$ před dosažením mezní frekvence $49 \mathrm{~Hz}$ ) a další zdroje větších výkonů (kolem 4100 MW). Frekvence klesala, až po 2.5 minutách došlo k úplnému blackoutu. 


\section{Př́klad 6-1}

V programu MODES analyzujte dynamické chování modelu synchronního propojení při ztrátě úhlové a frekvenční stability na prŕíkladu blackoutu Itálie z r. 2003.

\section{Řešení}

V projektu POR_STAB je připraven případ BIT2003F, který obsahuje všechna potřebná data pro simulační výpočet. Jedná se o:

1. výchozí ustálený chod sítě,

2. dynamické modely zdrojů,

3. automatiky modelující distanční a frekvenční ochrany a

4. scénář poruch a výběr proměnných do grafiky a výstupních souborů.

Obr. 6.1-2 ukazuje jednopólové schéma modelu sítě, kde původní kompletní model synchronního propojení byl zredukován na dva ekvivalentní uzly UCTE a ITALY propojené přes hraniční uzly hraničními vedeními mezi Itálií, Francií, Švýcarskem, Rakouskem a Slovinskem. Ekvivalentní a hraniční uzly jsou propojeny ekvivalentními větvemi, jejichž reaktance zohledňuje elektrickou vzdálenost uzlů. Hraniční uzly jsou propojeny větvemi s impedancemi odpovídajícími reálným hodnotám.

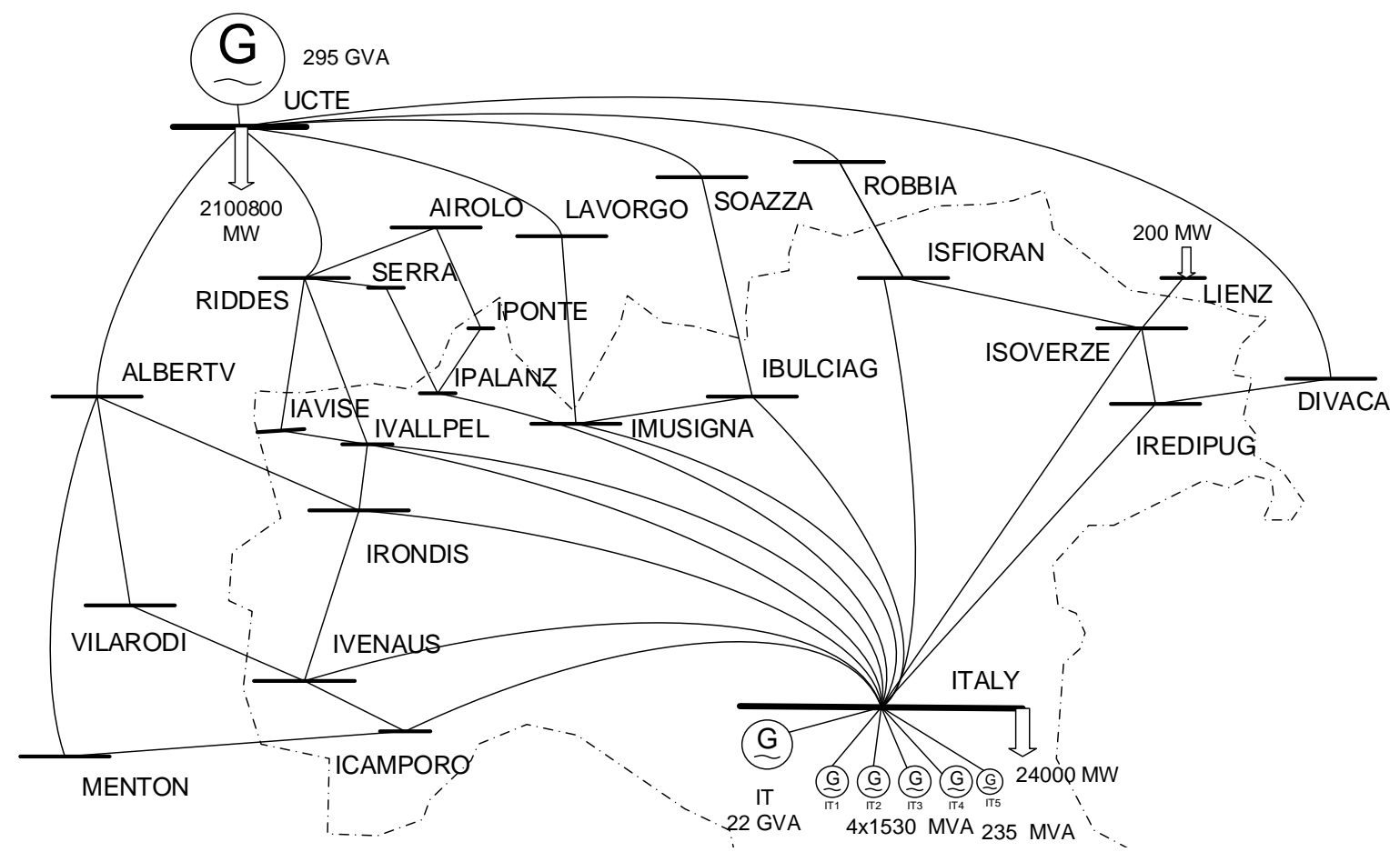

Obr. 6.1-2 Schéma zjednodušeného modelu pro simulační výpočet oddělení Itálie od synchronní zóny UCTE

Pro regulace frekvence ve vniklém ostrově hraje klíčovou roli ekvivalentní blok IT připojený do uzlu ITALY. Pro turbínu byl zvolen zjednodušený model parní turbíny STAN (viz Obr. 4.2-1) s parametry podle následujících tabulek:

Tab. 6.1-1 Typové parametry parní turbíny s malým zpožděním v přehříváku

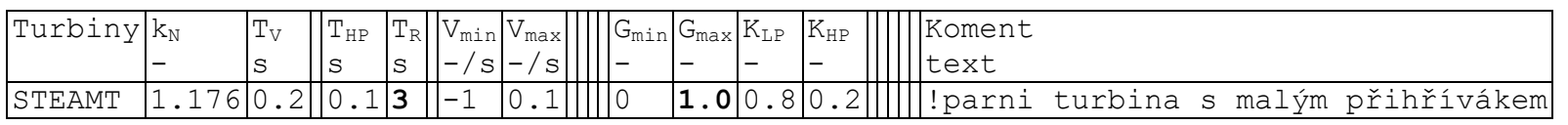

Tab. 6.1-2 Typové parametry regulátoru turbíny se statikou 5 a nenulovým zesílením kcor

\begin{tabular}{|l|l|l|l|l|l|l|l|l|l|l|l|l|l||l|l|l|}
\hline $\begin{array}{l}\text { Regulatory } \\
\mathrm{T}\end{array}$ & $\mathrm{A} 1$ & $\mathrm{~A} 2$ & $\mathrm{~T}_{\mathrm{IT}}$ & $\mathrm{T}_{\mathrm{N}}$ & $\mathrm{T}_{\mathrm{EH}}$ & $\mathrm{kT}$ & $\mathbf{k}_{\mathrm{SP}}$ & $\mathrm{k}_{\mathrm{Fr}}$ & $\mathbf{k}_{\mathrm{COR}}$ & $\begin{array}{l}\mathrm{V}_{\mathrm{N}} \\
\mathrm{S}\end{array}$ & $\mathrm{S}$
\end{tabular}


Jelikož má turbína malé zpoždění $\left(T_{\mathrm{R}}=3 \mathrm{~s}\right)$ a má funkční jak hydraulický regulátor otáček $\left(\mathrm{k}_{\mathrm{Sp}}=20\right)$, tak i korektor frekvence $\left(\mathrm{k}_{\mathrm{COR}}=10\right)$ v regulátoru výkonu, reaguje její výkon NT rychle na odchylku frekvence sítě SU - viz modré průběhy na Obr. 6.1-3.
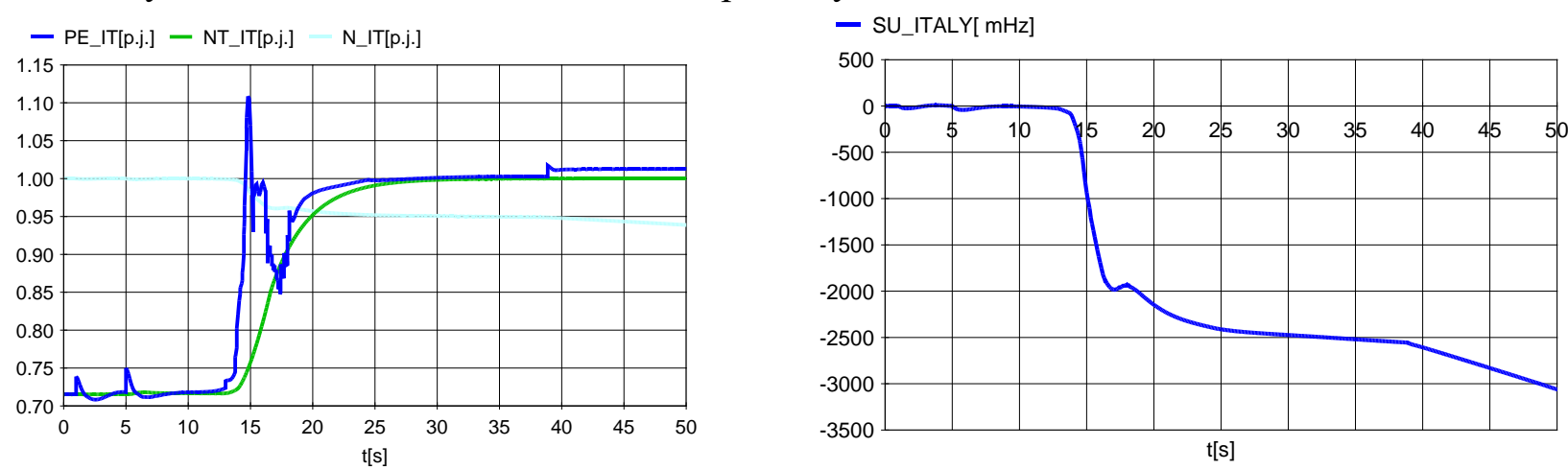

Obr. 6.1-3 Průběhy výkonů generátoru a turbíny a otáček bloku IT (vlevo) a odchylky frekvence (vpravo)

První čtyři poruchy jsou zadány ve scénáři (vypnutí vedení ve Švýcarsku a vedení do Rakouska) do času $\mathrm{t}=13 \mathrm{~s}$. Oslabováním přenosového profilu mezi Švýcarskem a Itálií se více zatěžoval přenosový profil mezi Francií a Itálií a zároveň narůstal úhel napětí v ekvivalentním uzlu ITALY, jak ukazují časové lupy na Obr. 6.1-4.
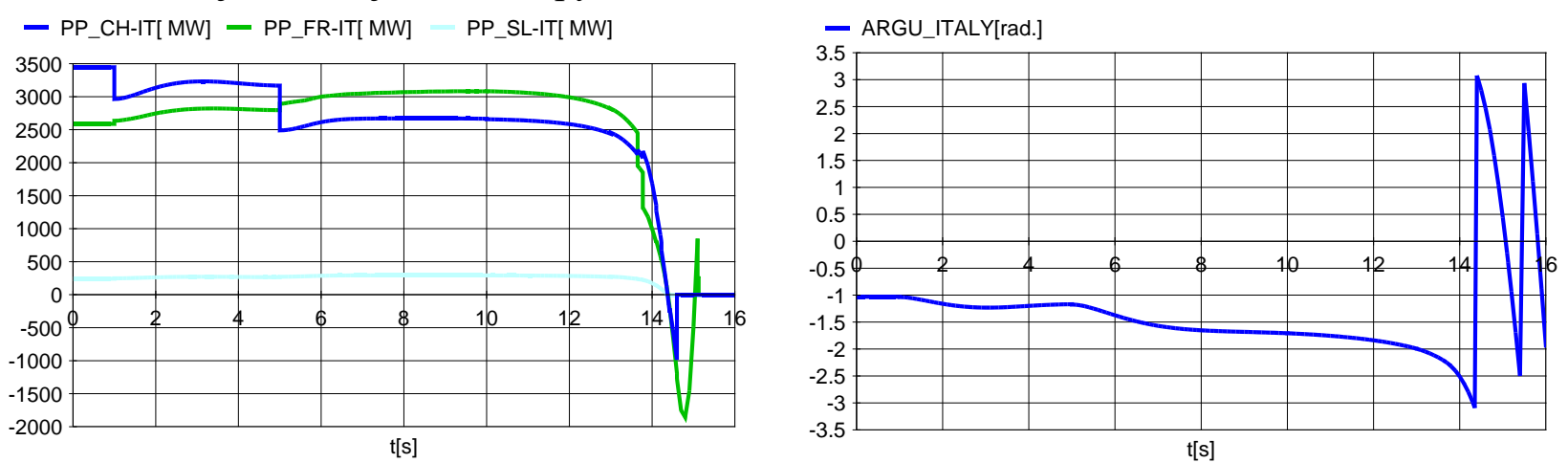

Obr. 6.1-4 Průběhy toků činného výkonu profilů (vlevo) a úhlu napětí ekvivalentního uzlu ITALY (vpravo)

Úhel ARGU v uzlu ITALY odpovídá i rozdílu úhlů uzlů UCTE a ITALY a tím i vlastně zátěžnému úhlu $\delta$ z rovnice (3.1-1). Jakmile úhel překročil hodnotu maxima sinusovky (pro $\delta=\pi / 2$ ), došlo ke ztrátě statické stability a dalšímu poklesu importu. Dokonce se tok výkonu obrátil a tok profilů byl záporný. Rozvírání fázorů napětí má ještě jeden důsledek, a to změnu velikosti napětí na přenosových trasách. Už při hodnotě $\delta$ blížící se $\pi / 2$ klesá napětí v hraničních rozvodnách pod $70 \%$ jmenovité hodnoty a distanční ochrany hraničních vedení naměří zdánlivé impedance (podíl fázorů napětí a proudu) ve svých zónách a dají povel k vypnutí vedení. Během krátké doby necelých $1.5 \mathrm{~s}$ (mezi t $=13.775$ a $15.225 \mathrm{~s})$ dojde k vypnutí všech hraničních vedení distančními ochranami (tzv. kaskádovité výpadky). V čase $\mathrm{t}=13.775 \mathrm{~s}$ se tedy Itálie oddělí od zbytku synchronního propojení UCTE. Tato činnost distančních ochran je naprosto správná, protože od sebe oddělí dvě nesynchronně pracující oblasti.

Pro Itálii to znamená i úlevu, což je patrno na průběhu činného výkonu PE dodávaného generátorem do sítě. V okamžiku oddělení tento výkon klesá o $10 \%$. O dalším přežití ostrova rozhodovalo, jak rychle se obnoví výkonová rovnováha mezi elektrickým výkonem generátorů (daným zatížením ostrova) a poháněcími stroji (turbínami s regulací frekvence a otáček). V modelu se vypínalo (automatikami od podfrekvence) zatížení, což je patrno na poklesu výkonu PE v Obr. 6.1-3 v čase 16.225 - 17.95 s. Současně se ale od podfrekvence vypínaly bloky IT1- IT4, což způsobovalo naopak nárůst výkonu generátoru. Po $30 \mathrm{~s}$ se podařilo výkonovou rovnováhu obnovit, ale v čase $\mathrm{t}=38.875$ s vypnul $200 \mathrm{MW}$ blok IT5 a turbína bloku IT již nebyla schopna zvýšit výkon a pád frekvence byl neodvratný. 


\section{2 Částečný blackout v jižním Řecku v r. 2004}

Následující odstavce jsou převzaty z knihy [4].

Popis je založen na zprávě [52]. Od poloviny devadesátých let se špičkové zatížení ES přesunuje ze zimy do léta hlavně vlivem zvýšeného použití klimatizace a ventilace. Špičkové zatížení vzniká souběhem několika faktorů: velkou teplotou kolem poledne pracovního dne před obdobím dovolených, kdy lidé opouštějí velká města a průmyslová aktivita se snižuje. Přenosová soustava Řecka je náchylná $\mathrm{k}$ napět'ové nestabilitě, což je dáno tím, že velký výkon se přenáší ze severu a západu do míst spotřeby - metropole Atén. Od r. 1996, kdy se objevil první př́ípad napět'ové nestability, byla sít' posilována, ale zatížení sítě dále rostlo vlivem zvýšeného užívání klimatizace a pořádáním olympijských her. Výstavba nové $400 \mathrm{kV}$ rozvodny v Argyroupolii byla zrušena pro nesouhlas obyvatelstva. V kritický den 12. 7. 2004 byly odstaveny pro poruchy a opravy 2 venkovní a 2 kabelová vedení $150 \mathrm{kV}$. Uvedená zařízení nebyla opravena včas částečně i pro nedostatek personálu, který se podílel na přípravě olympiády. To způsobilo velké zatížení autotransformátorů v rozvodně Pallini a pokles napětí v oblasti Atén. V 7:08 vypadl blok 300 MW č. 2 v elektrárně Lavrio v oblasti Atén pro poruchu ve vlastní spotřebě. Blok byl po opravě připojen v síti až v 12:01. Do té doby narůstalo zatížení a napětí klesalo až na $90 \%$. Kolem poledne bylo zatížení jižní části Řecka (Attika a poloostrov Pelopones) 4300 MW a místní výroba $2300 \mathrm{MW}$, takže dovoz se severu činil $2000 \mathrm{MW}$.

Další sled událostí byl následující:

- 12:12 výpadek bloku č. 2 Lavrio, ve snaze umožnit dodávku jalového výkonu pro udržení napětí snižovaly elektrárny v postižené oblasti činný výkon - tím ovšem narůstal import činného výkonu z 2000 na 2400 MW a pokles napětí se ještě zvýšil;

- od 12:25 prováděno ruční odlehčení zatížení o $80 \mathrm{MW}$, které nestačilo na zastavení poklesu napětí a zatížení soustavy dále rostlo;

- 12:37 výpadek bloku č. 3 a vypnutí bloku č. 4 v elektrárně Aliveri.

Během napět'ového kolapsu a ztráty úhlové stability byla vypnuta ochranami vedení $400 \mathrm{kV}$ mezi severem a jihem. V 13:39 se jižní část Řecka oddělila od zbytku přenosové soustavy. V ostrovním provozu nestačila výroba pokrýt zatížení kolem $4500 \mathrm{MW}$, došlo k frekvenčnímu kolapsu a po vypnutí všech zdrojů k blackoutu.

Obr. 6.2-1 ukazuje schéma přenosové sítě 400 kV Řecka s vyznačením místa rozdělení.

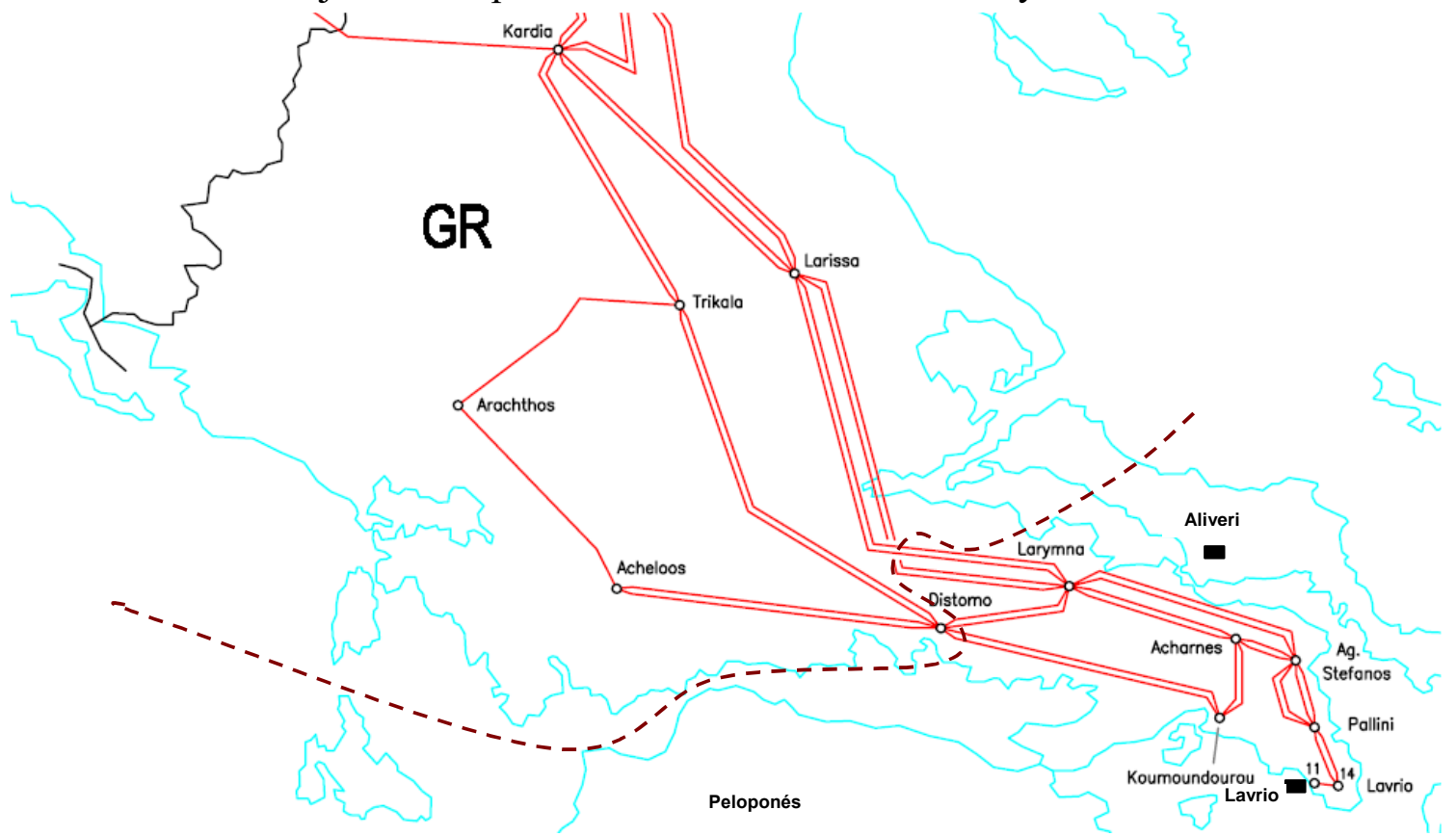

Obr. 6.2-1 Schéma oddělení jižní části Řecka od 2. synchronní zóny UCTE (vyznačeno čárkovaně) 


\section{Př́klad 6-2}

V programu MODES analyzujte dynamické chování modelu synchronního propojení při ztrátě úhlové stability a napět'ového kolapsu na prŕikladu částečného blackoutu Řecka z r. 2004. Uvažujte nejprve statickou zátěž (s konstantním odběrem činného výkonu a odběrem jalového výkonu závislým na kvadrátu napětí) a pak zátěž s asynchronními motory (modelující klimatizační jednotky a ventilátory).

\section{ŘRešení}

V projektu POR_STAB je připraven prrípad BGR2004S, který obsahuje všechna potřebná data pro simulační výpočet.

Obr. 6.2-2 ukazuje jednopólové schéma modelu sítě, kde původní kompletní model synchronního propojení byl zredukován na jeden ekvivalentní uzel UCTE a část jižního Řecka označená ve schématu jako oblast GRSOUT. Tato oblast je zjednodušeně modelována zdrojovým uzlem GR_SOUTH (se soustředěnou výrobou) a dvěma odběrovými uzly. Je zachován přenosový profil mezi severem a jihem Řecka, který zahrnuje 8 vedení 400 kV.

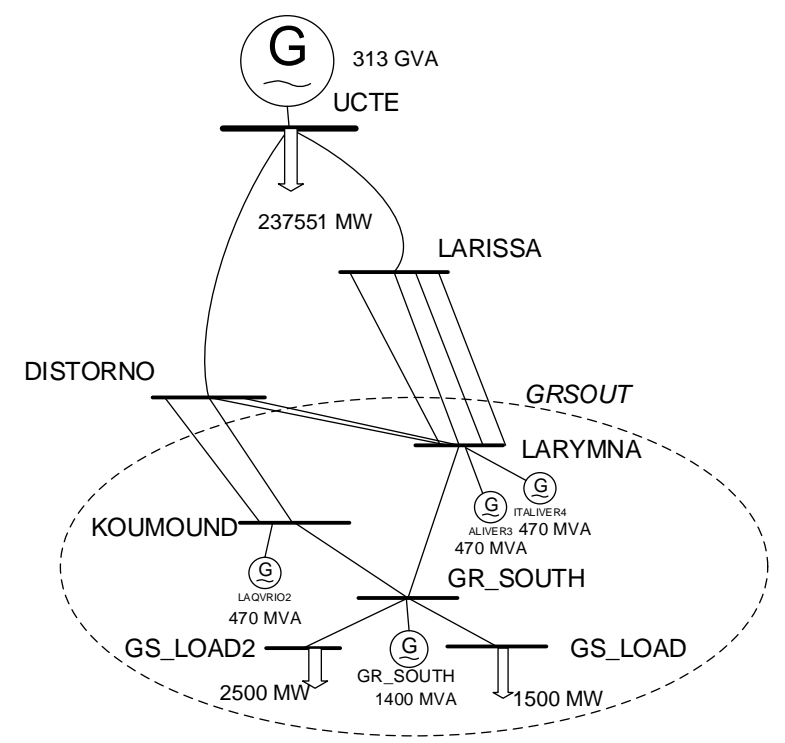

Obr. 6.2-2 Schéma zjednodušeného modelu pro simulační výpočet blackoutu jižního Řecka (GRSOUT)

Pro první př́ípad je pro oba odběrové uzly definována v databázi dynamických modelů uzlů statická zátěž s parametry podle zadání:

\begin{tabular}{|c|c|c|c|c|c|c|c|c|c|c|c|c|c|c|c|c|c|c|c|}
\hline $\begin{array}{l}\text { Jmeno } \\
\text { Uzlu }\end{array}$ & $\begin{array}{l}\mathrm{P} \\
\mathrm{I} \overline{0}\end{array}$ & $\mathrm{P}^{\mathrm{G}}$ & $\begin{array}{l}\mathrm{P} \\
\mathrm{T} \%\end{array}$ & $\frac{Q}{1 \%}$ & $\begin{array}{l}\mathrm{Q} \\
\mathrm{B} \%\end{array}$ & $\begin{array}{l}\mathrm{S} \\
\mathrm{D} \%\end{array}$ & $\mathrm{~S} \overline{\mathrm{S}}$ & $\begin{array}{l}\mathrm{S} \\
\mathrm{M} \text { 응 }\end{array}$ & 1. & $\begin{array}{l}2 . \\
\text { FO응 }\end{array}$ & 3. & 4. & $\begin{array}{c}\text { TypPar } \\
\text { Stat }\end{array}$ & $\begin{array}{r}\text { TypPar } \\
\text { Motor }\end{array}$ & $\begin{array}{l}\text { TypPar } \\
\text { FO }\end{array}$ & & $\begin{array}{l}\text { TypPar } \\
\text { Ter }\end{array}$ & & $\begin{array}{c}\text { TypPar } \\
\text { Dyn }\end{array}$ \\
\hline 'GS $\overline{L O A D} \bar{\prime}$ & $\overline{0}$ & 0 & 0 & 0 & $\overline{0}$ & $\overline{0}$ & 100 & $\overline{0}$ & 0 & 0 & $\overline{0}$ & $\overline{0}$ & ' STATGR' & ' & 1 & ' & ' & 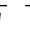 & $T$ \\
\hline 'GS_LOAD2 ' & 0 & 0 & 0 & 0 & 0 & 0 & 100 & 0 & 0 & 0 & 0 & 0 & ' STATGR' & ' & ' & ' & ' & & ' \\
\hline
\end{tabular}

Sada parametrů pro statický model zátěže je definována v katalogu typových parametrů modelů uzlu:

Tab. 6.2-1 Typové parametry statické zátěže

\begin{tabular}{|l|l|l|l|l|l|l|l|l|ll|}
\hline Stat_char & $\mathrm{Ap}(-)$ & $\mathrm{Bp}(-)$ & $\mathrm{Cp}(-)$ & $\mathrm{A} 0(-)$ & $\mathrm{B} 0(-)$ & $\mathrm{C} 0(-)$ & Umin $(-)$ & - & Komentář & \\
\hline STATGR & 0 & 0 & 0 & 0 & 0 & 0 & 0.5 & & P=konst. & Q U*U \\
\hline
\end{tabular}

Takto zadané parametry určují odběr činného a jalového výkonu podle rovnic (5.2-1) pro poměrné napětí větší než Umin, pak se zátěž změní na admitanční (s odběrem výkonu závislým na kvadrátu napětí). 
Pro modelování napět'ových kolapsů je (kromě modelů zátěže) důležité definovat přesněji modely regulátorů buzení bloků, které udržují napětí sítě v předepsaných mezích. V našem př́ípadě má blok GR_SOUTH definován v databázi dynamických modelů bloků tento záznam:

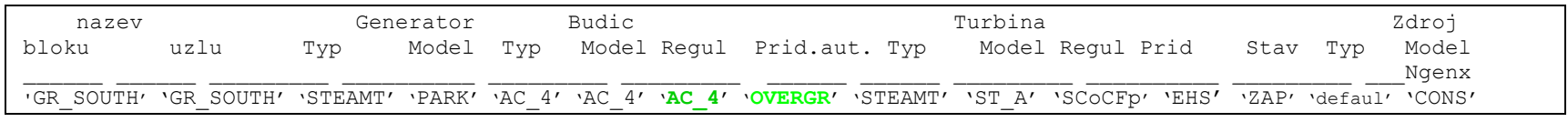

Důležitou roli pak hraje omezovač statorového a rotorového proudu, který je jako tzv. př́davná automatika součástí modelu regulátoru buzení zobrazeného na následujícím obrázku.

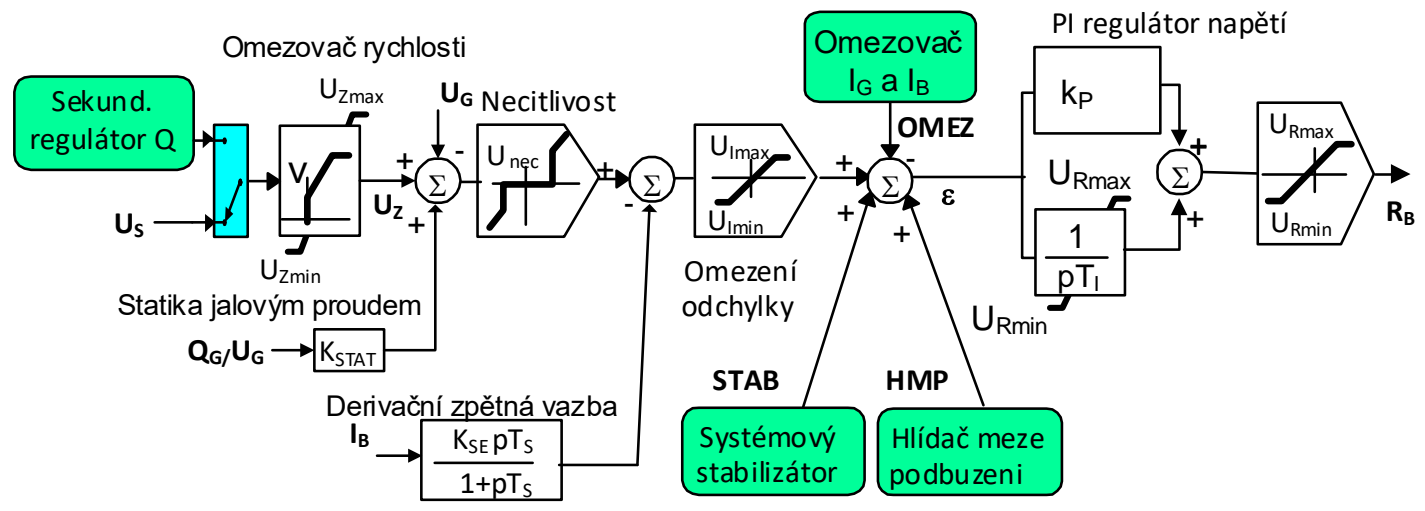

Obr. 6.2-3 Zjednodušené blokové schéma modelu regulátoru buzení

Typové parametry regulátoru buzení jsou v následující tabulce:

Tab. 6.2-2 Typové parametry regulátoru buzení

\begin{tabular}{|l|l|l|l|l|l|l|l|l||l|l|l|l|}
\hline Regulatory_B & $\begin{array}{l}\text { Uzmin } \\
(-)\end{array}$ & $\begin{array}{l}\text { Uzmax } \\
(-)\end{array}$ & $\begin{array}{l}\text { Unec } \\
(-)\end{array}$ & $\begin{array}{l}\text { Kstat } \\
(-)\end{array}$ & $\begin{array}{l}\text { Kp } \\
(-)\end{array}$ & $\begin{array}{l}\text { Kse } \\
(-)\end{array}$ & $\begin{array}{l}\text { TI } \\
(\mathrm{s})\end{array}$ & $\begin{array}{l}\text { Ts } \\
(\mathrm{s})\end{array}$ & $\begin{array}{l}\text { U } \\
(\% / \mathrm{s})\end{array}$ & $\begin{array}{l}\text { Urmax } \\
(-)\end{array}$ & $\begin{array}{l}\text { Urmin } \\
(-)\end{array}$ & $\begin{array}{l}\text { Koment } \\
(\text { text })\end{array}$ \\
\hline AC_4 & 0.9 & 1.1 & 0 & 0 & 25 & 0 & 0.14 & 1 & 0.9 & 9.5 & -9.5 & regulátor bez DZV \\
\hline
\end{tabular}

Blokové schéma modelu omezovače statorového a rotorového proudu a jeho funkce byla popsána v kap. 5.3, takže zde uvedeme jen jeho parametry pro modelování blackoutu v Řecku.

Tab. 6.2-3 Typové parametry omezovače statorového a rotorového proudu

\begin{tabular}{|l|l|l|l|l|l|l|l|l|}
\hline Automatiky_B & $\ldots .$. & UOMmax (-) & UOMzad (-) & TiOM. . (s) & TOM. . (s) & . . & IBmax (-) & IGmax (-) \\
\hline OVERGR & & 0.3 & 10 & 1 & 2 & & 1 & 1 \\
\hline
\end{tabular}

Působení ochran je v modelu provedeno pomocí tzv. automatik. Jejich podrobný popis je v elektronické dokumentace k programu MODES v položce Popis modelování/Řízení a ochrany ES/Model automatik po kliknutí na záložku Dokumentace). Následující výpis ukazuje obsah vstupního souboru AUTOMAT.001, který obsahuje vstupní data automatik:

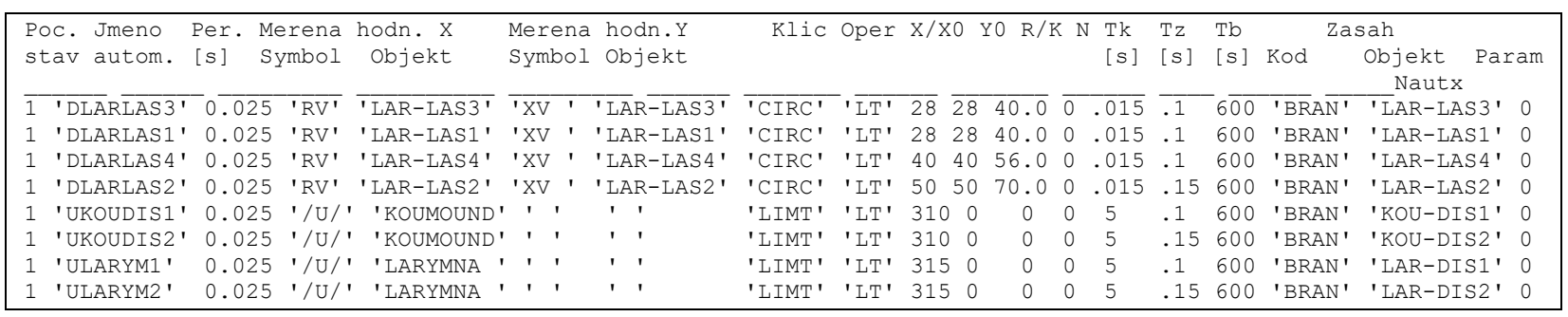

První čtyři automatiky modelují distanční ochranu, která měří v komplexní rovině zdánlivou impedanci jako podíl fázorů fázového napětí a proudu vedení $\left(\underline{Z_{v}}=R_{v}+j X V=\underline{U_{f}} / \underline{I} v\right)$. Pokud se měřená impedance dostane do charakteristiky ochrany, kterou tvoří vysunutá kružnice (se středem $\mathrm{X} 0, \mathrm{Y} 0$ a poloměrem $\mathrm{R}$ ), po dobu $\mathrm{T}_{\mathrm{k}}$ provede automatika se zpožděním $\mathrm{T}_{\mathrm{k}}$ zadaný zásah - vypne vedení, na kterém se měření impedance provádí. Další čtyři automatiky modelují podpětovou ochranu, která při poklesu napětí v uzlu pod zadanou hodnotu $\mathrm{X}$ po dobu $\mathrm{T}_{\mathrm{k}}$, provede se zpožděním $T_{k}$ opět vypnutí vedení, které je do uzlu připojeno. Po dobu $T_{b}$, je činnost automatiky blokována. 
Následující obrázek ukazuje výsledky výpočtu, kdy se v časech t $=1,10$ a 20 s odpojily bloky (s dodávkou po $300 \mathrm{MW}$ ) od sítě.
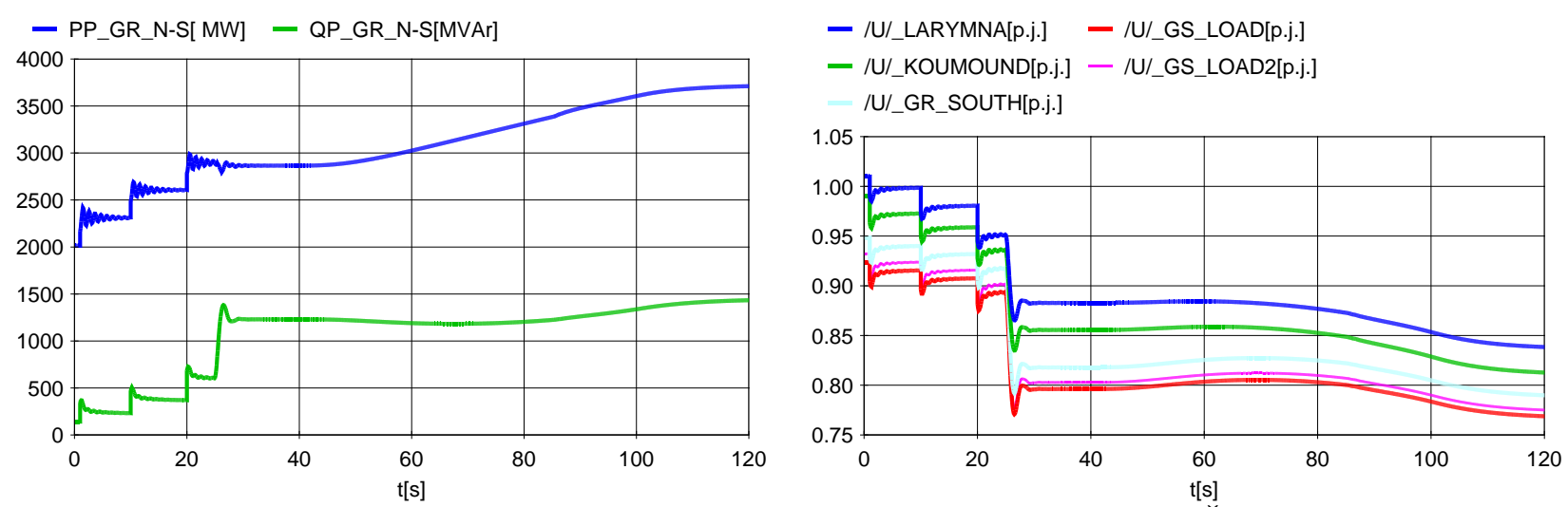

Obr. 6.2-4 Průběhy toků činného výkonu profilu (vlevo) a napětí v uzlech jižní části Řecka (vpravo)

Výpadky bloků jsou patrny jak na průbězích toku profilu GR_N-S (skládá se z osmi vedení $400 \mathrm{kV}$ ), tak i na napětích. V čase $\mathrm{t}=24.8 \mathrm{~s}$ zapůsobil omezovač statorového proudu na bloku GR_SOUTH a blok po odbuzení razantně snížil dodávku jalového výkonu QG do sítě, jak je vidět levé části Obr. 6.2-5.
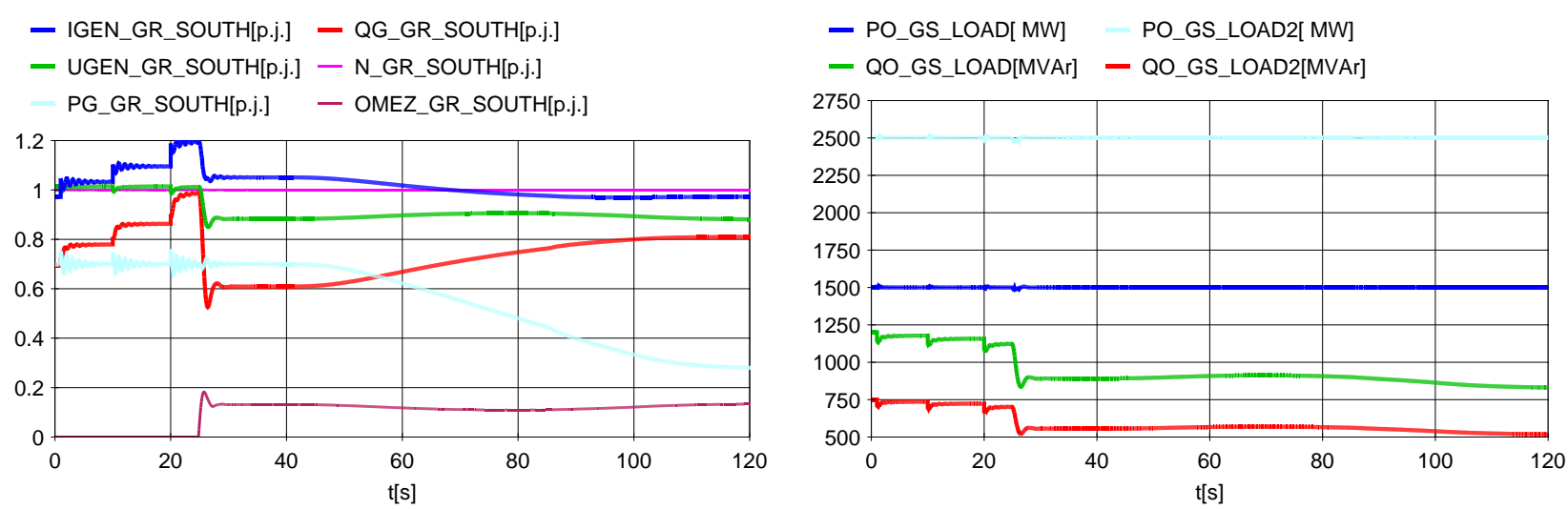

Obr. 6.2-5 Veličiny bloku GR_SOUTH (vlevo) a výkony zátěže v odběrových uzlech (vpravo)

$\mathrm{V}$ čase $\mathrm{t}=40 \mathrm{~s}$ byl ve scénáŕi zadán zásah na snížení činného výkonu o polovinu během jedné minuty. Odlehčení odstranilo přetížení bloku (proud generátoru IGEN klesl pod jmenovitou hodnotu 1) a zvětšilo dodávku jalového výkonu do sítě. Průběhy napětí ale ukazují, že po $\mathrm{t}=80$ s napětí v síti začalo klesat a v odběrových uzlech se blížilo $75 \%$ jmenovité hodnoty.

$\mathrm{Na}$ grafech vpravo jsou vidět výkony zátěží. Činný výkon je v souladu se zadáním konstantní. Jalový výkon se naopak mění s kvadrátem napětí a pomáhá tak stabilizovat sít'.

Pro druhý př́pad BGR2004M je zatížení v uzlu GS_LOAD modelováno ekvivalentním asynchronním motorem známým již z Př́íkladu 5.2.

Parametry pro model jsou definovány v katalogu typových parametrů modelů uzlu:

Tab. 6.2-4 Typové parametry modelu asynchronního pohonu

\begin{tabular}{|l|l|l|l|l|l|l|l|l||ll|}
\hline Ekv motor & Am $(-$ & Bm $(-$ & Tm $(\mathrm{s})$ & $\mathrm{R} 1(-)$ & X1 $(-$ & Xmi $(-$ & R2 $(-)$ & X2 $(-)$ & Koment & \\
\hline ASLDGR & 0 & 1 & 10 & 0.016 & 0.07 & 2.95 & 0.0226 & 0.368 & Pohony s ventilatory \\
\hline
\end{tabular}

Podobně jako u Př́kladu 5.2 parametry Am a Bm definují kvadratickou závislost momentu zátěže na otáčkách, kterou mají ventilátory.

Záznamy v modifikované databázi dynamických modelů uzlu se změní podle výpisu:

\begin{tabular}{|c|c|c|c|c|c|c|c|c|c|c|c|c|c|c|c|c|c|}
\hline $\begin{array}{l}\text { Jmeno } \\
\text { Uzlu }\end{array}$ & $\begin{array}{l}\mathrm{P} \\
\mathrm{I} \%\end{array}$ & $\mathrm{P}_{\overline{\mathrm{O}}}$ & $\begin{array}{l}\mathrm{P} \\
\mathrm{T} \%\end{array}$ & $\begin{array}{l}\mathrm{Q} \\
\mathrm{I} \%\end{array}$ & Q & $\mathrm{S}$ & $\mathrm{S}$ & $\begin{array}{l}\mathrm{S} \\
\mathrm{M} \%\end{array}$ & 1. & $\begin{array}{l}2 . \\
\mathrm{FO}\end{array}$ & 3. & 4. & $\begin{array}{l}\text { TypPar } \\
\text { Stat }\end{array}$ & $\begin{array}{r}\text { TypPar } \\
\text { Motor }\end{array}$ & $\begin{array}{l}\text { TypPar } \\
\text { FO }\end{array}$ & $\begin{array}{c}\text { TypPar } \\
\text { Ter }\end{array}$ & $\begin{array}{l}\text { TypPar } \\
\text { Dyn }\end{array}$ \\
\hline ' $\overline{\mathrm{GS}} \overline{\mathrm{LO}} \overline{\mathrm{AD}} \cdot$ & 0 & 0 & 0 & 0 & 0 & 0 & 0 & 100 & 0 & 0 & 0 & 0 & ' & 'ASLDGR' & ' & ' & ' ' \\
\hline 'GS_LOAD2 ' & 0 & 0 & 0 & 0 & 0 & 0 & 100 & 0 & 0 & 0 & 0 & 0 & 'STATGR' & ' & ' & ' ' & ' ' \\
\hline
\end{tabular}


Obr. 6.2-6 ukazuje výsledky výpočtu na stejném scénáři jako u předchozího případu.
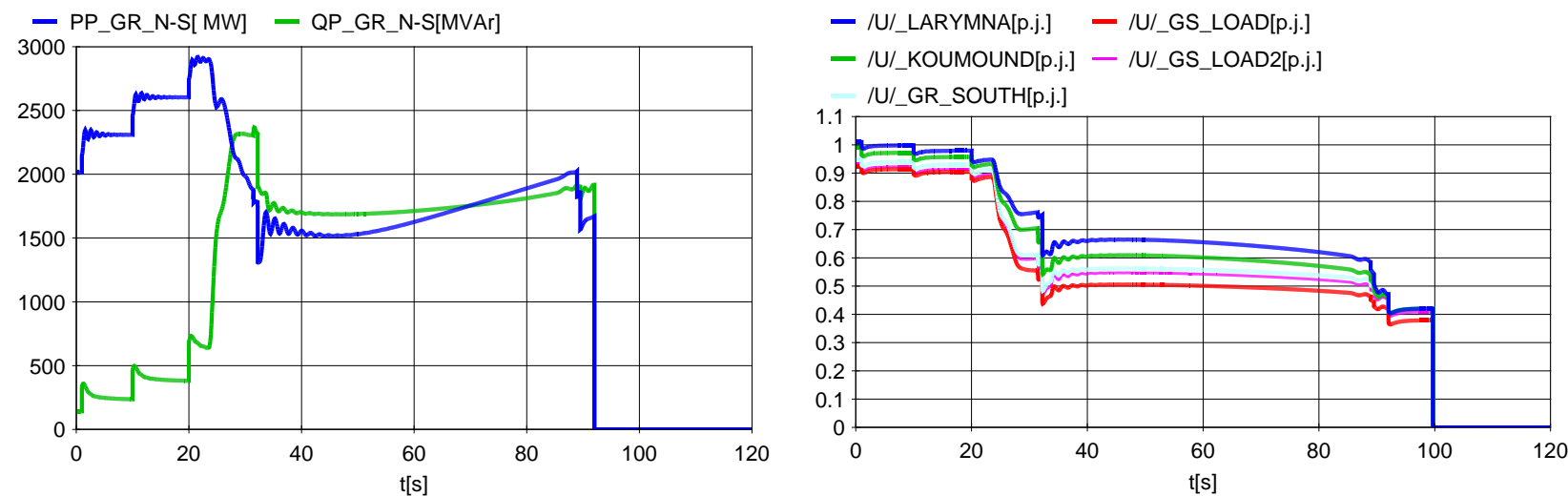

Obr. 6.2-6 Průběhy toků činného výkonu profilu (vlevo) a napětí v uzlech jižní části Řecka (vpravo)

Až do působení omezovače statorového proudu $\mathrm{v}$ čase $\mathrm{t}=23.45 \mathrm{~s}$ jsou průběhy podobné jako v předchozím případě, ale poté následuje prudký nárůst přenášeného jalového výkonu a pokles napětí. Příčinou nárůstu je lavina napětí (popsaná u Př́ikladu 5.2), která způsobí, že se motor zastaví a odebírá velký zkratový výkon, jak ukazuje Obr. 6.2-7 vpravo v t $=30 \mathrm{~s}$.
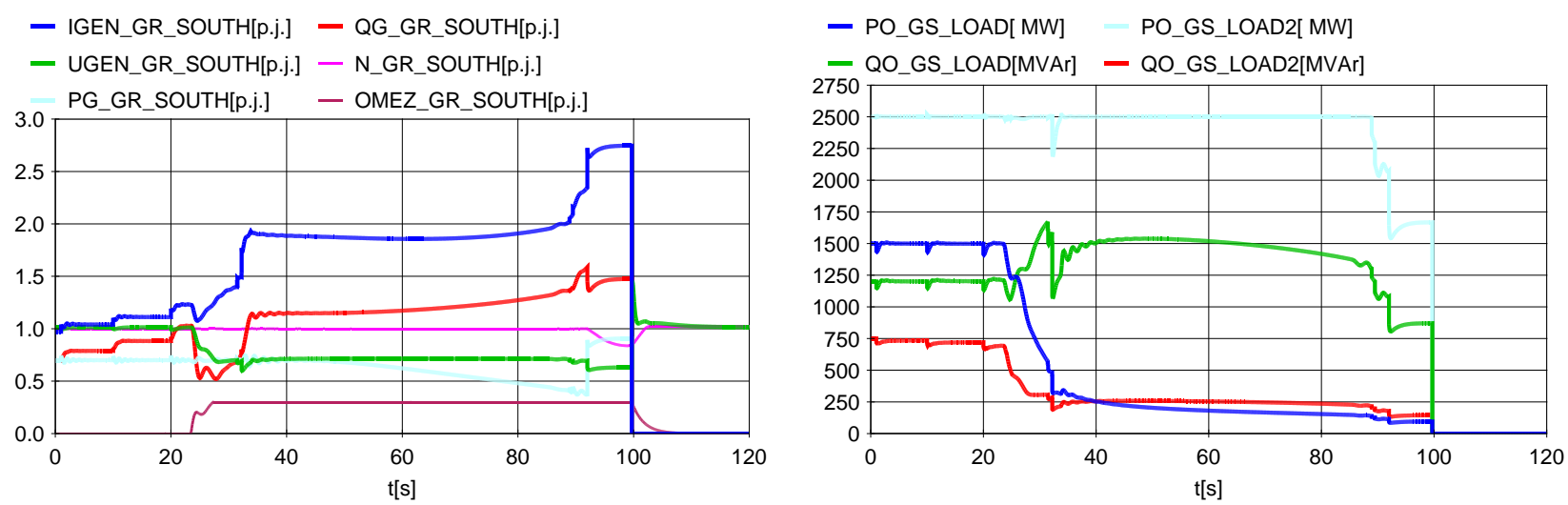

Obr. 6.2-7 Veličiny bloku GR_SOUTH (vlevo) a výkony zátěže v odběrových uzlech (vpravo)

$\mathrm{V}$ čase $\mathrm{t}=31.425 \mathrm{~s}$ vypínají podpět'ové ochrany první vedení na profilu. Krátce po sobě byly od poklesu napětí vypnuty 4 vedení z uzlu DISTORNO. To způsobí další pokles napětí, na které reaguje blok GR_SOUTH zvýšením dodávky jalového výkonu QG za cenu velkého proudového přetížení. Činný výkon generátoru klesá od řízeného poklesu výkonu turbíny (zásahem $\mathrm{v} t=40 \mathrm{~s}$ ). To ovšem způsobí další pokles napětí a po devadesáté sekundě jsou distančními ochranami vypnuta zbývající vedení profilu a oblast GRSOUT přejde do ostrova. Nyní musí blok GR_SOUTH pokrývat zatížení ostrova, jeho otáčky N prudce klesají a v t $=100 \mathrm{~s}$ je blok vypnut ochranami, čímž ostrov ztratí napájení.

Simulační výpočet reálné poruchy demonstruje rychlý průběh napětového kolapsu. Neměl tedy po iniciační poruše nějaký plíživý charakter, který by mohl být vyhodnocen nějakým predikčním relé, které by včas varovalo dispečery a připravilo je k provedení razantních nápravných opatření jako je vypínání zátěže.

Je také ukázáno, že za napětovým kolapsem nestojí ani tak nějaké tajemné bifurkace, jako spíš prozaická funkce omezovačů proudů v regulátorech buzení synchronních generátorů a zvýšený odběr jalového výkonu asynchronních motorů při poklesech napětí. 


\subsection{Působení frekvenčního odlehčování v Anglii v r. 2019}

Popis je založen na zprávě [47]. V pátek 9. 8. 2019 před pátou hodinou odpolední probíhal provoz sítí ve Velké Británii normálně s bouřkami a deštěm. Bylo teplo a větrno. Zatížení soustavy bylo obvyklé a pokrývaly je z 30 \% větrné elektrárny, z $30 \%$ plynové a z $20 \%$ jaderné elektrárny. Zbytek pokrýval z $10 \%$ import a asi z $10 \%$ distribuovaná výroba.

Další sled událostí byl následující:

- 16:52:33 udeřil blesk do vedení Eaton Socon - Wymondley Main, vedení bylo vypnuto ochranami během $0.1 \mathrm{~s}$ a po $20 \mathrm{~s}$ znovu zapnuto

- pokles napětí při zkratu způsobil výpadek $500 \mathrm{MW}$ rozptýlených zdrojů v distribuční soustavě;

- krátce po úderu blesku během několika sekund došlo k výpadku výkonu 737 MW větrné farmy Hornsea a parního bloku PPC Little Barford o výkonu 244 MW;

- frekvence se stabilizovala na 49.2 Hz aktivací primární regulační rezervy kolem 1000 MW;

- 16:53:31 byl vypnut plynový blok PPC Little Barford o výkonu 210 MW;

- 16:53:49 frekvenční odlehčování při podfrekvenci 48.8 Hz vypíná 931 MW zátěže.

Po odlehčení se frekvence zotavila a došlo jen k výpadku zbývajícího bloku PPC Little Barford o výkonu $187 \mathrm{MW}$. Po aktivaci dalších rezervních výkonů se frekvence vrací k $50 \mathrm{~Hz}$.

Obr. 6.3-1 ukazuje část přenosové sítě $400 \mathrm{kV}$ Anglie s vyznačením místa poruch.

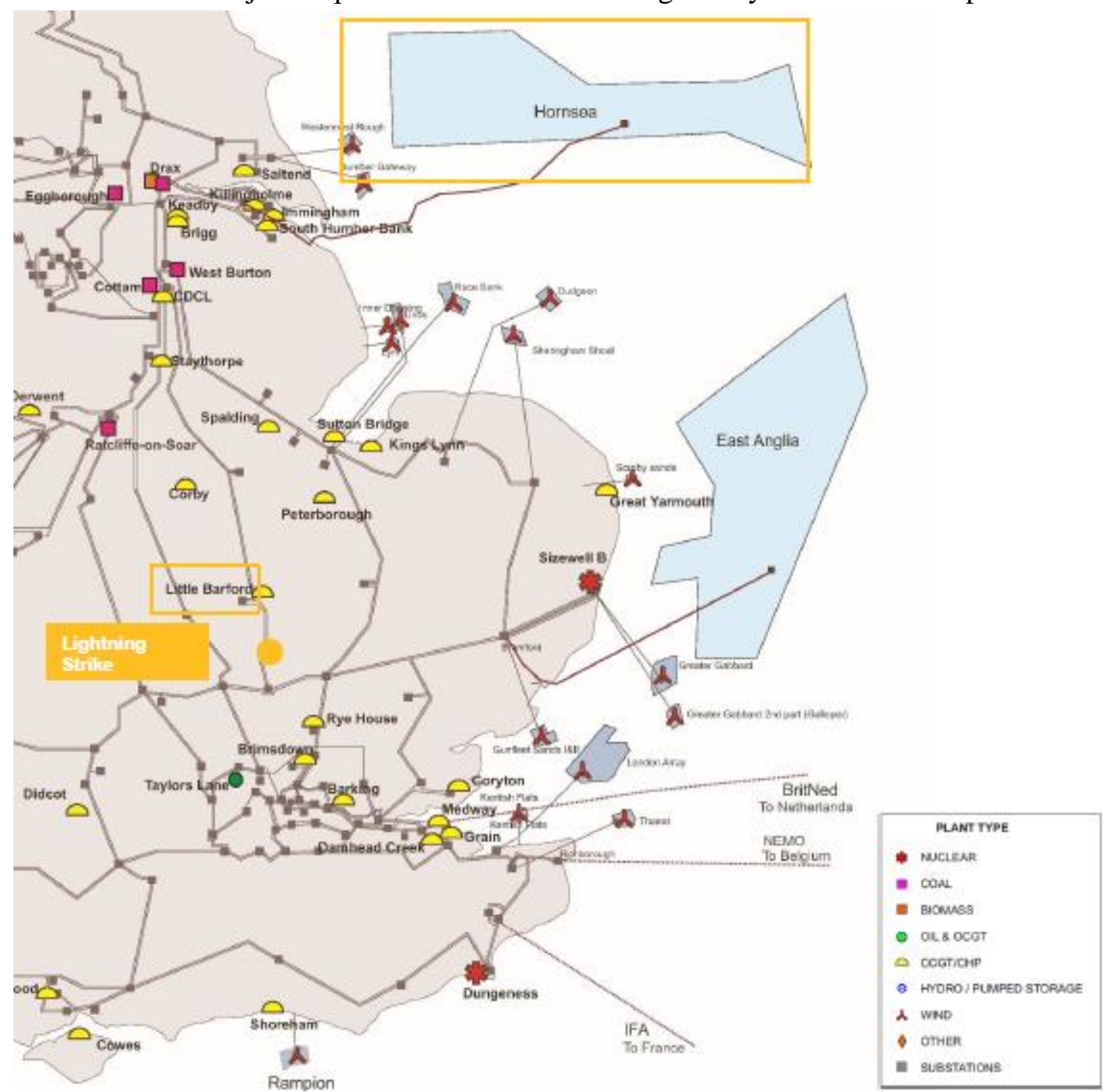

Obr. 6.3-1 Schéma přenosové sítě s vyznačením míst poruch (převzato z [47]) 


\section{Příklad 6-3}

Analyzujte na jednouzlovém modelu frekvenční stabilitu na př́kladu poruch $\mathrm{v}$ Anglii z roku 2019. U plynových turbín uvažujte nejprve jen regulaci otáček a pak i regulaci výkonu.

\section{ŘŘení}

V projektu POR_STAB je připraven př́pad FGB2019S, který obsahuje potřebná data pro simulační výpočet prŕípadu, kdy plynové turbíny pracují jen v regulaci otáček.

Obr. 6.3-2 ukazuje schéma jednouzlového modelu sítě, kde jednotlivé komponenty modelu jsou připojeny do jednoho uzlu přes větve s malou impedancí (spínače).

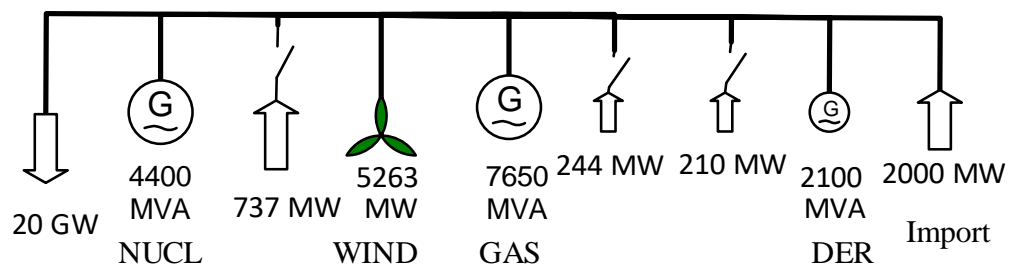

Obr. 6.3-2 Schéma jednouzlového modelu pro simulační výpočet frekvenční stability při poruše v Anglii

Celkové zatížení bylo odhadnuto na $20 \mathrm{GW}$ (při frekvenčním odlehčení bylo vypnuto asi $5 \%$ celkové zátěže). Pokrytí výkonu a rozdělení na jednotlivé typy zdrojů odpovídá údajům o poruše (30 \% větrné, $30 \%$ plynové, $20 \%$ jaderné a $10 \%$ distribuované zdroje, zbytek tvořil import). Pro simulaci výpadků bylo 737, 244 a 220 MW dodávky modelováno jako konstantní admitance vypínaná spínačem. Ostatní zdroje jsou modelovány příslušnými modely.

Pro větrné elektrárny byl použit model větrné turbíny WIND spolu s modelem plno výkonového měniče označený PMGC (viz také příspěvek [53]). Parametry modelu WIND jsou nastaveny tak, že zdroj nereaguje na odchylky frekvence a dodává konstantní výkon do sítě.

Pro jaderné (blok NUCL) a distribuované (blok DER) zdroje je použit model parní turbíny ST_A zobrazený na následujícím obrázku.

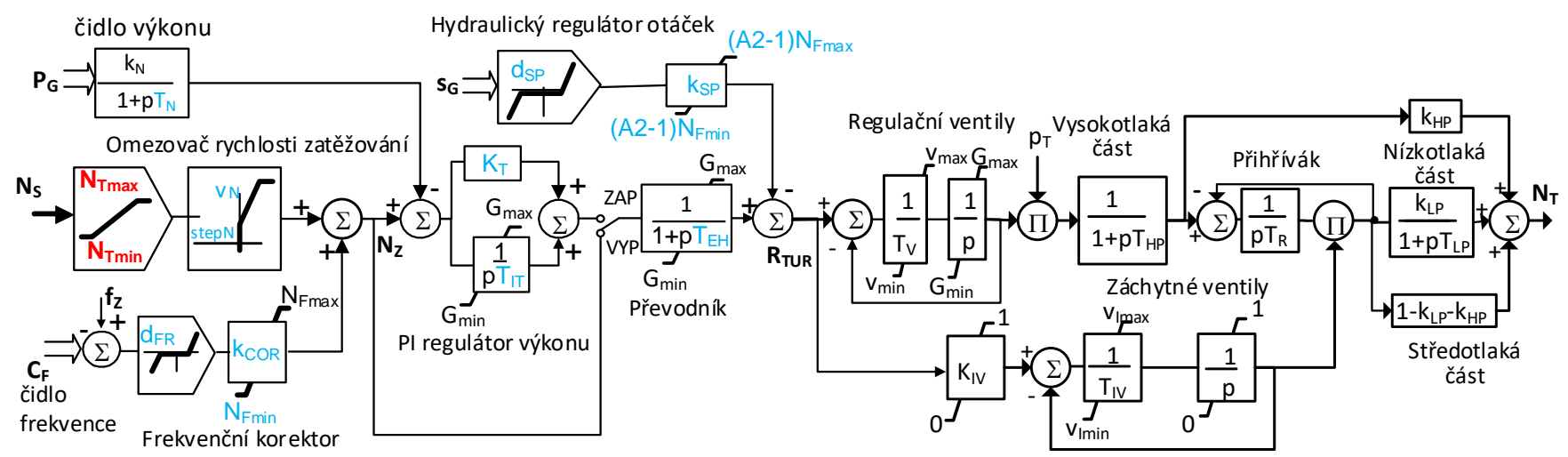

Obr. 6.3-3 Zjednodušené blokové schéma modelu parní turbíny ST_A (vpravo) s obecným regulátorem

$\mathrm{Na}$ rozdíl od zjednodušeného modelu turbíny STAN (na Obr. 4.2-1) se podrobněji modeluje průtok páry středotlakou a nízkotlakou částí. Výstup hydraulického regulátoru otáček lze omezit pomocí parametru $\mathrm{A} 2 \geq 2$. Parametry pro modely turbín a regulátorů jsou v tabulkách:

Tab. 6.3-1 Typové parametry modelu parní turbíny ST_A a regulátorů pro bloky NUCL a DER

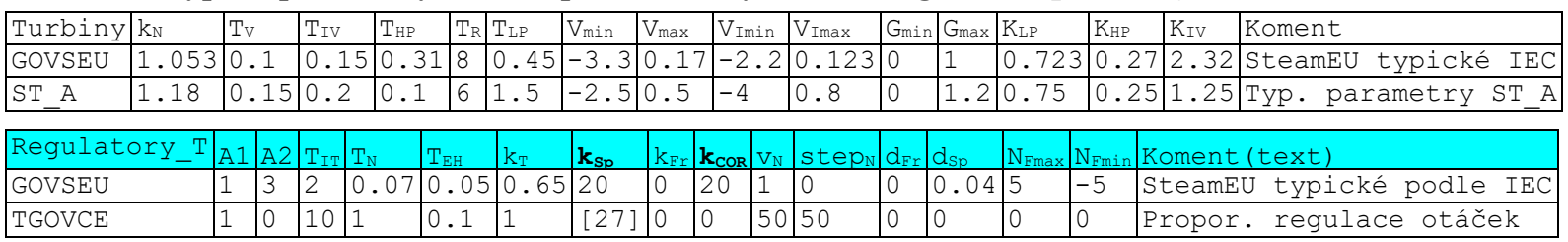

Parametry bloku byly zvoleny jako typické pro model GovSteamEU podle standardu IEC [27]. O převodu modelů turbín IEC na modely programu MODES pojednává prríspěvek [54]. 
Při volbě přepínače VYP v modelu regulátoru se na výstup regulátoru $\mathrm{R}_{\mathrm{TUR}}$ dostává zadaný výkon $\mathrm{N}_{Z}$ (po průchodu elektrohydraulickým prrevodníkem), ke kterému lze přičíst výstup hydraulického regulátoru otáček. Pak se jedná o tzv. řízení v otevřené regulační smyčce (regulátor výkonu je přemostěn). Tento způsob řízení je použit u bloku DER - lze tak měnit otevření regulačních ventilů a tím i výkon turbíny změnou požadovaného výkonu Ns.

U bloku NUCL je přepínač v poloze ZAP, kdy výkon turbíny řídí PI regulátor výkonu, který vyreguluje otevření regulačních ventilů přesně tak, aby generátor dodával do sítě přesně zadaný výkon $\mathrm{N}_{Z}$. Opět lze prričíst výstup hydraulického regulátoru otáček. Jedná se o tzv. paralelní uspořádání regulátoru výkonu a otáček. Díky hydraulickému regulátoru otáček reaguje turbína na odchylku otáček bezprostředně, tato reakce je ovšem eliminována regulátorem výkonu. Pro trvalou reakci výkonu turbíny na změny otáček a frekvence sítě musí být v regulátoru výkonu korektor frekvence, který upraví požadovanou hodnotu výkonu.

Pro plynové zdroje (blok GAS) byl použit alternativní model GASA, který je kompatibilní s modelem GOVCT1 podle standardu IEC [27]. Model je zobrazený na Obr. 6.3-4:

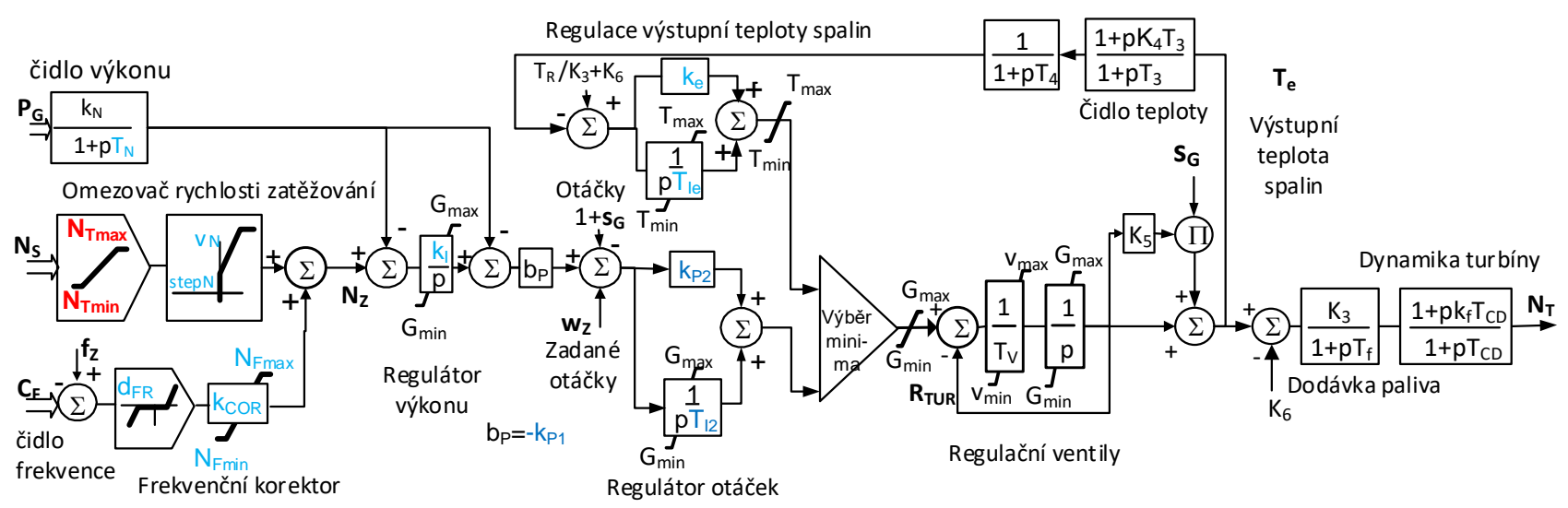

Obr. 6.3-4 Zjednodušené blokové schéma alternativního modelu plynové turbíny (vpravo) s regulátorem

Regulátor turbíny se skládá vlastně ze tří dílčích regulátorů. Základ tvoří regulátor otáček, který je v sérii s regulátorem výkonu, který modifikuje zadanou hodnotu regulátoru otáček. Regulátor výkonu se dá volbou $K_{I}=0$ vyřadit a pak se jedná o čistou regulaci otáček, která je ovšem proporcionální díky vazbě na výkon generátoru $\mathrm{P}_{\mathrm{G}}$ přes trvalou statiku $\mathrm{b}_{\mathrm{P}}$. Součástí modelu je i regulátor teploty výstupních plynů, který zajišt’uje, aby výkon turbíny trvale nepřesáhl limitní hodnotu $T_{R}$. Parametry pro modely turbín a regulátorů jsou $\mathrm{v}$ tabulkách:

Tab. 6.3-2 Typové parametry modelu plynové turbíny GASA a regulátorů pro blok GAS

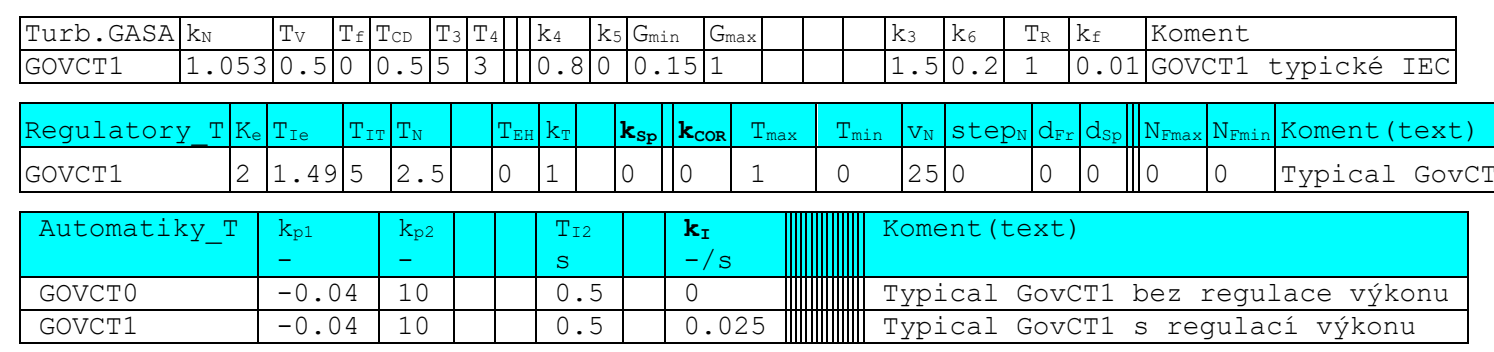

V připraveném př́padu FGB2019S je zadána sada GOVCTO pro typové parametry regulátoru otáček $\mathrm{s} \mathrm{K}_{\mathrm{I}}=0$ a regulace je zadána do režimu $\mathrm{SPD}$, takže program MODES přiřadí turbíně regulátor podle Obr. 6.3-4.

Je modelován regulační efekt zátěže o velikosti $1 \% / \mathrm{Hz}$. Sady typových parametrů statické zátěže je definována v katalogu typových parametrů modelů uzlu podle Tab. 6.3-3.

Tab. 6.3-3 Typové parametry statické zátěže

\begin{tabular}{|l|l|l|l|l|l|l|l|l|l|}
\hline Stat_char & $\mathrm{Ap}(-)$ & $\mathrm{Bp}(-)$ & $\mathrm{Cp}(-)$ & $\mathrm{AO}(-)$ & $\mathrm{B} 0(-)$ & $\mathrm{CO}(-)$ & Umin $(-)$ & - & Komentář \\
\hline REGEF1 & 0 & 0 & 0.5 & 0 & 0 & 0 & 0.8 & Regulační efekt zátěže 1\%/Hz \\
\hline
\end{tabular}


Obr. 6.3-5 ukazuje výsledky výpočtu, $k d y$ v časech $t=1,2$ a 60 s byly vypnuty výkony 737, 244 a 220 MW (simulace výpadků větrné farmy, parního a plynového bloku PPC). Výpadek rozptýlených zdrojů byl simulován snížením výkonu bloku DER ve třech skocích po $10 \%$ $\mathrm{v}$ časech $2.1,4$ a $6 \mathrm{~s}$.

Obrázek vpravo ukazuje průběh frekvence s počátečním prudkým poklesem bržděným jen setrvačností synchronních strojů a regulačním efektem zátěže. Po určitém zpoždění na pokles frekvence zareagují zdroje v primární regulaci frekvence (viz kap. 4.2), jak ukazují grafy vpravo. Blok GAS s plynovou turbínou reaguje velmi rychle a zvýší výkon o $16 \%$ během $10 \mathrm{~s}$. Rychlá reakce je daná velkým zesílením regulátoru otáček $\mathrm{k}_{\mathrm{P} 2}=10$ a malým zpožděním $\mathrm{T}_{\mathrm{CD}}=0.5 \mathrm{~s}$. Reakce bloku NUCL s parní turbínou je pomalejší vlivem zpoždění v částech parní turbíny. Přesto parní turbína dosáhne svého maximálního výkonu během 20 s. Poté se její výkon sníží, protože převáží vliv regulátoru výkonu a výkon je zregulován na počáteční hodnotu $94 \%$ zvětšenou o hodnotu $\mathrm{N}_{\mathrm{Fmax}}=5 \%$. Pokles výkonu parní turbíny nahradí plynová turbína bloku GAS, který má stále rezervu do maxima. Po výpadku výkonu $220 \mathrm{MW} v \mathrm{t}=60 \mathrm{~s}$ se výkon plynové turbíny zvýší na $101 \%$ a se zpožděním kolem 35 s vyreguluje regulátor teploty výstupních plynů výkon turbíny na maximální výkon $100 \%$. I po snížení zůstává frekvence nad kritickou mezí $48.8 \mathrm{~Hz}$ pro odlehčování zátěže. Dispečeři řídící soustavu tak mohou aktivovat dodatečný výkon (např̀. rychle startující zdroje) pro návrat frekvence do normálních mezí.
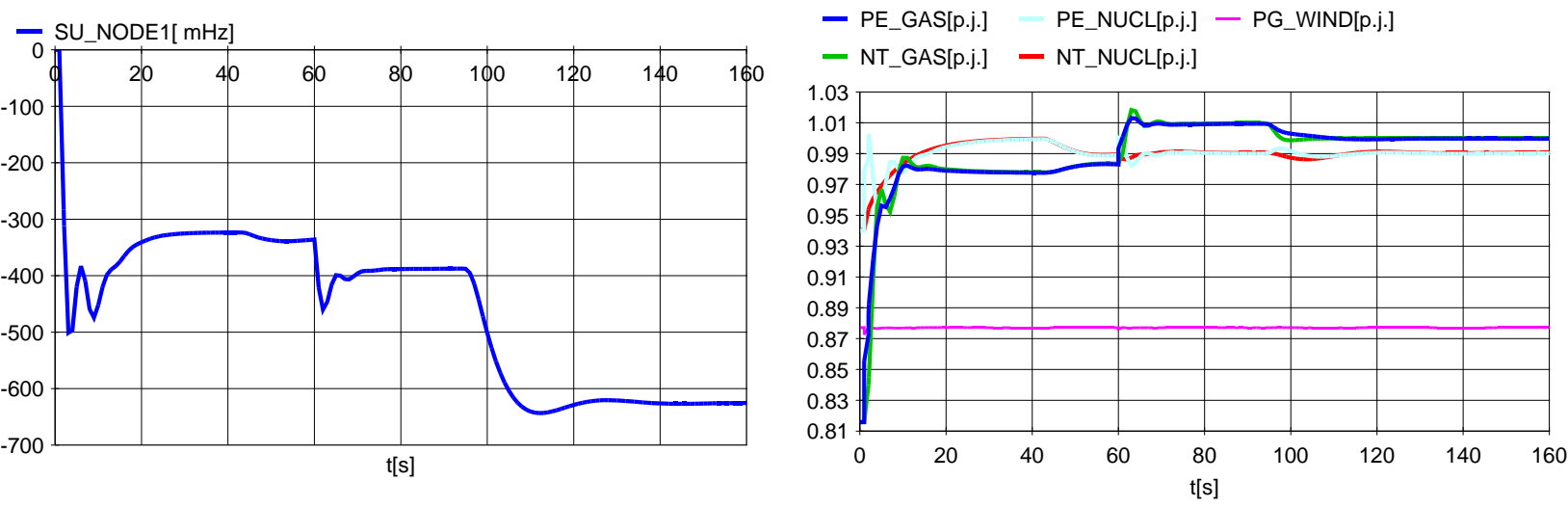

Obr. 6.3-5 Odchylka frekvence sítě (vlevo) a výkony zdrojů (vpravo) pro plynovou turbínu v regulaci otáček

V druhém př́padu FGB2019U má blok GAS zadánu sadu GOVCT1 pro parametry regulátoru otáček s $\mathrm{k}_{\mathrm{I}}=0.025 \mathrm{~s}^{-1}$, čili je funkční regulátor výkonu určený pro regulaci turbíny, pokud je blok v dálkovém řízení s požadovaným výkonem N $\mathrm{N}_{\mathrm{S}}$. Průběhy jsou na Obr. 6.3-6.
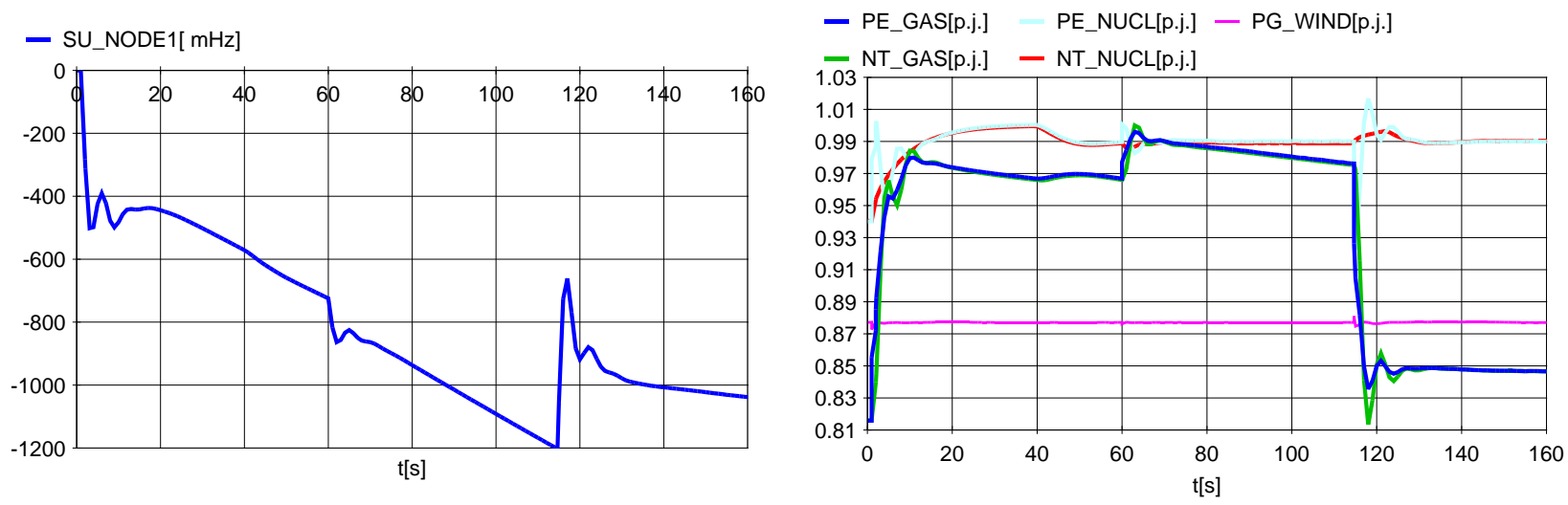

Obr. 6.3-6 Odchylka frekvence sítě (vlevo) a výkony zdrojů (vpravo) pro plynovou turbínu v regulaci výkonu

Regulátor výkonu (bez korekce frekvence) se snaží vrátit výkon turbíny na výchozí hodnotu a její výkon klesá trendem daným zesílením $\mathrm{k}_{\mathrm{I}}$. Po dosažení kritické meze $48.8 \mathrm{~Hz}$ dojde k frekvenčním u odlehčení, po němž se frekvence krátce zotaví, ale po dalším poklesu výkonu turbíny klesá, dokud nedosáhne původní hodnoty nebo se regulátor výkonu nevypne. 


\section{Závěr}

Teoretický výklad základů stability je ve skriptu maximálně zestručněn. Těžiště je přeneseno na řešené příklady, které jsou většinou převzaty z předchozích skript nebo publikací. Jejich řešení je doplněno i počítačovou simulací pomocí programu MODES, který je volně dostupný pro výukové účely.

Pro tři typy stability (úhlovou, frekvenční a napětovou) jsou připraveny i výchozí vzorové projekty, které si čtenář může naimportovat a začít s nimi pracovat podle návodu ve skriptu.

Projekty jsou dostupné na webových stránkách https://www.ueen.fekt.vut.cz/testovacimodely-stabilita-es.

Principy vysvětlení jednotlivých typů stability jsou jednoduché. U statické úhlové stability se definovala výkonová charakteristika $\mathrm{v}$ závislosti na zátěžném úhlu. U dynamické úhlové stability se použilo pravidlo ploch. U frekvenční stability se pracovalo s pohybovou rovnicí. Napětová stabilita se dokumentovala nosovými křivkami, složitějším kritériem $\mathrm{d} \Delta \mathrm{Q} / \mathrm{dU}$ a nakonec i simulací napět’ového kolapsu v časové oblasti s demonstrací reálných faktorů, které přispívají $\mathrm{k}$ jeho vzniku (činnost omezovačů proudů v regulátorech buzení synchronních strojů, lavina napětí způsobená asynchronními motory a automatické přepínání odboček transformátorů).

Jsou uvedeny i simulační výpočty reálných systémových poruch, které ukazují mechanismy jejich vzniku.

Na př́kladu blackoutu Itálie je ukázána zásadní role distančních ochran při ztrátě úhlové stability a rovněž vliv frekvenčního odlehčování zátěže, jako důležitého prostředku bránícího frekvenčnímu kolapsu spolu se schopností zdrojů dodávat výkon při poklesech frekvence.

$\mathrm{Na}$ př́kladu částečného blackoutu Řecka jsou ukázány rizikové faktory napětové nestability, jako je přenos velkých činných výkonů do center spotřeby a nedostatek jalového výkonu. Napět'ová nestabilita je doprovázena i ztrátou úhlové stability s následným vypínáním vedení ochranami (dominový efekt).

Na př́kladu frekvenčního odlehčování ve Velké Británii je ukázána důležitost koordinace výkonové a otáčkové regulace turbín. Rovněž je ukázána role setrvačnosti soustavy, která brání prudkým poklesům frekvence sítě, na které mohou být některá zařízení citlivá. Samotná porucha demonstruje i nedostatečnou schopnost zdrojů odolávat poruchám v síti (typu zkratů), a to nejen těch nesynchronně připojených, ale i konvenčních, jako je paroplynový cyklus, s kterým se počítá jako s perspektivní náhradou za neekologické uhelné zdroje. Proto také pravidla pro připojování nových zdrojů do sítě (stanovené v Nařízení Komise Evropské unie [55]) přesně vymezují podmínky, za jakých musí zůstat zdroje připojeny k síti (i při poruchách spojených s poklesem napětí i změnami frekvence). 


\section{Seznam použité literatury}

[1] Stručný průvodce programu MODES 2.2/7 při analýze dynamického chování ES, [Online] http://www.modesinfo.com/documents/PRUVDEMO.pdf

[2] Kodex PS - část I. Základní podmínky pro uživání přenosové soustavy, [Online] http://www.ceps.cz/cs/kodex-ps

[3] Definition and classification of power system stability, technická brožura CIGRE č. 231, Paříž 2002

[4] K. Máslo: Řízení a stabilita ES, část 4. Systémové služby. [Online] http://home.zcu.cz/ nohac/PJS/MODES/Rizeni_a_stabilita_elektrizacni_soustavy_Cast4.pdf

[5] K. Máslo: Impact of Photovoltaics on Frequency Stability of Power System During Solar Eclipse, IEEE Transactions on power systems, Vol. 31, No. 3, Sept. 2016

[6] K. Máslo, A. Kasembe, Mitigation measures for photovoltaics retrofit, IEEE Transactions on Sustainable Energy, Vol. 9, No. 1, Jan. 2018

[7] Nařízení komise (EU) 2017/1485 ze dne 2. srpna 2017, kterým se stanový rámcový pokyn pro provoz elektroenergetických přenosových soustav, [Online] https://eur-lex.europa.eu/legalcontent/CS/TXT/PDF/?uri=CELEX:32017R1485\&from=CS

[8] K. Máslo: Power system dynamics modeling, $10^{\text {th }}$ International Scientific Conference Control of Power Systems, May 2012

[9] IEC 60909-0:2000, Short circuit current calculation in three - phase AC systems - Part 0: Calculation of currents

[10] Deterministic frequency deviations - root causes and proposals for potential solutions, A joint EURELECTRIC - ENTSO-E response paper, [Online] https://www.entsoe.eu/fileadmin/user_upload/_library/publications/entsoe/120222_Deterministic_Frequency Deviations joint_ENTSOE_Eurelectric_Report_Final_pdf

[11] Kodex PS - část V. Bezpečnost provozu a kvalita na úrovni PS, [Online] http://www.ceps.cz/cs/kodex-ps

[12] Analysis of CE inter-area oscillations of $1^{\text {st }}$ December 2016, ENTSO-E SG SPD Report, 7/2017, [Online] https://docstore.entsoe.eu/Documents/SOC\%20documents/Regional_Groups_Continental_Europe/2017/CE_i nter-area_oscillations_Dec_1st_2016_PUBLIC_V7.pdf

[13] A.M. Ljapunov: Obščaja zadača ob ustojčivosti dviženija, GITTL Moskva 1950

[14] C. P. Steinmetz: Power control,stability of electric generating stations, AIEE Trans., vol. XXXIX, Part II, July 1920 , str. $1215-1287$

[15] AIEE Subcommittee on Interconnections, Stability Factors: First report of power system stability, AIEE Transaction 1926, str. 51-80

[16] S.A. Lebeděv, P.S. Ždanov: Ustojčivost paralelnoj raboty električeskich sistem, GEI Moskva 1934

[17] A.A. Gorev: Vvedenije v těoriju ustojčivosti parlelnoj roboty elktričekich stancij, KUBUC Moskva 1935

[18] V.A. Venikov: Elektromechanické přechodné děje v ES, SNTL Praha 1961

[19] Z. Trojánek, J. Hájek, P. Kvasnica: Přechodné jevy v elektrizačních soustavách, SNTL Alfa 1987

[20] P.M. Anderson, A.A. Fouad: Power System Control,Stability, IEEEPress 1994, ISBN 0-7803-1029-2

[21] P. Kundur: Power System Stability,Control, McGraw-Hill 1994, ISBN 0-07-7035958-X

[22] J. Machowski, J.W.Bialek, J.M. Bumby: Power System Dynamics, John Wiley \&Sons, Ltd, 2008

[23] J. Hájek: Přechodné jevy v elektrizačních soustavách, skriptum VŠSE v Plzni 1983, str.182

[24] M. Hodinka: Přechodné děje v elektrizační soustavě, skriptum VUT Brno,1990

[25] J. Machowski, J.W. Bialek, J.R. Bumby: Power System Dynamics and stability, John Willey \& Sons; 1997

[26] IEEE Committee Report: Excitation System Models for Power System Stability Studies; IEEE PAS No 2; 1981, str. 494

[27] IEC 61970: Energy management system application program interface - Part 302: Common information model (CIM) dynamics, 2018

[28] K. Máslo, A. Kasembe, M. Kolcun: Simplification and Unification of IEEE Standard Models for Excitation Systems, Electric Power Systems Research, No.140, Aug. 2016, str. 132-135

[29] K. Máslo: Posouzení úhlové stability v reálném čase, Energetika č. 5/201/, str. 317 - 320

[30] Ř́zení a stabilita ES, část 3. Analýza ES. [Online] http://home.zcu.cz/ nohac/PJS/MODES/Rizeni_a_stabilita_elektrizacni_soustavy_Cast3.pdf

[31] K. Máslo: Testovací modely pro analýzu stability ES, skriptum FEKT VUT v Brně

[32] P. M. Anderson and A. A. Fouad: Power System Control and Stability, Piscataway, NJ, IEEE/WileyInterscience, 2003 
[33] K. Máslo: Dynamická stabilita a setrvačnost soustavy, Energetika 1/2020, str. 317-322

[34] J. Machowski, J. W. Bialek, J.R. Bumby, Power system dynamic stability and control, $2^{\text {nd }}$ edition 2008, John Wiley \& Sons, Ltd.

[35] H. P. Asal, P. Barth, E. Grebe, D. Quadflieg: Dynamic System Studies of new Requirements, Strategy for the Primary Control in the UCPTE/CENTREL Power System, CIGRE Session, Paris 1998. [Online] https://www.researchgate.net/publication/238768039_Dynamic_System_Studies_of_new_Requirements_and _Strategies_for_the_Primary_Control_in_the_UCPTECENTREL_Power_System_by

[36] Nařízení komise (EU) 2017/2196 ze dne 24. listopadu 2017, kterým se, kodex sítě pro obranu a obnovu elektrizační soustavy, Uřední věstník Evropské unie z 28.11.2017

[37] Modelling of voltage collapse including dynamic phenomena, Technická brožura CIGRE č. 75, 2000, str. 3

[38] Provoz distribučních soustav, ČVUT Praha 2011, [Online] http://doczz.cz/doc/251159/provozdistribu\%C4\%8Dn\%C3\%ADch-soustav---katedra-elektroenergetiky

[39] Technical Analysis of the August 14. 2003, Blackout: Report to the NERC Board of Trustees by the NERC Steering Group, July 13. 2004, [Online]

https://www.nerc.com/pa/rrm/ea/August\%2014\%202003\%20Blackout\%20Investigation\%20DL/NERC_Fina 1_Blackout_Report_07_13 04.pdf 1

[40] S. Larsson, A. Danell: The black-out in southern Sweden and eastern Denmark, 23 September, 2003, IEEE PES Power Systems Conference and Exposition (PSCE '06), 2006

[41] Final report of the Investigation Committee on the 28 September 2003 Blackout in Italy, UCTE Ad-hoc Investigation Committee, April 27. 2004, [Online] https://eepublicdownloads.entsoe.eu/cleandocuments/pre2015/publications/ce/otherreports/20040427_UCTE_IC_Final_report.pdf

[42] C. D. Vournas, V. C. Nikolaidis, A. Tassoulis: Experience from the Athens blackout of July 12, 2004,2005 PowerTech Conference

[43] System disturbance on 4 November 2006, Final report of UCTE, [Online] https://eepublicdownloads.entsoe.eu/clean-documents/pre2015/publications/ce/otherreports/Final-Report20070130.pdf

[44] Arizona-Southern California Outages on September 8, 2011, FERC/NAERC report, April 2012, [Online] https://www.nerc.com/pa/rrm/ea/September\%202011\%20Southwest\%20Blackout\%20Event\%20Document\% 20L/AZOutage_Report_01MAY12.pdf

[45] Report on Blackout in Turkey on 31st March 2015, Final version. 1.0, Sept. 2015, [Online] https://eepublicdownloads.entsoe.eu/cleandocuments/SOC\%20documents/Regional_Groups_Continental_Europe/20150921_Black_Out_Report_v10 w.pdf

[46] Black system event South Australia 28 September 2016, AEMO report, March 2017, [Online] https://www.aemo.com.au/Imedia/Files/Electricity/NEM/Market_Notices_and_Events/Power_System_Incident_Reports/2017/Integrate d-Final-Report-SA-Black-System-28-September-2016.pdf

[47] Interim Report into the Low Frequency Demand Disconnection (LFDD) following Generator Trips and Frequency Excursion on 9 Aug 2019, NationalGridESO report, [Online] https://www.ofgem.gov.uk/system/files/docs/2020/07/national_grid_eso_report_lfdd_9_august_2019.pdf

[48] K. Máslo: Př́činy a následky velkých výpadků v dodávkách elektřiny, Energetika č.7/2005

[49] K. Máslo: Rozpad synchronního propojené sítí UCTE z pohledu dynamické stability elektrizační soustavy, Energetika č.6/2007

[50] Systémové poruchy v elektrizační soustavě - technicko fyzikální pohled, sborník 8. mezinárodní konference Electric Power Engineering (EPE 2007)

[51] K. Máslo: Modelování provozu budoucích Evropských sítí, 21. ročník semináře Aktuální otázky a vybrané problémy ř́zení ES, Poděbrady, květen 2016

[52] Report on 12 July 2004 Blackout in Greece, prepared by Helenic Transmission Operator

[53] K. Maslo, A. Kasembe, S. Moroni, R. Pestana: Frequency stability modelling of the future continental Europe power system, 52 ${ }^{\text {nd }}$ International Universities' Power Engineering Conference (UPEC 2017)

[54] Š. Korčak, T. Hába and K. Máslo: Turbine Control in Island Operation, $21^{\text {th }}$ International scientific conference Electric Power Engineering (EPE 2020)

[55] NAŘÍZENÍ KOMISE (EU) 2016/631 ze dne 14. dubna 2016, kterým se stanoví kodex sítě pro požadavky na připojení výroben $\mathrm{k}$ elektrizační soustavě 


\section{Př́loha 1: základy práce s programem MODES}

Program MODES slouží k simulaci dynamického chování modelu složité elektrizační soustavy. Práci s programem ulehčuje uživatelské rozhraní MODMAN, které umožňuje:

- přistup k vstupním a výstupním datovým souborům a elektronické dokumentaci,

- správu projektů a př́padů,

- spouštění pomocných programů,

- zobrazení nápovědných informací ve stavovém řádku,

- nápovědu kontextovou a bublinkovou (jen do verze WINDOWS XP).

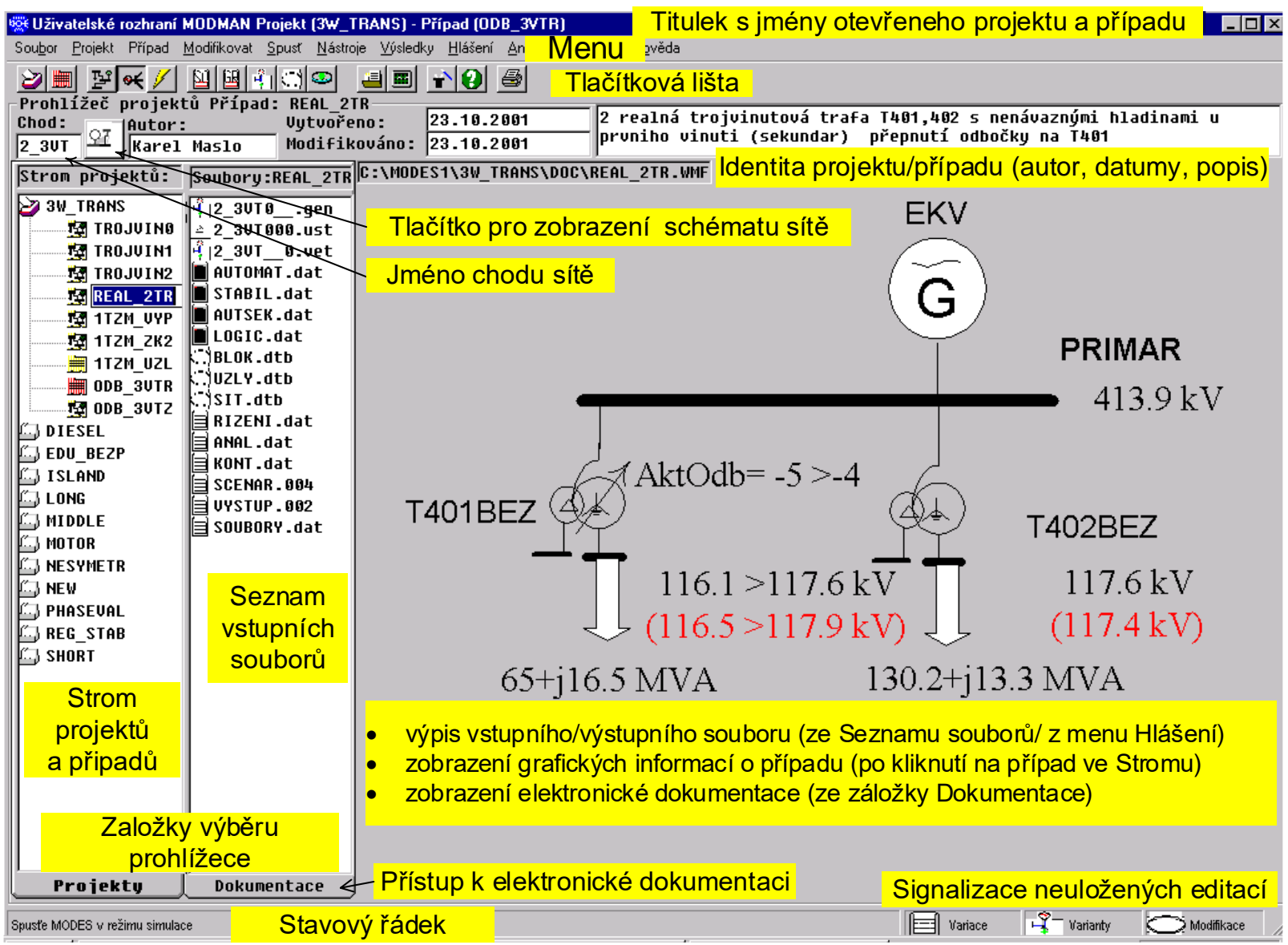

Otevření uživatelského rozhraní se provede dvojitým kliknutím na modrou ikonu MODMAN v průzkumníkovi, správci souborů nebo na pracovní ploše. Tím se dostaneme do uživatelského rozhraní MODMAN (viz obrázek). V levé části je vidět stromová struktura projektů (množina př́ípadů). Po kliknutí na ikonu projektu se rozbalí jednotlivé př́pady ${ }^{1}$. Při procházení stromu se aktualizuje rámeček s identitou projektu nebo př́padu (podle toho, jestli se kliknulo na ikonu projektu nebo př́padu). Při kliknutí na ikonu prŕípadu se zároveň v okně Soubory vypíše sada vstupních souborů daného př́ípadu (uložených ve složce VST pracovního nebo projektového adresáŕ ${ }^{2}$ podle toho, jestli se jedná o otevřený projekt). Kliknutím na jméno souboru se obsah souboru vypíše v pravém textovém okně.

Editace vstupních souborů ${ }^{3}$ se provádí z menu Modifikovat nebo zrychleně z Tlačítkové lišty.

\footnotetext{
${ }^{1}$ Př́ípad představuje sadu vstupních dat, jemuž byla uživatelem přiřazena identita pomocí jména a popisu co řeší

${ }^{2}$ Pracovní je adresář, kde je program nainstalován a odkud je spuštěn MODMAN, projektové adresáře jsou součástí pracovního adresáře (mají stejná jména jako jednotlivé projekty), má dva podadresáře nazvané VST a VYST

${ }^{3}$ Při psaní čísel v textovém režimu je nutno používat jako oddělovač desetinných míst tečku! Přri využívání editorů a dialogů MODMANu je třeba nastavit jako oddělovač tečku v prostředí WINDOWS.
} 
Následující odstavce ukazují postup operací při práci s projekty, př́ípady a vstupními daty.

\section{Otevření projektu:}

- Kliknout na jméno projektu ve sloupci Strom projektů.

- Kliknutím na ikonku $\oslash$ na tlačítkovém pruhu se vybraný projekt otevře, stejný účinek má volba Projekt/Otevrít.

- Stiskem $\boldsymbol{O K}$ se přepíše obsah pracovních podadresářru VST a VYST soubory vybraného projektu a ukáží se případy projektu (ztrátě stávajících dat zabráníte předchozím uložením projektu př́kazy Projekt/Ulož nebo Ulož jako).

1.1. Otevření prŕípadu:

- Vybrat ve sloupci Strom projektů žádaný př́́pad.

- Kliknutím na ikonku se případ otevře (stejný účinek má volba Př́pad/Otevřít) a jeho ikona změní barvu na růžovou.

1.2. Spuštění dynamické simulace se provede kliknutím na ikonku 生. Časový průběh vybraných veličin $v$ jednom, dvou nebo čtyřech grafech je přitom zobrazován v grafice.

1.3. Zobrazení jednotlivých grafů po skončení simulace je možné stisknutím ikonek 目 na Tlačítkové liště.

2. Úprava chodu sítě:

- Kliknout na ikonu $\stackrel{3}{3}$ na tlačítkové liště.

- Kliknout na př́íslušnou tabulku (musí se podbarvit žlutě).

- Pro zadané objekty změníme v tabulkách požadované parametry a skočíme na jiný řádek tabulky (v levém sloupci tabulky v opraveném řádku zmizí př́iznak editace -symbol tužky).

- Stiskneme tlačítko Uložit - objeví se dialog Potvrzení vzniku nové varianty.

- Po stisknutí Ano se změna uloží i do varianty vstupního souboru větví.

- V titulku editoru chodů se objeví nové jméno souboru s chodem sítě.

- Stiskneme tlačítko Přepočítat chod. Po přepočítání se objeví hlášení v textovém okně vpravo dole. Stiskem tlačítka Toky se v tabulce vypíší toky výkonu po vedení.

- Tlačítkem Konec opustíme Editor chodů.

3. Úprava scénáře:

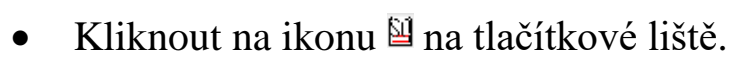

- Stiskněme tlačítko Přidej zásah, v rámečku Typ objektu vybereme potřebný objekt, v Čas se zadá okamžik změny.

- Ve výběrovém boxu Zásah se zvolí potřebný zásah.

- Kliknutím na Přidat objekt se objeví nové okno Výběr objektu, v něm se vybere konkrétní objekt a definují se parametry zásahu.

- Po stisku tlačítek Přidat se objekt uloží a Zruš se okno opustí.

- Kliknutím na Přidat se tento zásah zapíše do scénáře, tlačítkem Zrušit se vrátíme do hlavního okna.

- Zadání časového průběhu scénáře se ukončí tlačítkem $\boldsymbol{O K}$.

- Při volbě Ano na dotaz Vytvořit novou variaci? se vytvoří nová variace datového souboru SCENAR, který má stejné jméno, ale jinou příponu (při volbě $N \boldsymbol{e}$ by se stávající soubor přepsal a nešlo by se $\mathrm{k}$ němu vrátit). 


\section{4. Úprava grafiky:}

- Kliknout na ikonu $\operatorname{Hg}_{\mathrm{g}}$ na tlačítkové liště.

- Stiskněme tlačítko Přidat proměnnou, otevře se okno, kde se vybere typ objektu v rámečku Výběr objektu.

- Ze seznamu Proměnné vybereme potřebnou proměnnou (v Popis proměnné je její popis) a dole v Objekt př́slušný objekt.

- Tlačítky Přidat se proměnná přidá do seznamu (pro každý graf je možno zadat až 7 proměnných) a Zrušit se okno opustí.

- Dole se zaškrtne Chování jako DOS verze.

- Zadání proměnných se ukončí tlačítkem $\boldsymbol{O K}$ - volbou $\boldsymbol{A n o}$ se vytvoří nová variace datového souboru VYSTUP.

5. Úprava parametrů výpočtu:

- Z menu Modifikovat/Ǩizení výpočtu na záložce Dynamic Calculation:

- změníme délku simulačního výpočtu v okně Time of simulation End

- zadáme režim výpočtu mezní doby trvání zkratu zaškrtnutím $\boldsymbol{C C T}$ calculation

- Stiskneme tlačítko $\boldsymbol{O K}$ - volbou $\boldsymbol{A n o}$ se vytvoří nová variace datového souboru RIZENI.

6. Změna typových parametrů modelu bloku:

- Kliknout na ikonu na tlačítkové liště.

- V Seznamu bloki̊ vybereme zadaný blok.

- V rámečku Výběr komponenty stiskneme tlačítko komponenty, do tabulky se nahrají parametry připravených sad v lokálním i globálním katalogu typových parametrů

- Po stisku tlačítka Schéma se objeví blokové schéma modelu. Na spodním řádku se objeví parametry daného modelu bloku a je možné je editovat.

- Stiskem tlačítka Tabulka se provede návrat do tabulky (s potvrzením př́ípadné změny).

- V př́ípadě změny parametrů $\mathrm{v}$ tabulce, je pro uložení změn nutno skočit na jiný ŕádek (aby zmizela editační značka v levém sloupci).

- Tlačítkem $\boldsymbol{O K}$ opustíme Editor a potvrdíme změnu lokálního katalogu typových parametrů.

7. Změna modelu a typových parametrů modelu bloku:

- Kliknout na ikonu na tlačítkové liště.

- V Seznamu bloki̊ vybereme jméno bloku.

- V rámečku Výběr komponenty stiskneme tlačítko komponenty.

- Ze seznamu modelů komponenty vybereme potřebný model.

- Stiskneme tlačítko Vyměnit model a změnu potvrdíme Ano.

- V tabulce Sady typových parametrů klikneme na řádek s vybranou sadou (v levém sloupci se objeví trojúhelník) a stiskneme tlačítko Vyměnit parametry.

- Tlačítkem $\boldsymbol{O K}$ opustíme Editor a potvrdíme vznik nové modifikace modelů bloku.

8. Změna modelu uzlu:

- Kliknout na ikonu na tlačítkové liště

- V Seznamu uzlů vybereme potřebný uzel.

- V rámečku Výběr modelu stiskneme tlačítko vybrané komponenty.

- Stiskneme tlačítko Přidat záznam

- U frekvenčního odlehčování v rámečku Objemy frekvenčního odlehčování navolíme jezdci procentní objemy a stiskneme tlačítko Změnit objem

- Tlačítkem $\boldsymbol{O K}$ opustíme Editor a potvrdíme vznik nové modifikace modelů uzlů.

- V textovém režimu (z menu Modifikovat/Modely uzlů) opravíme počet záznamů $\mathrm{v}$ modifikaci a uložíme. 
9. Uložení př́ípadu a projektu:

Provede se z menu Př́pad/Projekt zvolením Uložit jako a definujeme identitu nového př́ípadu (jméno autora, název a popis případu) tak, aby byl případ co nejlépe dokumentován pro potřeby dalšího použití.

\section{Hlášení programu dostupné z menu Hlášení}

- Inicializace otevře soubor popisující spuštění, s výpisem o chybách při načítání vstupních dat.

- Události informuje o zásazích během výpočtu (dle scénáře, klávesami F1 - F9 nebo činností automatik a logik).

- Změny kroku vypisuje změnu integračního kroku během výpočtu a dobu trvání výpočtu.

- Počáteční podmínky a Inicializace motorů hlášení při inicializaci modelů bloků a asynchronních motorů. 


\section{Př́loha 2: tř́ŕrozměrný model vstupních dat}

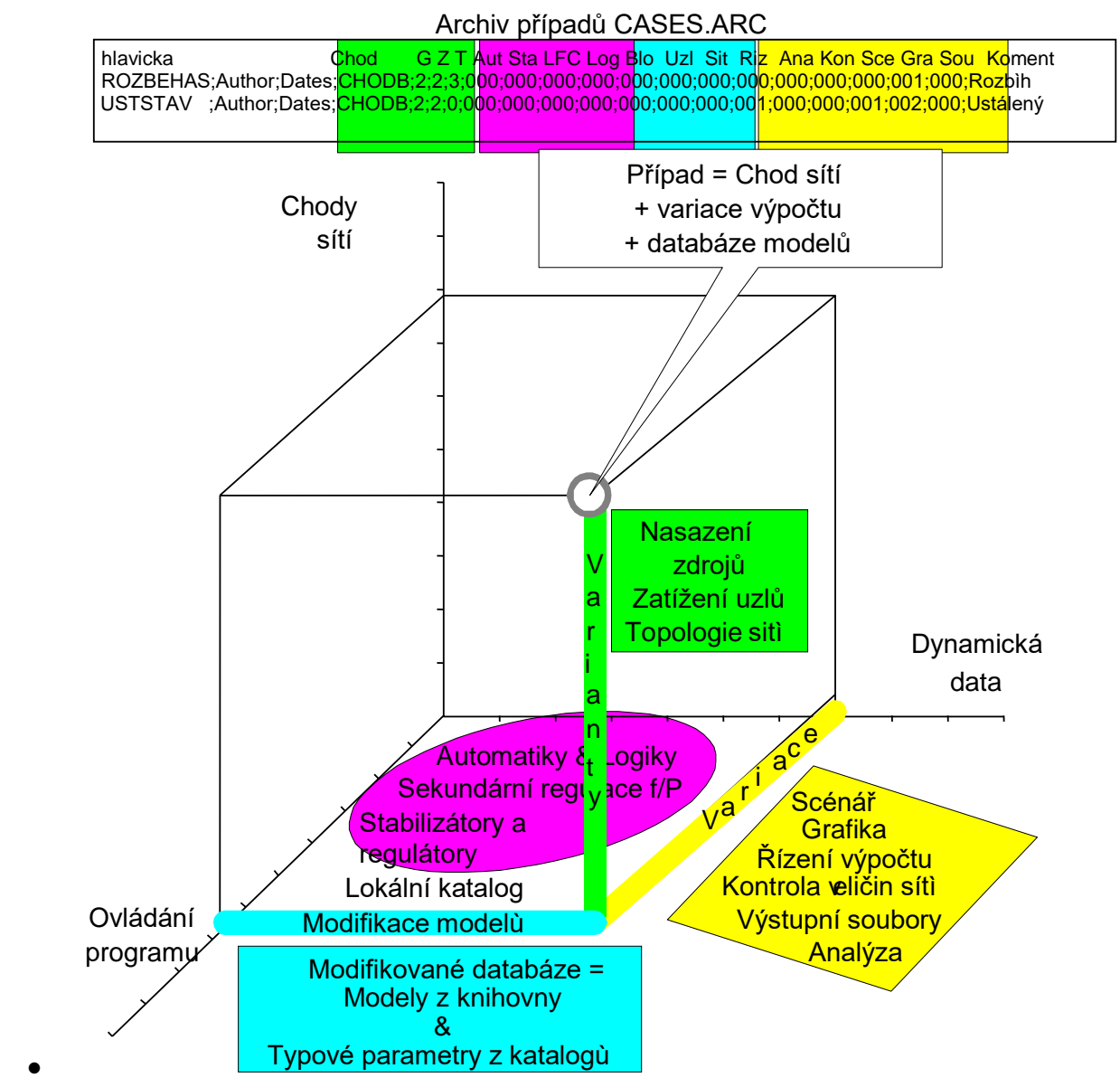

Na svislé ose jsou vyznačeny chody sítě - odpovídající soubory obsahují informace uvedené v zeleném obdélníku. Editací chodů vznikají varianty chodu. Na pravé ose jsou vyznačena data pro dynamiku. Editací databází vznikají modifikace znázorněné azurově. Na pravé ose jsou vyznačeny data pro ovládání programu a jejich editací vznikají variace, znázorněné žlutě. Př́ípad pak tvoří bod $\mathrm{v}$ tř́rozměrném datovém prostoru doplnění vlastní identitou (jménem, specifikací, datem vzniku a poslední změny a jménem toho, kdo je vytvořil) získanou uložením případu př́ikazem Případ| Uložit. Data znázorněná ve fialovém oválu patř́i nadřazeným objektům modelu a lze $\mathrm{z}$ nich vytvářet také varianty $(\mathrm{z}$ menu Modifikovat při zaškrtnuté volbě Vytvořit variaci), Lokální katalog typových parametrů je společný pro všechny př́pady.

Př́pady vznikají editací dat výchozích př́ípadů, po nichž dědí neměněné data a následným uložením. $Z$ tohoto hlediska má každý př́ípad svého rodiče. Je však možno i vytvořit zcela nový př́ípad př́íkazem Př́ípad| Nový. Pak je možno zadat chod sítě bud' ze skladiště odladěných chodů, nebo vybrat kteroukoliv variaci chodu ze stávajícího projektu. Nový př́ípad zdědí výchozí vstupní soubory (s př́íponou $D A T$ ) a základní databázi modelů (s př́íponou $D T B$ ).

Identita př́ípadů je uložena $\mathrm{v}$ archivu př́ípadů CASES.ARC (což je textový soubor uložený ve složce VST) a při otevření př́ípadu se překopíruje do souboru EDIT.ARC, z kterého MODES načítá informace a vstupních souborech otevřeného prŕípadů.

V dalším popisu je uvedena terminologie v souvislosti s názvy jednotlivých položek menu uživatelského rozhraní MODMAN (názvy jsou uvedeny tučným tiskem v uvozovkách). V pracovním adresář́i ${ }^{1}$ se nacházejí v jednotlivých projektových adresárích ${ }^{2}$ vstupní a výstupní soubory vyřešených př́kladů, které jsou v uživatelském rozhraní MODMAN nazývány projekty (,Projekt"). Jména podadresářu jsou totožné se jmény projektů. V rámci jednoho projektu jsou řešeny dílčí problémy nazývané př́pady („Př́ípad“).

\footnotetext{
${ }^{1}$ pracovní adresář, kde je program nainstalován a odkud je spuštěn MODMAN

2 projektový adresář má dva podadresáře nazvané VST a VYST
} 
K jednotlivým př́padům se může uživatel kdykoliv vrátit a výpočet zopakovat. Sada př́ibuzných př́ípadů vytvář́i projekt.

Základní styk uživatele s programem MODES zprostředkuje tzv. grafika („Grafika“), jejíž vzhled lze před spuštěním výpočtu upravit. Časové průběhy vybraných proměnných lze uložit pro pozdější zpracování do uživatelských výstupních souborů („Uživatelské soubory“). Základ modelu tvoří sít' souhrn uzlů (,Uzly“) propojených větvemi („Větve“). Na to navazují synchronní a asynchronní stroje připojené do uzlů (,Bloky“).

Výpočty na dynamickém modelu spočívají v zadání časového sledu zásahů, který nazýváme scénářem (,Scenáŕr"). Na tyto zásahy reagují v programu implementované modely:

- elektrárenských bloků a asynchronních motorů (,Modely bloků“)

- zatížení v uzlech (,Modely uzlü“)

- sít’ových prvků (,Modely sítě“)

- stabilizátorů a regulátorů měřících určitou veličinu a jejich výstup lze připojit do regulátorů buzení a pohonu bloků (,Stabilizátory a Regulátory")

- regulátorů frekvence a předávaných výkonů mezi oblastmi (,Regulace P/f").

Kromě toho může uživatel definovat vlastní modely řídicích a ochranných prvků („Automatiky a ochrany") a logik („Logiky"). Automatika představuje zařízení měřící určitou veličinu a při splnění zadaných podmínek provede vybraný zásah. Logika tvoří nadstavbu automatik a skládá se z logických článků typu součtu nebo součinu. Při splnění logických podmínek provede logika vybraný zásah podobně jako automatika.

Přehled vstupních datových souborů

Následující přehled přiřazuje př́íkazům Modifikovat odpovídající datový soubor, který je modifikován:

Soubory znázorněné bud' v dialogovém režimu nebo textovém (vypnutá volba Modifikovat/Dialogy):

$\begin{array}{ll}\text { Řízení výpočtu } & \text { RIZENI.DAT } \\ \text { Analýza } & \text { ANAL.DAT } \\ \text { Kontrola } & \text { KONT.DAT } \\ \text { Grafika } & \text { VYSTUP.DAT } \\ \text { Scénářr } & \text { SCENAR.DAT } \\ \text { Uživatelské soubory } & \text { SOUBORY.DAT }\end{array}$

Soubory chodu sítěl:

$\begin{array}{ll}\text { Uzly } & \text { UST.DAT } \\ \text { Větve } & \text { VET.DAT } \\ \text { Bloky } & \text { GEN.DAT }\end{array}$

Soubory zobrazované v textovém režimu:

$\begin{array}{ll}\text { Automatiky } & \text { AUTOMAT.DAT } \\ \text { Stabilizátory } & \text { STABIL.DAT } \\ \text { Regulace P/f } & \text { AUTOSEK.DAT } \\ \text { Logiky } & \text { LOGIC.DAT } \\ \text { Seznam symbolů } & \text { SYMBOL.CAT } \\ \text { Modely sítě } & \text { SIT.DTB }\end{array}$

Databáze dynamických modelů bloků a uzlů2:

$\begin{array}{ll}\text { Modely bloků } & \text { BLOK.DTB } \\ \text { Modely uzlů } & \text { UZLY.DTB }\end{array}$

Soubory znázorněné bud' v režimu databázovém nebo textovém (vypnutá volba Modifikovat/Databáze):

$\begin{array}{ll}\text { Katalogy bloků } & \text { TYP_BLOK.CAT a GLOBAL.DAT\TYP_BLOK.CAT } \\ \text { Katalogy sítě } & \text { TYP_SIT.CAT a GLOBAL.DAT \TYP_SIT.CAT }\end{array}$

Katalogy jsou lokální (uloženy ve adresáři VST a dostupné jen danému projektu) a globální (uloženy $\mathrm{v}$ adresáŕi GLOBAL.DAT a dostupné všem projektům)

\footnotetext{
${ }^{1}$ Tyto soubory lze editovat také v Editoru chodů, který je dostupný tlačítkem $\stackrel{\text { Î. }}{\text { naště }}$

${ }^{2}$ Tyto soubory lze editovat také v Editoru modelů, které je dostupná tlačítky
} 